\title{
REGIME JURÍDICO DA ESCRITURAÇÃO EMPRESARIAL NAS SOCIEDADES LIMITADAS E ANÔNIMAS
}

\author{
Trabalho apresentado na Faculdade de Direito \\ da Universidade de São Paulo para a obtenção \\ do título de mestre em Direito Comercial.
}

Orientador:

Prof. Paulo Salvador Frontini.

Faculdade de Direito da USP

São Paulo

2008 
Aos meus pais, José Osvaldo Pereira e Maria Aparecida Marini Pereira, por tudo que dedicaram a minha formação moral $e$ intelectual. À Dirce Alves Benedito, pelo amor e afeto sempre presentes, e pelo incentivo nos momentos difíceis. 


\section{AGRADECIMENTOS}

Várias pessoas mereceriam aqui meu agradecimento. De fato, todos os profissionais da área que se dedicaram a escrever sobre a matéria desbravaram terreno virgem e árido, dele retirando lições e ensinamentos inigualáveis.

Ao meu pai e grande advogado, José Osvaldo Pereira, além de dedicar o presente trabalho, devo agradecer pelo incentivo ao estudo da matéria, bem como pelas lições jurídicas que todos os dias tenho oportunidade de absorver.

Um agradecimento especial devo dedicar ao meu orientador, Prof. Paulo Salvador Frontini, pelas horas dedicadas ao aprimoramento deste trabalho e pelo enriquecimento profissional que me proporcionou.

Estendo meus agradecimentos a todos aqueles que se interessam pelo Direito Comercial, matéria pela qual me apaixono a cada dia. 


\section{RESUMO}

O presente trabalho busca analisar a escrituração empresarial das sociedades anônimas e limitadas. Partindo do reconhecimento da ausência de uma maior exploração do tema em nossa doutrina e da necessidade de atualização e aprofundamento dos escritos já existentes, a pesquisa abarcou desde a natureza jurídica dos processos escriturais, suas espécies e fundamentos, passando pela análise de pontos tradicionalmente fixados pela doutrina, como a distinção entre livros comerciais e fiscais. Buscou-se ainda discutir e aprimorar a interpretação das principais normas contábeis, sob um ponto de vista crítico e atual. Foram abordadas as regras do novo Código Civil (Lei n. 10.406/2002) que, conquanto tenha inovado em matéria de escrituração, recebeu severas críticas doutrinárias, principalmente por adotar regras e princípios de legislações de antanho. Finalmente, foram trazidas as principais consequiências da escrituração nos vários ramos do Direito, além de seus aspectos processuais. Dada a mencionada lacuna doutrinária e jurisprudencial sobre o tema, as dificuldades foram muitas, sendo que em várias passagens este trabalho pretende, com toda a humildade necessária, ser pioneiro, enfrentando os riscos sempre inerentes ao ato de apresentar novos conceitos. 


\begin{abstract}
The present work search to analyze the business bookkeeping of the stock companies and limited liability corporations. Beginning with the recognition of the absence of a larger exploration of the theme in our doctrine and the need of updating and making a profound study of the writings already existent, the research embraced from the juridical nature of the bookkeping processes, their species and foundations, going by the analysis of points traditionally fastened by the doctrine, such as the distinction among books of account and fiscal. It was still looked for to discuss and to perfect the interpretation of the main accounting norms, under a critical and current point of view. The rules of the new Civil Code were approached (Law 10.406/2002) that, although it has innovated as regards to bookkeeping, it received severe doctrinaire critics, mainly for adopting rules and principles of older legislations. Finally, the main consequences of the bookkeeping were brought in the several branches of the Right, besides their procedural aspects. Given her mentioned doctrinaire and jurisprudencial gap on the theme, the difficulties were many, and in several passages this work intends, with all the necessary humility, to be pioneering, facing the risks always inherent of presenting new concepts.
\end{abstract}




\section{SUMÁRIO}

1. TEMA A SER DESENVOLVIDO E SUA JUSTIFICATIVA ..............................................................

2. OBJETIVOS, METODOLOGIA, DELIMITAÇÕES DO TEMA E PRINCIPAIS QUESTÕES A SEREM ANALISADAS

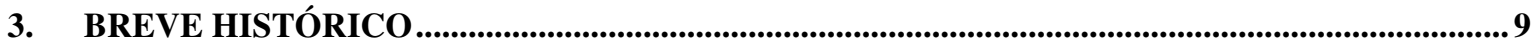

4. CONCEITUAÇÃO DO TEMA E DISTINÇÕES FUNDAMENTAIS .............................................13

5. NATUREZA JURÍDICA DA ESCRITURAÇÃO........................................................................... 18

6. A ESCRITURAÇÃO EMPRESARIAL E SEUS PROCESSOS. REQUISITOS E PRINCÍPIOS CONTÁBEIS GERAIS DA ESCRITURAÇÃ̃O......................................................................................... 28

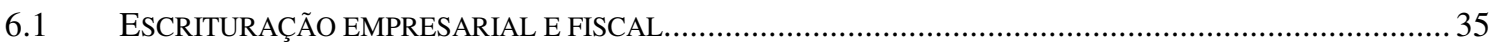

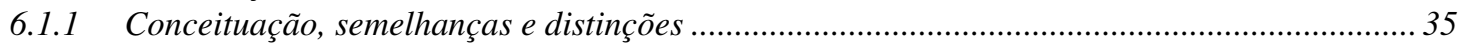

6.1.2 Dispensa de escrituração empresarial pela legislação fiscal..................................................... 41

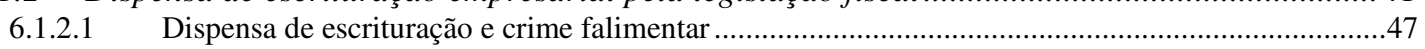

6.1.2.2 Dispensa de escrituração e concordata ou recuperação de empresa ...................................................53

6.1.2.3 Dispensa de escrituração e ações de prestação de contas ou exibição judicial ................................59

6.1.2.4 Dispensa de escrituração e demonstrativos contábeis ..........................................................64

7. A SOCIEDADE LIMITADA E A SOCIEDADE ANÔNIMA ........................................................66

8. ESCRITURAÇÃO NAS SOCIEDADES ANÔNIMAS ......................................................................70

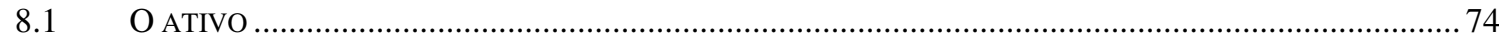

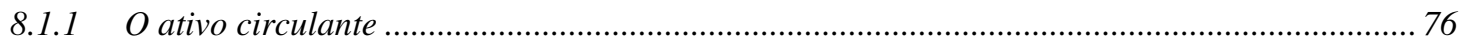

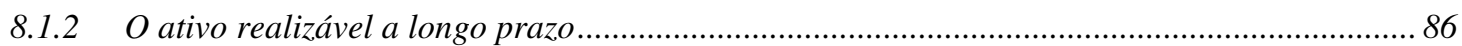

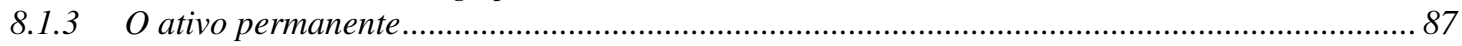

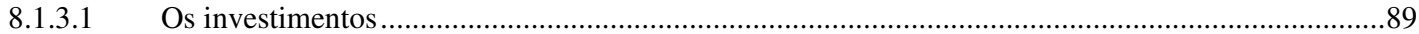

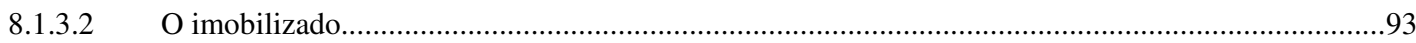

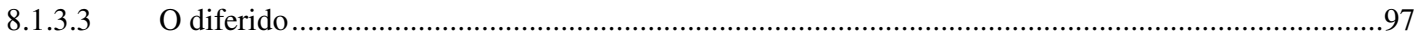

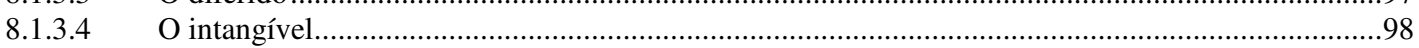

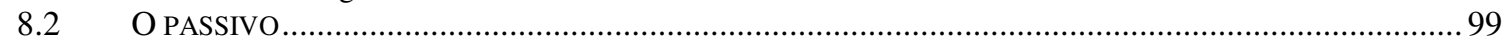

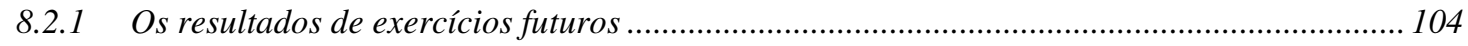

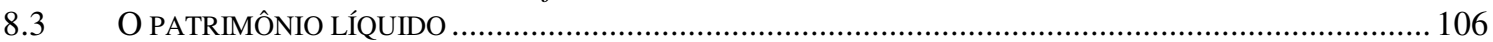

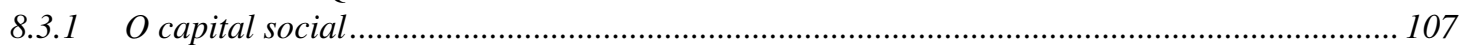

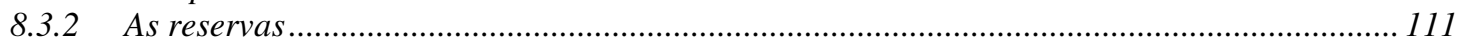

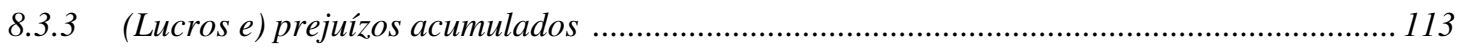

9. A ESCRITURAÇÃO NAS SOCIEDADES LIMITADAS E AS DISPOSIÇÕES DO NOVO

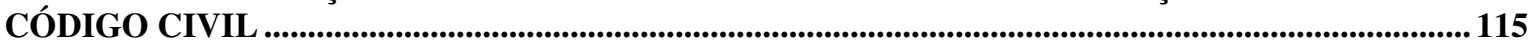

9.1 A ESCRITURAÇÃO DAS SOCIEDADES ANÔNIMAS COMO MODELO PARA AS SOCIEDADES LIMITADAS: APLICAÇÃO SUBSIDIÁRIA DA LEGISLAÇÃO DO ANONIMATO ............................................................... 138

9.2 A ESCRITURAÇÃO NAS MICROEMPRESAS E EMPRESAS DE PEQUENO PORTE .................................. 142

10. OS LIVROS E OS MEIOS ALTERNATIVOS DE ESCRITURAÇÃO ......................................156

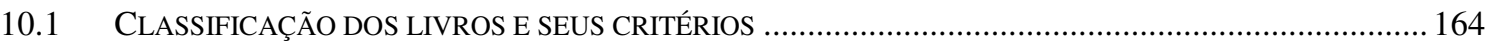

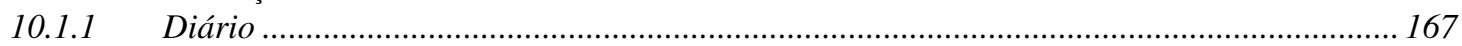

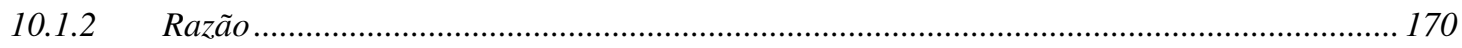

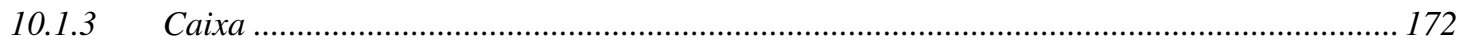

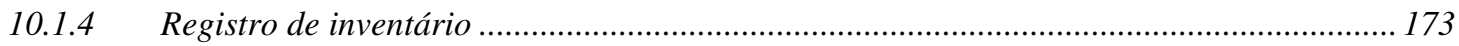

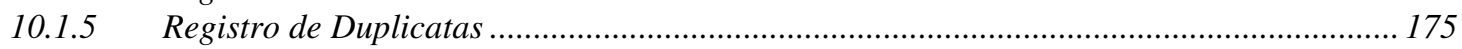




\section{OS EFEITOS IMEDIATOS DA ESCRITURAÇÃO: DEMONSTRAÇÕES CONTÁBEIS E}

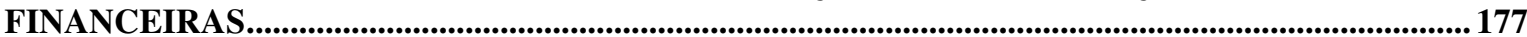

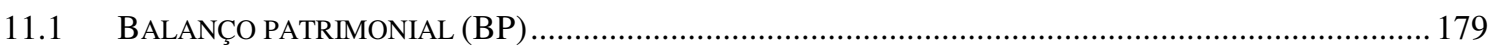

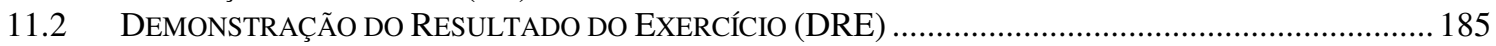

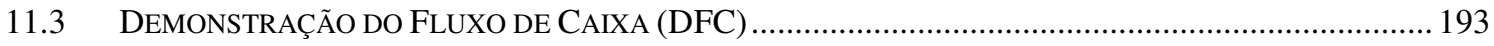

11.4 DEMONSTRAÇÃO DE MUTAÇÕES NO PATRIMÔNIO LÍQUIDO E DE LUCROS E PREJUÍZOS

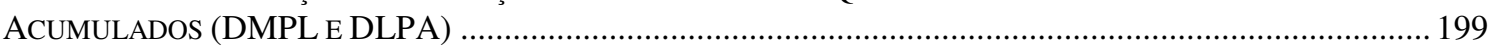

11.5 DEMONSTRAÇÃO DE ORIGENS E APLICAÇÕES DE RECURSOS (DOAR) .......................................203

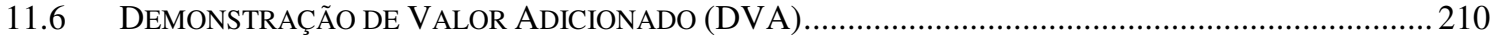

11.7 CORREÇÃO MONETÁRIA DAS DEMONSTRAÇÕES .................................................................... 212

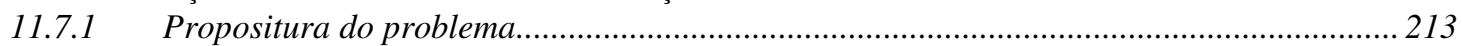

11.7.2 Soluções dadas pela legislação brasileira............................................................................ 214

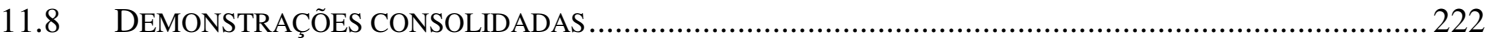

12. REPERCUSSÕES DA ESCRITURAÇÃO, DE SUA AUSÊNCIA OU DEFICIÊNCIA SOB O

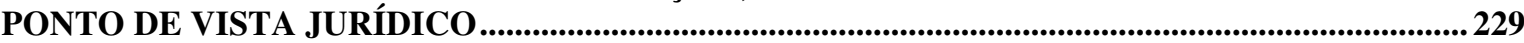

12.1 EFEITOS CIVIS: RESPONSABILIDADE CIVIL DA SOCIEDADE E DO PROFISSIONAL ELABORADOR PELA

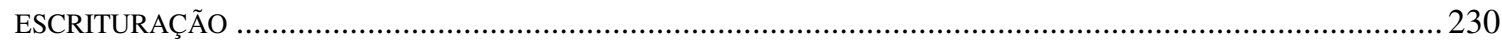

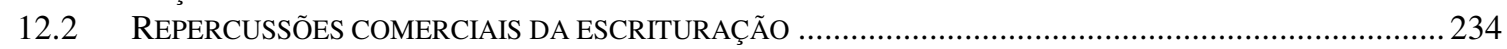

12.2.1 Escrituração e alienação de estabelecimento..................................................................... 234

12.2.2 Sigilo da escrituração e sua necessidade ..................................................................... 236

12.2.3 Regras gerais sobre o sigilo ......................................................................................... 238

12.2.4 Exceções à regra: exibição judicial e administrativa - Autoridades que podem ter acesso à

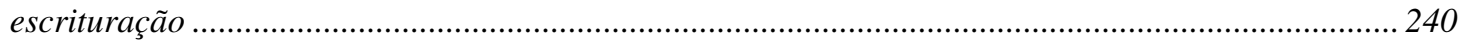

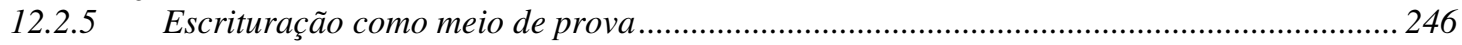

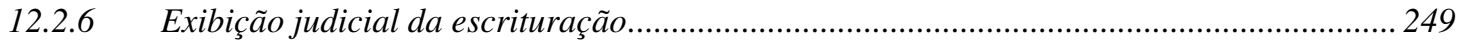

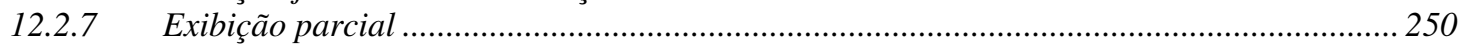

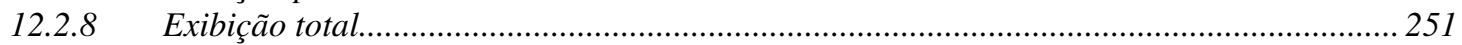

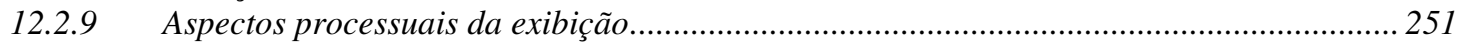

12.2.10 Escrituração e falência.................................................................................................... 252

12.2.11 Escrituração e concordata (recuperação judicial ou extrajudicial) ................................... 255

12.2.12 A escrituração na dissolução de sociedade ....................................................................... 263

12.2.13 Escrituração nas empresas do Novo Mercado e as práticas de boa governança corporativa 266

12.3 IRREGULARIDADE E AUSÊNCIA DE ESCRITURAÇÃO....................................................................2 268

12.3.1 Irregularidade ou omissão por diferença de critérios contábeis e limitação de métodos... 270

12.3.2 Irregularidade por erros e fraudes.............................................................................. 271

12.4 A AUSÊNCIA DE ESCRITURAÇÃO DERIVADA DE EXTRAVIO OU PERDA...........................................2.276

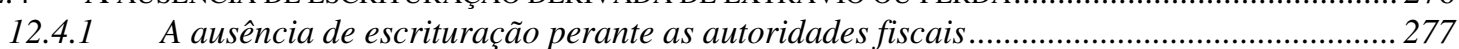

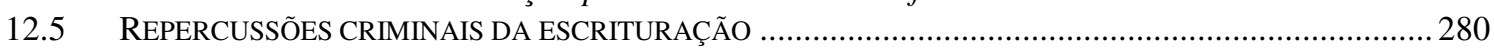

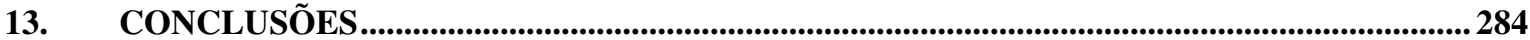




\section{LISTA DE ABREVIATURAS E SIGLAS}

- $\mathrm{BP}$ - Balanço patrimonial;

- CC - Código Civil;

- CP - Código Penal;

- CF, CR ou CF/88 - Constituição Federal, Constituição da República ou Constituição Federal de 1988, respectivamente;

- CLT - Consolidação das Leis do Trabalho;

- DFC - Demonstração de Fluxos de Caixa;

- DJ - Diário da Justiça;

- DLPA - Demonstração de Lucros e Prejuízos Acumulados;

- DMPL - Demonstração de Mutações no Patrimônio Líquido;

- DOAR - Demonstração de Origens e Aplicações de Recursos;

- DRE - Demonstração do Resultado do Exercício;

- DVA - Demonstração de Valor Adicionado;

- FASB - Financial Accounting Standards Board;

- IASB - International Accounting Standards Board;

- IFRS - International Financial Reporting Standards;

- STF - Supremo Tribunal Federal;

- STJ - Superior Tribunal de Justiça;

- TJ - Tribunal de Justiça;

- $\mathrm{TRF}(\mathrm{s})$ - Tribunal(is) Regional(is) Federal(is);

- US GAAP - United States General Accepted Accounting Principles. 


\section{TEMA A SER DESENVOLVIDO E SUA JUSTIFICATIVA}

A escrituração empresarial é, sem dúvida, árdua matéria, que poucos estudos jurídicos têm coragem de aprofundar.

No cotidiano, o tema costuma ser interpretado por muitos como algo que o empresário ou a sociedade empresária delegam aos profissionais de contabilidade (contratados ou terceirizados), sem maiores critérios ou exames. É matéria muitas vezes desacreditada pelos seus aplicadores e destinatários, dado o grande número de fraudes.

Dessa forma, o exame jurídico do assunto, sob o ponto de vista teórico e prático, normalmente não existe ou é perfunctório.

Constata-se facilmente, porém, que a escrituração é o coração do empreendimento. $\mathrm{E}$ isso é tanto mais verdade quanto maior seja a atividade empresarial analisada.

Trata-se de matéria essencialmente regulada pelo Direito e, como tal, objeto de conhecimento do jurista, não devendo este delegar suas atribuições essenciais aos profissionais de ciências correlatas, mas trabalhar em conjunto para atingir melhores resultados.

É necessário, dessa forma, um aprofundamento doutrinário da matéria, necessariamente interdisciplinar. Obviamente, não se deseja aqui formular um manual de técnicas contábeis. Como ressalta Fábio Ulhoa Coelho: "É evidente que o profissional do direito não precisa dominar conhecimentos próprios do contabilista ou do analista de mercado (...) mas ele não pode deixar de apropriar os indispensáveis à aplicação da legislação societária".

\footnotetext{
${ }^{1}$ COELHO, Fábio Ulhoa. Curso de Direito Comercial. São Paulo: Saraiva, 2003. p. 98.
} 
Sabe-se também que a matéria é ainda vista por muitos (juristas ou não) com alguns preconceitos, retirados de uma antiga posição que vislumbrava a escrituração como mero trabalho burocrático dos "guarda-livros".

Superando referidas posições, procurou-se neste trabalho visualizar a escrituração não somente como um processo burocrático, mas como um efetivo sistema de informações empresariais, destinado tanto aos representantes das sociedades empresárias (aqui tratadas as limitadas e as anônimas), como a seus credores e a terceiros interessados.

Buscou-se discorrer sobre os diversos tipos de normas de escrituração impostas pela legislação comercial (em confronto com algumas normas tributárias), seus efeitos imediatos e demonstrações resultantes e suas repercussões no mundo societário.

Além de verificar a essência dos principais processos escriturais, foram analisadas as suas conseqüências teóricas e práticas.

As repercussões jurídicas modernas da escrituração estendem seus efeitos não somente sobre o direito comercial ou empresarial, em matérias como dissolução societária, registro de empresas, autenticação, recuperação judicial e falência. Recaem também sobre o direito tributário (que, imiscuindo-se na matéria comercial, dita na maior parte das vezes o regime de escrituração que a sociedade deve manter e as formas de tributação sobre os valores escriturados), sobre o direito civil (que define as hipóteses de responsabilidade civil profissional) e sobre o direito penal (que define crimes de sonegação de impostos e crimes falimentares derivados de escrituração irregular).

Uma das maiores dificuldades encontradas na elaboração desta dissertação foi a relativa escassez de doutrina sobre a matéria.

Com efeito, grande parte dos trabalhos jurídicos sobre escrituração empresarial limita-se a indicar quais os livros contábeis obrigatórios e facultativos e o âmbito de sua exigência conforme o ramo empresarial. 
Isso causa no jurista um alheamento em relação ao assunto, fazendo-o ser, muitas vezes, mero escriba das instruções dadas por um profissional de contabilidade (técnico ou de nível superior). Tal circunstância, outrossim, impede o exame dos trabalhos periciais elaborados por profissionais nomeados em juízo com maior profundidade, resultando na falta de informação necessária à defesa do interesse que representa ou mesmo ao parecer ou julgamento que irá proferir.

Algumas decorrências práticas dessa situação são efetivamente percebidas no cotidiano forense, entre as quais podem ser mencionadas as mais corriqueiras:

1. Arquivamentos de inquéritos judiciais falimentares, ora sob o argumento de que uma microempresa não necessitaria de escrituração, ora admitindo o cumprimento desta obrigação, uma vez que, pela legislação fiscal (tanto do SIMPLES quanto nas empresas tributadas pelo chamado lucro presumido), torna-se necessária a elaboração de livros caixa e registro de inventário, sob pena de serem submetidas ao regime geral de escrituração empresarial;

2. Magistrados, do mesmo modo, ora exigem, ora dispensam a apresentação nos autos de demonstrações contábeis (balanço patrimonial, demonstrações de resultado, etc.), bem como ora afirmam, ora negam seus efeitos, conforme seu regime de escrituração;

3. Em várias concordatas (hoje, recuperações judiciais), verifica-se que as demonstrações contábeis, em várias oportunidades, permanecem nos autos meramente como peças decorativas, por seu conteúdo não ser compreendido minimamente pelos juristas.

Faz-se necessário, portanto, um maior estudo sobre referida matéria, para aprofundar os conhecimentos jurídicos e uni-los aos detalhes contábeis inerentes.

Outro fator importante que rodeia o tema é a necessidade de retratar as mudanças que ocorreram sob o ponto de vista jurídico na escrituração empresarial. 
De fato, é mister investigar a importância nos dias de hoje, em termos de essência, de algumas distinções realizadas historicamente pela doutrina. Exemplo disso é a tradicional dicotomia entre escrituração comercial (ou empresarial) e fiscal (ou tributária), ou entre livros obrigatórios para alguns ou para todos os tipos de sociedades empresárias.

A legislação fiscal, por sua vez, com freqüência traz exigências de escrituração comercial ou sua dispensa, ingressando em matéria que tradicionalmente não era originariamente seu objeto.

É necessário, portanto, que a doutrina jurídica siga a realidade prática e da moderna legislação, sob pena de restar anacrônica.

Aprofundamento e modernização: eis os motivos e escopos prioritários da presente dissertação. 


\section{OBJETIVOS, METODOLOGIA, DELIMITAÇÕES DO TEMA E PRINCIPAIS QUESTÕES A SEREM ANALISADAS}

Os assuntos delineados no tópico anterior serão desenvolvidos através de algumas linhas de análise.

Procuraremos no início abordar as normas de escrituração inerentes às sociedades anônimas e às limitadas, inserindo na abordagem as referências jurídicocontábeis necessárias.

Referidas sociedades empresariais têm pontos comuns de escrituração, bem como seus aspectos divergentes. Não basta, porém, somente analisar as normas concernentes aos tipos societários, é necessário que se veja como a escrituração influencia outros diplomas legislativos e atividades econômicas e a maneira como recebe a influência deles. Assim, serão vistas algumas das principais repercussões escriturais na legislação falimentar, licitatória, fiscal, processual e penal.

Dada a amplitude do tema, ressaltamos não ser a pretensão deste trabalho esgotá-lo. Por outras palavras: não há aqui o intuito de analisar todas as normas de escrituração existentes sobre os tipos societários antes referidos, nem mesmo de criar um manual sobre a matéria.

Destarte, elabora-se desde já sua primeira delimitação, de modo que não inclua nos objetivos o estudo de aspectos jurídicos da escrituração cuja finalidade seja meramente a memória de dados fáticos, como aquela destinada a conservar dados relativos a ações nominativas de sociedades anônimas, informações inerentes a registros e inspeções do trabalho, atas de assembléias, entre outros. 
Para tanto, acompanha-se aqui a tradicional distinção doutrinária entre escrituração empresarial contábil em sentido estrito e escrituração simplesmente memorial.

A primeira é feita com o objetivo de servir de sistema de informações das operações econômicas da empresa e se opera através de lançamentos de valores em que se utilizam técnicas contábeis propriamente ditas. A segunda serve apenas para registro de fatos ou da prática de atos jurídicos específicos, sem utilização de técnicas contábeis².

Assim, restringiremos nossa pesquisa aos aspectos jurídicos das operações econômicas propriamente ditas, que são objeto da escrituração empresarial de natureza contábil.

Outra delimitação de estudo, já referida, é relacionada com os tipos societários a serem analisados. Com efeito, somente incluiremos neste trabalho o perfil de escrituração empresarial das sociedades anônimas e limitadas.

Saliente-se, porém, que o estudo da escrituração nesses dois tipos societários praticamente abrange a quase-totalidade de referidos processos. A legislação do anonimato, como melhor discutiremos mais adiante, estabelece um verdadeiro manual de escrituração, extensivo às demais sociedades. As limitadas, por sua vez, abrangem os vários tipos societários que adotam sua forma.

Ressalvadas as delimitações acima mencionadas, pretendemos aqui, como objetivo da pesquisa, aprofundar o estudo e conhecimento dos processos escriturais e dos registros contábeis das modernas sociedades, evidenciando não somente sua essência como suas repercussões e trazendo, nas conclusões finais, algumas recomendações sobre a possibilidade de aprimoramento e melhoria das normas vigentes, práticas escriturais e econômicas.

\footnotetext{
${ }^{2}$ A distinção também é feita por Coelho (op. cit., p. 98), nos seguintes termos: "Os livros que os empresários devem possuir, contudo, não são todos contábeis, em sentido estrito. Quer dizer, alguns servem à memória dos valores relacionados às operações de compra e venda, mútuo, liquidação das obrigações, etc. - em síntese, o quanto o empresário deve gastar ou receber, num determinado período. Outros servem à memória de dados fáticos, como o livro de registro de empregados (CLT, art.41) ou o de atas das assembléias gerais (LSA, art. 100, IV), ou à prática de atos jurídicos, como o livro de registro de transferência de ações nominativas (LSA, art. 100, II). Chamem-se os primeiros livros contábeis, e os outros livros simplesmente memoriais".
} 
Subsidiariamente ao escopo principal, através da pesquisa desenvolvida, será possível:

- Explicar, sob o ponto de vista jurídico, o processo de escrituração, evidenciando sua natureza jurídica e finalidades;

- Verificar quais os tipos de escrituração empresarial cabíveis para cada tipo societário analisado no presente trabalho, os respectivos fundamentos das exigências escriturais e as repercussões do tipo societário na escrituração;

- Analisar as relações entre a escrituração empresarial (ou comercial) e a escrituração fiscal, suas interpenetrações e a legislação (com ênfase nas normas que regulam o imposto sobre a renda) que rege cada qual, além das aplicações teóricas e práticas que se percebem;

- Visualizar a relevância jurídica da escrituração empresarial para o sócio, credor e terceiros;

- Demonstrar a distinção entre escrituração e demonstrações financeiras e/ou contábeis e sua relação de causa e efeito;

- Examinar a relevância da distinção doutrinária entre livros obrigatórios para alguns e para todos os empresários;

- Interpretar os dispositivos principais da legislação das sociedades por ações e do Código Civil em relação à escrituração;

- Visualizar as principais conseqüências jurídicas do processo de escrituração, suas repercussões em outros institutos e ramos jurídicos, além dos efeitos de sua irregularidade ou ausência. 
Temos também de restringir os objetivos do presente trabalho à escrituração (e às demonstrações) propriamente dita, de modo que não inclua em seu escopo matérias referentes ao estudo econômico das informações produzidas no processo escritural. Não serão tratados aqui temas inerentes à auditoria de demonstrações ou à análise de seus componentes, ressalvadas algumas pequenas alusões necessárias ao esclarecimento do assunto. 


\section{BREVE HISTÓRICO}

Nos termos da lição de Rubens Requião: “Como é impossível à memória humana reter normalmente a profusão de dados e fatos cotidianos, desde a alta idade média se impôs o costume de registrá-los por escrito"3.

Vê-se, portanto, que a escrituração, antes de um fato inerente à atividade empresarial, é própria da natureza humana, que a utiliza para registrar acontecimentos relevantes, arquivando-os em meios diversos para futura utilização ou referência.

Dessa forma, a escrituração dos fatos relevantes para o comércio nasceu muito antes dos primeiros princípios contábeis que hoje conhecemos. Nesse sentido, o último autor supracitado leciona: “A arqueologia revelou, nas ruínas de templos da Babilônia, tábuas de escrita, onde os sacerdotes registravam as quantidades de cereais, cujos depósitos públicos estavam sob sua guarda. Em Roma, ao pater familias cabia o dever de registrar em livros próprios os negócios de sua atividade econômica e doméstica, usando dois livros: o adversaria, que recebia diariamente o lançamento sumário das operações efetuadas, e o codex accepti et expensi, os quais, ao fim de cada mês, acolhiam, com o histórico respectivo, os assentos que eram ali diligentemente lavrados"

Logo, não é descabido dizer que a escrituração, como processo inerente às necessidades humanas, pode ter precedido até mesmo ao comércio entre os homens, tendo um objeto muito mais amplo que meramente as atividades empresariais, existindo até mesmo naquelas sociedades em que o comércio era incipiente ou mesmo naqueles locais em que era proibido.

É de se verificar que a noção de conta, elemento basilar da contabilidade, remonta também às origens do homem primitivo.

\footnotetext{
${ }^{3}$ REQUIÃO, Rubens. Curso de Direito Comercial. São Paulo: Saraiva, 1991. p. 125.

${ }^{4}$ Op. cit., p. 125-6.
} 
Iudícibus nos relata que "Alguns historiadores fazem remontar aos primeiros sinais objetivos da existência de contas aproximadamente há 4.000 anos a.C. Entretanto, antes disso o homem primitivo, ao inventariar o número de instrumentos de caça e pesca disponíveis, ao contar seus rebanhos, ao contar suas ânforas de bebidas, já estava praticando uma forma rudimentar de Contabilidade ${ }^{\text {,5. }}$

Após o incremento das atividades de troca de mercadorias e o surgimento da moeda, a atividade contábil e a escriturária experimentaram sensível desenvolvimento, que coincidiu em boa parte, sob o aspecto temporal (Idade Média) e espacial (cidades italianas de Veneza, Gênova, Florença Piza e outras), com o desenvolvimento do Direito Comercial como disciplina autônoma.

Atribui-se o crescimento da escrituração empresarial e da ciência da contabilidade, como as conhecemos hoje, à obra pioneira do Frei Luca Pacioli, Tractatus de Computis et Scripturis, inserido na obra maior Summa de Arithmetica, Geometria, Proportioni et Proporcionalità, editada em 1494. Referida obra é conhecida principalmente por revelar o chamado sistema de partidas dobradas, no qual todo e qualquer lançamento envolve simultaneamente débito e crédito de duas ou mais contas.

Além disso, ao sistematizar a ciência contábil e as formas de escrituração, Pacioli inaugura com sua obra a "escola italiana", por alguns denominada "escola européia”. Surge então oportunidade para o aparecimento de outras obras de autores importantes (Cerboni, Zappa, Amaduzzi, etc.).

O período imediatamente posterior à obra de Pacioli é também denominado período científico da contabilidade e é marcado por uma grande evolução científica e pelo aprimoramento durante os séculos posteriores.

Com o surgimento das grandes companhias modernas, principalmente no início do século $\mathrm{XX}$, o desenvolvimento do comércio entre os países e do mercado financeiro e de capitais, passou a predominar a "escola americana" de contabilidade,

\footnotetext{
${ }^{5}$ IUDíCIBUS, Sérgio de. Teoria da Contabilidade. São Paulo: Atlas, 2000. p. 30.
} 
referência feita à doutrina exportada dos Estados Unidos da América, marcada por um reforço teórico sobre auditoria e agências de regulação do mercado, proteção de investidores menores, entre outros temas.

No Brasil, houve grande influência da escola italiana e européia, muito embora tenhamos sofrido ingerência mais recente da escola americana ${ }^{6}$.

O Código Comercial de 1850 continha vários dispositivos sobre escrituração comercial.

$\mathrm{O}$ art. 10 de referido diploma dispunha que todos os comerciantes são obrigados:

1 - a seguir uma ordem uniforme de contabilidade e escrituração, e a ter os livros para esse fim necessários;

2 - a fazer registrar no Registro do Comércio todos os documentos, cujo registro for expressamente exigido por este Código, dentro de 15 (quinze) dias úteis da data dos mesmos documentos (artigo $n^{o}$. 31), se maior ou menor prazo se não achar marcado neste Código;

3 - a conservar em boa guarda toda a escrituração, correspondências $e$ mais papéis pertencentes ao giro do seu comércio, enquanto não prescreverem as ações que lhes possam ser relativas (Título XVII);

4 - a formar anualmente um balanço geral do seu ativo e passivo, o qual deverá compreender todos os bens de raiz móveis e semoventes, mercadorias, dinheiro, papéis de crédito, e outra qualquer espécie de valores, e bem assim todas as dívidas e obrigações passivas; e será datado e assinado pelo comerciante a quem pertencer.

\footnotetext{
${ }^{6}$ Apontam-se como exemplos de influências da escola americana os diversos institutos destinados a proporcionar informação e proteção ao pequeno investidor, tais como a ingerência de órgãos governamentais (CVM) nas normas referentes às demonstrações contábeis e a necessidade de auditoria externa (art. 177, $\S 3^{\circ}$, da Lei n. 6.404/76).
} 
Obrigava ainda o Código a manutenção dos livros Diário e Copiador de Cartas. Em seu art. 14, determinava que a escrituração desses livros deveria ser feita em forma mercantil, e seguida pela ordem cronológica de dia, mês e ano, sem intervalo em branco, nem entrelinhas, bordaduras, raspaduras ou emendas, além de determinar normas de sigilo e exibição.

Outras normas foram baixadas em complementação ao Código Comercial, no que diz respeito à escrituração. Como exemplo, temos o Dec.-Lei n. 486, de 3 de março de 1969, regulamentado pelo Dec.-Lei n. 64.567, de 22 de maio de 1969.

Entre as principais medidas do Dec.-Lei n. 486 estão: 1) abolição da obrigatoriedade do livro copiador de cartas; 2) dispensa de escrituração pelos pequenos comerciantes $^{7}$, 3) possibilidade de adoção de fichas em substituição ao Diário, para os comerciantes que empregassem escrituração mecanizada.

A Lei n. 6.404/76 (Lei das Sociedades por Ações) dedicou seu capítulo XV ao exercício social e às demonstrações financeiras, incluindo nele diversas normas sobre escrituração.

Finalmente, o novo Código Civil (Lei n. 10.406, de 10 de janeiro de 2002) também disciplinou o assunto no Capítulo IV, Título IV, Livro III de sua Parte Especial, revogando expressamente a parte primeira do Código Comercial de 1850.

Hoje a escrituração empresarial é ainda regulada por diversas normas infralegais de natureza fiscal e comercial (provindas de órgãos públicos como a Comissão de Valores Mobiliários - CVM).

\footnotetext{
${ }^{7}$ Considerava-se pequeno comerciante, para os efeitos do parágrafo único do art. $1^{\circ}$ do Decreto-lei n. 486, de 3 de março de 1969, a pessoa natural inscrita no registro do comércio: I - Que exercesse em um só estabelecimento atividade artesanal ou outra atividade em que predomine o seu próprio trabalho ou de pessoas da família, respeitados os limites estabelecidos no inciso seguinte; II - Que auferisse receita bruta anual não superior a cem (100) vezes o maior salário mínimo mensal vigente no país e cujo capital efetivamente empregado no negócio não ultrapassar vinte (20) vezes o valor daquele salário mínimo.
} 


\section{CONCEITUAÇÃO DO TEMA E DISTINÇÕES FUNDAMENTAIS}

Várias são as concepções do termo escrituração. De acordo com o dicionário Aurélio $^{8}$, tem-se como escrituração o seguinte:

1. Ato de escriturar nos livros competentes os fatos administrativos duma azienda. 2. O conjunto dos livros e registros de contabilidade duma azienda. 3. Arte de os escriturar.

Ainda a mesma obra conceitua como escrituração mercantil " $a$ contabilidade praticada, segundo métodos usuais, nas empresas mercantis”.

Alguns doutrinadores, restringindo alguns conceitos, fazem uma separação entre os termos contabilidade e escrituração.

Nos termos da lição de Fran Martins: "Por contabilidade deve-se entender a ciência que tem por finalidade a orientação e o controle dos atos e feitos de uma administração econômica. A escrituração é a redução a escrito das operações contábeis, ou seja, a fixação metódica, nos livros apropriados, das operações efetuadas pelo comerciante. Os dois termos são, às vezes, confundidos na prática, mas, como esclarece Waldemar Ferreira, a contabilidade é o gênero e a escrituração é a espécie"”.

Dessa forma, na acepção do ilustre doutrinador citado, a contabilidade, como ciência, ocupar-se-ia dos princípios, postulados e regras gerais, enquanto a escrituração se limitaria à atividade mecânica que, seguindo os princípios contábeis, teria a função de materializar os fatos econômicos inerentes à atividade empresarial.

\footnotetext{
${ }^{8}$ Novo Dicionário Aurélio da Língua Portuguesa. Curitiba: Editora Positivo. 1 CD-ROM.

${ }^{9}$ MARTINS, Fran. Curso de Direito Comercial. Rio de Janeiro: Forense, 1990. p. 114-5.
} 
Entretanto, a disposição da legislação nacional, em relação às sociedades anônimas (Lei n. 6.404/76) e limitadas (Código Civil), parece ter entendido justamente o contrário da distinção doutrinária mencionada, ao inserir a contabilidade como meio em relação ao todo maior constituído pela escrituração.

Veja-se que a primeira das legislações acima citadas traz, no tratamento da matéria, o capítulo denominado "Escrituração", representando o objeto de que aqui se cuida, para, no interior deste (art. 177), inserir que “A escrituração da companhia será mantida em registros permanentes, com obediência aos preceitos da legislação comercial e desta Lei e aos princípios de contabilidade geralmente aceitos, devendo observar métodos ou critérios contábeis uniformes no tempo e registrar as mutações patrimoniais segundo o regime de competência" (grifos nossos).

O Código Civil também partiu para a mesma linha, ao definir no Capítulo IV, Título IV, o objeto de normatização como sendo "Da Escrituraçãa", delimitando seus detalhes no art. 1.179, verbis: "O empresário e a sociedade empresária são obrigados a seguir um sistema de contabilidade, mecanizado ou não, com base na escrituração uniforme de seus livros, em correspondência com a documentação respectiva, e a levantar anualmente o balanço patrimonial e o de resultado econômico” (grifos nossos).

Por outras palavras, nos termos dispostos na legislação, a utilização da contabilidade, como ciência, e de seus princípios, foi colocada como o meio ou espécie para a realização do objeto principal, qual seja, a escrituração.

Para melhor estabelecermos essa relação e sabermos se a contabilidade ou a escrituração se conceituarão, cada qual, como gênero ou espécie (ou se referida relação sequer se estabelecerá), estabeleceremos que, em um primeiro momento, os temas podem ser conceituados, no mínimo, sob um ponto de vista amplo e outro restrito, estabelecidos em diversos graus, conforme variarem seus objetos e abrangências.

$\mathrm{Na}$ acepção mais ampla, a escrituração abrangeria tanto a prática de registros econômicos (e não econômicos) em meios apropriados (livros, documentos, fichas ou meios eletrônicos) quanto os princípios, postulados e normas necessárias à referida atividade, inerentes à contabilidade e outros postulados de ciências correlatas. 
Engloba-se, aqui, a escrituração de todos os fatos relevantes na administração de uma empresa, sejam eles contábeis ou não.

Numa outra conceituação, adotada pela doutrina acima mencionada, a escrituração abarcaria tão-somente a atividade material de realização de lançamentos contábeis, ficando a metodologia fora de sua conceituação, por ser abrangida pela ciência da contabilidade.

Preferimos adotar aqui a conceituação de escrituração mais ampla, que abrange a escrituração contábil e aquela de natureza não contábil (da qual não trataremos neste trabalho).

Com efeito, não podemos dizer que toda escrituração tem natureza contábil. Conforme salientamos anteriormente, existe uma ampla gama de fatos que devem ser escriturados, sem utilização dos princípios e postulados da contabilidade, como os registros inseridos em livros de empregados, registros de ações nominativas, atas de assembléias, entre outros. Trata-se, pois, do que se chama de escrituração simplesmente memorial, que serve apenas para registro de fatos ou da prática de atos jurídicos específicos.

Assim, dizer que a contabilidade é gênero no qual a espécie (escrituração) está necessariamente inserida deixa fora deste objeto a escrituração memorial, que se consubstancia em escrituração de fatos não avaliados em moeda e sem a utilização dos princípios e rigores contábeis.

Preferimos dizer, portanto, que a escrituração tem com a contabilidade um campo em comum: escrituração empresarial (contábil) das atividades passíveis de avaliação econômica e pecuniária; possuindo também seus pontos de distanciamento ou divergência: a escrituração simplesmente memorial.

Assim, não se estabelece, em nosso entender, qualquer relação de meio-fim, ou gênero-espécie entre ambas.

A contabilidade, como ciência, busca, através de uma série de princípios, postulados e regras, disciplinar a elaboração de um sistema de informações empresariais 
envolvendo fatos econômica e monetariamente apreciáveis. A escrituração, por seu turno, como atividade prática, visa a evidenciar ou dar ciência, por diversos meios, dos eventos empresariais relevantes, sejam eles passíveis ou não de apreciação contábil.

Por esse motivo, concordamos integralmente com a opinião de J. X. Carvalho de Mendonça, para quem os dois conceitos (escrituração e contabilidade) restam bem distintos, não possuindo relações de meio-fim ou gênero-espécie: "A palavra contabilidade costuma ser empregada no mesmo sentido de escrituração, conforme o uso mercantil (Ferreira Borges, Dicc. Jurídico, verb. Contabilidade). Este vocábulo (contabilidade) é genuinamente português e significa: receita e despesa de uma casa comercial; a arte de arrumar os livros comerciais. Consulte-se Aulete, Dicionário Contemporâneo. Certo é, porém, que se não deve confundir a contabilidade com a escrituração mercantil: aquela é uma ciência, tendo por objeto a organização dos livros e o estabelecimento das contas relativas aos produtos do trabalho e às transformações do capital, ou, mais brevemente, à ciência do cálculo aplicada aos negócios; esta, uma arte, tendo por objeto o lançamento ou registro metódico das operações comerciais, de acordo com os princípios da contabilidade ou ciência das contas. Esta distinção é bem explicada por Léautev \& Gilbault, no Traité Théorique et Pratique de Comptabilité (págs. 5 a 24), depois de criticar inúmeras definições que de contabilidade (comptabilité) e escrituração (tênue des livres) deram os autores" ${ }^{\prime \prime}$.

Em suma: a escrituração poderá ou não atuar em conjunto com a contabilidade. Assim será, apenas quando aproveitar-se dos conhecimentos desta ciência para efetivar sua tarefa. Nos demais casos, será simplesmente destinada ao registro de fatos não econômicos, do que não trataremos aqui.

Como trataremos mais adiante, é importante antecipar neste momento que também não se confundem escrituração e demonstrações financeiras ou contábeis. Na verdade, a primeira é fonte das segundas, servindo-lhe de base. As demonstrações apenas visam a sintetizar, organizar e estruturar, para fins de entendimento dos usuários do sistema contábil empresarial, o que anteriormente já fora inserido na escrituração.

\footnotetext{
${ }^{10}$ MENDONÇA, José Xavier Carvalho de. Dos livros dos comerciantes. São Paulo: Rothschild, 1906. p. 1.
} 
Por outras palavras, ocorrido o fato econômico, passa-se ao processo de escrituração que é evidenciado interna ou externamente através das demonstrações contábeis. 


\section{NATUREZA JURÍDICA DA ESCRITURAÇÃO}

Juridicamente, a escrituração empresarial não tem existência própria, desvinculada do ato jurídico que lhe deu base ou fundamento. De fato, não há sentido em escriturar sem que haja um substrato jurídico que lhe dê origem e lastro.

Dessa forma, a atividade escritural é necessariamente acessória de outros atos jurídicos que ensejam a realização desse processo, vinculando-se à externalização ou formalização do negócio jurídico inerente.

Como se sabe, um determinado ato ou negócio jurídico pode vir ao conhecimento dos sujeitos que os praticam ou de terceiros por diversos meios: escrito (contratual, cambiário, registrário, etc.), verbal (o que costuma ocorrer nos atos de pequena monta, como doações, vendas e pequenas prestações de serviço etc.), gestual (mais comum em leilões), entre outros mais.

Nesse sentido, a escrituração empresarial é apenas uma das formas conhecidas para que determinado negócio jurídico tenha forma e roupagem jurídica necessária.

Isso é verificável facilmente quando vislumbramos as normas que regem os efeitos probatórios dos livros empresariais obrigatórios, as quais dispõem que estes poderão provar a favor do empresário (quando corretamente escriturados) e contra este (mesmo que incorretamente escriturados).

O efeito probatório aludido por tais normas tem por objeto nada mais do que o próprio negócio jurídico empresarial, cuja forma de externalização foi a escrituração em livro. Assim, as partes que firmam entre si um negócio jurídico, se não tiverem restrições legais quanto à forma, poderão optar por várias entre as permitidas ou não vedadas no ordenamento jurídico. 
Como exemplo, dois empresários que desejam pactuar um empréstimo (contrato de mútuo) poderão fazê-lo por diversas maneiras, entre as quais se incluem: 1) através de um contrato escrito entre ambos, que preveja as obrigações das partes, por escritura pública ou particular, registrada ou não em cartório; 2) por meio de um contrato verbal; 3) através da emissão de uma nota promissória pelo devedor em favor do credor; 4) pela inserção, no livro Diário do credor, de um lançamento contábil que consigne a saída do dinheiro do empréstimo, com o crédito correspondente em seu ativo e o conseqüente lançamento no livro Diário do devedor da entrada do dinheiro e reconhecimento de uma obrigação em seu passivo.

Qualquer uma das maneiras acima aludidas será juridicamente apta para que o negócio jurídico se aperfeiçoe e produza seus efeitos. Caso optassem as partes pela formalização do negócio através da inserção de lançamentos nos livros contábeis (opção 4, supracitada), poderia ser obtido em juízo, no caso de inadimplemento da obrigação, praticamente o mesmo reconhecimento e conseqüente cumprimento coativo do vínculo obrigacional que aquele cabível nas demais opções supracitadas ${ }^{11}$.

Conclui-se, portanto, que a escrituração está inserida na disciplina da forma dos atos e negócios jurídicos empresariais, servindo como meio de publicidade e de prova da prática destes.

Como consequiência, podemos concluir que as normas que tratam do assunto escritural, nos diversos diplomas esparsos, constituem-se, na verdade, numa especialização daquelas contidas, nos dias atuais, no Título V, do Livro III da Parte Geral do Código Civil, que trata da prova dos negócios jurídicos. Evidência disso é a inserção do art. 226 no tópico aludido, com a seguinte redação:

\footnotetext{
${ }^{11}$ Desprezam-se aqui algumas peculiaridades referentes aos trâmites processuais. Obviamente, a promissória e o contrato (este se subscrito por duas testemunhas), como títulos executivos, proporcionariam ao credor as facilidades de independer de um prévio processo de conhecimento para a cobrança de sua dívida, o que não ocorreria com a formalização através de lançamento contábil, que não é reconhecido como título executivo pelo Código de Processo Civil.
} 
Art. 226. Os livros e fichas dos empresários e sociedades provam contra as pessoas a que pertencem, e, em seu favor, quando, escriturados sem vício extrínseco ou intrínseco, forem confirmados por outros subsídios.

Parágrafo único. A prova resultante dos livros e fichas não é bastante nos casos em que a lei exige escritura pública, ou escrito particular revestido de requisitos especiais, e pode ser ilidida pela comprovação da falsidade ou inexatidão dos lançamentos.

Mas constatar que a escrituração comunga a natureza jurídica de formalização ou meio de prova de negócios jurídicos empresariais é ainda dizer pouco. É mister que prossigamos nessa análise para verificar que tipo de formalidade temos quando determinado negócio jurídico é escriturado, bem como quais são seus efeitos.

Muito embora com certa divergência, a doutrina costuma classificar a forma dos atos jurídicos em dois tipos: 1) ad substantiam ou ad solemnitatem, formas internas, intrínsecas ao ato jurídico respectivo; 2) ad probationem, ou externas. As primeiras serviriam à perfeição e ao acabamento dos atos jurídicos e as segundas à sua prova ${ }^{12}$.

Por outro lado, como bem explicita Pontes de Miranda: “A forma pode ser pressuposto de existência do ato jurídico, de eficácia ou de validade. A doação verbal de bem imóvel não é nula; é inexistente. A doação verbal de bem móvel sem lhe seguir, desde logo, a tradição, também o é. A doação de bem imóvel por instrumento particular é nula, porque não se observou o art. 134, II. A forma pode ser elemento necessário ao suporte fático para que entre no mundo jurídico, ou para que o ato jurídico valha, ou para que o ato jurídico tenha certo efeito, ou certos efeitos" ${ }^{\prime 13}$.

Diante do que até aqui se expôs, cabe resolver as seguintes indagações:

\footnotetext{
${ }^{12}$ A distinção é referida por GOMES, Orlando. Introdução ao Direito Civil. Rio de Janeiro: Forense, 1990, p. 396. O próprio autor citado e boa parte da doutrina não vêem mais razão para a distinção entre as duas espécies de forma, preferindo meramente classificar os atos jurídicos, quanto à forma, simplesmente em solenes e não solenes. Mantivemos a distinção referida no texto para que se viabilizasse a discussão ampla da matéria.

${ }^{13}$ MIRANDA, Pontes de. Tratado de Direito Privado. São Paulo: Revista dos Tribunais, 1983. p. 347.
} 
1) A escrituração será formalidade sempre "ad probationem” ou poderá ser da substância do ato ("ad substantiam”)?

2) Omisso o empresário em escriturar determinado ato praticado, poderá vir este a ser declarado inexistente, inválido ou ineficaz? Escriturando corretamente determinado negócio, qual a eficácia que o ordenamento jurídico emprestará a referida materialização?

A resposta às questões acima formuladas comporta diversas considerações e certamente não admite solução única.

Casos há - e constituem maioria - em que a escrituração, como forma pela qual determinado negócio jurídico se revela, será meramente “ad probationem”.

Nossa legislação, aliás, está totalmente voltada à compreensão e discussão dos processos escriturais sob o ponto de vista dos efeitos de prova, condicionando o intérprete a considerá-la apenas sob o ponto de vista da forma "ad probationem". Menciona-se em nosso ordenamento tão-somente se os livros empresariais têm efeito de prova contra ou a favor do comerciante e em quais tipos de litígio referida prova pode ser utilizada.

Para que se constate tal fenômeno, basta analisarmos o art. 226 do Código Civil supracitado, o art. 20 do antigo Código Comercial e os arts. 378 a 380 do Código de Processo Civil, que ora transcrevemos:

Art. 20 - Se algum comerciante recusar apresentar os seus livros quando judicialmente lhe for ordenado, nos casos do artigo $n^{o}$. 18, será compelido à sua apresentação debaixo de prisão, e nos casos do artigo $n^{o} .19$ será deferido juramento supletório à outra parte. Se a questão for entre comerciantes, dar-se-á plena fé aos livros do comerciante a favor de quem se ordenar a exibição, se forem apresentados em forma regular (artigo $n^{o} s$ 13 e 14). 
Art. 378 - Os livros comerciais provam contra o seu autor. É lícito ao comerciante, todavia, demonstrar, por todos os meios permitidos em direito, que os lançamentos não correspondem à verdade dos fatos.

Art. 379 - Os livros comerciais, que preencham os requisitos exigidos por lei, provam também a favor do seu autor no litígio entre comerciantes.

Art. 380 - A escrituração contábil é indivisível: se dos fatos que resultam dos lançamentos, uns são favoráveis ao interesse de seu autor e outros lhe são contrários, ambos serão considerados em conjunto como unidade.

Talvez o legislador tenha seguido tal caminho pela observância prática de que a tendência normal, oriunda daquilo que ordinariamente ocorre, é que se reserve à escrituração apenas um papel de prova relativa do negócio jurídico por ela representado.

De acordo com a legislação anteriormente mencionada - e aqui temos a regra -, a escrituração terá as seguintes características:

1) Será meramente um meio de prova, como forma "ad probationem", não influenciando nos aspectos intrínsecos do negócio jurídico respectivo e, portanto, não se constituindo em forma interna ou "ad substantiam";

2) Configurar-se-á em prova relativa, podendo ser superada por outros elementos de prova (testemunhal, documental e pericial) que evidenciem que a escrituração não corresponde à verdade dos fatos;

3) Não poderá substituir outros tipos de forma, prescritas pela legislação como essenciais a determinados atos ou negócios jurídicos. Assim, v.g., não poderá um empresário, através de lançamento em seu ativo imobilizado e correspondente diminuição do ativo circulante, suprir a escritura pública destinada à formalização da compra de um determinado imóvel. 
No entanto, por vezes a escrituração poderá se constituir em prova ad substantiam e influir decisivamente no plano da existência de um negócio jurídico.

Tomemos como exemplo, inicialmente, os negócios que, nos dias de hoje, têm sua existência dependendo da escrituração.

Veja-se, nesse sentido, o caso das ações escriturais de sociedades anônimas, cuja transferência depende de um lançamento contábil na escrita da(s) entidade(s) incumbida(s) de tal tarefa pelas companhias e respectivos acionistas. Ausente a escrituração, certamente não haverá negócio jurídico subjacente, evidenciando ser a escrituração, no caso, elemento essencial ou de substância do negócio ${ }^{14}$.

Do mesmo modo, a distribuição de lucros ou dividendos, antecipadamente ao fim do exercício, nos seguintes termos: antes do encerramento do exercício (normalmente coincidente com o ano civil), determinada sociedade empresária decide distribuir dividendos ou lucros para seus sócios, sem que venha a evidenciar seu montante através de demonstrações contábeis regulares, no caso o balanço patrimonial (BP) e a demonstração de resultado do exercício (DRE).

Pressupomos aqui que não exista fraude, ou seja, que o lucro efetivamente existiria se contabilizado nas formas regulares, não estando a sociedade, portanto, distribuindo outras parcelas de seu patrimônio líquido, como o capital ou as reservas societárias.

Distribuído regularmente, com a devida escrituração e conseqüentes demonstrações, o lucro (ainda que antecipado) é parcela que, nos dias de hoje, resta isenta de qualquer tributação em relação ao imposto de renda ou contribuições sociais ${ }^{15}$.

\footnotetext{
${ }^{14}$ Previsão legal no art. $35, \S 1^{\circ}$, da Lei n. 6.404/76, segundo o qual: "A transferência da ação escritural opera-se pelo lançamento efetuado pela instituição depositária em seus livros, a débito da conta de ações do alienante e a crédito da conta de ações do adquirente, à vista de ordem escrita do alienante, ou de autorização ou ordem judicial, em documento hábil que ficará em poder da instituição". Com o aumento do número de ações escriturais por parte das companhias abertas, a importância dos lançamentos como base para a realização dos negócios envolvendo ações aumentou muito de importância.

${ }^{15}$ A isenção vem prevista na Lei 9.249/95, art. 10: "Os lucros ou dividendos calculados com base nos resultados apurados a partir do mês de janeiro de 1996, pagos ou creditados pelas pessoas jurídicas tributadas com base no lucro real, presumido ou arbitrado, não ficarão sujeitos à incidência do imposto de renda na fonte, nem integrarão a base de cálculo do imposto de renda do beneficiário, pessoa física ou jurídica, domiciliado no País ou no exterior. Parágrafo único. No caso de quotas ou ações distribuídas em
} 
No entanto, distribuído sem a efetivação dos devidos processos escriturais, o lucro antecipado passa a não ser mais considerado pelo ordenamento jurídico como tal, mas como remuneração outra aos sócios (p. ex.: parcelas de pró-labore, pagamento de serviços, aluguéis e congêneres), sofrendo a tributação respectiva.

Nesse sentido, temos um exemplo claro na Instrução Normativa Previdenciária MPS/SRP n. 3, de 14 de julho de 2005 (DOU de 15/07/2005), que ora transcrevemos com grifos nossos:

$\S 5^{\circ}$ No caso de Sociedade Simples de prestação de serviços relativos ao exercício de profissões legalmente regulamentadas, a contribuição da empresa em relação aos sócios contribuintes individuais terá como base de cálculo:

I - a remuneração paga ou creditada aos sócios em decorrência de seu trabalho, de acordo com a escrituração contábil da empresa, formalizada conforme disposto no inciso IV do caput e no $\$ 4^{o}$, ambos do art. 60;

II - os valores totais pagos ou creditados aos sócios, ainda que a título de antecipação de lucro da pessoa jurídica, quando não houver discriminacão entre a remuneracão decorrente do trabalho $e \quad$ a proveniente do capital social, ou tratar-se de adiantamento de resultado ainda não apurado por meio de demonstracão de resultado do exercício ou quando a contabilidade for apresentada de forma deficiente.

$\S 6^{\circ}$ Para fins do disposto no inciso II do $\S 5^{\circ}$, o valor a ser distribuído a título de antecipacão de lucro poderá ser previamente apurado mediante a elaboracão de balancetes contábeis mensais, devendo, nesta hipótese, ser observado que, se a demonstracão de resultado final do exercício 
evidenciar uma apuracão de lucro inferior ao montante distribuído, a diferenca será considerada remuneração aos sócios.

A mesma situação acontecerá com a distribuição de lucros e dividendos ao final do exercício, não demonstrada em balanço respectivo. Vejam-se, para tanto, as ementas das decisões seguintes, provenientes da esfera administrativa da Receita Federal (também com grifos nossos):

MINISTÉRIO DA FAZENDA

SECRETARIA DA RECEITA FEDERAL

DELEGACIA DA RECEITA FEDERAL DE JULGAMENTO NO RIO DE JANEIRO

$9^{a}$ TURMA

ACÓRDÃO No 5887 de 07 de outubro de 2004

ASSUNTO: Imposto sobre a Renda Retido na Fonte - IRRF

EMENTA: LUCROS E DIVIDENDOS NÃO APURADOS EM

BALANCO. Está sujeito à incidência do imposto na fonte, calculado na forma do art. 629 do RIR/1994, a distribuicão de rendimentos, a título de lucros ou dividendo, pagos por pessoa jurídica a pessoa física, que não tenham sido apurados em balanco. DIREITO DE DEFESA. CERCEAMENTO. INOCORRÊNCIA. A alegação genérica de ocorrência de cerceamento de direito de defesa deve ser rejeitada, ainda mais quando a fiscalização e a autuação foram feitas nos termos da legislação aplicável.

MINISTÉRIO DA FAZENDA

SECRETARIA DA RECEITA FEDERAL

DELEGACIA DA RECEITA FEDERAL DE JULGAMENTO EM SANTARÉM

$2^{a}$ TURMA

ACÓRDÃO No 730 de 26 de julho de 2002

ASSUNTO: Imposto sobre a Renda de Pessoa Física - IRPF 
EMENTA: TRANSFERENNCIA DE VEÍCULO. A mudança de propriedade de veículos automotores se prova pelo Certificado de Registro de Veículo, emitido pelos DETRANs. DOCUMENTO PARTICULAR. A eficácia, inclusive a probatória, de instrumento particular, antes de transcrito no Registro Público, se opera entre as partes, não em relação a terceiros. ISENÇÃO. DISTRIBUICÃO DE LUCROS. A isencão prevista no artigo 10 da Lei $n^{\circ}$ 9.249, de 1995, não abrange os valores pagos a título de prólabore, aluguéis e servicos prestados, bem como os lucros e dividendos distribuídos que não tenham sido apurados em balanco.

Ano-calendário: 1997, 1998

Considera-se, portanto, o seguinte: só haverá lucro propriamente considerado (e também lucro antecipado), com as consequiências de isenção tributária daí advindas, se apurado aquele através da devida escrituração e conseqüente evidenciação através de demonstrações contábeis respectivas.

Caso assim não ocorra, de lucro não se tratará na hipótese, considerando a distribuição aos sócios como categoria jurídica distinta, qual seja, simples remuneração destes, incidindo no caso a tributação respectiva.

Significa dizer, por outros termos, que, na ausência de escrituração, as normas jurídicas supracitadas entenderam por receber o lucro ocorrido no período, e os conseqüentes dividendos distribuídos, como pagamentos ou transferências financeiras de outra natureza efetuadas pela pessoa jurídica aos sócios.

Assim, não houve na hipótese lucro propriamente conceituado, o que só poderia ocorrer se houvesse o regular processo escritural.

Dessa forma, verifica-se que a escrituração influenciou na existência real da categoria jurídica subjacente (fazendo que o ordenamento não considerasse existente lucro, mas outra espécie tributada de remuneração), consubstanciando-se a atividade escritural 
em forma "ad substantiam" e em verdadeiro elemento completante do suporte fático do negócio jurídico em si.

Explicação interessante (levantando exemplo similar, plenamente aplicável ao caso) quanto à inexistência de determinado ato ou negócio jurídico pela falta de um elemento completante de seu suporte fático, é a referida por Marcos Bernardes de Mello: "No mútuo, por se tratar de negócio jurídico real, em que o suporte fático se compõe do acordo de vontades, mais a entrega da coisa fungível (=consensus + traditio), esta constitui elemento completante do seu núcleo. Se há o acordo sobre o mútuo, mas não se realiza a entrega da coisa emprestada, mútuo não há, existindo apenas uma promessa de mútuo que, se não cumprida, pode dar ensejo ao ressarcimento pelas perdas e danos resultantes do inadimplemento (...) Algumas vezes, embora raras, a forma do negócio jurídico entra no suporte fático como elemento completante. Se as disposições de última vontade não forem feitas através das formas de testamento previstas no Código Civil (e.g. forem gravadas em vídeo tape ou dirigidas em carta a alguém) testamento não há"16.

A escrituração, no caso em tela, constituiu-se em elemento completante do negócio jurídico mencionado (distribuição de lucros ou dividendos), consubstanciando verdadeira forma interna inerente à existência do ato em si. Sua ausência na hipótese fez com que - da mesma forma que o mútuo sem a tradição seja recebido pelo ordenamento como categoria diversa (mera promessa) - o negócio jurídico não se configurasse como tal, mas como outra forma remuneratória dos sócios.

Em conclusão, temos que, dependendo do caso concreto, a escrituração poderá ser meramente probatória (não influenciando no aperfeiçoamento, existência, validade ou eficácia do negócio escriturado) como poderá assumir o papel de formalidade essencial à substância e existência do negócio jurídico, sem a qual este não será recebido pelo ordenamento nos termos pretendidos pelas partes interessadas.

\footnotetext{
${ }^{16}$ MELLO, Marcos Bernardes de. Teoria do fato jurídico: plano da existência. São Paulo: Saraiva, 1995. p.
} 44. 


\section{A ESCRITURAÇÃO EMPRESARIAL E SEUS PROCESSOS. REQUISITOS E PRINCÍPIOS CONTÁBEIS GERAIS DA ESCRITURAÇÃO}

A escrituração empresarial não pode ser aleatória. Embora nos primórdios das atividades humanas de natureza econômica referido processo pudesse ter natureza simplificada, acessível a qualquer um que não dominasse qualquer técnica, hoje a atividade escritural exige cada vez mais a especialização de quem a pratica ou de quem a observa com as mais diversas finalidades.

Assim, há necessidade de que a escrituração se desenvolva tendo como base um processo científico que lhe dê validade e confiança, de modo que ela possa servir à sua finalidade precípua de se constituir um sistema de informações sobre a atividade econômica da empresa para fins internos e externos.

Por tal motivo, desenvolveu-se durante séculos a metodologia científica contábil que, como vimos anteriormente, teve grande incremento com a obra de Pacioli.

Obviamente, não serão tratados no presente trabalho todos os princípios e processos contábeis existentes, bastando por ora um breve panorama de sua existência.

De forma resumida, podemos dizer que a contabilidade separa os diversos aspectos da atividade empresarial em quatro grupos básicos de contas, inter-relacionados:

1) Ativo: que consubstancia os bens, créditos e demais direitos da empresa;

2) Passivo: que abrange as obrigações e dívidas da empresa; 
3) Patrimônio líquido: resultante da diferença entre ativo e passivo;

4) Resultado: compreende as contas concernentes às receitas e despesas oriundas do exercício da atividade empresarial.

As contas de cada grupo acima têm, por convenção, uma forma específica de aumento e diminuição de seu montante, que apresentamos no quadro a seguir:

Quadro 1: formas de aumento e diminuição entre as contas dos diversos grupos

\begin{tabular}{|c|c|}
\hline \multirow{2}{*}{ Ativo } & Aumenta a débito \\
\cline { 2 - 2 } Passivo & Reduz-se a crédito \\
\cline { 2 - 2 } & Aumenta a crédito \\
\hline \multirow{2}{*}{ Patrimônio Líquido } & Reduz-se a débito \\
\cline { 2 - 2 } & Aumenta a crédito \\
\hline \multirow{2}{*}{ Resultado } & Reduz-se a débito \\
\cline { 2 - 2 } & Aumenta a crédito \\
\hline
\end{tabular}

A principal técnica desenvolvida por Pacioli, chamada de método das partidas dobradas, consiste no fato de que para qualquer operação econômica deverá haver, no mínimo, um lançamento contábil a débito e um congênere a crédito, em ao menos duas contas distintas, de modo que a soma do débito seja igual à soma do crédito.

\section{Exemplifiquemos:}

Suponhamos que uma sociedade decida adquirir à vista um novo imóvel para sua sede, pagando por ele $\mathrm{R} \$ 100.000,00$ (cem mil reais). Referido valor, se bem verificarmos, saiu do ativo da sociedade (caixa ou disponibilidades) e ingressou também no ativo desta, agora como ativo imobilizado (a sociedade "trocou" dinheiro por imóvel). Assim, deverá lançar o valor mencionado a crédito de caixa ou disponibilidades (contas de ativo diminuem seu valor a crédito) e o mesmo valor a débito na conta de imóveis (que aumentará pelo lançamento a débito). 
O método das partidas dobradas trouxe inegável vantagem para as técnicas de escrituração empresarial, uma vez que permitiu ao empresário a visualização dos efeitos de cada lançamento na totalidade do patrimônio da empresa. Dessa forma, muito embora sua descoberta já tenha mais de quinhentos anos de idade, ainda não foi substituído por outra técnica mais aperfeiçoada.

O contraposto do método das partidas dobradas é o método de partidas simples, no qual é utilizada uma única conta para que se lancem débitos e créditos sem correspondência ou igualdade entre ambos. É o caso do comerciante que concentra em uma única conta os lançamentos referentes à movimentação de sua conta bancária ou as compras e pagamentos feitos por determinado cliente.

Apesar de o método de partida simples conter várias falhas por não demonstrar uma visão completa do patrimônio da empresa e de seus resultados, ele é utilizado em diversos tipos de escrituração, como é o caso do Livro Caixa, que veremos mais adiante.

Além de obedecer a certas técnicas ou métodos, a escrituração empresarial segue também diversos princípios contábeis ${ }^{17}$.

De acordo com a Resolução CFC n. 750/93, que dispõe sobre os Princípios Fundamentais de Contabilidade (PFC), são princípios fundamentais da contabilidade os transcritos no quadro seguinte.

${ }^{17}$ Há certa divergência na doutrina contábil sobre o que se deve considerar como princípio, convenção ou postulado. Não entraremos nessa divergência no texto, uma vez que entendemos não caber aqui o aprofundamento da questão. 


\section{Quadro 2: princípios gerais de contabilidade}

\begin{tabular}{|c|c|}
\hline Princípio & Descrição \\
\hline I) o da ENTIDADE; & $\begin{array}{l}\text { O Princípio da ENTIDADE reconhece o } \\
\text { Patrimônio como objeto da Contabilidade e } \\
\text { afirma a autonomia patrimonial, a } \\
\text { necessidade da diferenciação de um } \\
\text { Patrimônio particular no universo dos } \\
\text { patrimônios existentes, independentemente } \\
\text { de pertencer a uma pessoa, um conjunto de } \\
\text { pessoas, uma sociedade ou instituição de } \\
\text { qualquer natureza ou finalidade, com ou } \\
\text { sem fins lucrativos. Por conseqüência, } \\
\text { nesta acepção, o Patrimônio não se } \\
\text { confunde com aqueles dos seus sócios ou } \\
\text { proprietários, no caso de sociedade ou } \\
\text { instituição. }\end{array}$ \\
\hline II) o da CONTINUIDADE; $;^{18}$ & $\begin{array}{l}\text { A CONTINUIDADE } \text { ou não da } \\
\text { ENTIDADE, bem como sua vida definida } \\
\text { ou provável, devem ser consideradas } \\
\text { quando da classificação e avaliação das } \\
\text { mutações patrimoniais, quantitativas e } \\
\text { qualitativas. A CONTINUIDADE } \\
\text { influencia o valor econômico dos ativos e, } \\
\text { em muitos casos, o valor ou o vencimento } \\
\text { dos passivos, especialmente quando a } \\
\text { extinção da ENTIDADE tem prazo } \\
\text { determinado, previsto ou previsível. A } \\
\text { observância do Princípio da } \\
\text { CONTINUIDADE é indispensável à } \\
\text { correta aplicação do Princípio da } \\
\text { COMPETENCIA, por efeito de se } \\
\text { relacionar diretamente à quantificação dos } \\
\text { componentes patrimoniais e à formação do } \\
\text { resultado, e de constituir dado importante } \\
\text { para aferir a capacidade futura de geração } \\
\text { de resultado. }\end{array}$ \\
\hline
\end{tabular}

${ }^{18}$ O princípio da continuidade, juntamente com o princípio da prudência, é também adotado no art. 2.423 do Código Civil Italiano: "la valutazione delle voci deve essere fatta secondo prudenza e nella prospettiva della continuazione dell'attività”. 


\begin{tabular}{|c|c|}
\hline III) o da OPORTUNIDADE; & $\begin{array}{l}\text { O Princípio da OPORTUNIDADE refere- } \\
\text { se, simultaneamente, à tempestividade e à } \\
\text { integridade do registro do patrimônio e das } \\
\text { suas mutações, determinando que este seja } \\
\text { feito de imediato e com a extensão correta, } \\
\text { independentemente das causas que as } \\
\text { originaram. Como resultado da observância } \\
\text { do Princípio da OPORTUNIDADE: I - } \\
\text { desde que tecnicamente estimável, o } \\
\text { registro das variações patrimoniais deve ser } \\
\text { feito mesmo na hipótese de somente existir } \\
\text { razoável certeza de sua ocorrência; II - o } \\
\text { registro compreende os elementos } \\
\text { quantitativos e qualitativos, contemplando } \\
\text { os aspectos físicos e monetários; III - o } \\
\text { registro deve ensejar o reconhecimento } \\
\text { universal das variações ocorridas no } \\
\text { patrimônio da ENTIDADE, em um período } \\
\text { de tempo determinado, base necessária para } \\
\text { gerar informações úteis ao processo } \\
\text { decisório da gestão. }\end{array}$ \\
\hline $\begin{array}{l}\text { IV) o do REGISTRO PELO VALOR } \\
\text { ORIGINAL; }\end{array}$ & $\begin{array}{l}\text { Os componentes do patrimônio devem ser } \\
\text { registrados pelos valores originais das } \\
\text { transações com o mundo exterior, } \\
\text { expressos a valor presente na moeda do } \\
\text { País, que serão mantidos na avaliação das } \\
\text { variações patrimoniais posteriores, } \\
\text { inclusive quando configurarem agregações } \\
\text { ou decomposições no interior da } \\
\text { ENTIDADE. Do Princípio do REGISTRO } \\
\text { PELO VALOR ORIGINAL resulta: I - a } \\
\text { avaliação dos componentes patrimoniais } \\
\text { deve ser feita com base nos valores de } \\
\text { entrada, considerando-se como tais os } \\
\text { resultantes do consenso com os agentes } \\
\text { externos ou da imposição destes; II - uma } \\
\text { vez integrado no patrimônio, o bem, direito } \\
\text { ou obrigação não poderão ter alterados seus } \\
\text { valores intrínsecos, admitindo-se, tão- } \\
\text { somente, sua decomposição em elementos } \\
\text { e/ou sua agregação, parcial ou integral, a } \\
\text { outros elementos patrimoniais; III - o valor } \\
\text { original será mantido enquanto o } \\
\text { componente permanecer como parte do } \\
\text { patrimônio, inclusive quando da saída } \\
\text { deste; IV - os Princípios da } \\
\text { ATUALIZAÇÃO MONETÁRIA e do } \\
\text { REGISTRO PELO VALOR ORIGINAL } \\
\text { são compatíveis entre si e complementares, } \\
\text { dado que o primeiro apenas atualiza e } \\
\text { mantém atualizado o valor de entrada; V - } \\
\text { o uso da moeda do País na tradução do } \\
\text { valor dos componentes patrimoniais } \\
\text { constitui imperativo de homogeneização } \\
\text { quantitativa dos mesmos. }\end{array}$ \\
\hline
\end{tabular}


V) o da ATUALIZAÇÃO MONETÁRIA;

Os efeitos da alteração do poder aquisitivo da moeda nacional devem ser reconhecidos nos registros contábeis através do ajustamento da expressão formal dos valores dos componentes patrimoniais. São resultantes da adoção do Princípio da ATUALIZAÇÃO MONETÁRIA: I - a moeda, embora aceita universalmente como medida de valor, não representa unidade constante em termos do poder aquisitivo; II - para que a avaliação do patrimônio possa manter os valores das transações originais (art. $7^{\circ}$ ), é necessário atualizar sua expressão formal em moeda nacional, a fim de que permaneçam substantivamente corretos os valores dos componentes patrimoniais e, por conseqüência, o do patrimônio líquido; III - a atualização monetária não representa nova avaliação, mas, tão-somente, o ajustamento dos valores originais para determinada data, mediante a aplicação de indexadores, ou outros elementos aptos a traduzir a variação do poder aquisitivo da moeda nacional em um dado período. 


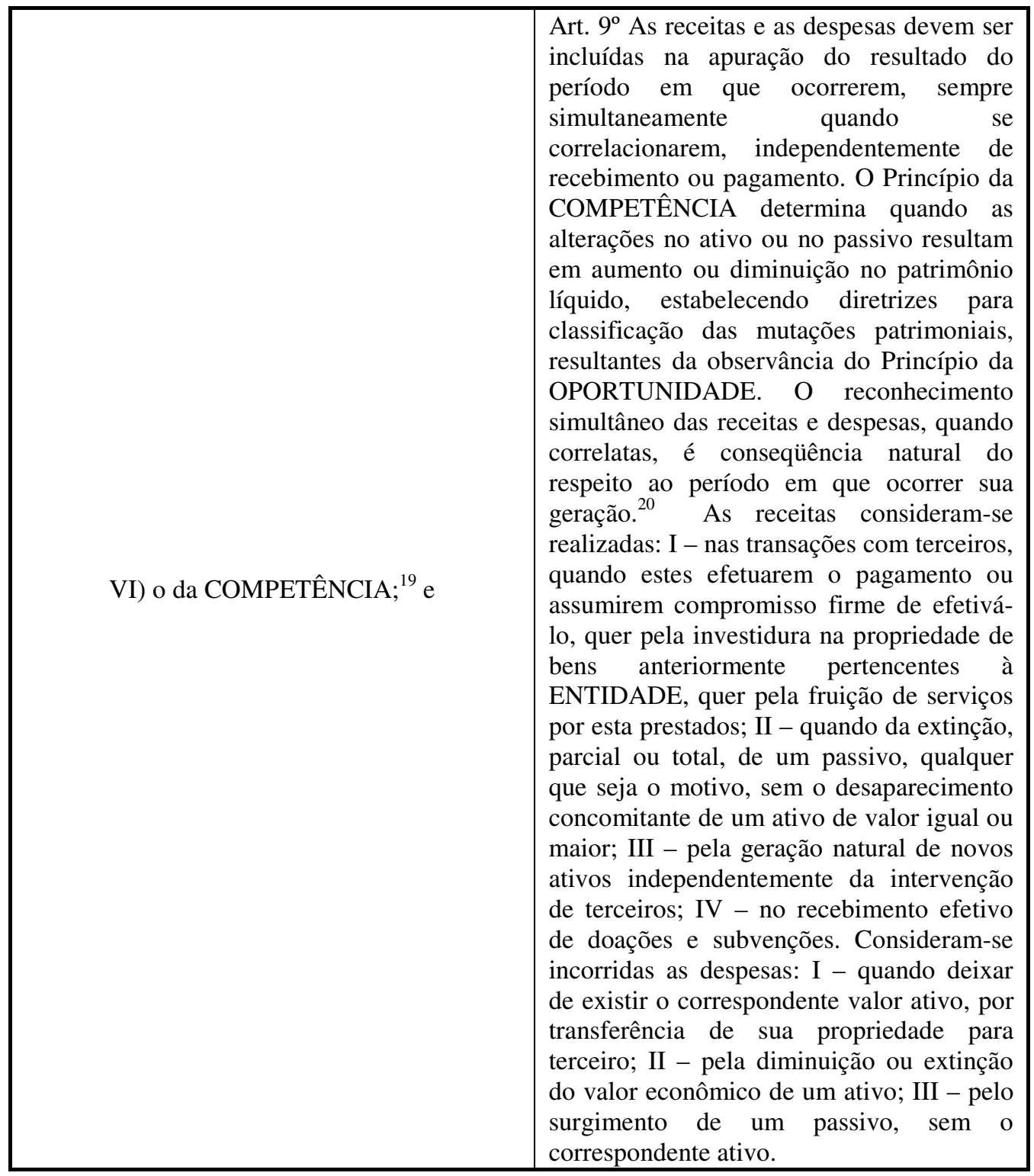

${ }^{19}$ Também o art. 2.423 do Código Civil italiano adota o princípio da competência: "si deve tener conto dei proventi e degli oneri di competenza dell'esercizio, indipendentemente dalla data dell'incasso o del pagamento".

${ }^{20}$ Há casos especiais referidos nas normas internacionais de contabilidade (IFRS) que não correspondem estritamente ao princípio da correlação entre receitas e despesas. Exemplo disso são os contratos de construção de longo prazo em que usualmente a receita é reconhecida em termos percentuais à conclusão de obra ou aos custos incorridos. 
VII) o da PRUDÊNCIA.

O Princípio da PRUDÊNCIA determina a
adoção do menor valor para os
componentes do ATIVO e do maior para os
do PASSIVO, sempre que se apresentem
alternativas igualmente válidas para a
quantificação das mutações patrimoniais
que alterem o patrimônio líquido. O
Princípio da PRUDÊNCIA impõe a escolha
da hipótese de que resulte menor
patrimônio líquido, quando se
apresentarem opções igualmente aceitáveis
diante dos demais Princípios Fundamentais
de Contabilidade. Observado o disposto no
art. 7o, o Princípio da PRUDÊNCIA
somente se aplica às mutações posteriores,
constituindo-se ordenamento indispensável
à correta aplicação do Princípio da
COMPETÊNCIA. A aplicação do Princípio
da PRUDÊNCIA ganha ênfase quando,
para definição dos valores relativos às
variações patrimoniais, devem ser feitas
estimativas que envolvem incertezas de
grau variável.

Obviamente que a aplicação dos princípios contábeis, apesar de serem de observância obrigatória pelo contabilista, deve ser analisada conforme o caso. Segundo a Resolução 750/93, na aplicação dos Princípios Fundamentais de Contabilidade há situações concretas e a essência das transações deve prevalecer sobre seus aspectos formais.

\subsection{Escrituração empresarial e fiscal}

\subsubsection{Conceituação, semelhanças e distinções}

Historicamente a doutrina apresenta a distinção entre os livros comerciais (empresariais) e fiscais.

Tal separação tem se apresentado em virtude de que as categorias ora mencionadas possuiriam, ao ver de muitos doutrinadores, fundamentos legais, finalidades e métodos de escrituração diversos. 
Leciona Rubens Requião, quanto aos livros fiscais, que: “Tendo em vista certos princípios de fiscalização, as leis tributárias da União, dos Estados e dos Municípios instituem os chamados livros fiscais. Embora, em princípio, não pertençam ao âmbito do direito comercial, as leis tributárias geralmente os exigem ao lado dos livros obrigatórios ${ }^{21}$.

Do mesmo modo o Prof. Waldirio Bulgarelli, para quem "Ao lado dos livros obrigatórios decorrentes das leis comerciais estão os impostos pelas leis fiscais. São instituídos no interesse do controle e da cobrança de tributos. (...) Pelas constantes alterações a que estão sujeitos, na dependência da política fiscal e por se tratar de livros que interessam mais de perto às questões tributárias, seu estudo deve ser feito no âmbito do Direito Tributário",22.

Há de se notar que, embora ainda apresente relevo, a distinção conceitual feita pelos esmerados doutrinadores citados não se põe mais como uma separação absoluta.

Primeiramente, em virtude de tais livros tratarem essencialmente do mesmo objeto, qual seja, a atividade econômica do empresário. Seguem, além disso, uma mesma linha de essência e metodologia: os princípios da ciência contábil. E por tratarem de um mesmo fenômeno da mesma maneira já é possível perceber que a separação proposta pela doutrina não traz distinções ontológicas entre as categorias.

Pode-se realmente verificar a diminuição da importância da distinção entre livros comerciais e fiscais, quando se verifica que a legislação fiscal (máxime a que regula o imposto sobre a renda) exige dos empresários a escrituração de livros considerados historicamente pela doutrina como comerciais.

Vejam-se, por exemplo, os livros Caixa e Registro de Inventário (exigidos pela legislação fiscal das empresas tributadas com base no lucro presumido e das micro e pequenas empresas) ${ }^{23}$, que foram referenciados sempre pela doutrina comercialista como

\footnotetext{
${ }^{21}$ REQUIÃO, Rubens. Op. cit., v.1, p. 134.

22 BULGARELLI, Waldirio. Direito Comercial. São Paulo: Atlas, 1991. p. 136.

${ }^{23}$ Diz a Lei n. 8.981, de 20 de janeiro de 1995, que: "Art. 45. A pessoa jurídica habilitada à opção pelo regime de tributação com base no lucro presumido deverá manter: I - escrituração contábil nos termos da legislação comercial; II - Livro Registro de Inventário, no qual deverão constar registrados os estoques
} 
livros comerciais facultativos ou auxiliares. Na lição sempre abalizada do Prof. Waldirio Bulgarelli ${ }^{23 \mathrm{~A}}$, citando Waldemar Ferreira: "São inúmeros os livros auxiliares. Variam de nome, feitio, quantidade e, até, de tamanho e formato. O borrador, também chamado memorial ou costaneira, destina-se a receber o primeiro lançamento das operações mercantis. Divide-se em borrador sujo e borrador limpo. Podem existir vários desses livros, em cada seção, armazém, loja ou depósito do mesmo estabelecimento. Todos escrevem na costaneira, a lápis ou a tinta. Os seus lançamentos transferem-se para o borrador limpo. Transplantam-se, em seguida, para os outros vários livros. Neles se prolongam e desdobram. Para o contas-corrente, trasladam-se os lançamentos em contas pessoais, em regra a cada freguês uma página no seu débito ou no seu crédito, se ativa ou passiva a operação realizada. Dessarte, nele se desdobra a situação exata de cada freguês. Sabe-se a todo instante se ele é devedor ou credor. Ministra o livro, portanto, o índice seguro da vida de cada qual. Disso lhe resulta a importância. Para o razão as contas transferem-se objetivamente. Existe, em cada página, conta relativa a cada título do diário, que dele, mais de perto, se alimenta. Por ele sabe o comerciante da situação de todas as contas gerais. Mercadorias. Despesas gerais. Juros e descontos. Por. isso, é o livro obrigatório, em alguns países. Conjuga-se, com aqueles, o livro caixa, em alguns estabelecimentos revestido das formalidades peculiares aos livros obrigatórios, quanto a rubrica e selo. A contabilidade, dessarte, seguramente se entrosa em sistema consentâneo com as necessidades comuns do comércio. Livro de mercadorias ou fazendas gerais. Livro de letras e obrigações a pagar. Livro de letras e obrigações a receber. Livro de inventários. Livro de balanços. Eis outros, encontradiços na generalidade dos escritórios comerciais, cooperando para o bom sucesso do empreendimento”.

Diante disso, entendemos importante citar aqui a conclusão a que chega Fábio Ulhoa Coelho: “A disciplina da escrituração de um livro contábil pode se encontrar na legislação comercial ou tributária. Em função disso, a doutrina costuma classificar os livros em mercantis e fiscais. Não existe, contudo, nenhuma diferença entre os livros de uma ou outra dessas categorias, no tocante aos requisitos de escrituração, às hipóteses de

existentes no término do ano-calendário abrangido pelo regime de tributação simplificada; III - em boa guarda e ordem, enquanto não decorrido o prazo decadencial e não prescritas eventuais ações que lhes sejam pertinentes, todos os livros de escrituração obrigatórios por legislação fiscal específica, bem como os documentos e demais papéis que serviram de base para escrituração comercial e fiscal. Parágrafo único. $O$ disposto no inciso I deste artigo não se aplica à pessoa jurídica que, no decorrer do ano-calendário, mantiver livro Caixa, no qual deverá estar escriturado toda a movimentação financeira, inclusive bancária”. 23A BULGARELLI, Waldirio. Op cit., p. 138. 
exibição judicial, ou perante autoridade administrativa, e às responsabilidades do empresário pela sua falta ou irregularidade. A classificação, assim, não se justifica senão para fins didáticos: ao direito comercial, enquanto disciplina curricular, cabe enumerar os livros mercantis; ao direito tributário, os fiscais. Reafirme-se, contudo, que é idêntico o regime jurídico atinente aos livros contábeis exigidos pela lei comercial e pela lei tributária",24.

Não há, portanto, diferença substancial entre escrituração comercial e fiscal, restando distinções de origem (fonte), conteúdo e método. Ambas cuidam, na verdade, de matéria única cujo âmbito engloba a consignação, em forma contábil, de fatos econômicos relevantes no exercício empresarial.

Mas muito embora não existam distinções de essência ou ontológicas entre a escrituração mercantil e escrituração fiscal, a dicotomia entre escrituração fiscal e comercial ainda não pode ser considerada superada.

Com efeito, é comum termos para cada tipo tributário um conjunto de obrigações acessórias vinculadas a uma espécie própria de escrituração fiscal, que enfatiza certos registros e lançamentos, com metodologia própria; obrigações essas que não são obrigatórias pela legislação comercial ${ }^{25}$.

Outras vezes, conquanto tratem da mesma matéria, os métodos e critérios utilizados pela escrituração comercial e fiscal são essencialmente distintos, pois a legislação tributária impõe algumas nuances específicas nos livros que exige, visando a situações peculiares.

Essas divergências entre os critérios de escrituração do fisco e aqueles determinados pela contabilidade em geral são fatos que em muito derivam da filosofia meramente arrecadatória que permeia o conjunto de normas tributárias nacionais que, para

\footnotetext{
${ }^{24}$ COELHO, Fábio Ulhoa. Curso de Direito Comercial. São Paulo: Saraiva, 2003. v. 1, p. 98.

${ }^{25}$ Veja-se como exemplo a escrituração dos livros de apuração do lucro real (LALUR) e Razão para as sociedades tributadas no sistema de lucro real. Considerem-se ainda os diversos livros exigidos para a escrituração de operações envolvendo tributos estaduais e municipais, como os livros de registro de entradas e saídas de mercadorias (ICMS), etc.
} 
aumentar a carga tributária sobre o contribuinte, rejeitam a adoção de vários princípios contábeis universalmente aceitos.

E há bons exemplos disso, dos quais aqui mencionaremos apenas alguns, de maneira breve.

Podemos citar os referidos por Iudícibus et al., que ensinam: "O enfoque essencialmente fiscal que as autoridades governamentais têm inserido em seus estudos não só ignora essa tendência mundial como também representa um retrocesso em relação a algumas evoluções já conquistadas. Situam-se nesse campo, por exemplo, a proibição, inclusive para fins societários, do reconhecimento dos efeitos da inflação nas demonstrações contábeis e de redução ou até mesmo de eliminação de provisões tecnicamente corretas e necessárias. Essa é uma atitude que, para nós, parece muito pouco madura e incompatível com o objetivo de modernização do Brasil, como todos procuramos" ${ }^{26}$.

Até mesmo em circunstâncias nas quais não se vislumbra o propósito meramente arrecadatório, as divergências existem. Os juros sobre capital próprio, por exemplo, são tratados diferentemente pela legislação tributária e pelas normas da Comissão de Valores Mobiliários.

Sua criação, através da Lei n. 9.249/95, conceituou os juros sobre capital próprio como despesa, a serem incluídos no resultado da empresa, como se verifica do art. $9^{\circ}$ da Lei, ora transcrito:

Art. $9^{\circ}$ A pessoa jurídica poderá deduzir, para efeitos da apuração do lucro real, os juros pagos ou creditados individualizadamente a titular, sócios ou acionistas, a título de remuneração do capital próprio, calculados sobre as contas do patrimônio líquido e limitados à variação, pro rata dia, da Taxa de Juros de Longo Prazo - TJLP.

\footnotetext{
${ }^{26}$ IUDÍCIBUS, Sérgio de; MARTINS, Eliseu; GELBCKE, Ernesto Rubens. Manual de contabilidade das sociedades por ações. São Paulo: Atlas, 2003. p. 29.
} 
Já a CVM, em sua resolução 207/96, determinou que tais verbas são, em realidade, equiparadas aos dividendos recebidos pelos acionistas, saindo diretamente da conta lucros acumulados e não afetando o resultado do exercício, nos seguintes termos:

I - Os juros pagos ou creditados pelas companhias abertas, a título de remuneração do capital próprio, na forma do artigo $9^{\circ}$ da Lei $n$. 9.249/95, devem ser contabilizados diretamente à conta de Lucros Acumulados, sem afetar o resultado do exercício.

Para tais casos, restará à sociedade anônima a aplicação do art. 177, § $2^{\circ}$, da Lei n. 6.404/1976 (com redação da Lei n. 11.638/07), que determina que as disposições da lei tributária ou de legislação especial sobre atividade que constitui o objeto da companhia que conduzam à utilização de métodos ou critérios contábeis diferentes ou à elaboração de outras demonstrações não elidem a obrigação de elaborar, para todos os fins desta Lei, demonstrações financeiras em consonância com o disposto no caput do artigo 177 e deverão ser alternativamente observadas mediante registro: I - em livros auxiliares, sem modificação da escrituração mercantil; ou II - no caso da elaboração das demonstrações para fins tributários, na escrituração mercantil, desde que sejam efetuados em seguida lançamentos contábeis adicionais que assegurem a preparação e a divulgação de demonstrações financeiras com observância do disposto no caput deste artigo, devendo ser essas demonstrações auditadas por auditor independente registrado na Comissão de Valores Mobiliários.

Nesse caso, para segurança da sociedade em face do fisco, uma vez que esta se encontra na posição de contribuinte que tem de escriturar obedecendo a mais de uma norma (uma societária e outra tributária) para uma mesma realidade econômica, a Lei n. 11.638/07 adicionou o $\S 7^{\circ}$ do art. 177 da Lei n. 6.404/76, aduzindo que os lançamentos de ajuste efetuados exclusivamente para harmonização de normas contábeis, nos termos do $\S$ $2^{\circ}$ do mesmo artigo, e as demonstrações e apurações com eles elaboradas não poderão ser base de incidência de impostos e contribuições nem ter quaisquer outros efeitos tributários $^{27}$.

${ }^{27}$ Sobre o emprego desse artigo na divergência de critérios entre a legislação comercial e tributária, é interessante o decidido pelo Superior Tribunal de Justiça no REsp 413919/PR; RECURSO ESPECIAL 2002/0018804-7, Relator(a) Ministro JOSÉ DELGADO (1105) Órgão Julgador T1 - PRIMEIRA TURMA, 
Em conclusão, temos que ainda não se pode dizer superada a dicotomia entre escrituração empresarial e fiscal, muito embora não haja distinção em sua essência, mas se separam de forma nítida quando visualizamos sua fonte, origem, conteúdo e metodologia.

\subsubsection{Dispensa de escrituração empresarial pela legislação}

fiscal

Há ainda mais um fato relevante a ser analisado dentro do cotejo entre a escrituração comercial e a fiscal. Isso porque, muitas vezes, a legislação tributária, principalmente a que regula o imposto sobre a renda e proventos de qualquer natureza, influencia fortemente as obrigações escriturais, determinando quais livros serão efetivamente obrigatórios e dispensando os empresários de certos tipos de escrituração.

data do julgamento 17/09/2002, data da publicação/fonte DJ 07.10.2002 p. 194. RDDT vol. 87 p. 228: “TRIBUTÁRIO. IRPJ E CSSL. INSTITUIÇÃO FINANCEIRA. LUCRO REAL.DEDUÇÃO. PROVISÃO PARA CRÉDITOS DE LIQUIDAÇÃO DUVIDOSA (OU PDD-PROVISÃO PARA DEVEDORES DUVIDOSOS). LEIS 8.981/95 E 4.595/64. RESOLUÇÃO 1.748/90 DO BACEN. IN/SRF 51/95. ARTS. 43 E 44, DO CTN. ANTINOMIA. NÃO CONFIGURAÇÃOO. 1. Na presença de conflito aparente de normas, considera-se, sempre, o sistema jurídico a que as mesmas pertencem, sem vez para análise isolada de uma delas (RMS 6905/SP, Rel. Min. Edson Vidigal, DJU 14/06/99). 2. A IN/SRF n. $51 / 95$ não colide com a Resolução $n$. 1748/90, do BACEN, posto que tratam de objetos diversos, ou seja, enquanto ao BACEN cabe regular e fiscalizar as atividades das instituições financeiras, sendo a aludida Resolução norma definidora do dever contábil e de segurança previsto para a atividade financeira, à Receita Federal cabe a incumbência de exigir e fiscalizar a arrecadação de tributos, sendo a referida Instrução norma definidora de dever fiscal aplicável às instituições financeiras. 3. A Lei $n$. 8.981/95 não se confronta com a Lei n. 4.595/64 na medida em que, enquanto a primeira determina alterações na legislação tributária federal, a segunda limita-se a organizar, de modo genérico, a Política e as Instituições Monetárias, Bancárias e Creditícias, tendo criado, inclusive, o Conselho Monetário Nacional. 4. Não ofende o sistema jurídico vigente o fato de as normas (comercias e fiscais) divergirem quanto à fixação do montante a ser lançado na respectiva provisão de créditos de liquidação duvidosa. A fórmula de composição da PDD - Provisão para Devedores Duvidosos, para fins fiscais, deve obediência ao estatuído na legislação fiscal pertinente, no caso, a Lei n. 8.981/95, não havendo que se cogitar em violação ao teor prescrito pelos arts. 43 e 44, do CTN. 5. A legislação tributária, peculiarmente a do imposto de renda, reclama o emprego de técnicas não inteiramente conciliáveis com as de legislação comercial. A Lei n. 6.404, de 15 de dezembro de 1976 (reguladora das Sociedades por Ações), prevê a possibilidade de que a empresa faça sua escrituração em registros auxiliares quando as normas tributárias exijam métodos ou critérios contábeis diferenciados ou determinem simplesmente a elaboração de outras demonstrações financeiras. 6. Recurso especial parcialmente conhecido e, nesta parte, improvido". 
Tem havido nesta matéria uma intensa divergência na jurisprudência, além de uma grande disputa entre juristas e contabilistas, ora se afirmando a possibilidade de dispensa de escrituração comercial pela legislação tributária, ora a inviabilidade de referida desobrigação.

Analisaremos aqui dois dos exemplos mais nítidos, quais sejam, as Leis $\mathrm{n}$. $8.981 / 95$ e $9.317 / 96^{28}$, que vieram a dispensar a escrituração completa para empresas tributadas em relação ao imposto sobre a renda com base no sistema lucro presumido ou no regime simplificado (SIMPLES), desde que mantida a escrituração exigida em substituição (normalmente os livros Caixa e Registro de Inventário).

Lei n. 8.981/95 (grifos nossos):

Art. 45. A pessoa jurídica habilitada à opção pelo regime de tributação com base no lucro presumido deverá manter:

I - escrituração contábil nos termos da legislação comercial;

II - Livro Registro de Inventário, no qual deverão constar registrados os estoques existentes no término do ano-calendário abrangido pelo regime de tributação simplificada;

III - em boa guarda e ordem, enquanto não decorrido o prazo decadencial e não prescritas eventuais ações que lhes sejam pertinentes, todos os livros de escrituração obrigatórios por legislação fiscal específica, bem como os documentos e demais papéis que serviram de base para escrituração comercial e fiscal.

\footnotetext{
${ }^{28}$ Nos termos do art. 89 da Lei Complementar n. 123, de 14 de dezembro de 2006, foi revogada, a partir de $1^{\circ}$ de julho de 2007, a Lei n. 9.317, de 5 de dezembro de 1996, o mesmo ocorrendo com a Lei n. 9.841, de 5 de outubro de 1999. A nova legislação das microempresas e empresas de pequeno porte somente regulou a escrituração fiscal de tais categorias (arts. 25 e 26), não efetuando dispensa de escrituração comercial. Decidimos manter no texto o teor da legislação revogada, até pelo seu interesse histórico. Veja-se também que, mesmo com a revogação, o problema ainda se põe, pois a legislação que regula as empresas tributadas no sistema de lucro presumido ainda traz a dispensa referida.
} 
Parágrafo único. O disposto no inciso I deste artigo não se aplica à pessoa jurídica que, no decorrer do ano-calendário, mantiver livro Caixa, no qual deverá estar escriturada toda a movimentacão financeira, inclusive bancária.

Lei n. 9.317/96 (grifos nossos):

Art. $7^{o}$ A microempresa e a empresa de pequeno porte, inscritas no SIMPLES apresentarão, anualmente, declaração simplificada que será entregue até o último dia útil do mês de maio do ano-calendário subseqüente ao da ocorrência dos fatos geradores dos impostos $e$ contribuições de que tratam os arts. $3^{\circ}$ e $4^{o}$.

$\S 1^{o}$ A microempresa e a empresa de pequeno porte ficam $\underline{\text { dispensadas de }}$ escrituracão comercial desde que mantenham, em boa ordem e guarda $e$ enquanto não decorrido o prazo decadencial e não prescritas eventuais açẽes que lhes sejam pertinentes:

a) Livro Caixa, no qual deverá estar escriturada toda a sua movimentação financeira, inclusive bancária;

b) Livro de Registro de Inventário, no qual deverão constar registrados os estoques existentes no término de cada ano-calendário;

c) todos os documentos e demais papéis que serviram de base para a escrituração dos livros referidos nas alíneas anteriores.

$\S 2^{\circ} \mathrm{O}$ disposto neste artigo não dispensa o cumprimento, por parte da microempresa e empresa de pequeno porte, das obrigações acessórias previstas na legislação previdenciária e trabalhista.

A questão é saber se a dispensa referida pela legislação tributária supracitada afasta a aplicação da legislação comercial que venha a exigir a escrituração 
daqueles tributados na maneira referida, ou se a dispensa aqui tratada teria efeitos meramente no campo tributário, não influenciando a aplicabilidade da legislação comercial.

Uma primeira interpretação poderia salientar que o Código Civil se constituiria norma geral que regula a escrituração de todos os empresários, enquanto a legislação tributária faria o papel de norma especial (lex specialis). Havendo contradição (antinomia) entre seus termos, caberia invocar o ensinamento de Norberto Bobbio, segundo o qual um dos critérios a serem empregados em tais casos é o da especialidade: "O terceiro critério, dito justamente da lex specialis é aquele pelo qual, de duas normas incompatíveis, uma geral e uma especial (ou excepcional), prevalece a segunda: lex specialis derogat generali. Também aqui a razão do critério não é obscura: lei especial é aquela que anula uma lei mais geral, ou que subtrai de uma norma uma parte da sua matéria para submetê-la a uma regulamentação diferente (contrária ou contraditória) (...) Por efeito da lei especial, a lei geral cai parcialmente $" 29$.

Concluir-se-ia, portanto, que a legislação tributária (norma especial) afastaria a aplicação do Código Civil (norma geral).

Tal raciocínio, embora aparentemente correto, não chega a abranger a totalidade do tema. Se anuíssemos com a dispensa da escrituração empresarial nos termos da legislação fiscal, teríamos um grande número de hipóteses em que se apresentariam algumas dificuldades, como as seguintes:

1. A sociedade tributada com base no lucro presumido ou no sistema SIMPLES estaria sujeita ao crime falimentar referente à omissão de escrituração (art. 178 da Lei 11.101/05) $)^{30}$, diante da dispensa da escrituração comercial completa, bastando-lhe possuir e apresentar em juízo os livros Caixa elou Registro de Inventário?

\footnotetext{
${ }^{29}$ BOBBIO, Norberto. Teoria do Ordenamento Jurídico, Brasília: Polis, 1989. p. 95-6.

${ }^{30}$ Omissão dos documentos contábeis obrigatórios. Art. 178. Deixar de elaborar, escriturar ou autenticar, antes ou depois da sentença que decretar a falência, conceder a recuperação judicial ou homologar o plano de recuperação extrajudicial, os documentos de escrituração contábil obrigatórios: Pena - detenção, de 1 (um) a 2 (dois) anos, e multa, se o fato não constitui crime mais grave.
} 
2. A sociedade tributada com base no lucro presumido ou no sistema SIMPLES poderia obter concordata, recuperação judicial ou extrajudicial apresentando em juízo somente os livros Caixa elou Registro de Inventário?

3. Em uma ação de prestação de contas movida por um sócio ou terceiro, bastaria a apresentação dos lançamentos constantes dos livros Caixa elou Registro de Inventário, dispensada a escrituração completa (livro Diário)? Caso fosse solicitada a exibição judicial dos livros, acarretaria presunção de veracidade a ausência de exibição de escrituração comercial completa diante da dispensa da legislação tributária?

4. Considerando que o balanço, a demonstração de resultados do exercício e as demais demonstrações contábeis são relatórios oriundos dos lançamentos contábeis existentes em um processo escritural completo, estariam as sociedades tributadas com base no lucro real ou no sistema SIMPLES dispensadas de referidas demonstrações? Considerando ainda que o balanço e a demonstração de resultados devem ser inseridos no livro Diário, a dispensa deste pela legislação tributária também acarretaria a dispensa dos demonstrativos referidos?

Para analisar com maior vagar cada uma das questões postas acima, precisaremos antes fazer uma pequena distinção.

Como veremos com mais vagar a seguir, as sociedades empresárias que se enquadrarem na definição de microempresa ou empresa de pequeno porte gozam de dispensa de escrituração completa (livro Diário), por efeito da própria legislação comercial (arts. 970 e 1179, § 2º , do Código Civil), seja ou não optante pelo sistema SIMPLES de tributação. Caso opte pelo SIMPLES, terá de escriturar os livros Caixa e Registro de 
Inventário $^{31}$. Não optando, cairá em outro sistema de tributação (lucro presumido ou real), com novas exigências escriturais. Para todos os efeitos, porém, só é exigida da microempresa ou empresa de pequeno porte a escrituração fiscal (Lei Complementar $n$. 123/06), estando dispensada da escrituração comercial por força do disposto no Código Civil.

Ressalte-se que as microempresas e empresas de pequeno porte tiveram tratamento divergente na legislação de regência no que tange à escrituração, em passado recente. A Lei n. 7.256/84, em seu artigo 15, desobrigava a microempresa de escrituração. A isenção acima mencionada durou até a sobrevinda da Lei n. 8.864/94, que não previu dispensa de escrituração, ressaltando apenas que esta seria simplificada (art. 11). Confirmando a necessidade de escrituração do micro e pequeno empresário, a Lei n. 9.841/99, revogando a Lei n. 8.864/94, não dispôs sobre qualquer dispensa de escrituração.

O Código Civil (Lei n. 10.406/2002) dispensou o pequeno empresário da escrituração do Diário e a Lei Complementar n. 123/06 somente exigiu das microempresas e empresas de pequeno porte a manutenção de documentos relacionados à receita de vendas ou prestação de serviços e daqueles que fundamentaram exações tributárias (se optantes do SIMPLES) ou a manutenção de livro Caixa (se não optantes).

Podemos resumir o assunto no seguinte quadro:

\section{Quadro 3: escrituração exigida das microempresas e empresas de pequeno porte pelas diversas legislações que se sucederam}

\begin{tabular}{|c|c|}
\hline $\begin{array}{c}\text { Legislação (estatutos das } \\
\text { microempresas e } \\
\text { empresas de pequeno } \\
\text { porte) }\end{array}$ & Escrituração exigida \\
\hline Lei n. $7.256 / 84$ & Dispensada a escrituração (art. 15). \\
\hline Lei n. $8.864 / 94$ & $\begin{array}{c}\text { Escrituração simplificada (art. 11) não definida } \\
\text { em seus termos pelo Regulamento da Lei. }\end{array}$ \\
\hline Lei n. $9.841 / 99$ & $\begin{array}{c}\text { Escrituração completa, uma vez que, } \\
\text { revogando a legislação anterior, não instituiu } \\
\text { qualquer dispensa. }\end{array}$ \\
\hline
\end{tabular}

${ }^{31}$ O livro Registro de Inventário não teve sua exigência confirmada pela Lei Complementar n. 123/06, razão pela qual entendemos que sua exigibilidade somente há de permanecer até $1^{\circ}$ de julho de 2007 , quando foram revogadas as Leis n. 9.317, de 5 de dezembro de 1996, e n. 9.841, de 5 de outubro de 1999. 


\begin{tabular}{|c|c|}
\hline $\begin{array}{c}\text { Código Civil } \\
\text { (Lei n. 10.406/02) }\end{array}$ & $\begin{array}{c}\text { Dispensada a escrituração completa (livro } \\
\text { Diário) por efeito do art. } 1.179, \S 2^{\circ} .\end{array}$ \\
\hline & Não faz menção à escrituração \\
& empresarial/comercial, mas somente à \\
Lei Complementar n. & $\begin{array}{c}\text { escrituração como obrigação fiscal acessória. } \\
123 / 06\end{array}$ \\
& Exige a manutenção de documentos \\
& relacionados a vendas e impostos para os \\
& optantes pelo SIMPLES, ou de livro Caixa \\
& para os não optantes. \\
\hline
\end{tabular}

Dessa forma, devemos entender com certas ponderações as divergências da jurisprudência no que tange à obrigatoriedade ou não das microempresas e empresas de pequeno porte em escriturar suas obrigações, dada a dispensa efetivada pela atual legislação comercial encabeçada pelo Código Civil.

O mesmo não ocorre com as sociedades tributadas pelo lucro presumido que não se enquadrem no conceito de microempresa ou empresa de pequeno porte, as quais não ostentam qualquer dispensa de escrituração pela legislação comercial, havendo apenas a dispensa constante da legislação tributária.

Feita a distinção acima mencionada, passemos à análise das questões postas.

\subsubsection{Dispensa de escrituração e crime falimentar}

Como já salientamos, as microempresas e empresas de pequeno porte tiveram uma regulamentação diferenciada no tempo em relação à obrigatoriedade de escrituração.

Podemos verificar, entretanto, que a Lei n. 9.317/96, aqui considerada como legislação tributária, que efetivou uma dispensa de escrituração comercial completa para as microempresas e empresas de pequeno porte optantes pelo sistema SIMPLES, entrou em 
vigor no interregno entre as Leis n. 8.864/94 e n. 9.841/99, leis de natureza comercial que não efetivaram qualquer dispensa específica em relação à escrituração comercial, tendo a desobrigação sido reintroduzida com o advento do Código Civil.

Tal panorama não se alterou pelo advento da Lei Complementar n. 123/06, que não faz menção à dispensa de escrituração mercantil, tratando apenas de tal fenômeno sob o ponto de vista fiscal, ou seja, como obrigação tributária acessória.

Em relação às empresas tributadas com base no sistema de lucro presumido, nenhuma dispensa de escrituração foi inserida na legislação comercial de regência (Código Civil), de modo que a ausência de obrigatoriedade de escrituração restou apenas constante da legislação tributária.

Os crimes falimentares que dizem respeito à escrituração, nos termos da legislação de regência em cada época, contêm a seguinte redação:

Decreto-Lei n. 7.661, de 21 de junho de 1945:

Art. 186. Será punido o devedor com detenção, de 6 (seis) meses a 3 (três) anos, quando concorrer com a falência algum dos seguintes fatos:

VI - inexistência dos livros obrigatórios ou sua escrituração atrasada, lacunosa, defeituosa ou confusa;

VII - falta de apresentação do balanço, dentro de 60 (sessenta) dias após a data fixada para o seu encerramento, a rubrica do juiz sob cuja jurisdição estiver o seu estabelecimento principal.

Parágrafo único. Fica isento da pena, nos casos dos ns. VI e VII deste artigo, o devedor que, a critério do juiz da falência, tiver instrução insuficiente e explorar comércio exíguo. 
Lei n. 11.101, de 9 de fevereiro de 2005:

\title{
Omissão dos documentos contábeis obrigatórios.
}

\begin{abstract}
Art. 178. Deixar de elaborar, escriturar ou autenticar, antes ou depois da sentença que decretar a falência, conceder a recuperação judicial ou homologar o plano de recuperação extrajudicial, os documentos de escrituração contábil obrigatórios:
\end{abstract}

Pena - detenção, de 1 (um) a 2 (dois) anos, e multa, se o fato não constitui crime mais grave.

A legislação falimentar acima transcrita (Decreto-Lei n. 7.661/45 e Lei n. 11.101/05) se refere a livros e documentos contábeis obrigatórios, sem distinguir a escrituração comercial da fiscal, abrangendo ambos os tipos ${ }^{32}$.

\footnotetext{
${ }^{32}$ Essa mesma interpretação abrangente do inciso VI do art. 186 do Dec.-Lei n. 7.661/45 constou do acórdão proferido pelo Tribunal de Justiça do Distrito Federal na apelação criminal 20000110125665apr DF, acórdão: 156576, órgão julgador: $2^{\mathrm{a}}$ turma criminal, data: 23/05/2002, Relator: Vaz de Mello, Diário da Justiça do DF: 07/08/2002 Pág: 98, cuja ementa ora transcrevemos parcialmente: "O DELITO PREVISTO NO ARTIGO 186, INCISO VI DA LEI FALIMENTAR, EXIGE NÃO SÓ A COMPROVAÇÃO DO ATRASO NA ESCRITURAÇÃO DOS LIVROS OBRIGATÓRIOS, OU QUE SEJA ESTA LACUNOSA, DEFEITUOSA, OU AINDA, A INEXISTÊNCIA DOS LIVROS COMERCIAIS OBRIGATÓRIOS. É NECESSÁRIO TAMBÉM GUARDAR RELAÇÃO COM A QUEBRA (CONDIÇÃO DE PUNIBILIDADE DO CRIME FALIMENTAR), COEXISTINDO COM ELA. O COMERCIANTE É OBRIGADO A TER SEUS LIVROS COMERCIAIS E FISCAIS REGISTRADOS NA JUNTA COMERCIAL, ALÉM DE MANTER A ESCRITURACÃO DELES DE FORMA CLARA E UNIFORME, CONSERVANDO EM BOA GUARDA TODA A ESCRITURACÃO. O APELADO ALEGOU TER ENTREGUE TODOS OS LIVROS DA EMPRESA. NÃO PRODUZIDA PELA ACUSAÇÃO A PROVA PLENA, INDISPENSÁVEL À CARACTERIZAÇÃO DO DELITO EM TELA, DEVE PREVALECER A DECISÃO ABSOLUTÓRIA QUANTO A ESTE CRIME. POR OUTRO LADO, O CONJUNTO PROBATÓRIO CARREADO AOS AUTOS NÃO DEIXA DÚVIDAS QUANTO A DISSOLUÇÃO IRREGULAR DA SOCIEDADE REALIZADA PELO ACUSADO, COM O INTUITO DE OBTER VANTAGENS. A SOCIEDADE FALIDA AO ENCERRAR SUAS ATIVIDADES SEM PROVIDENCIAR A BAIXA NOS REGISTROS DA JUNTA COMERCIAL, ALÉM DE NÃO TEREM SIDO ENCONTRADOS BENS OU DIREITOS A SEREM ARRECADADOS, ACARRETOU EFETIVO PREJUÍZO AOS CREDORES. A CONDUTA ESTATUÍDA NO ARTIGO 187 DA REFERIDA LEI NÃO EXIGE A OCORRÊNCIA DE EFETIVO PREJUÍZO AOS CREDORES, SENDO SUFICIENTE A SIMPLES POSSIBILIDADE DE SUA INCIDÊNCIA. IN CASU, O PREJUÍZO RESTOU EVIDENTE DIANTE DA NÃO LOCALIZAÇÃO DO PATRIMÔNIO DA FALIDA. A INTERDIÇÃO PARA O EXERCÍCIO DO COMÉRCIO CONSTITUI EFEITO DA CONDENAÇÃO POR CRIME FALIMENTAR. CONSIDERANDO-A PENA ACESSÓRIA, NÃO SE ACHA REVOGADA E NÃO PODE SER CONFUNDIDA COM A RESTRITIVA DE DIREITOS DO ARTIGO 47, INCISO II DO CÓDIGO PENAL, SENDO PERFEITAMENTE CABÍVEL NA ESPÉCIE. REJEITADA A PRELIMINAR E NEGADO PROVIMENTO AOS RECURSOS. UNÂNIME".
} 
Isso porque o legislador falimentar deseja a maior amplitude possível de informações aos credores e à sociedade como um todo a respeito do falido; as quais poderão constar de livros comerciais ou mesmo daqueles exigidos pela legislação tributária. Deseja-se saber, além das informações comerciais gerais, também o montante das dívidas tributárias do falido, as causas de sua existência, sua natureza, forma, etc.

No entanto, e até pela amplitude das informações desejadas na falência, não pode a legislação tributária simplesmente dispensar a escrituração que a legislação comercial entendeu indispensável à consecução de seus fins, colocando em seu lugar um pequeno número de informações contábeis relevantes ${ }^{33}$. Fosse isso possível, poder-se-ia privar os credores e os demais interessados na falência de dados imprescindíveis à consecução de seus fins.

Daí por que entendemos que a dispensa de escrituração somente poderá ser feita pela própria legislação comercial, que poderá desobrigar uma determinada categoria de empresários de escriturar, conforme determine sua conveniência.

$\mathrm{Na}$ esteira do raciocínio aqui desenvolvido, estariam as microempresas e as empresas de pequeno porte dispensadas de escrituração comercial completa por força do art. $1.179, \S 2^{\circ}$, do Código Civil, uma vez que o legislador teve por bem desobrigá-las de referida atividade, considerando a diminuta estrutura do negócio e a possível facilidade de obtenção de informações por outros meios.

Veja-se que várias decisões jurisprudenciais posteriores à Lei n. 9.317/96 acolhem o ponto de vista aqui exposto, mesmo tendo referida legislação (tributária) dispensado a escrituração. Nesse sentido:

\footnotetext{
${ }^{33}$ Dizemos isso em virtude de que os livros Caixa e Registro de Inventário somente demonstrarão a movimentação financeira (incluindo contas bancárias) e uma parte do ativo circulante. Poderá não haver informações suficientes neles lançadas a respeito de várias contas imprescindíveis, e.g. receita de vendas ou prestação de serviços (a receber), despesas operacionais já incorridas mas ainda não pagas, capital, reservas, obrigações passivas, etc.
} 


\section{Tribunal de Justiça de São Paulo}

\section{E M E N T A}

CRIME FALIMENTAR - Artigo 186, VI do Decreto-lei n. 7.661/45 - Não apresentação do livro diário - Empresa individual - Lei n. 7.256/84 Dispensa da escrituração - Inocorrência - Fato posterior à Lei n. 8.864/94 Escrituração contábil obrigatória - Ordem denegada. (Habeas Corpus n. 251.917-3 - Ribeirão Preto - $2^{\mathrm{a}}$ Câmara Criminal - Relator: Ângelo Gallucci - 06.04 .98 - V. U.)

\section{Tribunal de Justiça de São Paulo}

E M E N T A

CRIME FALIMENTAR - Artigos 186, VI e 188, III ambos da Lei de Falências - Ausência de falta de registro no livro obrigatório e desvio de bens da marca - Livro "diário" obrigatório para qualificar tipo de comércio, inclusive micro-empresa - Nenhum bem móvel arrecadado - Condenação mantida - Recurso não provido. (Apelação Criminal n. 241.367-3 - São Paulo - $1^{\mathrm{a}}$ Câmara Criminal - Relator: Andrade Cavalcanti - 16.02.98 - V. U.)

\section{Tribunal de Justiça de Minas Gerais}

\section{E M E N T A}

EMENTA: Crime Falimentar - Trancamento da ação penal - Microempresa - Dispensa legal de manter os livros de escrituração. Com o advento da Lei $\mathrm{n}^{\circ}$ 8.864/94, tornou-se dever do microempresário, assim como do empresário de pequeno porte, manter, ainda que de forma simplificada, a escrituração contábil da empresa, fazendo cessar a alegada dispensa. Obrigatoriedade de manter regularmente escriturados dois livros caixa e o do registro de inventário - Artigo $7^{\circ}$ da Lei $n^{\circ}$ 9.317/96. HABEAS CORPUS (C. CRIMINAIS ISOLADAS) $\mathrm{N}^{\circ}$ 000.264.955-6/00 - COMARCA DE 


\title{
BELO HORIZONTE - PACIENTE(S): JOÃO BAPTISTA DE PAULA MESQUITA NETO - COATOR(ES): JD 5 V CR COM. BELO HORIZONTE - RELATOR: EXMO. SR. DES. MERCÊDO MOREIRA
}

Decisão interessante sobre o tema em análise foi proferida pelo Tribunal de Justiça de São Paulo, na qual, reconhecendo a ausência de dolo do empresário e a ausência de boa orientação pelo profissional de contabilidade, veio a absolver os acusados por crime falimentar, sócios de microempresa não optante do sistema SIMPLES, mas tributada pelo lucro presumido.

\section{Tribunal de Justiça de São Paulo}

\begin{abstract}
E M E N T A
CRIME FALIMENTAR - Inexistência do Livro "Diário" - Pretendida absolvição - Admissibilidade - Réus que foram mal orientados pelo contador - Afirmação deste de que tratava-se de microempresa sob o sistema de lucro presumido - Ausência de dolo - Absolvição decretada Recurso provido. Quanto mais anormais as circunstâncias concomitantes, mais tênue a culpabilidade; em certos casos, esta anormalidade pode ser tão decisiva que o agente já não lhe é possível, em termos gerais, adequar-se às prescrições do ordenamento; nestas hipóteses, não lhe poderá ser feita nenhuma censura, posto que não cabe exigir-lhe uma conduta distinta. (Apelação Criminal n. 212.620-3 - Serra Negra - $1^{\mathrm{a}}$ Câmara Criminal Relator: Andrade Cavalcanti - 23.09.96 - V. U.).
\end{abstract}

Vê-se, portanto, que a legislação tributária, embora aparentemente tenha se imiscuído em matéria inerente ao Direito Comercial, não teve o condão de dispensar a obrigatoriedade de escrituração de modo que isente a incidência de crimes falimentares pela omissão dos livros e documentos obrigatórios exigidos. 


\subsubsection{Dispensa de escrituração e concordata ou recuperação de empresa}

Considerando os pressupostos legislativos até aqui analisados, cabe discutir agora se a legislação tributária teria o condão de afastar a obrigatoriedade de escrituração comercial para os fins de concordata, recuperação judicial ou extrajudicial.

A resposta afirmativa concluiria pela obrigação de as sociedades empresárias abrangidas pela dispensa escriturarem meramente os livros Caixa e Registro de Inventário, apresentando-os tão-somente em juízo para obtenção dos benefícios supracitados. A negativa refutaria tal solução, mantendo a obrigatoriedade para os mesmos fins.

Esse é um campo assaz delicado, uma vez que as decisões judiciais a respeito, por vezes, buscam evitar o formalismo exagerado, com vistas a buscar o princípio da preservação da empresa, a que visam os institutos da concordata e da recuperação.

Da mesma forma, poderemos verificar pela análise da legislação anterior (Dec.-Lei n. 7.661/45) e atual (Lei n. 11.101/05) que houve certa mudança nas exigências escriturais, pelo menos em relação às microempresas e empresas de pequeno porte.

Com efeito o Dec.-Lei n. 7.661/45, em seu art. $159, \S 1^{\circ}$, preceituava:

$\S 1^{\circ}$ A petição será instruída com os seguintes documentos:

IV - demonstrações financeiras referentes ao último exercício social e as levantadas especialmente para instruir o pedido, confeccionadas com estrita observância da legislação societária aplicável e composta obrigatoriamente de: 


\begin{abstract}
a) balanço patrimonial;
b) demonstração de lucros ou prejuízos acumulados;

c) demonstração do resultado desde o último exercício social;

$V$ - inventário de todos os bens e a relação das dívidas ativas;
\end{abstract}

Certamente, perante a legislação anterior seria verdadeiramente difícil, ou quase incompatível com o pedido de concordata, a escrituração parcial da atividade econômica, uma vez que as demonstrações exigidas pela então lei falimentar obrigavam a concordatária a manter suas obrigações escriturais com a maior extensão possível.

Como já ressaltamos, a dispensa seria admissível por efeito da legislação comercial, como o fez a Lei n. 7.256/84 (art. 15) ${ }^{34}$. Resta saber os efeitos da legislação tributária na matéria.

Nos termos da legislação falimentar anterior (Dec.-Lei n. 7.661/45), ressalvadas as dispensas específicas para as microempresas por seus estatutos de regência, entendemos que tanto referida categoria de empresários como aqueles tributados com base no lucro presumido não adquiriram qualquer dispensa de escrituração.

Nesse sentido, decisões existem:

\footnotetext{
${ }^{34}$ Várias foram as decisões que dispensaram microempresários de exibir escrituração completa em pedidos de concordata. Citamos aqui apenas uma delas, do Tribunal de Justiça de São Paulo: "CONCORDATA PREVENTIVA - Microempresa - Livro Diário - Exibição - Manutenção não obrigatória - Necessidade do arquivamento de documentos - Exigência de exibição ilegal - Segurança concedida. Em se cuidando de concordata preventiva, de microempresa, o rigor quanto aos documentos que devem instruir o pedido é mitigado pela Lei 7.256/84, que aboliu a escrituração mercantil, obrigando, tão somente ao arquivamento de documentos". (Mandado de Segurança n. 266.145-1 - São Paulo - $6^{\text {a }}$ Câmara Civil - Relator: Aclibes Burgarelli - 05.10.95 - V.U.)
} 


\section{Tribunal de Justiça de São Paulo}

E M E N T A

CONCORDATA PREVENTIVA - Convolação em falência -

Admissibilidade - Hipótese de não preenchimento dos requisitos necessários para o favor legal - Aplicabilidade também às microempresas - Ocorrência, ademais, de outras irregularidades ensejando a falência - Decisão que se mantém - Recurso não provido. Quando a pretendente do favor da concordata não apresenta os livros contábeis, nem os balanços anuais, ou o especial para o pedido e ainda, acima de tudo, tem inúmeros títulos protestados, deixando de apresentar tais documentos por longo espaço de tempo, pelo juiz concedido, merece apenas, que se lhe decrete a quebra, não obstante, tratar-se de microempresa, pois não está desobrigada de tais exigências - Falência decretada. (Agravo de Instrumento n. 100.727-4 - São Paulo - $7^{\mathrm{a}}$ Câmara de Direito Privado - Relator: Oswaldo Breviglieri 22.02 .99 - V. U.).

\section{Tribunal de Justiça de Minas Gerais}

AGRAVO No 52.574/1 - COMARCA DE ELÓI MENDES AGRAVANTE - C. A. PETRONE \& CIA. LTDA. - AGRAVADO - JD COMARCA ELÓI MENDES - RELATOR - EXMO. SR. DES. CORRÊA DE MARINS.

\section{A C Ó R D Ã O}

Vistos etc., acorda, em Turma, a Quarta Câmara Cível do Tribunal de Justiça do Estado de Minas Gerais, incorporando neste o relatório de fls., na conformidade da ata dos julgamentos e das notas taquigráficas, à unanimidade de votos, EM NEGAR PROVIMENTO. Belo Horizonte, 29 de fevereiro de 1996. DES. FRANCISCO FIGUEIREDO - Presidente. DES. CORRÊA DE MARINS - Relator. NOTAS TAQUIGRÁFICAS O SR. DES. CORREAA DE MARINS: 


\section{VOTO}

Conheço do recurso, por força do art. 162, $\S 2^{\circ}$, da Lei $n^{\circ} 7.661 / 45$. Insurgese a recorrente contra a $r$. sentença que lhe decretou a falência, em autos de Pedido de Concordata Preventiva. Alega haver cumprido todos os prérequisitos necessários ao pedido, injustificando-se a r. decisão monocrática. Mas, a meu juízo, a r. sentença imerece qualquer reforma, eis que balizada nos contornos da Lei de Falências, que rege a espécie. Desatendidos os pressupostos do pedido levado à apreciação do Judiciário, ainda que instado pelo juízo, por liberalidade, em derradeira oportunidade, outra não poderia ser a decisão singular, senão a que se acha inserida nos autos, contra a qual se insurge o clamor recursal. A exigência do juízo acha-se inserida entre as obrigações atribuídas ao concordatário, e alegação de que a agravante apura resultados pelo sistema do lucro presumido atinge apenas os livros fiscais, o que não o desobriga da escrituração dos livros contábeis. Assim, a exigência do livro Diário, que sequer é cristalinamente dispensado às microempresas, conforme bem esclarece a douta Procuradoria Geral de Justiça, no bem lançado parecer de sua Procuradora Ana Ivanete dos Santos, jamais poderia ter sido dispensada pelo juízo, nas atuais circunstâncias.

O decreto de falência, assim, se justifica não só pela inapresentação de referido livro obrigatório, como também pelos demais documentos não oferecidos junto ao pedido de concordata, conforme faz claro o exame dos autos. Nesta conformidade, NEGO PROVIMENTO ao recurso. Custas ex lege. PARTICIPARAM DO JULGAMENTO os Desembargadores Alves de Melo e Francisco Figueiredo. SÚMULA: NEGARAM PROVIMENTO.

Perante o novel ordenamento falimentar, as exigências para a recuperação judicial e extrajudicial (a seguir transcritas) não fazem qualquer exceção às empresas tributadas no sistema de lucro presumido. Em relação às microempresas, porém, há dispositivo específico.

Art. 51. A petição inicial de recuperação judicial será instruída com: 
II - as demonstrações contábeis relativas aos 3 (três) últimos exercícios sociais $e$ as levantadas especialmente para instruir o pedido, confeccionadas com estrita observância da legislação societária aplicável e compostas obrigatoriamente de:

a) balanço patrimonial;

b) demonstração de resultados acumulados;

c) demonstração do resultado desde o último exercício social;

d) relatório gerencial de fluxo de caixa e de sua projeção;

$\S 1^{\circ}$ Os documentos de escrituração contábil e demais relatórios auxiliares, na forma e no suporte previstos em lei, permanecerão à disposição do juízo, do administrador judicial e, mediante autorização judicial, de qualquer interessado.

$\S 2^{\circ}$ Com relação à exigência prevista no inc. II do caput deste artigo, as microempresas e empresas de pequeno porte poderão apresentar livros $e$ escrituração contábil simplificados nos termos da legislação específica.

$\S 3^{\circ}$ O juiz poderá determinar o depósito em cartório dos documentos a que se referem os $\$ \S 1^{o}$ e $2^{o}$ deste artigo ou de cópia destes.

Verifica-se que as microempresas e as de pequeno porte obtiveram simplificação ou dispensa parcial de escrituração, nos termos de sua legislação própria.

Assim, em princípio seria admissível dizer que a legislação falimentar se reportou à legislação tributária que rege as obrigações escriturais das microempresas e empresas de pequeno porte, para exigir delas apenas a apresentação dos livros exigidos neste ordenamento específico. 
Essa é a opinião da Prof ${ }^{a}$ Raquel Sztajn, que, em comentário ao dispositivo legal, ressalta, com importantes ponderações, que "O parágrafo seguinte excepciona, facultando que microempresas e empresas de pequeno porte, no que concerne aos documentos do inc. II, sigam as normas fiscais e não as societárias quanto à sua apresentação. A excepcionalidade de que gozam quanto às obrigações fiscais se reflete na escrituração mercantil, que é também simplificada. Quando o cálculo de impostos é feito sobre o faturamento ou sobre o rendimento presumido, supõe-se que os controles gerenciais possam ser relaxados, o que não corresponde à realidade. Controles gerenciais e tributação não se confundem, cada um deles tem função determinada. Controle gerencial mede a eficiência e eficácia das ações administrativas; controle fiscal é instrumento de imposição tributária com finalidade arrecadatória. Portanto, se a escrituração pode ser 'menos complexa', é porque as operações são mais simples”35.

A única legislação que impõe, em termos concretos, deveres escriturais é a Lei n. 123/06 (que revogou a Lei n. 9.317/96), a qual regula a tributação das microempresas e empresas de pequeno porte, uma vez que a Lei n. 8.864/94 e a Lei n. 9.841/99 (também revogada pela Lei Complementar n. 123/06) não trataram do tema de forma específica.

O Tribunal de Justiça de São Paulo, na vigência da Lei n. 9.137/96, seguiu essa orientação, admitindo a apresentação única dos livros fiscais em juízo:

\section{Tribunal de Justiça de São Paulo}

RECUPERAÇÃO DE EMPRESA - Judicial - Microempresa - Empresa optante do regime "SIMPLES" - Ausência de apresentação do livro diário Validade da sua substituição pelo livro caixa - Requisito legal para concessão da concordata presente - Instituto que visa salvar a empresa e conseqüentemente, a manutenção da atividade - Decreto de falência afastado, determinado o processamento da concordata

\footnotetext{
${ }^{35}$ Observação inserida na obra: Comentários à Lei de recuperação de empresas e falência: Lei 11.101/2005. Coordenação: Francisco Satiro de Souza Júnior, Antônio Sérgio A. de Moraes Pitombo. São Paulo: Editora Revista dos Tribunais, 2005. p. 256.
} 
preventiva/recuperação judicial em prol da agravante - Recurso provido para esse fim. (Agravo de Instrumento n. 397646-4/4-00 - São Paulo - $3^{\text {a }}$ Câmara de Direito Privado - 11/10/2005 - Rel. Élcio Trujillo - V. U. - V. 1780).

No inteiro teor do acórdão supracitado, temos a seguinte lição: “A decisão comporta reforma. A agravante, no regime do 'SIMPLES' conta com tratamento diferenciado no campo fiscal e documental, válida a substituição do livro diário pelo livro caixa, devidamente entregue, de forma a cumprir o requisito legal para a concessão da concordata".

Tal decisão, no entanto, já se encontra superada pela legislação que atualmente regula a matéria.

De fato, nos termos da Lei Complementar n. 123/06, a microempresa ou empresa de pequeno porte terá três implicações em sua escrituração: 1) estará dispensada da escrituração mercantil, por força do que dispõe o Código Civil; 2) se for optante do Simples, estará desobrigada da escrituração fiscal, devendo apresentar no juízo falimentar ou de recuperação meramente os documentos relacionados às receitas operacionais e aqueles que fundamentaram exigências tributárias; 3) se não optante pelo Simples, deverá apresentar em juízo livro Caixa.

\subsubsection{Dispensa de escrituração e ações de prestação de contas ou exibição judicial}

O tema que passamos a abordar diz respeito proximamente à questão da eficácia probatória dos livros comerciais, a qual será examinada com mais vagar posteriormente. 
Cumpre agora apenas saber se a legislação tributária, tornando dispensável a escrituração comercial para as microempresas, empresas de pequeno porte ou às tributadas pelo lucro presumido, veio a desobrigar referidas categorias de apresentar escrituração completa (livro Diário) quando exigidas judicialmente em ações de prestação de contas ou exibição judicial (esta como ação principal ou como meio de prova em outra ação).

Da mesma forma, o art. 915 do CPC, mandando aplicar ao caso daquele que, sendo obrigado, não presta as contas exigidas, o art. 330 deste último diploma legal (revelia a julgamento antecipado da lide), dispõe que:

Art. 915 - Aquele que pretender exigir a prestação de contas requererá a citação do réu para, no prazo de 5 (cinco) dias, as apresentar ou contestar a ação.

$\S 2^{o}$ - Se o réu não contestar a ação ou não negar a obrigação de prestar contas, observar-se-á o disposto no art. 330; a sentença, que julgar procedente a ação, condenará o réu a prestar as contas no prazo de 48 (quarenta e oito) horas, sob pena de não lhe ser lícito impugnar as que o autor apresentar.

Saliente-se que, por força do art. 917 do Código de Processo Civil, as contas deverão ser apresentadas em forma mercantil, especificando-se as receitas e a aplicação das despesas, bem como o respectivo saldo; e serão instruídas com os documentos justificativos.

Da mesma forma, nos termos de nossa legislação processual (Código de Processo Civil), tem-se que o efeito da ausência de exibição de documento ou coisa, sendo inadmissível a recusa, será a presunção de veracidade dos fatos alegados pela parte contrária.

Dispõem os arts. 358 e 359 do CPC: 
Art. 358 - O juiz não admitirá a recusa:

I - se o requerido tiver obrigação legal de exibir;

II - se o requerido aludiu ao documento ou à coisa, no processo, com o intuito de constituir prova;

III - se o documento, por seu conteúdo, for comum às partes.

Art. 359 - Ao decidir o pedido, o juiz admitirá como verdadeiros os fatos que, por meio do documento ou da coisa, a parte pretendia provar:

I - se o requerido não efetuar a exibição, nem fizer qualquer declaração no prazo do art. 357;

II - se a recusa for havida por ilegítima.

No que diz respeito à prestação de contas, podemos dizer que mesmo a dispensa de escrituração efetivada pela legislação às microempresas e empresas de pequeno porte não tem o condão de eximi-las de referido dever nos casos legais.

Isso porque, para que sejam prestadas contas em juízo, que normalmente dizem respeito a aspectos específicos da atividade econômica, não é necessária prévia e completa escrituração, bastando que seja esta elaborada para o caso concreto no ponto específico exigido. Considerando que, mesmo no caso das dispensas legalmente estabelecidas, as microempresas e empresas de pequeno porte restaram obrigadas a guardar a documentação das transações efetivadas (art. 15 da Lei n. 7.256/84 e art. 12, parágrafo único, da Lei n. 8.864/94), será sempre possível a prestação de contas.

Aliás, essa é a interpretação jurisprudencial:

\section{Tribunal de Justiça de São Paulo}

PRESTAÇÃO DE CONTAS - Microempresa - Dispensa de escrituração Inadmissibilidade - Inteligência dos artigos 15 da Lei n. 7.256/84 e 12 da 
Lei n. 8.864/94 - Dever de conservação dos documentos comprobatórios das operações - Recurso não provido. A dispensa, às microempresas, de manter escrituração, não as isenta de conservar os documentos relativos às compras, vendas e serviços que realizarem. (Relator: Marrey Neto - Agravo de Instrumento n. 244.230-2 - São Paulo - 16.08.94).

\section{Tribunal de Justiça de São Paulo}

PRESTAÇÃO DE CONTAS - Microempresa - Artigo 917 do Código de Processo Civil - Aplicabilidade - Inobservância - Acolhimento do laudo oficial, elaborado com os dados e documentos disponíveis - Recurso não provido. JTJ 179/112

\section{Tribunal de Justiça de São Paulo}

PRESTAÇÃO DE CONTAS - Microempresa - Apresentação pura e simplesmente de saldos anuais, sem qualquer comprovação - Insuficiência Obrigatoriedade de apresentá-las na forma mercantil, instruídas com documentos justificativos de suas operações - Artigos 917 do Código de Processo Civil, 15 da Lei Federal $n^{\circ} 7.256$, de 1984, e 12 da Lei Federal $n^{\circ}$ 8.864, de 1994 - Perícia contábil determinada - Artigo 915, § 3º "in fine", do referido Código - Recurso não provido JTJ 162/198.

O mesmo raciocínio é aplicável às sociedades tributadas com base no lucro presumido.

Quanto à exibição judicial dos livros, entendemos, seguindo a linha já exposta anteriormente, que as microempresas, empresas de pequeno porte e aquelas tributadas com base no lucro presumido deverão apresentar a escrituração exigida pela legislação comercial, restringindo-se as dispensas efetivadas pela legislação tributária para fins exclusivamente fiscais. 
Assim pensamos diante da dicção dos dispositivos da legislação processual civil quanto à exibição judicial dos livros, como medida principal, preparatória ou mesmo como meio de prova.

Se bem observarmos o que determina o Código de Processo Civil, veremos que referida legislação faz referência sempre a livros comerciais e escrituração comercial; nunca à escrituração fiscal. Reporta-se, portanto, a lei processual ao ordenamento de Direito Comercial, e não ao congênere tributário.

Nesses termos, vejamos o que diz o CPC (grifos nossos):

Art. 381 - O juiz pode ordenar, a requerimento da parte, a exibição integral dos livros comerciais e dos documentos do arquivo:

I - na liquidação de sociedade;

II - na sucessão por morte de sócio;

III - quando e como determinar a lei.

Art. 382 - O juiz pode, de ofício, ordenar à parte a exibição parcial dos livros e documentos, extraindo-se deles a suma que interessar ao litígio, bem como reproduções autenticadas.

Art. 844 - Tem lugar, como procedimento preparatório, a exibição judicial:

III - da escrituracão comercial por inteiro, balanços e documentos de arquivo, nos casos expressos em lei.

Dessa forma, requerida a exibição da escrituração em juízo, deverá a parte de quem se exigiu tal providência exibir, no todo ou em parte, a escrituração que lhe 
determinar a lei comercial, sendo inoperantes para tais fins as dispensas da legislação tributária.

\subsubsection{Dispensa de escrituração e demonstrativos contábeis}

Há mais uma séria conseqüência que poderia derivar da dispensa, pela legislação tributária, da escrituração comercial completa. Esta se refere aos demonstrativos contábeis, dos quais fazem parte o balanço, a demonstração de resultados de exercício, a demonstração de lucros e prejuízos, a demonstração de origens e aplicações de recursos, entre outras.

De fato, se entendermos como incidente a dispensa antes mencionada, com a exigência subsidiária dos livros Caixa e Registro de Inventário, teremos uma escrituração parcial das atividades econômicas empresariais.

Isso porque, como já salientamos, a escrituração dos livros acima mencionados oferece um controle de apenas algumas contas, quais sejam daquelas relativas às disponibilidades (caixa, contas bancárias, aplicações financeiras, etc.) e de parte do ativo permanente (estoque, etc.). Não contêm, em regra, informações sobre passivo, patrimônio líquido e seus componentes, ativo permanente, entre outras mais.

Dessa forma, sendo os demonstrativos contábeis consequiências imediatas de uma escrituração completa, será corolário imediato da dispensa de escrituração a inexigibilidade da elaboração dos primeiros. Não haverá como se exigir a elaboração, e.g., de um balanço, para uma determinada sociedade que nem sequer está obrigada a escriturar seu passivo.

E não é só. 
Em regra, os demonstrativos são inseridos ao final e em conjunto com a escrituração completa (livro Diário), como bem se verifica no art. 1.184, § $2^{\circ}$, do Código Civil $^{36}$ (recebendo, juntamente com o livro, a autenticação do órgão de Registro de Empresas respectivo), podendo, conforme o caso, serem publicadas (art. 176, da Lei n. 6.404/76).

Se admitirmos que uma determinada sociedade só escriture livros Caixa e Registro de Inventário, não haverá razão sequer para a obrigatoriedade de demonstrativos contábeis, pois não terão a necessidade de constar dos livros citados (e com eles receber a autenticação devida) ou mesmo serem publicados.

Restariam os demonstrativos, se fosse o desejo do empresário elaborá-los, como mero instrumento interno para fins gerenciais.

Certamente não foi essa a orientação do legislador, até mesmo porque teríamos de admitir, fosse esse o caso, a parcial revogação do art. 1.184 do Código Civil.

Daí por que concluímos, novamente, que as dispensas da legislação tributária não operam efeitos em relação às obrigações estatuídas na legislação comercial. Para as microempresas e empresas de pequeno porte, a dispensa estatuída no Código Civil (art. 1.179, $\S 2^{\circ}$ ) faz com que estas também estejam, em regra, dispensadas de formular seus demonstrativos contábeis. Nenhuma escusa, entretanto, haverá em relação às empresas tributadas com base no lucro presumido.

${ }^{36} \S 2^{\circ}$ Serão lançados no Diário o balanço patrimonial e o de resultado econômico, devendo ambos ser assinados por técnico em Ciências Contábeis legalmente habilitado e pelo empresário ou sociedade empresária. 


\section{A SOCIEDADE LIMITADA E A SOCIEDADE ANÔNIMA}

Considerando que o presente trabalho tratará sobre a escrituração das sociedades anônimas e limitadas, nada mais natural que fazermos aqui uma pequena introdução de referidos tipos societários, com as distinções específicas inerentes a cada qual, principalmente no que tange aos aspectos inerentes à escrituração.

Referidos tipos societários se assemelham em um aspecto básico, qual seja, a limitação da responsabilidade subsidiária do sócio pelas dívidas sociais. Este, aliás, foi o propósito básico da existência dessas sociedades e uma das razões do sucesso que atingiram.

Com efeito, a idéia basilar por trás da criação das sociedades anônimas e limitadas é a de que os sócios que investirem seu capital em um determinado empreendimento cuja forma adotada seja a de um dos tipos referidos, não terá, caso a empreitada venha a fracassar, um prejuízo maior do que o montante dos recursos investidos.

Essa limitação pressupõe que os prejuízos que superarem o valor do investimento serão suportados pelos credores e demais pessoas componentes da sociedade como um todo. Muito embora possa parecer injusto em princípio, a limitação da responsabilidade do sócio é um incentivo ao empreendedorismo, atividade sem a qual a moderna sociedade não pode subsistir e progredir economicamente. ${ }^{37}$

Apesar de se aproximarem no que diz respeito à limitação da responsabilidade subsidiária dos sócios, aí também se encontra a principal distinção entre as limitadas e as anônimas, pois enquanto nas primeiras os sócios respondem

\footnotetext{
${ }^{37}$ Nesse sentido é também a opinião de Fábio Ulhoa Coelho: "Justifica-se a sistemática de submeter as perdas dos sócios ao limite do investimento, transferindo o prejuízo para os credores da sociedade, na medida em que ao direito positivo cabe, por meio do controle dos riscos, motivar os empreendedores na busca de novos negócios" (Curso de Direito Comercial. São Paulo: Saraiva, 2003. v. 2, p. 28).
} 
solidariamente pelo montante do capital ainda não integralizado, nas segundas o acionista somente responde pelo que resta a integralizar do preço de emissão das ações por ele adquiridas.

Logo, um acionista não será responsável pela não integralização do preço de emissão das ações de um outro congênere, o que, de maneira similar, poderá ocorrer com um sócio de sociedade por cotas de responsabilidade limitada.

É bem verdade que a limitação referida, tanto nas anônimas como nas limitadas, vem sofrendo sérias restrições, fundamentadas muitas vezes no uso fraudulento da personalidade jurídica para atingir fins vedados pelo ordenamento jurídico em prejuízo de terceiros. Isso é muito presente no caso de credores não negociais (trabalhadores, fisco, consumidores), hipótese em que o instituto da desconsideração da personalidade jurídica vem sendo aplicado com maior freqüência e rigor.

Outras distinções existem. Sob o ponto de vista da escrituração (objeto deste trabalho), como veremos com maiores detalhes no decorrer do texto, as distinções entre sociedades anônimas e as sociedades por cotas de responsabilidade limitada são flagrantes, principalmente quando se trata de sociedade anônima de capital aberto.

Por representar ordinariamente um volume superior de investimentos ou ter de captar recursos públicos (caso da companhia aberta), a sociedade anônima tem de prestar um conjunto de informações contábeis ao público muito maior que o exigido das sociedades limitadas. Para os efeitos de escrituração, as principais diferenças entre os dois tipos societários são demonstradas a seguir: 
Quadro 4: distinções entre as sociedades anônimas e limitadas quanto à escrituração

\begin{tabular}{|c|c|c|}
\hline & Sociedade anônima & Sociedade limitada \\
\hline $\begin{array}{c}\text { Livros } \\
\text { obrigatórios }\end{array}$ & $\begin{array}{c}\text { Livros comerciais gerais: } \\
\text { Diário }^{38} \\
\text { Específicos: Registro de } \\
\text { Duplicatas, Atas de } \\
\text { assembléias gerais, Atas e } \\
\text { Pareceres do Conselho } \\
\text { Fiscal, Atas das Reuniões da } \\
\text { Diretoria. Presença dos } \\
\text { Acionistas, Registro de } \\
\text { Ações Nominativas, } \\
\text { Transferências de Ações } \\
\text { Nominativas. }\end{array}$ & $\begin{array}{l}\text { Livros comerciais } \\
\text { gerais: Diário. } \\
\text { Específicos: Registro } \\
\text { de Duplicatas. }\end{array}$ \\
\hline $\begin{array}{l}\text { Demonstrações } \\
\text { contábeis } \\
\text { obrigatórias }\end{array}$ & $\begin{array}{c}\text { Necessitam elaborar as } \\
\text { seguintes demonstrações: } \\
\text { I - balanço patrimonial; } \\
\text { II - demonstração dos } \\
\text { lucros ou prejuízos } \\
\text { acumulados (ou } \\
\text { demonstração de mutações } \\
\text { no patrimônio líquido); } \\
\text { III - demonstração do } \\
\text { resultado do exercício; e } \\
\text { IV - demonstração de } \\
\text { fluxo de caixa (dispensadas } \\
\text { no caso de ser companhia } \\
\text { fechada, com patrimônio } \\
\text { líquido, na data do } \\
\text { balanço, não superior a R\$ } \\
2.000 .000,00) ; \text { e } \\
\text { V - demonstração do valor } \\
\text { adicionado, se companhia }\end{array}$ & $\begin{array}{c}\text { As demonstrações } \\
\text { referentes ao balanço } \\
\text { patrimonial e à } \\
\text { demonstração de } \\
\text { resultado do } \\
\text { exercício }^{39} \text { serão } \\
\text { lançadas no Diário. }\end{array}$ \\
\hline
\end{tabular}

\footnotetext{
${ }^{38}$ Se submetidas ao regime de lucro real, para efeito de imposto sobre a renda, tanto a sociedade limitada quanto a anônima terão por obrigatório, como livro fiscal, espécie que comumente fora tratada pela doutrina como livro comercial, qual seja o livro Razão, por força da Lei n. 8.218, de 1991, art. 14, parágrafo único, e Lei n. 8.383, de 1991, art. 62.

${ }^{39}$ Veremos mais adiante que o Código Civil denomina a demonstração de resultados do exercício (DRE) de balanço de resultado econômico (art. 1.184, § $2^{\circ}$ ).
} 


\begin{tabular}{|c|c|c|}
\hline & aberta. & \\
\hline Publicações & $\begin{array}{l}\text { Necessitam publicar suas } \\
\text { demonstrações contábeis } \\
\left(\text { art. } 176, \S 1^{\circ} \text { da LSA }\right)^{40}\end{array}$ & $\begin{array}{l}\text { Não necessitam } \\
\text { publicar suas } \\
\text { demonstrações } \\
\text { contábeis }\end{array}$ \\
\hline $\begin{array}{l}\text { Necessidade de } \\
\text { auditoria } \\
\text { independente nas } \\
\text { demonstrações }\end{array}$ & $\begin{array}{l}\text { Necessitam de auditoria } \\
\text { independente se companhias } \\
\text { abertas, ou se de grande } \\
\text { porte (art. } 177, \S 3^{\circ} \text {, da Lei } \\
\text { n. } 6.404 / 1976 \text { e Lei n. } \\
11.638 / 07 \text {, art. } 3^{\circ} \text { ) }\end{array}$ & $\begin{array}{l}\text { Não necessitam, em } \\
\text { regra, de auditoria } \\
\text { independente, salvo } \\
\text { se sociedades de } \\
\text { grande porte (Lei } \\
\left.11.638 / 07 \text {, art. } 3^{\circ}\right)\end{array}$ \\
\hline $\begin{array}{l}\text { Submissão às } \\
\text { normas da } \\
\text { Comissão de } \\
\text { Valores } \\
\text { Mobiliários } \\
\text { (CVM) }\end{array}$ & $\begin{array}{l}\text { Submetem-se às normas da } \\
\text { CVM, se companhias de } \\
\text { capital aberto (art. 177, } \S 3^{\circ} \\
\text { da LSA) }\end{array}$ & $\begin{array}{c}\text { Não necessitam, em } \\
\text { regra, observar as } \\
\text { normas da CVM, } \\
\text { devendo obedecer às } \\
\text { regras da Lei n. } \\
\text { 6.404/76 sobre } \\
\text { escrituração e } \\
\text { elaboração de } \\
\text { demonstrações } \\
\text { financeiras, com } \\
\text { auditoria por } \\
\text { profissional registrado } \\
\text { na CVM, se sociedades } \\
\text { de grande porte }(\text { Lei n. } \\
\left.\text { 11.638/07, art. } 3^{\circ}\right)\end{array}$ \\
\hline
\end{tabular}

Verifica-se, dessa forma, que as distinções existentes no tocante à escrituração dependerão não somente do que preceitua a legislação comercial, mas também do que disciplina a legislação tributária, que afasta, muitas vezes, a aplicação da primeira. Temos aí um primeiro indício, a se aprofundar posteriormente, de que a distinção entre escrituração fiscal e comercial já não se impõe de maneira tão decisiva quanto preceituava alguma doutrina.

\footnotetext{
${ }^{40}$ Nos termos do art. 294, II, da Lei n. 6.404/76 (com redação dada pela Lei n. 10.194, de 14.02.2001), a companhia fechada que tiver menos de vinte acionistas, com patrimônio líquido inferior a $R \$ 1.000 .000,00$ (um milhão de reais), poderá deixar de publicar os documentos de que trata o artigo 133, desde que sejam, por cópias autenticadas, arquivados no registro de comércio juntamente com a ata da assembléia que sobre eles deliberar.
} 


\section{ESCRITURAÇÃO NAS SOCIEDADES ANÔNIMAS}

A escrituração nas sociedades anônimas, como asseveramos anteriormente, serve de modelo para os tipos societários menores, particularmente, no caso das sociedades limitadas, cujo processo escritural será igualmente tratado neste trabalho.

O assunto é tratado particularmente no capítulo XV da Lei n. 6.404/76, sob a rubrica "Exercício Social e Demonstrações Financeiras". Para melhor estudar a matéria, dividimos os estudos respectivos conforme a separação patrimonial efetivada pela ciência contábil. O tema ainda será retomado mais adiante, particularmente quando tratarmos das demonstrações contábeis.

É relevante salientar que a legislação do anonimato passou recentemente por reforma com o advento da Lei n. 11.638/07, que efetivou ainda uma série de modificações na escrituração contábil das sociedades anônimas, as quais serão vistas mais adiante.

Seus objetivos principais foram:

- Harmonizar a legislação nacional com os padrões contábeis internacionais: a Lei n. 11.638/07, ao adicionar o $\S 5^{\circ}$ ao art. 177 da Lei $n$. 6.404/76, permitiu que a Comissão de Valores Mobiliários venha a criar normas para as sociedades anônimas, as quais estejam em consonância com os padrões internacionais de contabilidade adotados nos principais mercados de valores mobiliários. Os padrões contábeis internacionais mais adotados estão contidos principalmente nas normas internacionais de contabilidade (International Financial Reporting Standards - IFRS) emitidas pelo IASB (International Accounting Standards Board) ou aqueles usualmente aceitos nos Estados Unidos (US GAAP - United States Genneral Accepted 
Accounting Principles), emitidos pelo FASB (Financial Accounting Standards Board) ${ }^{41}$;

- Aumentar a transparência e o grau de informações ao usuário das demonstrações contábeis: vindo para tanto a obrigar a elaboração da demonstração de fluxos de caixa (DFC) em substituição à antiga demonstração de origens e aplicações de recursos (DOAR) e da demonstração de valor adicionado (DVA), para que os destinatários das informações financeiras das companhias abertas ou fechadas de maior porte venham a ter ciência das variações de numerário das entidades em análise, bem como da destinação própria de seus recursos;

- Apresentar novos critérios para classificação e valoração do ativo, de acordo com parâmetros internacionais: a Lei n. 11.638/07, como veremos mais adiante, inovou os critérios de classificação do ativo (criando a categoria de ativo intangível, antes inexistente), além de inovar nos critérios de valoração do ativo, adotando, para alguns itens que o compõem, o critério de valor de mercado, valor de realização, ou ainda o correspondente ao valor presente de fluxos de caixa futuros, em detrimento do registro pelo custo histórico. Obrigou também a análise periódica sobre valores registrados no imobilizado, diferido ou intangível.

Genericamente, as normas gerais de escrituração das sociedades anônimas estão consignadas no art. 177, com redação modificada pela Lei n. 11.638/07.

Os temas tratados no artigo supracitado já foram analisados anteriormente nesta dissertação, com algumas ressalvas que ora faremos.

É de se observar no caput do artigo um princípio contábil não contido no elenco da Resolução CFC 750/93, qual seja o princípio da uniformidade.

${ }^{41}$ A Instrução CVM n. 457/07 já obrigava as companhias abertas, a partir do exercício findo em 2010, a apresentar as suas demonstrações financeiras consolidadas adotando o padrão contábil internacional, de acordo com os pronunciamentos emitidos pelo International Accounting Standards Board - IASB. 
Segundo referido postulado, a escrituração deverá observar critérios uniformes no decorrer do tempo, uma vez que mudanças súbitas e não devidamente explicitadas poderão levar os usuários ou destinatários da escrituração a conclusões errôneas.

Exemplo clássico de problemas na uniformidade é o que ocorre com o sistema utilizado para a avaliação de estoques. Com efeito, em algumas atividades a sociedade será capaz de individualizar claramente os produtos adquiridos para revenda (objetos de seu estoque) por diversos meios (números de série, códigos de barra, etc.). Dessa forma, ao vendê-los, terá clara noção de seu custo de aquisição, podendo apurar eficazmente seu lucro, diminuindo do preço de venda do produto seu custo de aquisição.

Muitas vezes, entretanto, a sociedade poderá comercializar produtos cuja individualização entre os diversos lotes adquiridos não seja possível. Veja-se, por exemplo, o caso da comercialização de produtos a granel: como se saberá qual lote de grãos foi vendido ao cliente que adquiriu determinada quantia especificada apenas pela massa ou volume?

Para a solução de tal problema, foram criados alguns critérios contábeis para a avaliação de estoques, sendo que os principais são:

- PEPS ou FIFO (o primeiro que entra é o primeiro que sai ou first in first out): a empresa dará baixa em seu estoque pelas vendas utilizando o custo de aquisição dos primeiros lotes adquiridos em estoque;

- UEPS ou LIFO (o último que entra é o primeiro que sai ou last in first out): a empresa dará baixa em seu estoque pelas vendas utilizando o custo de aquisição dos últimos lotes adquiridos em estoque; 
- Média ponderada móvel: a empresa dará baixa em seu estoque pela venda utilizando o preço médio ponderado, calculado pela razão entre o custo total dos estoques e seu número de unidades ${ }^{42}$.

Obviamente, tais critérios poderão influenciar decisivamente no lucro da empresa. Sendo este obtido pela diferença entre o preço de venda e o custo de aquisição, é nítida a percepção de que, se a empresa utilizar o PEPS, irá avaliar seus estoques restantes (não vendidos) por preços normalmente maiores (os últimos lotes adquiridos, ainda não vendidos, normalmente têm preços superiores aos mais antigos), enquanto seus lotes vendidos serão avaliados por preços menores (pois serão os primeiros adquiridos).

Já se utilizar o UEPS ocorrerá justamente o inverso, reduzindo-se o lucro. Por derradeiro, se utilizar a média ponderada móvel, o lucro estará em um patamar intermediário entre os dois critérios.

A empresa, salvo algumas restrições legais, não está obrigada a utilizar um dos critérios acima citados. No entanto, ao utilizar um deles, deverá manter referido critério ao longo do tempo, cumprindo o princípio contábil da uniformidade, ressalvadas mudanças fundamentadas em notas explicativas (art. 177, § $1^{\circ}$ ), para não levar o destinatário da escrituração empresarial a erro.

Além da uniformidade, o art. 177 e seus parágrafos também tratam da divergência de critérios entre a legislação contábil e tributária (assunto tratado anteriormente), da necessidade de auditoria independente nas demonstrações (tema que trataremos mais adiante) e da obrigatoriedade da subscrição das demonstrações por contabilista legalmente habilitado (matéria que trataremos no capítulo referente às responsabilidades de referido profissional).

\footnotetext{
${ }^{42}$ Exemplo prático: suponhamos dois lotes: 1) 100 unidades a $\mathrm{R} \$ 100,00$ (cem reais); 2) 200 unidades a $\mathrm{R} \$$ 150,00 (cento e cinqüienta reais). O primeiro lote terá custo total de $\mathrm{R} \$ 10.000,00$ (dez mil reais) (produto de 100 unidades x $\mathrm{R} \$ 100,00$ ). O segundo lote terá custo total de $\mathrm{R} \$ 30.000,00$ (trinta mil reais) (produto de 200 unidades x R $\$ 150,00$ ). Teremos, portanto, 300 unidades a um custo total somado de $\mathrm{R} \$ 40.000,00$ (quarenta mil reais). Assim, o custo médio ponderado do estoque será de $\mathrm{R} \$ 133,34$ (cento e trinta e três reais e trinta e quatro centavos), pela razão entre $\mathrm{R} \$ 40.000,00$ divido por 300 unidades.
} 


\subsection{O ativo}

Por ativo podemos definir o conjunto de bens, créditos e outros direitos titularizados pela sociedade.

Para manter sua atividade, a sociedade necessita de um conjunto de bens, com maior ou menor liquidez. O ativo também mostra em que os capitais ou os financiamentos (próprios ou oriundos de terceiros) foram aplicados ou investidos.

Como explicitam Neves e Viceconti, os investimentos representados pelo ativo compreendem ${ }^{43}$ :

- Bens Numerários: são os bens de liquidez imediata, constituindo o disponível da empresa: dinheiro em espécie, depósitos bancários e aplicações financeiras de liquidez imediata (Fundo de Investimento Financeiro, por exemplo);

- Bens de Venda: são aqueles destinados à venda pela sociedade e que constituem o objeto de seu negócio. No caso de empresas industriais, são constituídos pelos estoques de produtos em elaboração e pelo de produtos acabados. Segundo Hilário Franco, alguns autores consideram os estoques de matérias-primas (ou de material direto ou indireto) como bens de venda pois, embora sua finalidade não seja a de serem vendidos, integram direta ou indiretamente o produto a ser vendido. Outros autores preferem classificá-los como bens circulantes, por não serem fixos (renovam-se constantemente);

- Bens Fixos: são aqueles bens de caráter permanente ou quase permanente e que constituem os meios de produção da empresa, servindo a vários ciclos produtivos. Também são conhecidos como bens de uso. Estão nesse grupo: Imóveis destinados às instalações do estabelecimento industrial (terrenos e edifícios). Máquinas e

\footnotetext{
${ }^{43}$ NEVES, Silvério das; VICECONTI, Paulo Eduardo Vilchez. Contabilidade de custos: um enfoque direto e objetivo. São Paulo: Frase, 2000. p. 1.
} 
Equipamentos; Instalações, ferramentas e aparelhos. Veículos, Móveis e Utensílios. São geralmente classificados no Ativo Imobilizado;

- Bens de Renda: são aqueles adquiridos com a finalidade de produzir renda para a sociedade e que não estão diretamente ligados a sua atividade. Exemplos: participações societárias de caráter permanente ou temporário, aplicações financeiras de liquidez não imediata, tais como CDBs, fundos de renda fixa, ouro, debêntures, etc., imóveis para alugar;

- Créditos de Funcionamento: valores a receber decorrentes da própria atividade da empresa. Exemplo: contas a receber, duplicatas a receber, etc.;

- Créditos de Financiamento: valores a receber de prazo mais longo decorrentes de financiamentos a terceiros e que não são relacionados com o objeto da atividade da empresa. Exemplo: Empréstimos Compulsórios à União;

- Valores Imateriais: bens não tangíveis que figuram no ativo, tais como marcas e patentes, despesas pré-operacionais, gastos com reorganização administrativa, etc.

Costuma-se classificar os componentes do ativo em ordem decrescente de liquidez. Esse aliás é o critério de classificação proposto pela Lei n. 6.404/76 no art. 17944, com redação da Lei $11.638 / 07^{45}$.

\footnotetext{
${ }^{44}$ Art. 179. As contas serão classificadas do seguinte modo: I - no ativo circulante: as disponibilidades, os direitos realizáveis no curso do exercício social subseqüente e as aplicações de recursos em despesas do exercício seguinte; II - no ativo realizável a longo prazo: os direitos realizáveis após o término do exercício seguinte, assim como os derivados de vendas, adiantamentos ou empréstimos a sociedades coligadas ou controladas (artigo 243), diretores, acionistas ou participantes no lucro da companhia, que não constituírem negócios usuais na exploração do objeto da companhia; III - em investimentos: as participações permanentes em outras sociedades e os direitos de qualquer natureza não classificáveis no ativo circulante, e que não se destinem à manutenção da atividade da companhia ou da empresa; IV - no ativo imobilizado: os direitos que tenham por objeto bens corpóreos destinados à manutenção das atividades da companhia ou da empresa ou exercidos com essa finalidade, inclusive os decorrentes de operações que transfiram à companhia os benefícios, riscos e controle desses bens; $V$ - no diferido: as despesas pré-operacionais e os gastos de reestruturação que contribuirão, efetivamente, para o aumento do resultado de mais de um
} 
Analisaremos cada qual dos componentes do ativo nos tópicos seguintes.

\subsubsection{O ativo circulante}

Denominam-se circulante os componentes do ativo de uma empresa que servem prioritariamente a seu giro comercial.

Com efeito, a empresa possui ordinariamente um ciclo de operações que inclui: 1) aquisição de mercadorias, matéria-prima ou insumos de fornecedores (seja para revenda, transformação ou utilização na prestação de serviços); 2) venda das mercadorias ou prestação de serviços, 3) transformação da mercadoria em dinheiro (caixa) ou valores a receber (clientes); 4) pagamento aos fornecedores com nova aquisição de mercadorias, insumos ou matérias-primas.

Graficamente, podemos estabelecer o seguinte:

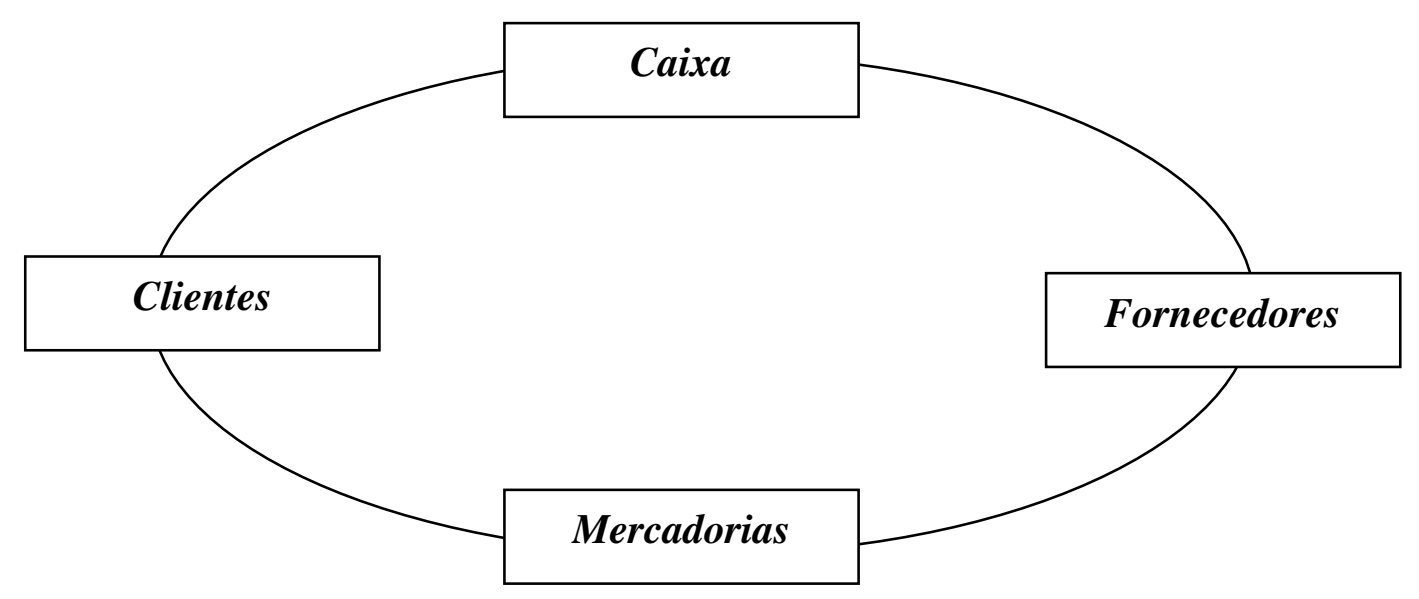

exercício social e que não configurem tão-somente uma redução de custos ou acréscimo na eficiência operacional; VI - no intangível: os direitos que tenham por objeto bens incorpóreos destinados à manutenção da companhia ou exercidos com essa finalidade, inclusive o fundo de comércio adquirido. Parágrafo único. Na companhia em que o ciclo operacional da empresa tiver duração maior que o exercício social, a classificação no circulante ou longo prazo terá por base o prazo desse ciclo.

${ }^{45}$ A redação da Lei n. 11.638/07 acompanhou o que já preconizava a deliberação da CVM n. 488, de 3 de outubro de 2005, que classificava o ativo tão-somente em circulante e não circulante, sendo que este último deveria ser desdobrado em ativo realizável a longo prazo, investimentos, ativo imobilizado, ativo intangível e ativo diferido. A mesma classificação é dada para o passivo. 
De qualquer ponto do ciclo, poderemos obter seu fechamento, mesmo nas vendas a prazo. Assim, se partirmos de mercadorias, observaremos que estas são vendidas, sendo transformadas em contas a receber dos clientes. Quando estes pagam seus valores, a entrada de dinheiro do caixa servirá para pagamento dos fornecedores e aquisição de novas mercadorias.

Os ativos utilizados nesse ciclo operacional são classificados no ativo circulante. Sua composição, dadas suas características, inclui aqueles ativos de liquidez imediata (dinheiro em caixa, aplicações financeiras de liquidez imediata, etc.), além das contas referentes aos estoques de mercadorias ou insumos, as contas a receber de clientes (usualmente denominadas “clientes" ou "duplicatas a receber") ${ }^{46}$.

De acordo com o critério adotado na Lei das Sociedades Anônimas, o ativo circulante compreenderá os direitos realizáveis no curso do exercício social subseqüente e as aplicações de recursos em despesas do exercício seguinte. Em suma: todos os ativos vencíveis até o final do exercício no qual se encerra o balanço patrimonial.

A conta usualmente denominada de caixa ${ }^{47}$ inclui as quantias em dinheiro e os cheques recebidos e ainda não depositados ou aplicados. Em conjunto com as aplicações financeiras de liquidez imediata (p. ex.: aplicações financeiras de poucos dias), a conta representa o que conjuntamente costuma-se chamar de "disponibilidades" ou "disponível" da empresa.

As aplicações financeiras de liquidez imediata, por sua vez, podem ser separadas em contas distintas, conforme se destinem ao movimento de valores, pagamentos específicos, cobrança, etc. Caso possuam saldo negativo, deverão ser classificadas no passivo circulante e não mais no ativo, pois representarão, ao invés de créditos, dívidas da empresa com instituições financeiras.

\footnotetext{
${ }^{46}$ Note-se que as contas relativas ao que a empresa deve aos fornecedores pelas atividades inerentes a seu ciclo operacional não são incluídas no ativo, pois se trata de dívidas. As contas de fornecedores estarão classificadas usualmente no passivo circulante, do qual teremos oportunidade de tratar no decorrer do texto.

${ }^{47}$ Não há denominação contábil obrigatória para as contas. Normalmente utiliza-se um padrão usualmente aceito pelos profissionais, que possa resumir o conteúdo da conta respectiva. No entanto, nada obsta que a conta "caixa" seja denominada "dinheiro em caixa", "quantias em dinheiro em poder da sociedade", etc. No texto, utilizaremos as denominações mais comuns da doutrina contábil.
} 
Os ganhos obtidos nas aplicações financeiras, consistentes em juros pagos por estas, devem ser classificados em contrapartida de conta de resultado da empresa (p. ex.: receitas de aplicações financeiras), influindo conseqüentemente em seu lucro líquido.

Para os valores de caixa e aplicações financeiras não existe qualquer discussão quanto ao valor a ser escriturado (a exemplo do que existe com os estoques), pois, tendo expressão monetária imediata, o montante escriturado será correspondente ao valor em moeda ou àquele que constar dos extratos bancários respectivos.

No entanto, quando a empresa tem suas aplicações financeiras vinculadas a títulos e valores mobiliários, a situação já se torna um pouco mais complexa. Nesses casos, o art. 183, I, da Lei n. 6.404/76, estipulava a adoção do princípio contábil: custo ou mercado, dos dois o menor, decorrência imediata do princípio contábil do conservadorismo ou do custo histórico como valor original, que determina a adoção do menor valor para a avaliação do ativo (ordinariamente o valor de custo, salvo se o valor de mercado for inferior).

Assim, se exemplificativamente uma companhia tivesse investido parte de seu ativo em um fundo de ações, deverá apresentar em sua escrituração o valor de custo de referido investimento, salvo se o valor de venda no mercado fosse inferior a este ${ }^{48}$.

Caso o valor de mercado fosse inferior ao de custo, não se recomenda uma diminuição na conta de investimento respectiva anteriormente escriturada. Faz-se ordinariamente uma provisão através de uma conta redutora ou retificadora de ativo, com a conseqüiente contrapartida nas contas de resultado.

A situação foi parcialmente modificada com o advento da Lei n. 11.638/07, que seguiu os padrões internacionais de contabilidade IFRS.

\footnotetext{
${ }^{48}$ Obviamente, se a empresa vender seu investimento, apurar-se-á o resultado respectivo, transferindo o valor a crédito de conta de resultado e a débito de seu caixa (este aumenta a débito). Não haverá mais aí problemas de critérios de avaliação.
} 
Com efeito, para os títulos e instrumentos financeiros (que agora incluem expressamente derivativos, como opções, contratos futuros e a termo), esta legislação abandonou parcialmente o primado do custo histórico como valor de registro pela contabilidade, para adotar como prioritário o valor de mercado ou equivalente, permanecendo o custo histórico como base subsidiária.

Agora, teremos três hipóteses para registro dos títulos na escrituração em relação aos títulos, valores mobiliários e outros similares ${ }^{49}$ :

1) Títulos e instrumentos financeiros destinados à venda imediata: registrados pelo valor de mercado;

2) Títulos e instrumentos financeiros destinados à negociação visando benefícios de curto prazo: registrados pelo valor de mercado;

3) Títulos e instrumentos financeiros destinados à permanência em carteira, demais direitos e aplicações incluindo títulos de crédito: registrados pelo valor de custo, ajustado ao valor de realização, quando este for inferior.

Restam avaliados pelo valor de custo (ou de mercado se este for inferior) os estoques de matérias-primas, produtos em elaboração ou mercadorias (art. 183, II) ${ }^{50}$.

Classificam-se também no ativo circulante as contas a receber ("clientes", “duplicatas a receber" e congêneres).

Aqui uma ressalva é necessária, dado que o art. 179, II, determina que se classifiquem no ativo realizável a longo prazo (e não no circulante) os direitos derivados de vendas, adiantamentos ou empréstimos a sociedades coligadas ou controladas (artigo 243),

\footnotetext{
49 Segundo as normas internacionais de contabilidade (IFRS), haverá diferença na contrapartida dos lançamentos contábeis referentes ao ajuste de valor de mercado para os títulos destinados à negociação e à venda. Enquanto os primeiros terão sua contrapartida no resultado, os segundos terão contrapartida em conta de reservas no patrimônio líquido.

${ }^{50}$ Em relação aos bens e direitos do imobilizado e intangível também foi adotado o mesmo critério de custo no art. 183, V e VII, ressalvando-se, aqui, a dedução das despesas de depreciação, exaustão ou amortização.
} 
diretores, acionistas ou participantes no lucro da companhia, que não constituírem negócios usuais na exploração do objeto da companhia.

Assim, se uma empresa titularizar ações de outra como coligada ou controlada e, sem que se constitua operação habitual entre ambas, efetuar venda com pagamento a prazo a esta, deverá classificá-la no exigível a longo prazo, mesmo que tal obrigação se vença no curso do exercício seguinte. A razão disso é que, em se tratando de operação entre coligadas e controladas, entende o legislador que o titular do crédito poderá não ter o mesmo empenho ou celeridade em cobrá-lo, que teria se o devedor fosse um terceiro.

Ressalvada tal hipótese, as contas a receber, vencíveis até o final do exercício seguinte, são classificadas no ativo circulante.

Há, entretanto, alguns problemas que devem ser analisados.

Verifica-se na prática que nem sempre as sociedades costumam receber os valores totais de seus créditos. Com efeito, existe sempre no mercado algum percentual de clientes inadimplentes, pelas mais diversas causas.

A escrituração, por óbvio, não pode ignorar tal fenômeno, devendo representá-lo em seus lançamentos e demonstrações, sob pena de mostrar aos seus destinatários um volume de ativos que efetivamente não serão recebidos.

Assim, costuma-se fazer um lançamento apropriado, ordinariamente denominado provisão para créditos de liquidação duvidosa (PCLD) ou provisão para devedores duvidosos (PDD) $)^{51}$.

Tal lançamento é feito através da constituição de uma conta retificadora do ativo respectivo, com uma contrapartida em conta de resultado.

\footnotetext{
51 As normas de contabilidade internacionais (IFRS) estabelecem a constituição de provisões quando determinado evento seja simultaneamente provável e seu montante seja determinável, com razoável grau de segurança. Os passivos contingentes, que não tenham tais requisitos, poderão ser informados em notas explicativas.
} 
Exemplificativamente, suponhamos que uma sociedade tenha um valor de $\mathrm{R} \$ 100.000,00$ (cem mil reais) em sua conta "clientes" ou "duplicatas a receber". Ocorre que, usualmente, a empresa sabe que $10 \%$ desses valores não são ordinariamente recebidos.

Diante do fato, deverá lançar $\mathrm{R} \$ 10.000,00$ (dez mil reais) na conta de provisão para devedores duvidosos (conta retificadora das contas "clientes" ou "duplicatas a receber"), além do mesmo valor em conta de resultado (p. ex.: "despesas com devedores duvidosos").

Assim, estará reduzindo seu ativo e seu resultado operacional em R\$ 10.000,00 (dez mil reais), evidenciando a realidade provável ao destinatário de suas demonstrações.

Tratando-se de valores meramente prováveis de inadimplência, contudo, poderá esta não vir a se realizar no futuro. Pode ocorrer, por exemplo, que a parcela de devedores inadimplentes seja igual, inferior ou superior a $\mathrm{R} \$ 10.000,00$ (dez mil reais).

No caso de ser igual (a provisão feita anteriormente corresponde exatamente à inadimplência ocorrida), deverá ser a conta retificadora de provisão encerrada contra aquela representativa dos valores a receber dos clientes.

Se não utilizada a totalidade da provisão (por ser superior à inadimplência prevista), a diferença deverá ser revertida, creditando-se uma conta de resultado (p. ex.: “reversão de PDD”) e debitando-se a conta retificadora de provisão no valor respectivo.

$\mathrm{Na}$ hipótese de a provisão ser insuficiente (inferior à inadimplência prevista), a partir do momento em que a inadimplência superar os valores provisionados, deverão estes ser lançados no resultado como despesas (p. ex.: em conta denominada "Perdas com clientes").

Muitas vezes são realizadas algumas operações financeiras para possibilitar a existência de dinheiro em caixa, através do recebimento antecipado junto a instituições financeiras de suas contas a receber. A operação mais comum é o desconto de duplicatas. 
No desconto de duplicata, normalmente é cobrada pela instituição financeira uma série de valores, que incluem juros ou descontos antecipados, despesas diversas (verificação do crédito, etc.), o que acarreta uma redução do valor recebido pela sociedade credora do título e o valor nominal deste constante.

No caso de desconto, deverá fazer a seguinte operação: 1) o valor efetivamente pago pela instituição deve ser debitado na conta caixa ou aplicações (débito); 2) os juros ou descontos antecipados serão debitados em conta de ativo, sendo transferidos para o resultado conforme o passar do tempo; 3) as despesas cobradas serão debitadas em conta de resultado (p. ex.: despesas financeiras); 4) o valor da duplicata descontada, correspondente à soma das parcelas descritas em 1, 2 e 3 será creditado em conta retificadora de ativo.

Como normalmente a instituição financeira recebe o título mediante endosso translativo, não devemos esquecer da possibilidade de, no vencimento, o devedor principal não honrar o pagamento da duplicata, ficando o endossante responsável por tanto. Assim, teremos duas possibilidades: 1) no vencimento há o pagamento por parte do devedor principal: o valor da conta retificadora "duplicatas descontadas" deverá ser debitado, contra o crédito da conta de ativo "duplicatas a receber", extinguindo-se a primeira com redução (ou até extinção) da segunda; 2) no vencimento não há o pagamento por parte do devedor principal, cobrando-se do endossante: nessa hipótese, deve-se creditar a conta caixa ou aplicações financeiras (aquela de onde saírem os recursos para pagamento) contra o débito de "duplicatas descontadas" (que é extinta); a conta "duplicatas a receber" deve ser mantida, pois com o pagamento do título poderá o endossante agir regressivamente contra o devedor principal, mantendo seu crédito.

É comum ainda a manutenção no ativo circulante de contas referentes a tributos recuperáveis, como imposto sobre circulação de mercadorias e serviços (ICMS), sobre produtos industrializados (IPI), além das contribuições do PIS e COFINS, quando não cumulativas.

Efetivamente, tais tributos não fazem parte do custo da mercadoria ou serviço adquiridos quando a sociedade anônima for contribuinte específico dessas exações. 
Caso não o seja, deverão os valores de tributos ser incluídos no custo das mercadorias vendidas ou dos serviços prestados.

Para a escrituração, teremos o seguinte: os valores de ICMS, IPI, etc. não cumulativos deverão ser separados do preço cobrado pela mercadoria e contabilizados a débito de conta de ativo ("ICMS ou IPI a recuperar", por exemplo). Quando da venda de mercadorias ou prestação de serviços, serão creditados os valores dos tributos mencionados em contas de resultado (“despesas de ICMS ou IPI"), com a contrapartida de um passivo (obrigação a pagar, p. ex.: "ICMS ou IPI a pagar”).

Quando do pagamento dos impostos, deve-se confrontar a conta de ativo com a conta de passivo supracitadas, jogando os valores de uma contra a outra. Se o valor da conta de ativo for maior, não há imposto a pagar, mantendo-se um valor (diferença) no ativo (crédito de tributos). Caso o valor do passivo seja maior, a diferença entre as contas será o valor a pagar ao fisco.

Outro aspecto importantíssimo que aparece no ativo circulante são as contas de estoques. Aqui há um grande objeto de estudo, havendo um imenso material a ser discutido, que não pretendemos esgotar no presente trabalho.

Já vimos anteriormente os critérios utilizados comumente para a baixa de estoques (preço específico, PEPS, UEPS, média ponderada). Esta, no entanto, é apenas uma das faces do problema.

Os estoques variam conforme o ramo da empresa.

De fato, se a sociedade atuar no ramo comercial, os custos de suas mercadorias em estoque serão aqueles decorrentes do preço de aquisição, somados aos demais custos para a colocação do bem à venda (fretes, seguros, etc.).

Caso se dedique a prestação de serviços, quase sempre com a utilização de algum material ou insumo em sua atividade, o mesmo princípio é válido, acrescentando que os estoques, aqui, costumam ser menores. 
No entanto, caso a sociedade se destine à exploração do ramo industrial, os problemas para determinar o valor dos estoques são mais complexos, uma vez que é necessário computar aqui os custos de transformação, que envolvem diversos aspectos, custos fixos, variáveis, entre outros ${ }^{52}$. A contabilidade de custos estabelece alguns critérios para o custeio dos estoques:

- Custeio por absorção: são separados os custos (gastos inerentes à produção dos bens destinados à venda) das despesas (gastos não inerentes à produção dos bens destinados à venda). Os custos (fixos e variáveis) são inseridos no preço dos estoques de produtos acabados enquanto as despesas são inseridas no resultado;

- Custeio variável: só os custos variáveis (os que variam com o volume da produção) são considerados custos dos estoques de produtos acabados. Os custos fixos e as despesas são inseridos no resultado;

- Custeio ABC ou custeio baseado em atividades (activity based cost): são mapeadas as atividades da empresa na produção dos bens de venda e os recursos que elas consomem. Após, são rateados os custos para os produtos individualmente.

Há outros critérios, que não pretendemos abordar aqui (RKW, departamentalização, etc.), ficando consignado a maior dificuldade das sociedades industriais em determinar o custo de estoque, e até mesmo a medida exata de seu lucro, pois sempre haverá algum grau de arbitrariedade, conforme o critério usado.

Normalmente, para fins de escrituração, utiliza-se o sistema de custeio por absorção, sendo usualmente obrigatório pela legislação fiscal. Para fins gerenciais internos, entretanto, poderão ser utilizados outros sistemas.

\footnotetext{
${ }^{52}$ Conceitualmente, a contabilidade divide os custos fixos e variáveis, sendo os primeiros aqueles que não variam conforme o volume de produção e os últimos os que variam. Exemplo de custos fixos seriam o aluguel do imóvel da fábrica em que a sociedade se situa (a variação da produção não altera seus valores). Exemplo de custo variável seria a matéria-prima utilizada na fabricação (quanto mais se produzir, maior o custo de matéria-prima).
} 
Há alguns tipos de bens que não comportam o mesmo tratamento dos estoques. Como ressaltam Iudícibus et al.: "O estoque, em sua forma tradicional (por exemplo, mercadoria), quando comercializado, gera receita que é confrontada com a baixa integral do custo desse estoque vendido, pois ocorre a transferência integral de propriedade e controle. Além disso, essa baixa integral (em bases unitárias, quilos, metros, etc.) também decorre de consumo ou transformação em produtos"

Nessa espécie de bens, chamados pelos autores supracitados de ativos especiais, entram aqueles tipos que não se esgotam com a alienação da propriedade (p. ex.: atividades de aluguel de filmes, transferência de marcas, comercialização de dados, etc.). Para tais ativos deve-se prever simplesmente sua amortização conforme critérios próprios e específicos para cada bem e não baixa de estoque pela venda. Veremos com mais vagar a amortização no decorrer do texto.

Também é comum no ativo circulante a existência de contas referentes a créditos da sociedade empresarial por créditos a receber oriundos de atividades não operacionais. Exemplo ocorre na venda de ativo imobilizado a prazo, na qual será dada baixa no ativo imobilizado respectivo (crédito em conta de ativo imobilizado) em contrapartida do aumento (a débito) no ativo circulante (p. ex.: em “contas a receber").

Por fim, poderão fazer parte do ativo circulante as aplicações de recursos em despesas do exercício seguinte, também denominadas despesas antecipadas, adiantamentos a clientes ou despesas pagas antecipadamente, expressamente referidas no art. 179, I, da Lei n. 6.404/76.

Suponhamos um caso concreto em que a sociedade venha a contratar um seguro de automóvel em junho de 2006, pelo prazo de um ano, adiantando à seguradora todo o pagamento do período.

$\mathrm{Na}$ verdade, nesta hipótese a empresa adquiriu um direito de usufruir o seguro contratado pelo pagamento antecipado. Por outro lado, não seria próprio reconhecer

\footnotetext{
${ }^{53}$ IUDÍCIBUS, Sérgio de; MARTINS, Eliseu; GELBCKE, Ernesto Rubens. Op. cit., p. 135.
} 
no resultado uma despesa pelo pagamento, uma vez que não houve a contrapartida de receita (a empresa não usou totalmente o direito consistente no seguro contratado) ${ }^{54}$. Devese, assim, manter o valor retirado das disponibilidades da empresa (caixa, aplicações, etc.) em conta de ativo (p. ex.: "despesas antecipadas"), para que, com o passar do tempo e conseqüente utilização do objeto do contrato de seguro, sejam as despesas paulatinamente transferidas para o resultado.

\subsubsection{O ativo realizável a longo prazo}

Não há diferença ontológica entre o ativo circulante e o ativo realizável a longo prazo. A mesma estrutura de contas existente no primeiro, portanto, poderá aparecer no segundo. A distinção entre essas categorias se faz apenas em relação ao prazo de realização do bem ou direito respectivo.

Poderão compor o ativo realizável a longo prazo aplicações financeiras com resgate a longo prazo ou vinculadas a pagamentos de empréstimos de longo prazo.

Igualmente, contas a receber no longo prazo, incluindo suas provisões para devedores duvidosos, podem constar neste tópico.

Consideram-se de longo prazo, para efeito da classificação neste item, os direitos realizáveis após o término do exercício seguinte ao encerramento daquele em que se conclui o balanço patrimonial do exercício correspondente.

Reiteramos aqui a ressalva feita pela Lei n. 6.404/76, já referida anteriormente, segundo a qual também serão classificados no ativo realizável a longo prazo

\footnotetext{
${ }^{54}$ Explica-se aqui o princípio da confrontação entre receita e despesa, segundo o qual uma despesa somente pode ser reconhecida como tal quando confrontada, no mesmo período, com a receita a ela inerente. Note-se que receita e despesa, dada a aplicação do princípio da competência, não se identificam com a entrada e saída de dinheiro do caixa, mas com o uso e consumo de bens (despesa) e com a transferência de bens ou prestação de serviços a terceiros (receita).
} 
os direitos derivados de vendas, adiantamentos ou empréstimos a sociedades coligadas ou controladas (artigo 243), diretores, acionistas ou participantes no lucro da companhia, que não constituírem negócios usuais na exploração do objeto da companhia.

Neste último caso, a classificação independe do prazo. Como bem ensina Modesto Carvalhosa: "Para a classificação de créditos dessa espécie, é irrelevante o prazo de realização. Assim, uma companhia com objetivos industriais ou comerciais, que conceder um empréstimo ou adiantamento a diretor, acionista, sociedades coligadas ou controladas, considerará o empréstimo no realizável a longo prazo, ainda que o termo contratual do empréstimo seja fixado, por exemplo, para o sexto mês subseqüente à data do balanço" ${ }^{\text {5 }}$.

Nos termos da nova redação dada ao art. 183, VIII, da Lei n. 6.404/76, pela Lei n. 11.638/07, os elementos do ativo decorrentes de operações de longo prazo serão ajustados a valor presente, sendo os demais ajustados quando houver efeito relevante.

\subsubsection{O ativo permanente}

O ativo permanente compõe-se daqueles bens e direitos não destinados à venda imediata, que a empresa insere como meios para realização de sua atividade.

A característica de permanência do ativo é sempre de natureza relativa. Primeiramente, salvo algumas exceções, os ativos permanentes sofrem desgaste e/ou obsolescência pelo uso. Ao depois, a destinação de um determinado ativo pode ser modificada com o tempo: ilustre-se com o exemplo de uma empresa de informática, atuando no ramo de venda de computadores, que vem a destinar um destes, anteriormente usado para processamento de dados internos, à venda para seus clientes. Passa-se um

\footnotetext{
${ }^{55}$ CARVAlHOSA, Modesto; LATORRACA, Nilton. Comentários à lei de sociedades anônimas. São Paulo: Saraiva, 1998. v. 3, p. 589.
} 
mesmo bem, antes classificado no ativo permanente (imobilizado), para o ativo circulante (estoque).

Subdivide-se o ativo permanente em quatro classes:

a) Investimentos: compreendem genericamente os investimentos permanentes da sociedade em outras sociedades;

b) Imobilizado: compreende os direitos que tenham por objeto bens corpóreos destinados à manutenção das atividades da companhia ou da empresa ou exercidos com essa finalidade, inclusive os decorrentes de operações que transfiram à companhia os benefícios, riscos e controle desses bens ${ }^{56}$;

c) Intangível: compreende os direitos que tenham por objeto bens incorpóreos destinados à manutenção da companhia ou exercidos com essa finalidade, inclusive o fundo de comércio adquirido;

d) Diferido: compreende os gastos que contribuirão para a formação do resultado de mais de um exercício social (por exemplo: gastos na fase pré-operacional, gastos com pesquisa e desenvolvimento etc.).

Analisaremos com mais pormenores cada um dos itens citados nos tópicos seguintes.

\footnotetext{
56 Importante salientar que este item não é restrito aos bens imóveis, como pode fazer sugerir a nomenclatura. Compreende bens móveis (máquinas, equipamentos, veículos etc.), além de marcas, patentes etc. A mudança de redação dada pela Lei n. 11.638/07 veio abranger aqui o registro do bem objeto de leasing financeiro (operação que consubstancia na prática verdadeiro financiamento) como ativo imobilizado. Tratase, na verdade, de uma contabilização correspondente a uma verdadeira aquisição a prazo.
} 


\subsubsection{Os investimentos}

De acordo com o art. 179, II, da Lei n. 6.404/76, devem ser classificados em investimentos as participações permanentes em outras sociedades e os direitos de qualquer natureza, não classificáveis no ativo circulante, e que não se destinem à manutenção da atividade da companhia ou da empresa.

Dessa forma, precisaremos separar inicialmente três situações distintas quanto às participações societárias: 1) a sociedade que possui ações de outra(s) destinada(s) à venda imediata ou com possibilidade real ou pretensão de alienação (p. ex.: investimento em bolsa de valores com prazo diário - day trade - ou mensal); 2) investimento destinado à venda ou com pretensão de venda após o exercício seguinte ao fechamento do balanço do exercício corrente; 3) investimento em outras sociedades, sendo que a participação não se destina à venda, tendo finalidade de permanência na empresa.

No primeiro caso, o ativo será classificado no circulante. No segundo caso, teremos um ativo classificado no realizável a longo $\operatorname{prazo}^{57}$. No terceiro, no permanente, subgrupo investimentos.

Além das participações societárias, outros direitos de qualquer natureza podem ser classificados no subgrupo investimentos. Um imóvel, v.g., não destinado à venda, nem utilizado nas atividades, mas mantido para futura expansão, deve ter a rubrica de investimento. Veremos com mais detalhes esse aspecto quando do exame do ativo imobilizado.

Cumpre aqui analisar os tipos de investimento possível em participações societárias e sua repercussão na escrituração empresarial.

\footnotetext{
57 Iudícibus et al. alertam para o pequeno lapso da lei ao não definir no art. 179 a possibilidade de investimentos classificáveis no ativo de longo prazo: "Houve aqui um pequeno lapso da lei, que precisaria ter adicionado 'e não classificáveis também no Realizável a Longo Prazo', pois, dando ao texto interpretação literal, concluiríamos não existir esse realizável a longo prazo, porquanto o que não estivesse no circulante estaria no permanente. Devemos por isso interpretar o texto com a inclusão dessa expressão adicional” (IUDÍCIBUS, Sérgio de; MARTINS, Eliseu; GELBCKE, Ernesto Rubens. Op. cit., 2003).
} 
Basicamente, existem dois métodos possíveis para a escrituração das participações societárias:

\section{1) O método de custo;}

\section{2) O método da equivalência patrimonial (MEP).}

De acordo com o método de custo, a participação permanente em outra sociedade (investimento) será consignada na escrituração da investidora pelo custo de aquisição, corrigido pela provisão para adequação dos valores escriturados.

Ainda que o valor do patrimônio líquido da sociedade investida se altere (p. ex.: com o aumento da conta de lucros acumulados), manter-se-á a escrituração original pelo custo de aquisição.

Já pelo método da equivalência patrimonial, a escrituração na investidora deve refletir, a cada exercício, o valor correspondente de participação patrimonial na investida, através da aplicação do percentual correspondente. Dessa forma, se a investida aumentar seu patrimônio líquido, a escrituração na investidora deverá acompanhar tal aumento, consignando suas posições exatas.

Resta claro que o método de equivalência patrimonial é mais trabalhoso: é necessário a cada exercício que a investidora conheça previamente o balanço patrimonial de sua investida para que possa escriturar o valor de seu investimento, necessidade que não se faz presente na utilização do método de custo.

Quando será utilizado um método ou outro?

Respondem à pergunta os arts. 183, III, e 248 da Lei n. 6.404/1976, ressalvando-se o método de equivalência patrimonial para os casos de controladas, ou em 
coligadas nos quais haja influência significativa na administração ${ }^{58}$, e o método de custo para os demais casos.

Vale dizer que ao método de custo foi relegado um papel residual; ou seja, caberá seu emprego quando não forem aplicáveis as normas que determinam o emprego do método de equivalência patrimonial. A este último método, dada a maior dificuldade de processamento e obtenção dos dados, foi reservado o campo dos investimentos de maior porte.

Um resumo dos casos aplicáveis é feito no quadro seguinte.

\section{Quadro 5: aplicação dos métodos de custo e equivalência patrimonial}

\begin{tabular}{|l|l|}
\hline $\begin{array}{l}\text { Normas que } \\
\text { regulamentam o } \\
\text { emprego dos métodos de } \\
\text { escrituração }\end{array}$ & $\begin{array}{l}\text { Lei n. 6.404/1976, com redação da Lei n. 11.638/07 } \\
\text { e Instrução 247/1996 da CVM. }\end{array}$ \\
\hline Controladas & $\begin{array}{l}\text { Método de equivalência patrimonial (MEP) para } \\
\text { todas. }\end{array}$ \\
\hline Coligadas & $\begin{array}{l}\text { MEP se houver influência significativa, } \\
\text { participação superior a 20\% do capital votante, ou } \\
\text { fizer parte de um mesmo grupo societário ou estiver } \\
\text { sob controle comum. }\end{array}$ \\
\hline Outros investimentos & $\begin{array}{l}\text { Método de custo, salvo se fizer parte de um mesmo } \\
\text { grupo societário ou estiver sob controle comum. }\end{array}$ \\
\hline
\end{tabular}

Hipótese interessante é a ocorrência de distribuição de dividendos por uma sociedade sobre a qual recai um investimento de outra.

Caso a escrituração da sociedade investidora seja feita pelo método de custo, a entrada de dinheiro no caixa deve ser feita através de débito em conta de ativo ("caixa", "aplicações" etc.) em contrapartida de crédito em resultado (p. ex.: "Receita de

\footnotetext{
58 Anteriormente ao advento da Lei n. 11.638/07, o critério para uso de um dos métodos baseava-se na relevância do investimento (art. 247, parágrafo único). Com a modificação do art. 248 (embora sem revogar o art. 247), não se faz mais referência à relevância, mas meramente à influência significativa na administração (presumida pela participação superior a $20 \%$ no capital votante), participação em grupo societário ou controle comum. Muito embora o critério atual esteja de acordo com as normas contábeis internacionais, o método anterior parecia mais objetivo. Com efeito, será difícil, por vezes, determinar se a "influência significativa" na administração de uma coligada realmente existe na prática. Uma solução pode ser efetivamente interpretar a expressão "influência significativa" como a relevância objetivamente considerada no art. 247, parágrafo único da Lei n. 6.404/76.
} 
dividendos"). Procedimento similar deve ocorrer quando os dividendos já foram aprovados pela Assembléia da investida, devendo-se debitar conta de ativo (p. ex.: "dividendos a receber") em contrapartida também de uma conta de resultado.

Mas, se a escrituração for feita através do método de equivalência patrimonial, devemos nos atentar ao fato de que a distribuição de dividendos reduz o patrimônio líquido da sociedade investida. Assim, o dinheiro que entra em caixa também diminuirá a base de cálculo sobre a qual o percentual de participação da investidora incide.

Duas hipóteses merecem ainda nossa análise: 1) a existência de lucros não realizados entre controladas e coligadas e a sociedade investidora; 2) a existência de coligadas ou controladas com patrimônio líquido negativo.

A primeira hipótese é a contida no art. 248, I, da Lei n. 6.404/76, quando em sua parte final preceitua que no valor de patrimônio líquido não serão computados os resultados não realizados decorrentes de negócios com a companhia, ou com outras sociedades coligadas à companhia, ou por ela controladas.

Mais uma vez irrepreensível a lição de Iudícibus et al.: "O objetivo da eliminação dos lucros não realizados do patrimônio líquido da coligada ou controlada deriva do fato de que, realmente, somente se deve reconhecer lucro em operações com terceiros, pois as vendas de bens de uma para outra empresa do mesmo grupo não geram economicamente lucro, em termos de todo o grupo, a não ser quando tais bens foram vendidos para terceiros" $" 59$.

Diante disso, somente quando a investidora alienar ou baixar o bem adquirido é que o lucro obtido na alienação será computado no patrimônio líquido. Visualiza-se, portanto, o grupo formado por investidora e suas controladas e coligadas como um todo único, razão pela qual somente haverá o lucro quando a investidora efetivamente o realizar pela venda a terceiros ou outro tipo de baixa.

${ }^{59}$ IUDÍCIBUS, Sérgio de; MARTINS, Eliseu; GELBCKE, Ernesto Rubens. Op. cit., p. 172. 
Veja-se que para os demais acionistas das controladas e coligadas o lucro será real e efetivo, razão pela qual a CVM, contrariando (ou melhor, interpretando) a Lei n. 6.404/76, referiu-se a critério mais consentâneo com a realidade: os lucros não realizados não devem ser excluídos do patrimônio líquido das coligadas ou controladas, mas dele subtraídos somente para os efeitos de desconsiderar o lucro não realizado ${ }^{60}$.

Finalmente, se a controlada ou coligada tiver patrimônio líquido negativo. Em tal caso, recomenda-se normalmente que o investimento seja escriturado por valor zerado, ante a limitação de responsabilidade patrimonial da sociedade investidora (a investidora não perderá mais que o valor de seu investimento). Novas perdas não gerarão novas equivalências.

Casos haverá, entretanto, que a sociedade investidora poderá ter de arcar com prejuízos maiores que seus investimentos, como por exemplo nas hipóteses de desconsideração da personalidade jurídica de coligadas ou controladas, ou até mesmo por ter assumido tal circunstância contratualmente. Nesses casos será cabível a escrituração de valores negativos, através da constituição de uma provisão.

\subsubsection{O imobilizado}

Ao contrário do que o nome pode sugerir, o ativo imobilizado não compreende somente bens imóveis. De acordo com o art. 179 da Lei n. 6.404/76, ele abarca os direitos que tenham por objeto bens destinados à manutenção das atividades da companhia e da empresa, ou exercidos com essa finalidade, inclusive os de propriedade industrial ou comercial.

\footnotetext{
${ }^{60}$ Art. $9^{\circ}$ da Resolução 247/96 da CVM: O valor do investimento, pelo método da equivalência patrimonial, será obtido mediante o seguinte cálculo: I - aplicando-se a percentagem de participação no capital social sobre o valor do patrimônio líquido da coligada e da controlada; e II - subtraindo-se, do montante referido no inciso I, os lucros não realizados, conforme definido no parágrafo $1^{\circ}$ deste artigo, líquidos dos efeitos fiscais.
} 
Estão compreendidos aqui bens tangíveis, sendo que, após o advento da Lei n. 11.638/07, os intangíveis devem ter classificação própria no balanço patrimonial.

Como ressaltamos anteriormente, a classificação de um determinado bem no ativo imobilizado, no ativo circulante ou no realizável a longo prazo pode variar conforme o caso concreto. Um computador será classificado como estoque para uma empresa cuja atividade seja a venda de hardware. Este mesmo computador será classificado como imobilizado se estiver destinado ao uso interno dos advogados de um escritório jurídico para elaboração de peças processuais.

O valor do bem a ser escriturado compreenderá todos aqueles custos e/ou despesas necessários à sua colocação em efetivo e pronto uso. Assim, deverão ser computados os custos de aquisição referentes ao transporte (fretes, etc.), impostos não recuperáveis, despesas e emolumentos de cartórios, entre outros.

A escrituração de um determinado bem no imobilizado deve ser feita quando a companhia detém a propriedade e não somente a posse do bem. Dessa forma, um imóvel alugado não deve ser escriturado no imobilizado da sociedade locatária, devendo ser escriturados meramente os passivos referentes às dívidas locatícias, seu reconhecimento respectivo como despesa e as saídas de caixa para os pagamentos necessários.

Casos há, entretanto, que podem subverter esta regra.

Exemplo disso se deu quando o Conselho Federal de Contabilidade aprovou a Resolução 921/01, na qual estipula que no caso de arrendamento financeiro o bem arrendado deve ser incluído no ativo imobilizado da sociedade arrendatária, em contrapartida ao valor total das contraprestações e do valor residual, que deve ser registrado no passivo circulante ou no exigível a longo prazo.

Nessa mesma linha, a recente alteração da legislação do anonimato com o advento da Lei n. 11.638/07, que passou a incluir nessa classe de ativo aqueles decorrentes de operações que transfiram à companhia os benefícios, riscos e controle desses bens, sem 
que necessariamente haja a propriedade destes, incluindo claramente no imobilizado a hipótese do leasing financeiro.

Ressalvadas algumas exceções (p. ex.: os terrenos), o ativo imobilizado sofre ordinariamente de um desgaste ou perda de valor pelo uso ou pela obsolescência tecnológica.

A escrituração não pode restar alheia a tal fato, razão pela qual deve ser computada a perda de valor dos bens componentes do imobilizado.

Classifica-se a desvalorização do imobilizado pelo uso ou obsolescência em três tipos básicos:

- Depreciação: aplica-se aos bens tangíveis ou materiais;

- Amortização: aplica-se aos bens intangíveis ou imateriais;

- Exaustão: aplica-se aos bens cuja utilização ou extração de recursos implica seu esgotamento futuro (p. ex.: recursos minerais ou florestais).

Ontologicamente, entretanto, os três tipos acima citados são facetas de um mesmo fenômeno, qual seja o reconhecimento da vida útil limitada dos bens componentes do imobilizado.

A escrituração dos valores de depreciação, exaustão e amortização obedece aos mesmos critérios e é feita através do registro a crédito em uma conta retificadora (denominada usualmente “depreciação/amortização/exaustão acumulada”) em contrapartida à escrituração de uma despesa em conta de resultado (p. ex.: "despesas de depreciação/amortização/exaustão").

Vários são os critérios ou métodos para estabelecer os valores devidos a serem escriturados a título de depreciação. Entre eles, temos os seguintes: 
- Método linear ou das cotas constantes: no qual se estabelece o valor de custo de um determinado bem, diminuindo-se de seu valor residual (valor que resta após o uso integral do bem). Após, divide-se o resultado pelo intervalo de tempo de sua vida útil. É seguramente o método mais utilizado na prática ${ }^{61}$;

- Método das somas dos dígitos dos anos: somam-se os algarismos que compõem o número de anos correspondentes à vida útil de um bem, inserindo-os cada qual em uma fração com denominador igual a essa soma;

- Métodos de unidades produzidas ou horas trabalhadas: divide-se o número de unidades ou de horas produzidas ou trabalhadas pelo número total de unidades ou horas estimadas.

A venda de um ativo já depreciado/amortizado/exaurido, no todo ou em parte, deve observar alguns critérios.

Primeiramente deve-se apurar o valor contábil líquido do bem. Assim, se um imóvel tem um valor de custo de $\mathrm{R} \$ 100.000,00$, já depreciado em R $\$ 20.000,00$, seu valor contábil líquido será de $\mathrm{R} \$ 80.000,00$. Se o preço de venda for superior ou inferior a este último valor, a diferença deve ser computada no resultado como ganho/perda de capital ou lucro/prejuízo na venda de imobilizado.

${ }^{61}$ Façamos um exemplo prático: para um bem de valor $\mathrm{R} \$ 10.000,00$, com valor residual de $\mathrm{R} \$ 1.000,00 \mathrm{e}$ vida útil de 10 anos. $\mathrm{O}$ valor anual a ser contabilizado como depreciação é de $(10.000-1000) / 10=\mathrm{R} \$ 900,00$. 


\subsubsection{O diferido}

Diferir, de acordo com o Dicionário Aurélio ${ }^{62}$, significa adiar, procrastinar, retardar, demorar, delongar.

A Lei n. 6.404/76 descreve em seu art. 179, V, o ativo diferido, salientando que este compreende as aplicações de recursos em despesas que contribuirão para a formação do resultado de mais de um exercício social, inclusive os juros pagos ou creditados aos acionistas durante o período que anteceder o início das operações sociais.

Essa rubrica abrange prioritariamente os gastos incorridos na fase préoperacional da sociedade, ou seja, naquela fase em que se dá a constituição do empreendimento. Usualmente, têm-se gastos com construções de imóveis, compras de maquinário, pesquisas e desenvolvimento de produtos. Todos esses gastos irão ser compensados ou aproveitados futuramente e deles derivará toda ou boa parte da receita vindoura da sociedade que então se forma.

Ocorre que, por não estar em funcionamento, não há venda de bens ou prestação de serviços e, conseqüentemente, não há receita apropriável. A sociedade ainda não pode falar em lucros ou resultados.

Não havendo uma receita produzida ou a produzir, não se pode reconhecer a despesa com ela correlacionada no resultado empresarial. Assim fosse, teríamos um grande dispêndio de recursos iniciais e a ausência, futuramente, de despesas a serem confrontadas com as receitas futuras. Isso levaria a um grande descompasso entre despesas e receitas ao longo dos períodos pré-operacional e operacional ${ }^{63}$.

\footnotetext{
${ }^{62}$ Novo Dicionário Aurélio da Língua Portuguesa. Curitiba: Editora Positivo. 1 CD-ROM.

${ }^{63} \mathrm{Tem}$-se novamente aqui o princípio da confrontação entre receita e despesa, segundo o qual uma despesa somente pode ser reconhecida como tal quando confrontada, no mesmo período, com a receita a ela inerente. Note-se que receita e despesa, dada a aplicação do princípio da competência, não se identificam com a entrada e saída de dinheiro do caixa, mas com o uso e consumo de bens (despesa) e com a transferência de bens ou prestação de serviços a terceiros (receita).
} 
Diante disso, ao invés de se reconhecerem as despesas no resultado, mantêm-se estas no ativo (ativam-se as futuras despesas), para transferência paulatina e futura para as contas de resultado.

$\mathrm{O}$ ativo diferido, embora se assemelhe, não se confunde com as despesas antecipadas, a serem escrituradas no ativo circulante ou realizável a longo prazo. As despesas antecipadas não são despesas já incorridas, enquanto no diferido têm-se despesas já incorridas, mas ainda não reconhecidas como tal. Ademais, a apropriação ao diferido se faz por estimativa e não em bases concretas como nas despesas antecipadas.

A transferência dos valores escriturados no ativo diferido para o resultado se dá através do processo de amortização (em conta retificadora de ativo com contrapartida de despesa), de maneira muito similar ao que se verificou no estudo do imobilizado. Normalmente faz-se a amortização pelo período que se espera de benefício futuro.

\subsubsection{O intangível}

A Lei n. 11.638/07 inovou a sistemática originariamente adotada pela Lei n. 6.404/76, ao incluir na classificação do ativo aquela correspondente ao intangível.

Como salientamos anteriormente, essa classe inclui os direitos que tenham por objeto bens incorpóreos destinados à manutenção da companhia ou exercidos com essa finalidade (p. ex.: marcas, patentes, direitos autorais, etc.), inclusive o fundo de comércio adquirido.

O maior problema quanto ao diferido é sua avaliação. Como em regra só serão incluídos aqui os ativos adquiridos externamente ${ }^{64}$, estes serão usualmente avaliados pelo custo incorrido na aquisição deduzido do saldo da respectiva conta de amortização.

${ }^{64}$ Pode-se dizer praticamente pacífico na doutrina contábil que não se deve incluir no balanço o valor dos bens imateriais (como marcas, patentes, clientela, fundo de comércio ou good will) criados internamente, mas apenas os adquiridos de terceiros. Isso porque não há segurança e objetividade suficientes na estimação de 
No entanto, poderá haver bens e direitos classificáveis no diferido cuja vida útil em que produzirão benefícios econômicos à companhia seja indefinida, caso em que as normas internacionais de contabilidade recomendam somente uma análise periódica para revisão de seu valor.

Deve-se lembrar que todo o cuidado deve ser tomado na avaliação do que escriturar no ativo imobilizado, somente incluindo algum valor sob essa rubrica se tiver razoável grau de certeza de que o gasto incorrido beneficiará exercícios futuros. Todo cuidado é pouco, pois, ativando um valor que poderia ou deveria ser considerado como despesa, a companhia pode falsificar seus resultados, tornando artificialmente maior seu lucro líquido.

\subsection{O passivo}

Genericamente, o passivo abrange todas as obrigações e dívidas da sociedade.

Nos termos do art. 180 da Lei n. 6.404/76, as obrigações da companhia, inclusive financiamentos para aquisição de direitos do ativo permanente, serão classificadas no passivo circulante, quando se vencerem no exercício seguinte, e no passivo exigível a longo prazo, se tiverem vencimento em prazo maior, observado o disposto no parágrafo único do artigo 179.

Por sua vez, o art. 184 estipula que:

Art. 184. No balanço, os elementos do passivo serão avaliados de acordo com os seguintes critérios:

um valor para referidos bens e direitos, fato que daria margem a grande subjetividade por parte da companhia em suas demonstrações. 
I - as obrigações, encargos e riscos, conhecidos ou calculáveis, inclusive Imposto sobre a Renda a pagar com base no resultado do exercício, serão computados pelo valor atualizado até a data do balanço;

II - as obrigações em moeda estrangeira, com cláusula de paridade cambial, serão convertidas em moeda nacional à taxa de câmbio em vigor na data do balanço;

III - as obrigações sujeitas à correção monetária serão atualizadas até a data do balanço.

Dessa forma o passivo compreende as obrigações com fornecedores, os empréstimos e financiamentos da empresa, as dívidas trabalhistas e tributárias, as provisões para exigibilidades futuras, etc.

Mas, principalmente, deve-se compreender que o passivo representa como um todo, essencialmente, a fonte de financiamento de terceiros para a empresa, ou seja, o capital que terceiros empregam no empreendimento. Assim, um fornecedor, emprestando quantias em dinheiro a uma sociedade anônima, possibilita, dentro de certos parâmetros, o desenvolvimento empresarial. Um trabalhador que deixe ali sua força de trabalho também dá sua contribuição para tal fenômeno. Isso tudo é demonstrado pelo passivo.

Neves e Viceconti ${ }^{65}$ apresentam interessante e simples classificação do passivo (capital de terceiros), que englobaria:

- Débitos de funcionamento: são recursos obtidos para o funcionamento normal da empresa, por exemplo: fornecedores, salários a pagar, impostos a pagar;

\footnotetext{
${ }^{65}$ NEVES, Silvério das; VICECONTI, Paulo Eduardo Vilchez. Op. cit., 2000. p. 3.
} 
- Débitos de financiamento: recursos obtidos para a ampliação e desenvolvimento da empresa, tais como os decorrentes de debêntures e empréstimos a longo prazo.

Sabida sua definição e conteúdo, o passivo não contém maiores dificuldades, à semelhança do que já discutimos a respeito do ativo, nem existe necessidade de que se abram aqui tópicos para a discussão em separado do circulante e do exigível a longo prazo.

Estes últimos, aliás, do mesmo modo que ocorre com o ativo circulante e o realizável a longo prazo, não diferem ontologicamente entre si, separando-se apenas pelo período em que serão exigíveis: se antes do final do exercício seguinte ao balanço de encerramento, estarão no circulante; após, estarão no exigível a longo prazo. A natureza das contas que compõem cada grupo não difere entre si.

Nos termos da redação dada pela Lei n. 11.638/07 ao art. 184, II, da Lein. 6.404/76, as obrigações, encargos e riscos classificados no passivo exigível a longo prazo serão ajustados ao seu valor presente, sendo os demais ajustados quando houver efeito relevante.

Vejamos alguns tipos mais comuns de escrituração do passivo.

Os empréstimos serão contabilizados pela inclusão do valor recebido em caixa (débito em disponibilidades) e crédito em conta respectiva de passivo (p. ex.: “empréstimos a pagar" ou "financiamentos"). Os juros dos empréstimos serão contabilizados no resultado (p. ex.: "despesas financeiras"), sendo que a contrapartida poderá ser na mesma conta referente ao empréstimo ou em conta separada de passivo (possibilitando uma melhor visualização dos valores escriturados a título de juros).

As dívidas com fornecedores normalmente são escrituradas em contas particulares para cada qual (crédito de contas de passivo), em contrapartida do débito do ativo correspondente ao fornecimento (p. ex.: "estoques", "máquinas", etc.). 
As provisões constantes do passivo ${ }^{66}$ normalmente são destinadas à constituição de uma cobertura financeira para eventos aleatórios (p. ex.: a provisão para indenizações ou contingências trabalhistas), ou até mesmo com previsibilidade concreta e próxima (p. ex.: a provisão para décimo terceiro salário e férias, feita alguns meses antes do pagamento efetivo). São constituídas a crédito de uma conta de passivo e a débito de uma conta de despesa.

Os tributos devidos pela empresa poderão constar de uma provisão (p. ex.: "provisão para imposto de renda") ou de uma conta de passivo própria (p. ex.: "imposto de renda a recolher"), sempre com uma contrapartida em despesa. No caso de tributos recuperáveis, deve-se confrontar a conta de passivo com a conta respectiva de ativo representativa dos créditos tributários (p. ex.: "ICMS ou IPI a recuperar") para se obter o valor devido a recolher aos cofres públicos.

Os pagamentos devidos aos trabalhadores têm disciplina específica na escrituração, conforme o tipo da verba devida ${ }^{67}$.

Os salários deverão ser provisionados (p. ex.: "provisão para pagamento de salários") no mês de competência, com a correspondente despesa em contrapartida. Quando do pagamento, deve-se baixar a provisão contra o crédito em disponibilidades pela saída de dinheiro. Os encargos sociais (principalmente as contribuições da empresa ao INSS e ao FGTS) devem ser escriturados da mesma forma.

Já as contribuições que a empresa recolhe dos empregados para repassar ao INSS e o Imposto de Renda Retido na Fonte (IRRF) seguem disciplina diversa, devendo ser descontados da provisão para salários, criando-se uma conta específica para tanto (p. ex.: "contribuições a recolher sobre a folha de salários" ou "Imposto de Renda Retido na Fonte a recolher").

\footnotetext{
${ }^{66}$ As provisões podem existir tanto no ativo (retificando parcela deste ou conta específica), como é o caso da provisão para devedores duvidosos, quanto no passivo (quando representam normalmente exigibilidades futuras e de vencimento aleatório). Sua contrapartida será sempre uma conta de resultado (despesa). Voltaremos mais adiante na discussão de sua distinção com as reservas.

${ }^{67}$ As normas internacionais de contabilidade (IFRS) determinam as formas de divulgação de informações e contabilização de pagamentos a empregados (com opções e ações), benefícios previdenciários, entre outros.
} 
Dessa forma, a escrituração da folha de pagamento pode ser feita em cinco partes, conforme ensina Osni Moura Ribeiro: "1) apropriação das despesas com salários; 2) registro dos descontos; 3) apropriações de encargos sociais; 4) pagamento aos empregados em dinheiro; 5) recolhimento das demais obrigações conforme folha" ${ }^{\text {. }}$.

Os dividendos serão escriturados conforme exista ou não distribuição da assembléia a respeito de sua aprovação. Aprovados, deverão ser contabilizados retirando o montante respectivo da conta "lucros e prejuízos acumulados", "lucro líquido do exercício" ou "reserva de lucros", creditando o valor em conta de passivo (p. ex.: "dividendos a pagar”). Caso não tenham sido aprovados em assembléia, poderão constar como valores provisionados.

Serão classificadas no passivo também as receitas antecipadas. Tal grupo é caracterizado pelo recebimento antecipado de determinado bem ou quantia em dinheiro, antes que se realize a transferência efetiva da coisa ao adquirente ou a prestação de serviços ao cliente. Temos aqui um outro caso de aplicação do princípio da confrontação entre receita e despesa, já abordado anteriormente neste trabalho.

É o caso, por exemplo, do cliente que paga antecipadamente para a realização de um serviço futuro, ainda não prestado. A sociedade não poderá escriturar tal valor como receita, até mesmo pelo fato de que, ainda não tendo prestado o serviço, estará sujeita à devolução de seu valor caso o cliente desista antes da prestação. Outrossim, não há ainda nesse momento a contabilização das despesas que serão necessárias à prestação de serviços contratada (p. ex., a contratação de pessoal, compra de insumos, etc.).

Destarte, a escrituração deverá contemplar a quantia recebida no exemplo ora tratado como receita antecipada, inserindo-a no passivo, com a contrapartida nas disponibilidades (pela entrada de dinheiro). Justifica-se a inclusão no passivo de referida quantia, uma vez que, ao receber antecipadamente para a prestação do serviço, a sociedade contraiu, na verdade, uma obrigação em prestá-lo.

${ }^{68}$ RIBEIRO, Osni Moura. Contabilidade intermediária. São Paulo: Saraiva, 2005. p. 125-6. 


\subsubsection{Os resultados de exercícios futuros}

De acordo com o art. 181 da Lei n. 6.404/76, temos que:

Art. 181. Serão classificadas como resultados de exercício futuro as receitas de exercícios futuros, diminuídas dos custos e despesas a elas correspondentes".

O que incluir nesse tópico é matéria divergente entre os autores mais renomados.

Modesto Carvalhosa assevera: "Receitas de exercícios futuros correspondem a um acréscimo no ativo da companhia (dinheiro recebido ou direito de crédito) que ocorre antes de a companhia cumprir a sua obrigação contratual, o que normalmente corresponde à entrega da coisa, ou à prestação do serviço (...) As chamadas receitas de exercícios futuros normalmente ocorrem em contratos de empreitadas, em que é contratada a execução de uma determinada obra, assim como em contratos de compra e venda de coisa a ser produzida, ou contrato de prestação de serviços. Pode ocorrer também em transações financeiras, quando os juros e demais receitas financeiras são recebidos antecipadamente" 69 .

Osni Moura Ribeiro ressalta que: "No grupo resultados de exercícios futuros do passivo, são classificadas as contas que representam entradas de recursos financeiros no Ativo Circulante, decorrentes de receitas as quais, por serem recebidas antecipadamente, e em decorrência do princípio da competência, não foram consideradas na apuração do resultado, ${ }^{, 70}$.

${ }^{69}$ CARVALHOSA, Modesto; LATORRACA Nilton. Op. cit., 1998. v. 3, p. 597.

${ }^{70}$ RIBEIRO, Osni Moura. Contabilidade avançada. São Paulo: Saraiva, 2005. p. 265. 
José Carlos Marion, divergindo, aduz que "A princípio pode parecer que todas as antecipações deverão fazer parte deste grupo. No entanto, recebimentos antecipados (adiantamentos), para os quais haja a obrigação de devolução por parte da empresa (por quaisquer motivos), deverão ser classificados no Passivo Exigível, uma vez que há o risco de devolução. Assim, entre os casos que poderemos incluir no REF, destacamos o 'Aluguel Recebido Antecipadamente' cujo contrato de locação estabeleça cláusula de não reembolso, mesmo que o locatário devolva o imóvel ou qualquer outro bem antes do término do contrato" ${ }^{71}$.

Concordando com este último autor estão Iudícibus et al., para quem: "Somente devem englobar tais receitas menos despesas, ou seja, resultados futuros recebidos, mas para os quais não haja qualquer tipo de obrigação de devolução por parte da empresa"72. Referidos autores não admitem a inclusão no grupo em comento de adiantamentos recebidos de clientes por conta de fornecimento de bens, serviços ou de obras por empreitada.

Parece-nos que o critério adotado pelos últimos autores seja o mais acertado, por fazer constar as receitas antecipadas recebidas com a obrigação de devolução no passivo exigível (circulante ou a longo prazo). No caso de a devolução ser dispensada contratualmente, teremos resultados de exercícios futuros.

Os montantes escriturados neste grupo deverão ser inseridos com a dedução de todas as despesas inerentes às receitas percebidas ou necessárias a sua percepção. Caso as despesas venham a ultrapassar as receitas, há certa divergência doutrinária.

Para Modesto Carvalhosa, "A lei não contempla de forma expressa a hipótese de os custos ultrapassarem a receita no final do exercício social. Entendemos que, nesse caso, o valor líquido deveria figurar no ativo realizável”,73.

Iudícibus et al. aduzem que: "Quando as despesas excederem as receitas, deve-se considerar tal excesso imediatamente como prejuízo. Assim o exige o

\footnotetext{
${ }^{71}$ MARION, José Carlos. Contabilidade empresarial. São Paulo: Atlas, 1997. p. 330.

${ }^{72}$ IUDÍCIBUS, Sérgio de; MARTINS, Eliseu; GELBCKE, Ernesto Rubens. Op. cit., ,2003. p. 285.

${ }^{73}$ CARVALHOSA, Modesto; LATORRACA Nilton. Op. cit., 1998, v. 3, p. 597.
} 
conservadorismo (...) a não ser que isso se deva ao fato de a empresa já haver pago as despesas, mas recebido apenas uma parte da receita (não suficiente para cobri-las). Nesse caso, o saldo devedor deverá figurar no Realizável a Longo Prazo ou no Ativo Circulante, conforme o caso". ${ }^{74}$.

Concordamos com os últimos autores citados. Se as despesas superarem as receitas (ressalvado o caso por estes excepcionado), não há razão para que constem valores no ativo, uma vez que não há crédito da sociedade, devendo ser reconhecido um prejuízo.

\subsection{O patrimônio líquido}

De acordo com a chamada equação fundamental da contabilidade, o patrimônio líquido é o resultado da diferença entre o ativo e o passivo.

Do mesmo modo que o passivo, o patrimônio líquido representa uma fonte de financiamento da sociedade. Difere do passivo, entretanto, por representar o capital próprio investido pelos sócios na sociedade, inversamente ao passivo, que representa o capital de terceiros em referida situação.

Não obstante a distinção acima, verifica-se que há autores que classificam o patrimônio líquido juntamente com o passivo, por verem um grande número de semelhanças entre estes. É o caso de José Carlos Marion, nos seguintes termos: "Na verdade, pela Lei das Sociedades Anônimas, entende-se como passivo todo o lado direito do balanço patrimonial, incluindo resultados de exercícios futuros e patrimônio líquido. Portanto, o lado direito do balanço que reflete todas as fontes de recursos é constituído de passivo exigível, resultados de exercícios futuros e patrimônio líquido"75.

\footnotetext{
${ }^{74}$ IUDÍCIBUS, Sérgio de; MARTINS, Eliseu; GELBCKE, Ernesto Rubens. Op. cit., 2003. p. 285.

${ }^{75}$ MARION, José Carlos. Op. cit., 1997. p. 337.
} 
Em uma sociedade anônima, compõem ordinariamente as contas de patrimônio líquido aquelas referentes ao capital social, aos lucros e prejuízos acumulados e às reservas.

Passaremos em revista os principais tipos de escrituração referentes a cada uma das espécies de contas supracitadas.

\subsubsection{O capital social}

No que tange ao capital social, assevera Fábio Ulhoa Coelho: " $A$ companhia, para dar início à sua atividade, econômica, necessita evidentemente de recursos, isto é, de máquinas, tecnologia, serviços, trabalho e outros meios indispensáveis à organização da empresa abrangida no objeto social. Cabe aos sócios prover tais recursos. Fazem-no, transferindo de seu patrimônio ao da pessoa jurídica, a propriedade de dinheiro, bem ou crédito, e recebendo, em troca, ações emitidas pela sociedade, em valor correspondente. Uma vez iniciada a atividade, pode ocorrer de a sociedade necessitar de mais recursos, e os acionistas, pela maioria com direito de voto dos reunidos em assembléia geral, entenderem que é o caso de ampliar a contribuição deles para o desenvolvimento da empresa. Mais dinheiro, bens ou créditos são, então, transferidos do patrimônio dos sócios para o da sociedade, em contrapartida do recebimento de novas ações. Esses aportes são apropriados, na contabilidade da companhia, como capital social (...) O capital social pode ser entendido, nesse sentido, como uma medida da contribuição dos sócios para a sociedade anônima, e acaba servindo, em um certo modo, de referência à sua força econômica. Capital elevado sugere solidez, uma companhia dotada de recursos próprios, suficientes ao atendimento de suas necessidades de custeio (...) Importante ressaltar, para concluir, que o capital social não mede o total da contribuição dos sócios quando as ações são subscritas a preço superior ao valor nominal. Nessa situação, a parte do preço que supera o valor nominal (denominada ágio) deve ser contabilizada pela companhia não na conta do capital social, mas como reserva de capital (...) Ainda no plano do rigor conceitual, deve-se levar em conta que o capital social pode 
ser aumentado com recursos provenientes de lucros ou reservas, os quais não são aportes feitos pelos sócios, mas frutos do desenvolvimento da própria empresa. Com o passar do tempo, portanto, o capital social deixa de representar apenas a contribuição dos sócios"76.

A forma de escrituração do capital social de uma sociedade anônima normalmente é feita através do uso de duas contas de patrimônio líquido (p. ex.: "capital a integralizar" e "capital subscrito"), com possível contrapartida no ativo.

Quando da subscrição do capital (p. ex.: de $\mathrm{R} \$$ 500.000,00, sem nenhum valor em dinheiro ingressando no caixa da sociedade), deve-se creditar referido valor a débito de capital a integralizar e a crédito de capital subscrito. Veja-se que aqui não existe contrapartida no ativo, pois os sócios não transferiram qualquer valor à sociedade ${ }^{77}$.

Suponhamos o mesmo caso anterior, vindo os sócios a integralizar uma parte (p. ex.: R\$ 200.000,00). Nesse caso, deve-se debitar uma conta pertencente ao disponível (caixa, bancos, etc.) pela entrada de dinheiro, com a contrapartida a crédito na conta “capital a integralizar" (o qual restará com R 500.000,00 - R \$200.000,00 = R \$ 300.000,00). O balanço de uma sociedade anônima nessa situação ficaria assim:

\begin{tabular}{|c|c|c|c|}
\hline \multicolumn{2}{|c|}{ Ativo } & \multicolumn{2}{|c|}{ Passivo e PL } \\
\hline \multirow[t]{2}{*}{ Disponível } & \multirow[t]{2}{*}{$200.000,00$} & & \\
\hline & & $\begin{array}{c}\text { Capital subscrito } \\
\text { Capital a } \\
\text { integralizar }\end{array}$ & $\begin{array}{c}500.000,00 \\
(300.000,00)\end{array}$ \\
\hline Total & $200.000,00$ & Total & $200.000,00$ \\
\hline
\end{tabular}

O capital integralizado é obtido pela diferença entre as contas "capital subscrito" e "capital a integralizar", cumprindo-se, assim, o que preceitua a Lei n. 6.404/76, nos termos a seguir transcritos:

\footnotetext{
${ }^{76}$ COELHO, Fábio Ulhoa. Op. cit., 2003. v. 2, p. 158.

${ }^{77}$ Se a sociedade não possuir mais nenhum outro recurso, seu balanço totalizará valor zerado, pois não haverá ativos (lado esquerdo do balanço) e o passivo será anulado pela diferença de valores iguais entre uma conta credora (capital subscrito) e outra devedora (capital a integralizar).
} 
Art. 182. A conta do capital social discriminará o montante subscrito e, por dedução, a parcela ainda não realizada ${ }^{78}$.

Caso as ações sejam adquiridas com ágio (quantia além do valor nominal), a escrituração deste não deve permanecer nas contas de capital. Estas devem refletir tãosomente o valor nominal das ações e nada mais. Os valores excedentes do valor nominal devem ser escriturados em conta de reserva de capital, nos termos do art. 182 , § $2^{\circ}$, da Lei n. 6.404/76:

$\S 1^{o}$ Serão classificadas como reservas de capital as contas que registrarem:

a) a contribuição do subscritor de ações que ultrapassar o valor nominal e a parte do preço de emissão das ações sem valor nominal que ultrapassar a importância destinada à formação do capital social, inclusive nos casos de conversão em ações de debêntures ou partes beneficiárias;

Imaginemos que determinado acionista adquira um lote de 100 ações com preço unitário de $\mathrm{R} \$ 2,00$ e valor nominal de $\mathrm{R}$ \$ 1,00. O valor total pago pelo acionista será de $\mathrm{R}$ \$200,00 (100 ações x R \$2,00), correspondentes ao ingresso de valores em caixa. Na escrituração, porém, entrarão no capital somente $R$ \$ 100,00, sendo que os outros $R$ \$ 100,00 serão contabilizados em conta de reserva de capital (p. ex.: "reserva de capital ágio na emissão de ações”).

Em termos práticos, teremos: 1) disponível ( $\mathrm{R}$ 200,00 - débito); 2) capital ( $\mathrm{R} \$ 100,00$ - crédito); 3) reserva de capital ( $\mathrm{R}$ \$ 100,00 - crédito).

Cumpre analisar a escrituração em casos de companhias com capital autorizado, nas quais seja permitido um aumento de capital pelos órgãos administrativos em determinados limites, sem a alteração do estatuto.

\footnotetext{
${ }^{78}$ Dedução considerada neste artigo não é o processo lógico segundo o qual, partindo de uma regra geral, pode-se chegar a uma conclusão para determinado caso concreto. Aqui, o termo está empregado em sentido contábil-matemático, significando diminuição, ou subtração.
} 
Costuma-se em tal hipótese subdividir a conta "capital subscrito" em duas subcontas: "capital autorizado" e "capital a subscrever". Exemplificando: se uma companhia possui um limite de capital de $\mathrm{R} \$ 1.000 .000,00$ e os sócios subscreveram R\$ 500.000,00, integralizando $\mathrm{R} \$ 200.000,00$, teremos:

Capital subscrito

Capital autorizado

(-) Capital a subscrever

(-) Capital a realizar
$\mathrm{R} \$ 500.000,00$ $\mathrm{R} \$ 1.000 .000,00$

$\mathrm{R} \$(500.000,00)$

O capital realizado seria a diferença entre o capital subscrito ( $R$ \$ $500.000,00)$ e o capital a subscrever ( $\mathrm{R} \$ 300.000,00)$, ou seja, $\mathrm{R} \$ 200.000,00$.

É importante verificar, por também fazer parte do tema inerente à escrituração, que o ordenamento jurídico nacional ainda não estabeleceu controles específicos que garantam a segurança da integralização, aumentos e diminuições de capital social $^{79}$.

Ainda há, portanto, grande espaço aberto a fraudes contábeis afetando a conta de capital, que podem prejudicar sócios, credores e o próprio fisco ${ }^{80}$.

\footnotetext{
${ }^{79}$ Em relação às sociedades anônimas, há pequena parcela de controle de realidade do capital social, diante do art. 80 da Lei n. 6.404/76, que obriga, na constituição da companhia, o cumprimento dos seguintes requisitos preliminares: 1) realização, como entrada, de 10\% (dez por cento), no mínimo, do preço de emissão das ações subscritas em dinheiro; 2) depósito, no Banco do Brasil S/A, ou em outro estabelecimento bancário autorizado pela Comissão de Valores Mobiliários, da parte do capital realizado em dinheiro (grifos nossos). Não há instituído, entretanto, controle quanto a reavaliações fraudulentas ou aumentos e diminuições irreais de capital. Em relação às demais sociedades, o controle da realidade do capital social no ordenamento pátrio é praticamente nenhum. Entendemos que aqui não se trata da hipótese (divergente na doutrina) de discutir se o sócio responde pela capitalização insuficiente da sociedade (subcaptalização), uma vez que não se está diante de mera insuficiência de recursos, mas de verdadeira declaração falsa dos sócios diante de credores, fisco e outros sócios. Assim, a responsabilidade civil e criminal pelo ato ilícito ou criminoso, em nossa opinião, resta irrefutável.

${ }^{80}$ Exemplos interessantes de fraude contábil constam da obra de Antônio Lopes de Sá e Wilson Alberto Zappa Hoog, que citam casos em que participaram na função de peritos/auditores, em que houve integralização do capital por imóveis de valor fictício, com troca posterior por títulos incobráveis ou cujos beneficiários eram os próprios sócios (SÁ, Antônio Lopes de; HOOG, Wilson Alberto Zappa. Corrupção, fraude e contabilidade. Curitiba: Juruá, 2005).
} 


\subsubsection{As reservas}

As reservas, que também fazem parte do patrimônio líquido, estão disciplinadas na Lei n. 6.404/76 em seu art. 182 , $\S \S 1^{\circ}$ a $5^{\circ}$, nos seguintes termos:

$\S 1^{o}$ Serão classificadas como reservas de capital as contas que registrarem:

a) a contribuição do subscritor de ações que ultrapassar o valor nominal e a parte do preço de emissão das ações sem valor nominal que ultrapassar a importância destinada à formação do capital social, inclusive nos casos de conversão em ações de debêntures ou partes beneficiárias;

b) o produto da alienação de partes beneficiárias e bônus de subscrição;

$\S 2^{\circ}$ Será ainda registrado como reserva de capital o resultado da correção monetária do capital realizado, enquanto não-capitalizado.

$\S 3^{\circ}$ Serão classificadas como ajustes de avaliação patrimonial, enquanto não computadas no resultado do exercício em obediência ao regime de competência, as contrapartidas de aumentos ou diminuições de valor atribuído a elementos do ativo ( $\$ 5^{\circ}$ do art. 177, inciso I do caput do art. 183 e $\S 3^{\circ}$ do art. 226 desta Lei) e do passivo, em decorrência da sua avaliação a preço de mercado;

$\S 4^{\circ}$ Serão classificados como reservas de lucros as contas constituídas pela apropriação de lucros da companhia.

$\S 5^{\circ}$ As ações em tesouraria deverão ser destacadas no balanço como dedução da conta do patrimônio líquido que registrar a origem dos recursos aplicados na sua aquisição. 
Interessante verificar a definição de Fran Martins: “As reservas, genericamente, representam a separação de parcelas dos resultados do exercício social, constituindo apropriação do lucro que seria distribuível, para garantia do patrimônio líquido da companhia. Hermann Júnior, citando Gino Zappa, define as reservas como 'quotas ideais do patrimônio, acrescidas ao valor nominal do capital social, destinadas a fazer frente a riscos de vária natureza ou aumentar o chamado fundo de operação ou de exercício'. Com efeito, caso a companhia distribuísse entre seus acionistas todos os ganhos que apurasse ao final do exercício, não teria evidentemente condições para se expandir elou continuar operando. São elas, como diz Erymá Carneiro, incrementos à potencialidade econômica da empresa" ${ }^{\text {81. }}$.

As reservas estão subdivididas $\mathrm{em}^{82}$ :

- De capital: estabelecidas com valores recebidos não oriundos do resultado empresarial. Compõe-se de contribuições de subscritores de valores mobiliários, etc.;

- De reavaliação (ajustes de avaliação patrimonial): formadas pela atualização dos valores dos ativos da companhia;

- De lucros: elaboradas através de parcela do resultado da empresa;

- De incentivos fiscais: quando houver destinação para a reserva de incentivos fiscais de parcela do lucro líquido decorrente de doações ou subvenções governamentais para investimentos, a qual poderá ser excluída da base de cálculo do dividendo obrigatório.

As reservas de reavaliação são oriundas de atualização dos valores de ativos (ou passivos) da companhia, ou mesmo de suas coligadas ou controladas, quando avaliadas

\footnotetext{
${ }^{81}$ MARTINS, Fran. Comentários à lei das sociedades anônimas. Rio de Janeiro: Forense, 1984. p. 599.

${ }^{82}$ As normas internacionais de contabilidade (IFRS) ainda preceituam a formação de mais três tipos de reservas: 1) reservas de tradução: destinadas a conter contrapartidas derivadas de conversão de demonstrações contábeis para moeda estrangeira; 2) reservas de instrumentos financeiros: destinadas a receber contrapartidas de ajustes de instrumentos financeiros a valor de mercado; 3) reservas de opções de ações.
} 
pelo método de equivalência patrimonial. Sua contabilização deve ser feita, em um primeiro momento, pelo acréscimo a débito na conta de ativo atualizada, com a contrapartida na reserva de reavaliação respectiva.

Quanto a estas, o principal problema que se põe aqui é o de saber como se dará a baixa no ativo reavaliado e na conta de reserva inerente. Ordinariamente, recomenda-se a transferência dos valores inseridos nas reservas de reavaliação para a conta de lucros ou prejuízos acumulados conforme o uso e desgaste do ativo por depreciação, amortização ou exaustão, ou nas hipóteses de baixa e alienação.

As reservas de lucro são as que possuem maior número de subdivisões: 1) reserva de lucros; 2) reserva estatutária; 3) reserva para contingências; 4) reservas de lucros a realizar; 4) reserva de lucros para expansão; 5) reserva especial para dividendo obrigatório não distribuído.

Sua disciplina é feita nos arts. 193 e ss. da Lei n. 6.404/76:

A escrituração das reservas de lucros é também razoavelmente simples, debitando-se conta específica de lucro do exercício ou conta de lucros e prejuízos acumulados, com o crédito correspondente na conta de reserva de lucros.

\subsection{3 (Lucros e) prejuízos acumulados ${ }^{83}$}

A conta lucros e prejuízos acumulados é a conexão das contas patrimoniais com as contas de resultado e, por conseqüência, representa a ponte entre o balanço patrimonial e a demonstração de resultado do exercício.

${ }^{83}$ Com a superveniência da Lei n. 11.638/07, a conta "Lucros e prejuízos acumulados" foi denominada meramente "prejuízos acumulados". Mantivemos a denominação original no curso do texto, com a presente ressalva. 
Os lançamentos em referida conta são feitos após as contas de resultado (incluindo receitas e despesas) serem liquidadas, em contrapartida de conta de apuração do resultado do exercício. O saldo desta última (lucro ou prejuízo líquidos do exercício) será levado para lucros e prejuízos acumulados, zerando a conta de apuração. A demonstração do saldo final será feita no balanço patrimonial, de forma acumulada com os resultados de exercícios anteriores (daí receber o nome de "acumulados").

Há duas formas distintas de apresentar a conta lucros ou prejuízos acumulados: englobada ou separadamente. $\mathrm{Na}$ primeira forma, haverá uma única conta abrangendo lucros e/ou prejuízos (se credora, indicará lucros acumulados, se devedora, prejuízos acumulados). Na segunda, desdobram-se duas contas, uma para representar os lucros acumulados e outra representando os prejuízos acumulados.

Para as companhias abertas, a Comissão de Valores Mobiliários (CVM), na Instrução 59/86, delimitou o campo de valores que pode ser representado nesta conta conforme a seguir descrito:

Art. $8^{\circ}$ - A conta de lucros acumulados contemplará apenas a parcela relativa a frações de lucros que não possam ser computadas na declaração do dividendo por ação. Poderá ser, ainda, admitida a utilização desta rubrica para abrigar as retenções de lucros na forma do artigo 196 da Lei n. $6.404 / 76$.

Parágrafo único. Somente poderá haver saldo na conta de prejuízos acumulados se esgotadas todas as reservas de lucros, inclusive a reserva legal. Os prejuízos remanescentes, que excederem às reservas de lucros, poderão ser, primeiramente, absorvidos pelas reservas de capital, exceto a correção monetária do capital realizado. 


\section{A ESCRITURAÇÃO NAS SOCIEDADES LIMITADAS E AS DISPOSIÇÕES DO NOVO CÓDIGO CIVIL}

A escrituração das sociedades limitadas obedece hoje ao Capítulo IV, Título IV, Livro III da Parte Especial do Código Civil.

Cumpre salientar que o capítulo supracitado referente à escrituração não se aplica somente às sociedades limitadas, mas a toda sociedade empresária tratada no Código Civil (que possui até mesmo alguns dispositivos regulando as sociedades anônimas) e também ao empresário individual. A única exclusão que faz o Código é referente ao pequeno empresário definido no art. 970 (art. 1.179, § 2º).

Anteriormente ao Código Civil atual, disciplinava a matéria o Dec.-Lei n. 486, de 3 de março de 1969, regulamentado pelo Dec.-Lei n. 64.567, de 22 de maio de 1969.

Dessa forma, estando a sociedade limitada inserida na disciplina geral das sociedades empresárias e não contendo particularidades regidas por leis próprias (como é o caso da sociedade anônima), procederemos ao estudo das normas respectivas de escrituração de modo que englobe as regras gerais aplicáveis aos tipos societários regulados no Código Civil.

Como veremos a seguir, o capítulo referente à escrituração comete sérios desvios em relação aos princípios e postulados consagrados pela ciência contábil, fato não percebido e não evidenciado pela doutrina jurídica ${ }^{84}$.

A crítica ao capítulo se inicia por sua nomenclatura, que abrange menos do que contém. Com efeito, salienta Eliseu Martins a impropriedade de denominá-lo "Da

\footnotetext{
${ }^{84}$ Excelente artigo a respeito foi publicado por MARTINS, Eliseu. Atrocidades contábeis no novo Código
} Civil. Boletim IOB-Thomson, São Paulo, n. 41, ano 2002, partes 1 e 2. 
Escrituração" da forma feita pelo legislador: "Vejamos logo no início do Capítulo IV, impropriamente chamado Da Escrituração. Dizemos impropriamente assim denominado porque dentro dele estão não só a escrituração mas também as demonstrações contábeis. O mais correto é o que faz a Lei das S/A ao chamá-lo de Exercício Social e Demonstrações Financeiras (nesse ponto concordamos com muitos críticos da Lei das S/A: deveriam ser demonstrações contábeis, mas é estranho que no novo Código não apareçam nem uma nem outra expressão ${ }^{„ 85}$.

Independentemente da nomenclatura do capítulo, analisaremos a seguir os dispositivos nele contidos.

Iniciam a temática os arts. 1.179 e 1.180 , nos seguintes termos:

Art. 1.179. O empresário e a sociedade empresária são obrigados a seguir um sistema de contabilidade, mecanizado ou não, com base na escrituração uniforme de seus livros, em correspondência com a documentação respectiva, e a levantar anualmente o balanço patrimonial e o de resultado econômico.

$\S 1^{\circ}$ Salvo o disposto no art. 1.180, o número e a espécie de livros ficam a critério dos interessados.

$\S 2^{\circ}$ É dispensado das exigências deste artigo o pequeno empresário a que se refere o art. 970.

Art. 1.180. Além dos demais livros exigidos por lei, é indispensável o Diário, que pode ser substituído por fichas no caso de escrituração mecanizada ou eletrônica.

\footnotetext{
${ }^{85}$ MARTINS, Eliseu. Op. cit., ano 2002, parte 2, p. 6.
} 
Parágrafo único. A adoção de fichas não dispensa o uso de livro apropriado para o lançamento do balanço patrimonial e do de resultado econômico.

No que tange à matéria referente aos pequenos empresários (art. 1.179, § $2^{\circ}$ ), discutiremos suas repercussões no tópico seguinte.

O modo de escrituração do Diário vem resumido no art. 1.184 do Código Civil, nos seguintes termos:

Art. 1.184. No Diário serão lançadas, com individuação, clareza e caracterização do documento respectivo, dia a dia, por escrita direta ou reprodução, todas as operações relativas ao exercício da empresa.

$\S 1^{o}$ Admite-se a escrituração resumida do Diário, com totais que não excedam o período de trinta dias, relativamente a contas cujas operações sejam numerosas ou realizadas fora da sede do estabelecimento, desde que utilizados livros auxiliares regularmente autenticados, para registro individualizado, e conservados os documentos que permitam a sua perfeita verificação.

$\S 2^{o}$ Serão lançados no Diário o balanço patrimonial e o de resultado econômico, devendo ambos ser assinados por técnico em Ciências Contábeis legalmente habilitado e pelo empresário ou sociedade empresária.

Deve-se notar que o livro Diário consubstancia a escrituração contábil completa (incluindo todas as operações empresariais), sendo que seus lançamentos serão base para a elaboração das demonstrações contábeis.

Sua nomenclatura (Diário) é justamente derivada do período em que os lançamentos são realizados (diariamente). No entanto, o legislador está atento a algumas atividades que não permitirão lançamentos de seu todo, nem mesmo que sejam feitos dia a 
dia. Assim, permite que os lançamentos sejam feitos em períodos maiores (até trinta dias) para as contas que enumera, através da utilização de livros auxiliares, desde que mantida sua documentação respectiva.

Em relação ao $\S 2^{\circ}$, novamente o legislador cometeu um deslize: não existe técnico em ciências contábeis. Há o bacharel em ciências contábeis ou o técnico em contabilidade: técnico em ciências contábeis, não ${ }^{86}$. Veja-se que no art. 1.182 o legislador corrige o engano ressaltando: "Sem prejuízo do disposto no art. 1.174, a escrituração ficará sob a responsabilidade de contabilista legalmente habilitado, salvo se nenhum houver na localidade” (grifos nossos).

Os arts. $1.181,1.183,1.185$ e 1.186 revelam aspectos extrínsecos e intrínsecos da escrituração:

Art. 1.181. Salvo disposição especial de lei, os livros obrigatórios e, se for o caso, as fichas, antes de postos em uso, devem ser autenticados no Registro Público de Empresas Mercantis.

Parágrafo único. A autenticação não se fará sem que esteja inscrito o empresário, ou a sociedade empresária, que poderá fazer autenticar livros não obrigatórios.

Art. 1.183. A escrituração será feita em idioma e moeda corrente nacionais e em forma contábil, por ordem cronológica de dia, mês e ano, sem intervalos em branco, nem entrelinhas, borrões, rasuras, emendas ou transportes para as margens.

Parágrafo único. É permitido o uso de código de números ou de abreviaturas, que constem de livro próprio, regularmente autenticado.

\footnotetext{
${ }^{86}$ Nesse sentido, novamente a observação de MARTINS, Eliseu. Op. cit., ano 2002, parte 1, p. 1.
} 
Art. 1.185. O empresário ou sociedade empresária que adotar o sistema de fichas de lançamentos poderá substituir o livro Diário pelo livro Balancetes Diários e Balanços, observadas as mesmas formalidades extrínsecas exigidas para aquele.

Art. 1.186. O livro Balancetes Diários e Balanços será escriturado de modo que registre:

I - a posição diária de cada uma das contas ou títulos contábeis, pelo respectivo saldo, em forma de balancetes diários;

II - o balanço patrimonial e o de resultado econômico, no encerramento do exercício.

Algumas observações são necessárias aqui.

Primeiramente, o Código Civil reflete posicionamento deveras antiquado ao mencionar livros e fichas. Tais sistemas de escrituração já estão severamente ultrapassados pelas modernas técnicas computacionais. De fato, pouquíssimas são as empresas ou profissionais de contabilidade que utilizam escrituração manual ou mecanizada, ou mesmo dos livros e fichas, muito comuns no passado.

Torna-se praticamente irrelevante nos novos processos de escrituração a existência de borrões, entrelinhas, rasuras, que se referiam mais à escrituração manual ou mecanizada. Saliente-se que, anteriormente à edição do Código Civil, a Instrução Normativa do Departamento Nacional de Registro do Comércio (DNRC) n. 65, de 31 de julho de 1997 (hoje revogada), preceituava que:

Art. $2^{o}$ São instrumentos de escrituração das empresas mercantis:

I - livros; 
II - conjunto de fichas ou folhas soltas;

III - conjunto de folhas contínuas;

IV - microfichas geradas através de microfilmagem de saída direta do computador (COM).

Interessante é o que preceitua o art. 1.186, que possibilita a substituição do livro Diário pelo livro Balancetes Diários e Balanços. Vale aqui novamente relembrar Eliseu Martins a respeito do tema: “Ou seja, existindo balancetes diários, como nos Bancos, eles podem ser colocados na forma de livro e é dispensado o livro Diário! Interessante: pode haver 100.000 lançamentos diários, e não haver Diário, mas se durante um mês a empresa possuir 200 lançamentos e não efetuar balancetes diários terá que tê10,87 .

Se colocarmos em prática as exigências do Código Civil para a substituição do livro Diário pelo livro Balancetes Diários e Balanços, veremos que em pouco ou nada irá diminuir a complexidade da escrituração.

Com efeito, ao levantar um balancete, deverá o profissional encerrar diariamente as contas respectivas, para escriturar aquela demonstração com base em seu saldo final (o que ele poderia fazer, em alguns casos, até em períodos de trinta dias se escriturasse o Diário). Depois, mesmo fazendo os balancetes, terá ainda de fazer o balanço e a demonstração de resultado do exercício (balanço de resultado econômico) no encerramento do exercício (o que também teria de fazer se não fizesse a substituição).

Assim, acreditamos que será quase inaplicável a norma do art. 1.186 do Código Civil.

$\mathrm{O}$ art. 1.187 descreve os procedimentos para levantamento do inventário, nos seguintes termos:

\footnotetext{
${ }^{87}$ MARTINS, Eliseu. Op. cit., ano 2002, parte 2, p. 6.
} 
Art. 1.187. Na coleta dos elementos para o inventário serão observados os critérios de avaliação a seguir determinados:

I - os bens destinados à exploração da atividade serão avaliados pelo custo de aquisição, devendo, na avaliação dos que se desgastam ou depreciam com o uso, pela ação do tempo ou outros fatores, atender-se à desvalorização respectiva, criando-se fundos de amortização para assegurar-lhes a substituição ou a conservação do valor;

II - os valores mobiliários, matéria-prima, bens destinados à alienação, ou que constituem produtos ou artigos da indústria ou comércio da empresa, podem ser estimados pelo custo de aquisição ou de fabricação, ou pelo preço corrente, sempre que este for inferior ao preço de custo, e quando o preço corrente ou venal estiver acima do valor do custo de aquisição, ou fabricação, e os bens forem avaliados pelo preço corrente, a diferença entre este e o preço de custo não será levada em conta para a distribuição de lucros, nem para as percentagens referentes a fundos de reserva;

III - o valor das ações e dos títulos de renda fixa pode ser determinado com base na respectiva cotação da Bolsa de Valores; os não cotados e as participações não acionárias serão considerados pelo seu valor de aquisição;

IV - os créditos serão considerados de conformidade com o presumível valor de realização, não se levando em conta os prescritos ou de difícil liqüidação, salvo se houver, quanto aos últimos, previsão equivalente.

$\mathrm{Na}$ interpretação do dispositivo supracitado, devemos fixar bem o que é inventário. 
De acordo com o Dicionário Aurélio, na acepção ora procurada, inventário é o "Levantamento individuado e completo dos bens e valores ativos e passivos duma sociedade mercantil ou de qualquer entidade econômica" ${ }^{\text {} 88}$.

Também Pontes de Miranda, comentando ainda sob a vigência da anterior disciplina das sociedades anônimas, leciona: "O primeiro passo para se chegar à feitura do balanço do exercício é o de fazer-se o inventário do ativo e do passivo. $O$ inventário supõe a documentação sobre todos os bens, inclusive créditos e direitos formativos, $e$ sobre as dívidas da sociedade por ações, com as indicações suficientes e os valores iniciais ou anuais da atividade e da passividade da empresa. Depois é que se há de pensar na conta de lucros e perdas e no balanço (...) Os bens que compõem o patrimônio social dificilmente mantêm o mesmo valor. Há valorização de uns e desvalorização de outros. Uns que num período se valorizaram, noutro desvalorizam-se; e vice-versa. A escrita pode ser exata e estar em dia, sem que corresponda à situação financeira e econômica da empresa. Por isso, tem-se de proceder ao inventário do ativo e do passivo e à estimação do ativo. Os fatores que se hão de considerar para as avaliações não são mesmos para todos os bens, nem sempre permanecem para os bens que antes foram avaliados. Todos têm de ser estimados em dinheiro" ${ }^{\text {. }}$.

Do modo descrito pelo insigne jurista ora citado, e retratado pelo Código Civil, pode parecer que o inventário seja um longo procedimento de reavaliação de toda a situação patrimonial existente antes do levantamento final do balanço, devidamente documentado e formalizado.

Em verdade, podemos classificar o inventário em dois tipos básicos: físico e contábil.

O inventário contábil é retirado das contas escrituradas, livros obrigatórios e livros auxiliares analíticos, como o Registro de Inventário, Registro de Duplicatas, Caixa, etc.

\footnotetext{
${ }^{88}$ Novo Dicionário Aurélio da Língua Portuguesa. Curitiba: Editora Positivo. 1 CD-ROM.

${ }^{89}$ MIRANDA, Pontes de. Op. cit., 1983. t. L, p. 426.
} 
O inventário físico se consubstancia na contagem física de itens do ativo, muito utilizado para a verificação de elementos de estoques, matérias-primas, produtos em elaboração ou acabados.

A realidade dos dias atuais, principalmente com a utilização de mecanismos de informática, não confirma a extrema relevância dada no passado aos processos de inventário, sobretudo no que diz respeito a inventários contábeis.

Parece que nessa matéria, mais uma vez, o Código Civil restou atrelado a antigas concepções de escrituração, dos tempos de antanho, principalmente às disposições do Decreto-Lei n. 2.627, de 26 de setembro de 1940, e alterações (antiga regulamentação das sociedades anônimas), que apresentam conceitos deveras ultrapassados ${ }^{90}$.

Para bens do ativo circulante, componentes das disponibilidades financeiras da empresa, pouco ou nada haverá normalmente a inventariar, restando a mera visualização de contas previamente escrituradas. De fato, expressando-se esses itens em dinheiro, assim eles serão retratados no balanço. Havendo divergência entre os dados bancários e os dados escriturados, proceder-se-á à simples conciliação bancária.

${ }^{90}$ Vejam-se os dispositivos do Decreto-Lei n. 2.627, que seguramente foram a fonte do legislador que elaborou o art. 1.187 do Código Civil: “Art. 129. No fim de cada ano ou exercício social, proceder-se-á a balanço geral, para a verificação dos lucros ou prejuízos. $\$ 1^{\circ}$ Feito o inventário do ativo e passivo, a estimação do ativo obedecerá às seguintes regras: (Redação dada pela Lei $n .5 .589$, de 1970) a) os bens, destinados à exploração do objeto social, avaliar-se-ão pelo custo de aquisição. Na avaliação dos que se desgastam ou depreciam com o uso ou pela ação ao tempo ou de outros fatores, atender-se-á à desvalorização respectiva, devendo ser criados fundos de amortização para assegurar-lhes a substituição ou a conservação do valor; b) os valores mobiliários, matéria-prima, bens destinados à alienação, ou que constituem produtos ou artigos da indústria ou comércio da sociedade, podem ser estimados pelo custo de aquisição ou de fabricação, ou pelo preço corrente no mercado ou Bolsa. Prevalecerá o critério da estimação pelo preço corrente, sempre que este for inferior ao preço do custo. Quando o preço corrente ou venal estiver acima do valor do custo de aquisição ou fabricação, se avaliados os bens pelo preço corrente, a diferença entre este e o preço do custo não será levada em conta para a distribuição de dividendos, nem para as percentagens referentes aos fundos de reserva; c) não se computarão no ativo os créditos prescritos ou de difícil liquidação, salvo se houver, quanto aos últimos, reserva equivalente; d) entre os valores do ativo poderão figurar as despesas de instalação da sociedade, desde que não excedam de $10 \%$ (dez por cento) do capital social e sejam amortizadas anualmente; e) nas despesas de instalação deverão ser incluídos os juros pagos aos acionistas durante o período que anteceder o início das operações sociais. Os estatutos fixarão a taxa de juro, que não poderá exceder de $6 \%$ (seis por cento) ao ano, e o prazo para a amortização. $\S 2^{\circ}$ As sociedades registradas em Bolsas de Valores ficam obrigadas a remeter às entidades junto às quais mantenham registro, até 30 (trinta) dias após o enceramento do primeiro e segundo semestres do seu exercício anual, um balanço econômico-financeiro provisório, demonstrativo dos resultados, com esclarecimentos necessários, que serão afixados pelas Bolsas. (Incluído pela Lei $n$. 5.589, de 1970) $\$ 3^{\circ} \mathrm{O}$ Conselho Monetário Nacional estabelecerá os critérios de padronização dos documentos de que trata os $\$ 2^{\circ}$ podendo ainda, autorizar o Banco Central do Brasil a prorrogar o prazo neste estabelecido determinado então, as condições a que estarão sujeitas as sociedades beneficiárias da prorrogação. (Incluído pela Lei $n$. 6.024, de 1974) (Revogado pela Lei n. 6.404, de 1976)”. 
Em regra, será desnecessária a escrituração das valorizações do estoque e dos demais bens componentes do ativo permanente: vigendo o princípio custo ou valor de mercado, dos dois o menor, os valores assumidos no balanço para o ativo serão os custos históricos de aquisição, salvo se os valores de mercado dos bens forem inferiores, caso em que se fará mera provisão de ajuste. A mencionada necessidade de atualização de valores, na verdade, não existe.

A reavaliação de valores de bens será restrita, pois, a determinados casos concretos e a determinados tipos de bens, não sendo tomada como regra geral.

Alguns casos em que sempre existirá renovação de valores são aqueles referentes aos investimentos avaliados pelo método de equivalência patrimonial. Mas aqui, em regra, o processo será meramente o de aplicar um percentual de participação de uma sociedade investidora sobre o patrimônio líquido de outra (investida), após o levantamento do balanço desta última.

Do mesmo modo, em relação ao passivo, não se fazem necessários tamanhos levantamentos, quanto pode fazer crer o Código Civil. As dívidas sociais são atualizadas pela correção monetária e pelos juros. Estes devem ser devidamente lançados a seu tempo, conforme a época de competência respectiva.

As variações monetárias devem também ser feitas na data do levantamento do balanço.

Incumbe mencionar que a correção monetária das demonstrações contábeis foi extinta pela Lei n. $9.249 / 95^{91}$.

Assim, o inventário será utilizado com a finalidade precípua de fazer a contagem física dos bens componentes do estoque (essa, aliás, a concepção e finalidade que lhe dá a doutrina contábil). Para tanto, formularam-se dois sistemas básicos:

${ }^{91}$ Art. $4^{\circ}$ Fica revogada a correção monetária das demonstrações financeiras de que tratam a Lei $n$. 7.799, de 10 de julho de 1989, e o art. $1^{\circ}$ da Lei n. 8.200, de 28 de junho de 1991. 
- Inventário periódico: nesse sistema, a sociedade empresária ou o empresário individual não darão baixa ${ }^{92}$ em seu estoque a cada venda efetuada ou serviço prestado. Periodicamente, porém, é realizada a contagem física do estoque, procedendo-se à baixa respectiva;

- Inventário permanente: no sistema de inventário permanente, a cada venda efetuada ou serviço prestado, é efetuada a baixa respectiva do estoque. Mesmo neste método, por vezes é necessária a contagem física do estoque, dadas as freqüentes perdas involuntárias.

Mas o principal problema do atual Código está no inciso I do art. 1.187, ao disciplinar a depreciação dos bens componentes do imobilizado. Descreve o dispositivo que "na avaliação dos que se desgastam ou depreciam com o uso, pela ação do tempo ou outros fatores, atender-se à desvalorização respectiva, criando-se fundos de amortização para assegurar-lhes a substituição ou a conservação do valor”.

Tal dispositivo correspondia à exata redação do Decreto-Lei n. 2.627/40, já mencionado, e recebeu o seguinte comentário do insigne Pontes de Miranda: "Na avaliação dos bens desgastáveis e depreciáveis, ao fim de cada exercício tem-se de atender à desvalorização em relação ao custo da aquisição. Para que se cubra, deve ser criado um fundo de reserva, dito fundo de amortização, porém a que melhor se chamaria fundo de cobertura, pois que é fundo com que se cobrem perdas eventuais. Se, com o fundo de cobertura, se adquiriram bens que equivalem à diminuição, exatamente para se restaurar o valor do ativo, pode ser mantido o valor do último inventário (...) Quanto ao valor dos bens destinados à exploração, a depreciação pelo uso ou desgaste nada tem com a depreciação no mercado, porque a empresa apenas há de levar em conta a necessidade da substituição, dos consertos e das atualizações, que correm pelo fundo de cobertura”.

Um pouco adiante explica o jurista que os fundos de reserva "São provisões que se fazem para futuras inversões: os valores ativos ficam de parte, reservados, para que não se distribuam entre os acionistas. Para que eles subsistam às inversões, é preciso

\footnotetext{
${ }^{92}$ A baixa nos estoques é feita através de lançamento a crédito na conta de estoque e a débito na conta de Custos das Mercadorias Vendidas (CMV), Custos dos Serviços Prestados (CSP) ou Custos dos Produtos Vendidos (CPV), componentes do resultado, conforme se trate de empresa que atue no ramo comercial, de prestação de serviços ou industrial.
} 
que se reconstituam, conforme foram constituídos. A destinação caracteriza cada reserva. Se a lei a exige, diz-se reserva legal. As outras são as reservas especiais, estatutárias, extraordinárias (por deliberação da assembléia geral, ou, como ato de prudência e de segurança administrativa, por deliberação da Diretoria), ou ocultas. Todas aumentam, a latere, o patrimônio social líquido" ${ }^{, 3}$.

Comentário muito similar é encontrado na obra do ilustre jurista italiano Tullio Ascarelli, que demonstra origens mais remotas para a regra do art. 1.187 do Código Civil: "Il codice se preoccupa delle valutazioni da compiere in relazione ad uno svolgimento normale degli affari ed all'uopo fissa da un lato i fatti dai quali deve muovere la valutazione e dall'altro i limiti massimi della stessa. Il criterio direttivo è in sostanza, il seguente: nella valutazione del bene, si deve, dato un ovvio criterio prudenziale che trova la sua ragione d'essere nella tutela dei creditori, tener conto delle possibilita di perdita e non tener invece conto delle speranze di utili. Perciò $i$ bene saranno valutati al prezzo di costo o a quello di mercato, a seconda di quale dei due sai inferiore (...) per quelli non destinati alla vendita si dovrà tener conto annualmente (nei confronti del loro costo) della diminuizione di valore dovuta al loro uso o deperimento attraverso l'iscrizione nel passivo di un fondo de ammortamento che sara annualmente incrementato della quota relativa" 94.

Não obstante a autoridade dos dois juristas ilustres citados, uma análise mais aprofundada demonstra que, se o procedimento mencionado (constante do art. 1.187 do Código atual) já teve alguma lógica ou emprego prático no passado, de há muito se encontra superado.

Primeiramente, a regra do art. 1.187 parece impor que se faça a substituição ou a conservação do valor dos bens do imobilizado, quando se trata, na verdade, de uma faculdade da sociedade empresária: poderá esta, ao seu bel-prazer, simplesmente não substituir um determinado bem, nem envidar esforços para conservar seu valor, deixando que o ativo se deteriore com o passar do tempo. A evolução tecnológica, aliás, proporciona, em maior velocidade, simples desaparecimento de bens, que não são repostos por similares: quem criaria, hoje, fundo de amortização para substituição de máquinas de

\footnotetext{
${ }^{93}$ MIRANDA, Pontes de. Op. cit., 1983. t. L, p. 428-9.

94 ASCARELLI, Tullio. Corso de Diritto Commerciale. Introduzione e teoria dell'impresa. Milão: Giufrè, 1962. p. 290.
} 
escrever manuais por modelos mais novos, ou para a conservação de valor de um computador "IBM XT"?

A forma de escrituração preceituada pelo Código Civil também não mais corresponde à realidade, nem mesmo às últimas lições da doutrina contábil.

Nesses termos, vejamos.

Em primeiro lugar, a nomenclatura fundo de amortização já não é apropriada. Iudícibus et al. acentuam que "Eram de uso bastante generalizado os títulos de conta Fundo de Reserva, Fundo de Depreciação, Fundo de Devedores Duvidosos e outros. Autores renomados, porém, condenam o uso da palavra 'fundo', em tais denominações. Em seu entender, a palavra em questão tem o significado de 'dinheiro' ou 'créditos a receber' $e$, portanto, não tem sentido falar-se em fundo no passivo. Smalenbach, um dos mais famosos autores alemães, afirma que a palavra fundo 'tem o inconveniente de induzir a crer que os fundos representam Capital que se encontra em dinheiro ou em outra forma tangível qualquer'. Kester, um dos mais abalizados autores norte-americanos, comenta a respeito das reservas que elas '... às vezes se denominam fundos de reserva, mas se atendermos a uma terminologia adequada, observaremos que o vocábulo fundo somente pode ser aplicado em conta de ativo" 95 .

E como salienta Eliseu Martins, "Chamar as reservas de lucros, do patrimônio, de fundos de reserva, é uma volta a décadas, e, mesmo assim, a uma época que os críticos dessa terminologia já bradavam suas vozes" ${ }^{\text {9 }}$.

Os fundos de reserva parecem corresponder ao que a Lei n. 6.404/76 denomina hoje simplesmente "reservas" (de lucros, de reavaliação ou de capital), fazendo parte do passivo ${ }^{97}$ ou mesmo do patrimônio líquido da sociedade (comumente de uma S/A

\footnotetext{
${ }^{95}$ IUDÍCIBUS, Sérgio de, et al. Contabilidade introdutória. São Paulo: Atlas, 1990. p. 236.

${ }^{96}$ MARTINS, Eliseu. Op. cit., ano 2002, parte 2, p. 1-2.

97 Em algumas obras (na maioria das vezes de autores mais antigos) ainda se encontra esta forma de contabilização da depreciação, qual seja, através de uma conta de passivo integrada no que alguns chamavam de passivo de reintegração ou de reposição, cuja contrapartida se dará em conta de despesa, componente do resultado. Nesse sentido: SÁ, Antônio Lopes de. Planos de Contas. São Paulo: Atlas, 1998.
} 
e não de uma limitada), como pode se verificar do comentário de Pontes de Miranda, acima transcrito.

Tais contas, entretanto, não são destinadas à escrituração da depreciação. De fato, a depreciação corresponde ao reconhecimento de uma despesa pela diminuição de valor que determinado bem sofre pelo decurso do tempo ou obsolescência tecnológica. Sua escrituração envolve basicamente duas contas: uma retificadora do valor do ativo respectivo (p. ex.: depreciação acumulada) e outra de resultado (p. ex.: despesas de depreciação).

Não se tem mais como correta a inclusão da depreciação no passivo (como sugere Ascarelli) ou no patrimônio líquido (como ilustra Pontes de Miranda). Alocar os valores das quotas de depreciação no passivo seria encará-la como uma verdadeira dívida com terceiros, o que não existe. Inseri-la no patrimônio líquido também é incorreto, pois não é matéria própria e adequada para as reservas de qualquer tipo.

Isso tudo sem contar que o registro da depreciação não garante a reposição ou recuperação do valor.

Por tais motivos, concordamos integralmente com as observações de Eliseu Martins, que critica duramente a disposição do Código ${ }^{98}$. Ainda que não se referindo

\footnotetext{
98 "Primeiramente. o texto fala em bens que se desgastam ou depreciam, parecendo terem sido esquecidos os que se exaurem, como as jazidas minerais. as florestas etc. A atual Lei das S/A não comete esse equívoco. Há também o caso dos que simplesmente têm seus benefícios usufruídos, ou têm vida útil econômica limitada por disposições legais, como no caso de tantos intangíveis que são amortizados, apesar de que de alguns deles essa lei fala noutro ponto. O relevante é a volta de uma terminologia não mais usada praticamente em lugar nenhum no mundo mais conhecido: fundo de amortização. Será que vamos voltar a ter as velhas confusões? Fundo de amortização de veículos poderá induzir alguém à crença de que a empresa tenha de fato um fundo para renovar seus automóveis? O Brasil tem se caracterizado, desde a edição da atual Lei das S/A, final de 1976, por ser um país onde raras são as confusões entre Fundo, Provisão e Reserva. Todos os profissionais e todos os usuários das demonstrações contábeis (estes quando com o mínimo conhecimento para entendê-las) sabem o que é um Fundo de Garantia por Tempo de Serviço, uma Provisão para Depreciação ou uma Reserva Legal e não confundem os conceitos. Até a confusão entre Provisão para Contingências e Reserva para Contingências diminuiu enormemente, praticamente quase que desaparecendo de vez no Brasil. A idéia de fundo ligado à existência de dinheiro ou outros ativos facilmente conversíveis em dinheiro para determinada destinação pode causar, de fato, como sempre causou no passado, muita confusão. Ainda mais se acoplada à idéia de substituição ou a conservação do valor do ativo. Com certeza ficará a idéia, incorreta, de que se existe saldo nessa conta, valor igual estará à disposição da empresa para repor o mesmo ativo ou pelo menos para manter o seu valor de hoje. Ora, isso é demonstrar um certo desconhecimento de Contabilidade. Vamos a um exemplo. Imagine uma empresa que tenha receitas $e$ despesas que afetam caixa igualando-se, mantendo seu ativo disponível totalmente nulo ao final do período, mas que, pelo registro da depreciação, venha a ter prejuízo. Aparecerá o fundo de amortização ou de
} 
expressamente ao Código Civil, é apropriada a crítica de Alexandre Assaf Neto, para quem “Essas depreciações, exaustões e amortizações não são contabilmente feitas para criar 'fundos' para a empresa readquirir esses bens, mas para se considerarem esses pedaços do imobilizado como consumidos e jogá-los na apuração do resultado (...) Essas depreciações, amortizações e exaustões são recuperações do passado, e não necessariamente constituição de fundos para a reimobilização. Da mesma forma que o recebimento em devolução do principal que se empresta a terceiros não é receita, também a recuperação do valor originariamente aplicado no imobilizado não é lucro" ${ }^{99}$.

Vejamos a seguir o parágrafo único do art. 1.187, que normatiza a forma de inclusão de alguns valores no ativo, nos seguintes termos:

Parágrafo único. Entre os valores do ativo podem figurar, desde que se preceda, anualmente, à sua amortização:

I - as despesas de instalação da sociedade, até o limite correspondente a dez por cento do capital social;

II - os juros pagos aos acionistas da sociedade anônima, no período antecedente ao início das operações sociais, à taxa não superior a doze por cento ao ano, fixada no estatuto;

depreciação e poderá haver a idéia de que de fato a empresa possui e guardou, para essa finalidade específica de repor seu imobilizado, determinada importância em dinheiro. Concordamos que em alguns países escritores e profissionais às vezes ainda trocam Provisão por Reserva; encontramos alguns maus exemplos disso ainda entre alguns norte-americanos, por exemplo, mas confusão com fundo, não. Ou será então que a lei nova está realmente a obrigar à constituição de fundos verdadeiros? Afinal, releia-se o item I do art. 1.187 e ele diz textualmente: '...criando-se fundos de amortização... .' Teriam as sociedades que depositar num fundo, num banco, o valor relativo às suas depreciações, amortizações e exaustões? É claro que não dá para entender isso. Todavia a continuação desse item fala que esse fundo se destina a 'assegurar-lhes a substituição ou a conservação do valor'! Todos sabemos que a depreciação é a alocação sistemática do custo de aquisição de um bem destinado ao uso e que perde pelo menos parte do seu valor com o tempo, uso etc. Representa, no caso da fabricação de um produto, por exemplo, que o dinheiro gasto para fabricá-lo não é apenas a soma da mão-de-obra com as matérias-primas, materiais outros, aluguel, encargos sociais, energia elétrica e outros itens necessários para se obtê-lo. Há que se incluir também uma parte do dinheiro gasto na compra das máquinas, do edifício e outros itens que também estão ajudando na sua produção. A depreciação, em Contabilidade, sempre foi a alocação de um custo de aquisição aos produtos ou a períodos ou a ambos. $O$ registro da depreciação não garante, absolutamente, a reposição do ativo ou o retorno atualizado do valor nele investido. O que garante o retorno é a receita obtida. Se dela, após deduzidas todas as despesas, inclusive a de depreciação, conseguir-se pelo menos resultado nulo, isso significará que terá sido recuperado um pedaço do valor aplicado no imobilizado que se depreciou, mas esse valor em caixa não significará capacidade para a sua reposição” (MARTINS, Eliseu. Op. cit., ano 2002, parte 2, p. 1-2).

${ }_{99}^{9}$ NETO, Alexandre Assaf. Finanças corporativas e valor. São Paulo: Atlas, 2007. p. 95. 
III - a quantia efetivamente paga a título de aviamento de estabelecimento adquirido pelo empresário ou sociedade.

Primeiramente, saliente-se que o inciso I diz respeito ao que se denomina ativo diferido, referindo-se particularmente às despesas pré-operacionais, matéria já examinada neste trabalho. Deve-se notar que o texto traz uma limitação: só poderão figurar no diferido até $10 \%$ do capital social, sendo que o restante deverá, forçosamente, ser lançado como despesa no resultado. Essa disposição fatalmente tornará inaplicável a inserção de valores no diferido em casos de empreendimentos que demandem grande investimento inicial, antes do início das operações em si.

Não vemos, efetivamente, qualquer razão plausível para a limitação constante do inciso I.

Igual ausência de razão está na limitação do inciso II, que permite a ativação dos juros pagos aos acionistas na fase pré-operacional, mas tão-somente daquilo que não exceder a 12\% ao ano. Veja-se que a Lei n. 6.404/76 (art. 179, V) contém dispositivo semelhante, sem qualquer limitação, não se justificando a divergência de tratamento, justamente quando o Código Civil em outros dispositivos específicos (p. ex. art. 406) não limita a taxa de juros legais. Além disso, o inciso cria, sem qualquer justificativa, uma divergência entre dois diplomas legais.

Por derradeiro, o inciso III parece permitir a contabilização no ativo do valor do ágio, assim considerado como a quantia além do valor de custo dos bens que compõem o estabelecimento comercial adquirido, correspondente ao que se chama na doutrina comercialista de aviamento ou goodwill. Tais valores poderão ser mantidos no ativo, com futura apropriação ao resultado através de amortização.

Sobre o aviamento, encontramos disposição semelhante no art. 2.426 do Código Civil italiano, com algumas distinções referidas à autorização do Conselho de Administração e o prazo de cinco anos (ou excepcionalmente superior) para a amortização: 
“[...] l'avviamento può essere iscritto nell'attivo con il consenso del collegio sindacale, se acquisito a titolo oneroso, nei limiti del costo per esso sostenuto e deve essere ammortizzato entro un periodo di cinque anni. $E^{\prime}$ tuttavia consentito ammortizzare sistematicamente l'avviamento in un periodo limitato di durata superiore, purché esso non superi la durata per l'utilizzazione di questo attivo e ne sia data adeguata motivazione nella nota integrativa $[\ldots] ”$.

Após os artigos sobre a escrituração em si, o Código Civil passa a regrar duas demonstrações contábeis: o balanço patrimonial e o chamado balanço de resultado econômico, nos arts. 1.188 e 1.189. Não trata referido diploma legal de outras demonstrações contábeis, tais como a demonstração de origens e aplicações de recursos (DOAR), a demonstração do fluxo de caixa (DFC), a demonstração de mutações no patrimônio líquido (DMPL) ou de lucros e prejuízos acumulados (DLPA), motivo pelo qual as sociedades limitadas (e as demais reguladas unicamente pelo Código Civil) estarão desobrigadas de elaborá-las.

E, como de hábito, não andou bem novamente o legislador: trocou nomenclaturas, inverteu conceitos e tornou, mais uma vez, inaplicáveis várias passagens dos dispositivos legais.

Vejamos o regramento a seguir, salientando que voltaremos ao assunto mais adiante, quando da análise das demonstrações contábeis:

Art. 1.188. O balanço patrimonial deverá exprimir, com fidelidade e clareza, a situação real da empresa e, atendidas as peculiaridades desta, bem como as disposições das leis especiais, indicará, distintamente, o ativo e o passivo.

Parágrafo único. Lei especial disporá sobre as informações que acompanharão o balanço patrimonial, em caso de sociedades coligadas. 
Art. 1.189. O balanço de resultado econômico, ou demonstração da conta de lucros e perdas, acompanhará o balanço patrimonial e dele constarão crédito e débito, na forma da lei especial.

$\mathrm{O}$ art. 1.188, caput, na verdade, diz o óbvio: indicação de ativo e passivo, expressão de clareza e fidelidade. Talvez seu mérito tenha sido espancar qualquer dúvida do intérprete sobre a matéria, ainda que possivelmente de rara ocorrência.

E dizemos sobre a obviedade do artigo supracitado, uma vez que os conceitos explicitados estão na própria idéia de balanço patrimonial. José Carlos Marion, explicando a origem do termo estudado, traz a seguinte lição: "A palavra balanço decorre do equilíbrio: Ativo - Passivo + PL, ou da igualdade: Aplicações = Origens. Parte-se da idéia de uma balança de dois pratos, onde sempre encontramos a igualdade. Mas em vez de se denominar balança (como balança comercial...) denomina-se balanço. O termo patrimonial tem origem no patrimônio da empresa, ou seja, conjunto de bens, direitos e obrigações. Daí o chamar-se de patrimonial. Juntando ambas as palavras, obtém-se o balanço patrimonial, equilíbrio do patrimônio, igualdade patrimonial. Em sentido amplo, o balanço evidencia a situação patrimonial da empresa em determinada data” ${ }^{100}$.

Os principais problemas se encontram no parágrafo único do art. 1.188 e no art. 1.189 .

O primeiro fala das informações que acompanharão o balanço em caso de coligadas. O segundo fala de "balanço de resultado econômico" e "demonstração da conta de lucros e perdas".

Ao dispor sobre os documentos que deverão acompanhar o balanço, indicando a matéria à regência de lei especial, o art. 1.188, parágrafo único, parece ter-se referido aos casos em que os investimentos na coligada sejam escriturados pelo método da equivalência patrimonial. A verdade, entretanto, é que perde uma grande oportunidade de dizê-lo, determinando quais documentos deverão acompanhar o balanço da sociedade investidora.

${ }^{100}$ MARION, José Carlos. Contabilidade básica. São Paulo: Atlas, 2004. p. 57. 
A menção ao "balanço de resultado econômico", diga-se de passagem, merece críticas veementes. Quis aqui o legislador, na verdade, referir-se ao que se conhece na Lei n. 6.404/76 como demonstração do resultado do exercício. Mas sua nomenclatura evidencia grave erro terminológico, que parece determinar conteúdo diverso do que existe na realidade desta demonstração contábil.

Mais uma vez é inteiramente procedente a crítica do Prof. Eliseu Martins, com a qual concordamos inteiramente ${ }^{101}$.

101 "Novamente os legisladores elou seus auxiliares mostram parecer não entender nem de Contabilidade nem de Economia. Todos nós sabemos que uma das grandes diferenças entre essas duas áreas de conhecimento está no não reconhecimento, ainda, pela primeira, a Contabilidade, de um dos conceitos mais relevantes da segunda: o do Custo de Oportunidade. E ocorre que o Custo de Oportunidade é um dos conceitos mais relevantes dentro da Ciência Econômica em geral, e quando se fala em lucro econômico, obrigatoriamente nele está esse conceito embutido. Na verdade, temos muitos profissionais praticantes da Contabilidade e professores da área reclamando dessa enorme falha da Contabilidade ao longo do tempo, mas acontece que até hoje não foi possível encontrar condições práticas que permitissem a implantação do Custo de Oportunidade na Contabilidade Geral (ou Financeira, como chamada às vezes). Aplicamos esse conceito apenas dentro da Contabilidade Gerencial, mas isso para fins de relatórios internos que não o Balanço e a apuração do Resultado. (A única exceção contábil é a imputação de juros sobre o capital dos acionistas na fase anterior ao início das operações sociais, da qual falaremos ao final deste artigo). Para explicar um pouco mais, vamos relembrar o que é o Custo de Oportunidade. Ele representa o que se obteria com a melhor alternativa desprezada quando se toma uma decisão. Por exemplo, quem está lendo este artigo poderia estar fazendo outra coisa. O beneficio desta leitura tem como custo o que o leitor está deixando de obter ao não fazer a outra coisa. Quem aplica seu dinheiro num fundo de investimento em vez de gastá-lo numa viagem de recreio tem a renda da aplicação, mas arca com o Custo de Oportunidade relativo ao prazer que perdeu por não ter feito sua viagem. No caso de uma empresa, o grande problema da Contabilidade está, no que respeita ao não registro desse Custo, na apuração de um Resultado que contempla toda a despesa representada pelo custo do uso de capital de terceiros (despesas financeiras em geral), mas que não registra o quanto custa o uso do capital dos próprios sócios da empresa. Assim, não é computado, para diminuir o lucro contábil e se chegar, efetivamente, a um lucro mais econômico, o Custo de Oportunidade do patrimônio líquido dos sócios, ou seja, o quanto eles consideram como o que estariam ganhando na melhor alternativa desprezada ao fazerem seu investimento. Em outras palavras, não estamos contabilizando, na apuração do Resultado, o quanto os sócios consideram como o mínimo abaixo do qual não estariam interessados em manter-se como sócios tendo em vista o juro do dinheiro, o risco do negócio e as demais alternativas existentes para eles no mercado (...) A ausência da aceitação e do uso desse conceito pela Contabilidade no mundo inteiro é que levou à criação do Valor Econômico Adicionado (EVA Economic Value Added) por profissionais norte-americanos que acabaram por fazer um enorme furor com sua criação e sua implantação em muitas empresas, mas sempre para fins gerenciais ou de análise, sem mudança contábil propriamente dita (infelizmente). Os autores dessa idéia e dessa sigla nada mais fizeram do que aplicar um dos conceitos mais antigos conhecidos da humanidade, o desse Custo de Oportunidade, mostrando quais as empresas que geram lucro contábil maior do que esse Custo de Oportunidade dos acionistas e quais não (quais as que auferem valor econômico adicionado e quais as que "destroem valor" para a empresa - como conhecido na sua linguagem). O Custo de Oportunidade é um dos conceitos mais antigos do homem, e não tem a ver, na verdade, com o mundo econômico apenas. Os próprios exemplos que utilizamos no início da explanação falavam em leitura versus outra alternativa qualquer do leitor, que poderia ser estar trabalhando em outra coisa, assistindo novela, fazendo ginástica, namorando etc. ou naquele que investia em vez de viajar. O homem é movido por esse conceito em tudo o que faz, o tempo todo. Ao assistir um filme na televisão, arca com o Custo de Oportunidade de ler um livro; ao namorar, o jovem ou a jovem arca com o Custo de Oportunidade de estudar; ao comprar um automóvel, a pessoa arca com o Custo de Oportunidade de aplicar o dinheiro e ganhar juros etc. etc. Costumamos dizer que esse conceito é tão universal que nem privativo do ser humano é. Sempre brincamos com o exemplo do cachorro que, ao 
Resta claro, por essas últimas explicações, que aqui não se trata de balanço (por nem sequer tratar de igualdade patrimonial, mas de contas de resultado), e muito menos de resultado "econômico", já que, não incluindo o custo de oportunidade, cuida-se de resultado puramente contábil.

Talvez o legislador tenha se inspirado do direito italiano, no qual o balanço é subdividido em duas demonstrações: o estado patrimonial (stato patrimoniale, correspondendo ao conceito de balanço propriamente dito) e a conta econômica (conto economico, correspondendo à demonstração de resultados) ${ }^{102}$.

estar comendo e ver um gato, sabe que, se sair correndo atrás dele, estará arcando com o Custo de Oportunidade de perder ou adiar a comida. Fatores como outro cão que poderá comer sua comida, com quanta fome está, quanta raiva possui de gatos ou daquele especialmente etc. irão determinar o tamanho do benefício e o do tal Custo, e daí tomará sua decisão. O Custo de Oportunidade é, na verdade, conceito de todo o ser vivo que toma decisões. Mas, infelizmente, não é ainda aceito na Contabilidade (com aquela exceção mencionada a ser referida ao final). E não o é porque o grande problema está na sua mensuração, e não no seu conceito teórico. Cada investidor tem o seu próprio Custo de Oportunidade, dependendo do seu nível de aversão ao risco, das oportunidades que tem, de sua ambição etc. Para cada empresa esse custo seria o da média ponderada dos diversos sócios, e isso inclusive muda com o tempo e com outras condições. $O$ mercado financeiro se utiliza de determinadas técnicas estatísticas e de dados referentes ao comportamento dos investidores em ações para calcular o Custo de Oportunidade de cada empresa em cada momento. Mas são sempre cálculos muito aproximados e cheios de problemas. São utilizados por diversos profissionais, pesquisadores, revistas técnicas etc., mas sempre com base em algumas hipóteses assumidas, que nada mais são do que aproximações da realidade. É interessante notar que a figura dos Juros Sobre Capital Pr6prio criados pela legislação fiscal está inicialmente baseada nesse conceito, mas nem ela nunca o chamou de Custo de Oportunidade e também jamais denominou de lucro econômico ao lucro contábil após a dedução de tais Juros. Afinal, o conceito fiscal não é o de Custo de Oportunidade para valer, porque baseado na TJLP, que é uma Taxa de Juros de Longo Prazo das dívidas dessa natureza do Tesouro Nacional, nada tendo a ver com o Custo de Oportunidade dos proprietários das empresas. E, na verdade, como já explicamos neste mesmo Caderno em artigos publicados há alguns anos, derivou a adoção dessa idéia pelo Fisco muito mais da cessação da correção monetária do patrimônio liquido do que de qualquer outra. O que interessa, para não nos alongarmos mais exageradamente do que já fizemos, é que resultado econômico não é o nosso resultado contábil, e a adoção dessa nomenclatura nos colocará até em situação ridícula. Dizer que os autores estavam realmente pensando no maior avanço da Contabilidade talvez já dado nos últimos tempos para levar o resultado contábil ao econômico seria forjar uma explicação, porque tantas coisas absurdas estão nessa Lei nessa parte contábil (como já mostrado no caso do técnico em Ciências Contábeis), que não dá para ninguém acreditar nessa eventual saída honrosa que seria justificar como avanço que nós, pobres mortais, não estamos conseguindo avaliar. É claro que há bastante de econômico na nossa Demonstração do Resultado, já que o Regime de Competência tem essa extraordinária característica e capacidade de vincular despesas às receitas, fazendo uma transposição temporal dos fluxos de caixa. Mas não é uma apuração integral de resultado econômico, daí o que consideramos uma terminologia inapropriada e incorreta. Tanto que essa expressão há décadas e décadas não aparece mais na terminologia mais reconhecida do mundo inteiro. E o que falar então do uso da palavra balanço para denominar a demonstração da apuração do resultado de balanço de resultado econômico. Interessante, não? Talvez uma volta há muitas e muitas décadas atrás à procura de alguns que propuseram terminologia parecida com essa mas que, obviamente, nunca foi utilizada”. (MARTINS, Eliseu. Op. cit., ano 2002, parte 2, p. 1-2).

102 Assim disciplina o art. 2.423 do Código Civil italiano: "Redazione del bilancio. Gli amministratori devono redigere il bilancio di esercizio, costituito dallo stato patrimoniale dal conto economico e dalla nota integrativa". 
Outra menção inviável do legislador é que constem crédito e débito dos demonstrativos referidos no art. 1.188. Apesar de a menção mais se aplicar à "conta de lucros e perdas", não ficou excluída a expressão dos débitos e créditos no "balanço de resultado econômico". Ora, esta última demonstração traz as contas de resultado em forma escalonada e classificada (p. ex.: resultado com mercadorias, lucro bruto, lucro operacional, lucro não operacional, lucro antes de impostos, despesas operacionais, lucro líquido, etc.) por seu valor final de encerramento, não indicando lançamentos a débito ou a crédito. Estes (débito e crédito) são feitos quando os valores são lançados nas contas, não quando os valores destas são transportados às demonstrações contábeis.

O registro mais infeliz do legislador, entretanto, foi o referente à "conta de lucros e perdas", retornando, mais uma vez, ao que se tinha décadas atrás, quando da vigência do Decreto-Lei n. 2.627/40.

Para aprimorar seu conceito, recorreremos novamente aos ensinamentos de Pontes de Miranda: “Chama-se, no art. 136 do Decreto-Lei $n$. 2.627, 'conta de lucros $e$ perdas' a exposição do ativo e do passivo da empresa, para que se saiba o que foi que lucrou e o que foi que perdeu (despendeu, ou foi destruído ou deteriorado). Tem-se de atender ao que era saldo devedor, ou credor, vindo do exercício anterior. O primeiro elemento a que o art. 136 se refere é o saldo não distribuído dos lucros anteriores. Se o saldo era devedor, lança-se no passivo (a débito, diz a lei). O segundo elemento positivo consiste nas operações sociais que se concluíram no exercício balanceado, operações que hão de ser discriminadas conforme as fontes ou atividades afins. A débito, são postas as despesas gerais. Se há rendas de capitais não empregados nas operações da empresa, figuram à parte, como terceiro elemento. Após isso, vêm os lucros que não se podem incluir nas operações sociais, nem como rendas de capital não empregadas nas operações sociais. Finalmente, há de constar o saldo que há de ser transportado para o exercício social seguinte. A débito, ficam insertos os importes dos impostos, dos juros pagos a terceiros, ou de despesas com prazo de mora, ou de pena convencional, das amortizações do ativo, das perdas diversas, das reservas e fundos especiais, dos dividendos que têm de ser distribuídos, das remunerações e bonificações a serem pagas aos diretores e, 
finalmente, o do saldo disponível para o exercício seguinte. Também aí se incluem as quantias despendidas em correção monetária" ${ }^{103}$.

Eliseu Martins dá o seguinte exemplo do modelo da época em que era comum a elaboração da conta lucros e perdas:

Quadro 6: demonstração da conta lucros e perdas (cf. Eliseu Martins)

\begin{tabular}{|lr|lr|}
\hline \multicolumn{4}{|c|}{ Demonstração da conta de Lucros e Perdas } \\
\cline { 1 - 2 } Débitos & \multicolumn{1}{c|}{ Créditos } \\
\hline Despesas Comerciais & 200.000 & Saldo do Ano Anterior & 20.000 \\
Despesas Administrativas & 300.000 & Produto das Operações Sociais & 650.000 \\
Despesas financeiras & 50.000 & Reversão Fundo Dev. Duvid. & 3.000 \\
Fundo Devedores & 12.000 & & \\
Duvidosos & 25.000 & & \\
Fundo de Depreciação & 3.300 & & \\
Destinação do Saldo: & 9.900 & & \\
Fundo de Reserva Legal & 15.675 & & $\mathbf{6 7 3 . 0 0 0}$ \\
Reservas Estatutárias & 57.125 & & \\
Dividendos & & & \\
Saldo Final & $\mathbf{6 7 3 . 0 0 0}$ & & \\
& & & \\
& & & \\
\end{tabular}

O autor ressalva a grande dificuldade que qualquer destinatário da escrituração teria em visualizar o lucro do período, simplesmente olhando a demonstração acima transcrita, ao contrário do que ocorre com as demonstrações contábeis ordinariamente praticadas nos dias de hoje, que substituíram a conta de lucros e perdas (demonstração de resultado do exercício e de lucros e prejuízos acumulados).

Reitera ainda que, "Para se saber o lucro líquido, nesse caso, precisava-se somar o Produto das Operações Sociais com a reversão do Fundo de Devedores Duvidosos e dessa soma diminuir-se as despesas, dando, no caso, R\$66.000.00. Mas esse número não é visível, de forma alguma, rapidamente. É preciso não só olhar e ler, mas também ficar fazendo contas. Desse saldo de $R \$ 66.000,00$, são tirados $R \$ 13.200,00$ para Reservas, $R \$ 15.675,00$ para dividendos, e a sobra, $R \$ 37.125,00$, somada ao saldo inicial

${ }^{103}$ MIRANDA, Pontes de. Op. cit., t. L, p. 454. 
de $R \$$ 20.000,00, explica o saldo final de Lucros e Perdas de $R \$$ 57.125,00. E a demonstração está simples, não havendo Provisão para Imposto de Renda. Impostos Diferidos etc. Que diferença quanto ao nosso modelo atual, na forma dedutiva, que tem como único "mal" o fato de que todos são capazes de entendê-la (...) Claro que estamos exagerando ao mostrar esse exemplo da Demonstração da conta de lucros e perdas, exibindo um exemplo sem o valor das Vendas, mas só para lembrar o que fazíamos no passado (e que não podemos tomar como bom exemplo hoje). De qualquer forma, se há uma conta de Lucros e Perdas, ela sempre foi essa mistura de Resultado e de Resultados Acumulados. Uma confusão. Essa demonstração na forma de débitos e créditos parece feita, é óbvio,. só para os contabilistas. Só que o mais importante é que nossas demonstrações sejam entendidas pelos nossos usuários, não tão técnicos e nem tão preparados e especializados. Quanto mais dificultamos seu entendimento, mais os teremos longe de nós e do nosso produto, que são nossas informações"

A elaboração do demonstrativo da conta lucros e perdas, nos termos elencados pelo Código Civil, e para o bem de todos que tenham de trabalhar com essa legislação, parece não ser obrigatória, podendo ser substituída pela demonstração de resultado do exercício (ou "balanço de resultado econômico", como quer a lei). Com efeito, o art. 1.189 ressalta claramente que "O balanço de resultado econômico, ou demonstração da conta de lucros e perdas..." (grifos nossos).

Diante do que até aqui se explanou e da possibilidade de substituição acima aludida, o demonstrativo de lucros e perdas será certamente letra morta.

Não obstante as críticas, a legislação brasileira não é a única que prevê ainda essa antiga forma contábil, a qual consta também do art. 2.217 do Código Civil Italiano, que assim dispõe: “...L'inventario si chiude con il bilancio e con il conto dei profitti e delle perdite, il quale deve dimostrare con evidenza e verità gli utili conseguitio le perdite subite..."

\footnotetext{
${ }^{104}$ MARTINS, Eliseu. Op. cit., ano 2002, parte 1, p. 4.
} 


\subsection{A escrituração das sociedades anônimas como modelo para as sociedades limitadas: aplicação subsidiária da legislação do \\ anonimato}

A sociedade anônima deve possuir, além da escrituração determinada para qualquer comerciante (livros obrigatórios, etc.), outros estipulados pela própria Lei n. 6.404/76 (art. 100 e seguintes).

Assim, é pacífico que as determinações relativas à escrituração aplicáveis a todos os empresários (inseridas no Código Civil e outros diplomas) também se aplicam à sociedade anônima.

Cumpre agora analisar se as normas inseridas na Lei n. 6.404/76, destinadas às sociedades anônimas, são aplicáveis subsidiariamente às sociedades limitadas, quando omisso o Código Civil em questões relativas à escrituração.

Essa aplicação subsidiária, ou até mesmo substitutiva ${ }^{105}$, pode em muito auxiliar o intérprete e servir de solução para os diversos problemas de escrituração constantes do Novo Código Civil (Lei n. 10.406/02), já vistos anteriormente.

Em relação às sociedades limitadas de grande porte ${ }^{106}$, a aplicação da Lei n. 6.404/07 no que tange à parte contábil e escritural é hoje expressamente determinada, diante da redação do art. $3^{\circ}$ da Lei n. $11.638 / 07^{107}$.

\footnotetext{
${ }^{105}$ Defendemos a aplicação substitutiva da Lei n. 6.404/07, com a redação que lhe deu recentemente a Lei 11.638/07, para os casos em que seja inviável ou temerária a aplicação do Código Civil em sua parte referente à escrituração. Exemplo disso é o lançamento de fundos de amortização para bens depreciados. ${ }^{106}$ Toma-se a definição do art. $3^{\circ}$, parágrafo único, da Lei n. 11.638/07, segundo a qual: "Considera-se de grande porte, para os fins exclusivos desta Lei, a sociedade ou conjunto de sociedades sob controle comum que tiver, no exercício social anterior, ativo total superior a $R \$ 240.000 .000,00$ (duzentos e quarenta milhões de reais) ou receita bruta anual superior a $R \$ 300.000 .000,00$ (trezentos milhões de reais)".

${ }^{107}$ Aplicam-se às sociedades de grande porte, ainda que não constituídas sob a forma de sociedades por aç̃oes, as disposições da Lei $n^{\circ}$ 6.404, de 15 de dezembro de 1976, sobre escrituração e elaboração de demonstrações financeiras e a obrigatoriedade de auditoria independente por auditor registrado na Comissão de Valores Mobiliários" (grifos nossos).
} 
Resta discutir agora a aplicabilidade da Lei n. 6.404/76 às limitadas que não sejam consideradas legalmente como de grande porte.

O ponto de partida dessa análise será o disposto no art. 1.053 do Código Civil, que preceitua:

Art. 1.053. A sociedade limitada rege-se, nas omissões deste Capítulo, pelas normas da sociedade simples.

Parágrafo único. O contrato social poderá prever a regência supletiva da sociedade limitada pelas normas da sociedade anônima.

A primeira conclusão que advém da análise do artigo supracitado é que existem duas fontes subsidiárias às normas inseridas no capítulo referente às sociedades por cotas de responsabilidade limitada: 1) as normas referentes às sociedades simples, que se aplicam havendo ou não o assentimento dos sócios formalizado no contrato social; 2) as normas das sociedades anônimas, constantes da Lei n. 6.404/76, que somente seriam aplicáveis com previsão contratual expressa.

A questão a ser respondida é se referido artigo é aplicável em termos de escrituração. Por outras palavras: os processos de escrituração nas sociedades limitadas deverão ter por base a lei das sociedades anônimas somente quando houver previsão contratual, ou a Lei n. 6.404/76 será sempre fonte subsidiária, aplicável a tais situações quando e no que couber?

A resposta requer um exame mais minucioso.

O primeiro ponto a ser verificado é uma impossibilidade de natureza prática de aplicação do art. 1.053, caput supracitado. Isso porque o capítulo referente às sociedades simples praticamente não tem nenhuma referência a normas de escrituração, razão pela qual sua aplicação subsidiária fica praticamente esvaziada ${ }^{108}$.

${ }^{108}$ Dissemos "praticamente" pelo fato de que algumas normas do capítulo referente às sociedades simples no Código Civil tangenciam, passando muito ao largo, o assunto de escrituração. Exemplos disso são os arts. 1.009 e $1.031, \S 1^{\circ}$. 
Note-se também que o art. 1.053 não está inserido no capítulo referente à escrituração, tratando apenas da matéria estritamente societária, inerente à formação, desenvolvimento e extinção das limitadas. A "omissão" a que se refere sobredito artigo, portanto, não é em matéria escritural, mas na matéria tratada no Capítulo IV do Título II do Código Civil.

Logo, as omissões referentes à escrituração não devem ser remetidas puramente às normas das sociedades simples.

Além disso, devemos notar, principalmente no que toca à aplicação do art. 1.053, parágrafo único, que a escrituração não é matéria que se submeta à vontade das partes (no caso os sócios), até porque não somente a elas se destina a atividade escritural, mas também aos credores, ao fisco, aos investidores e a terceiros.

Diante disso, não podem os sócios de uma sociedade por cotas de responsabilidade limitada determinar contratualmente quais serão as normas de escrituração a que se submeterão, excluindo, por ato de vontade própria, a aplicação da Lei das Sociedades Anônimas.

Portanto, deve-se entender que o art. 1.053 e seu parágrafo único do Código Civil não se aplicam no que tange à matéria de escrituração.

Fixada a inaplicabilidade do dispositivo mencionado, é mister que se aprofunde ainda a análise para determinar se há a aplicabilidade subsidiária obrigatória da Lei n. 6.404/76.

Entendemos que a resposta deve ser parcialmente positiva.

A Lei das sociedades anônimas estabelece um verdadeiro diploma de escrituração, contendo grande parte dos princípios e postulados da ciência contábil, que dá suporte aos processos escriturais. 
Há exemplos disso em várias passagens da Lei n. 6.404/76, entre elas o art. 175 (que define a duração do exercício social), o art. 176 (que explicita as demonstrações financeiras), o art. 178 (que disciplina o agrupamento das contas), e outros mais.

As normas da Lei n. 6.404/76, portanto, devem servir de parâmetro de boas práticas contábeis e padrão geral comparativo para a escrituração das sociedades limitadas.

No entanto, há regras insertas na Lei n. 6.404/76 claramente inaplicáveis às sociedades limitadas. Alguns exemplos disso são as normas referentes à escrituração de valores mobiliários como debêntures (art. 182, § 1", "b" e "c"), fixação de reservas obrigatórias (art. 193 e seguintes) e demonstrações financeiras não aplicáveis às limitadas em qualquer caso (como a demonstração de origens e aplicações de recursos, demonstração de lucros acumulados ou mutações no patrimônio líquido).

Mais dois argumentos podem ser adicionados para chegarmos à conclusão da aplicabilidade parcial e subsidiária da Lei n. 6.404/76 às limitadas no que diz respeito à escrituração.

O primeiro, já de natureza histórica, revela que a subsidiariedade da Lei n. 6.404/76 fora a concepção genuína do legislador. Nesse sentido, o Decreto n. 3.078/19, que regulava as sociedades por cotas de responsabilidade limitada, era claro ao expressar, em seu art. 18, que nas omissões do estatuto (e no tema referente à escrituração necessariamente ele seria omisso) dever-se-ia aplicar a Lei das Sociedades Anônimas, naquilo que coubesse.

Essa subsidiariedade, embora de forma parcial, era adotada no antigo diploma falimentar (Dec.-Lei n. 7.661/45), cujo art. 159, § 2º determinava a aplicação expressa da Lei n. 6.404/76 às demonstrações financeiras a serem apresentadas em concordata, qualquer que fosse o tipo societário, nos seguintes termos:

$\S 2^{\circ}$ Às demonstrações financeiras especialmente levantadas para instruir o pedido aplicam-se, ainda, os preceitos dos $\$ \$ 2^{\circ}, 4^{\circ}$ e $5^{\circ}$ do art. 176 e os dos arts. 189 a 200 da Lei n. 6.404, de 15 de dezembro de 1976, independentemente da forma societária do devedor. 
O segundo argumento envolve a aplicação da analogia. De fato, se seguirmos parte da doutrina que equipara as limitadas às sociedades de capital, em que vigora a livre circulação das parcelas de capital titularizadas pelos sócios ${ }^{109}$, teremos um ótimo argumento para a aplicação da analogia em eventual lacuna do Código Civil. Sendo também a sociedade anônima uma sociedade de capital, haverá um mesmo substrato sobre o qual devem incidir as mesmas regras na medida em que forem aplicáveis, pois onde está idêntico fundamento deve ser aplicada a mesma regra jurídica: "ubi eadem ratio ibi eadem iuris dispositio".

\subsection{A Escrituração nas microempresas e empresas de pequeno}

porte

O tratamento privilegiado do microempresário decorre diretamente do texto constitucional, quando este preceitua, no art. 170, XI, ser princípio da ordem econômica o

\footnotetext{
${ }^{109}$ Há intensa divergência doutrinária e jurisprudencial quanto à natureza jurídica das sociedades limitadas. Tal discussão se reflete longamente no RECURSO ESPECIAL No 39.609-3 - SP (Registro no 93.0028291-3). Relator: Ministro Sálvio de Figueiredo, que transcrevemos parcialmente: "Destarte, a sociedade por quotas de responsabilidade limitada é um tipo societário particular 'vis a vis', tal a classificação, sociedade de pessoas e sociedade de capitais. Nelas, às vezes, aproximando-se das sociedades de pessoas, prevalecerá a "affectio". Outras vezes, prevalecerá a intenção capitalística. Elemento indicativo (não o único) é a cessibilidade das quotas sem a anuência dos demais sócios àquele cedente. Por exemplo, e aí até foi imposição legal, como no caso das sociedades anônimas transformadas em sociedades por quotas segundo a previsão do artigo 298 da Lei 6.404/76, em que as quotas são livremente transferidas (inc. II). Outro elemento poderia ser o emprego de denominação, para as sociedades por cotas com sentido capitalístico, ou de firma ou razão social, para aquelas constituídas intuitu personae, como nome comercial (Egberto Lacerda Teixeira, "Das Sociedades por Quotas no Direito Brasileiro", págs. 55 e 56), não devendo tal elemento ser visto isoladamente. Estabelecida a caracterização como sociedade de capital, o que deve ser feito caso a caso, cederá a restrição à penhora das quotas. E tal caso, já que a intenção, o animus, não sendo pessoal, é capitalístico, não haverá o obstáculo apontado. Porém, nas sociedades de pessoas o óbice permanece. Segundo a jurisprudência: 'Sociedade comercial - Responsabilidade limitada - Penhora de cotas sociais por débito de cotistas para com terceiros - Viabilidade atrelada à natureza da sociedade Admissibilidade se de capital e estabelecida a livre cessibilidade, cedendo a affectio societatis Inadmissibilidade em tese se de pessoa, supondo anuência dos demais sócios à cessão de cotas. Ementa oficial: Sociedade por quotas de responsabilidade limitada. Penhora de quotas sociais por débito de quotistas para com terceiros. Possibilidade ou impossibilidade, segundo a doutrina e a jurisprudência, indexada à natureza da sociedade. Se sociedade de capital e estabelecida a livre cessibilidade, cede a affectio societatis e cabe a penhora. Se a cessão das quotas supõe a anuência dos demais sócios, há sociedade de pessoas e, em tese, a quota é impenhorável. Ap. 190013219 - Erexim - $4^{a}$ Câm. Civil do TARS Apte.: Prorec - Processamento, Representações e Assessoria Contábil Ltda. - Apdo.: Banco Meridional do Brasil S/A - v.u. - j. 29.3 .90 - Rel. Juiz Sérgio Muller' (RT 655/172)”.
} 
tratamento favorecido para as empresas de pequeno porte constituídas sob as leis brasileiras e que tenham sua sede e administração no País.

Certamente, um dos tratamentos a serem dados às empresas de pequeno porte é o referente à escrituração empresarial, que não pode ter idêntico grau de complexidade àquele obrigatório às grandes sociedades empresárias.

A definição do que seja pequena empresa, microempresa ou empresa de pequeno porte foi deixada pelo constituinte para a legislação ordinária.

Dizia o art. $1^{\circ}$ do Decreto n. 64.567/1969:

Art. $1^{\circ}$ Considera-se pequeno comerciante, para os efeitos do parágrafo único do art. $1^{o}$ do Decreto-lei n. 486, de 3 de março de 1969, a pessoa natural inscrita no registro do comércio:

I - Que exercer em um só estabelecimento atividade artesanal ou outra atividade em que predomine o seu próprio trabalho ou de pessoas da família, respeitados os limites estabelecidos no inciso seguinte;

II - Que auferir receita bruta anual não superior a cem (100) vezes o maior salário mínimo mensal vigente no país e cujo capital efetivamente empregado no negócio não ultrapassar vinte (20) vezes o valor daquele salário mínimo.

Apesar da definição supracitada, a legislação posterior veio a tratar da microempresa, tendo como base somente seu faturamento ou receita bruta.

Ainda antes da Constituição Federal de 1988, foi regulada a dispensa, para as micro e pequenas empresas, da escrituração de livros contábeis pela Lei n. 7.256/84. Referida lei, em seu artigo 15, dispunha que: 
Art. 15 - A microempresa está dispensada de escrituração (Vetado), ficando obrigada a manter arquivada a documentação relativa aos atos negociais que praticar ou em que intervier.

Houve alguma divergência quanto à abrangência de referida dispensa de escrituração, sendo que alguns a consideraram como incidente somente sobre os livros fiscais e não sobre os determinados pela legislação comercial.

No entanto, o Supremo Tribunal Federal decidiu especificamente a matéria, sendo importante citar trecho do voto do Ministro Celso de Mello no HC 72691/RS, julgado em 29/08/1995 e publicado no DJ 06-10-1995:

"O Tribunal ora apontado como coator, respondendo afirmativamente a essa indagação, entendeu que a constituição de uma microempresa não tem, por si só, o condão de exonerar os réus administradores, tratando-se da hipótese prevista no art. 186, VI, da legislação falimentar, da responsabilidade penal emergente da inobservância da obrigação genericamente imposta a todos os comerciantes, notadamente porque a Lei n. 7.256/84, ao instituir o Estatuto da Microempresa, tê-la-ia dispensado, tão-somente, do dever de possuir escrituração meramente fiscal.

Tenho para mim, no entanto, que, com a superveniência do Estatuto da Microempresa (Lei n. 7.256/84), e até o advento da Lei n. 8.864, de 28/3/94, operou-se, nessa específica matéria - e no que concerne ao microempresário -, uma inquestionável descaracterização típica do comportamento delituoso previsto, para os comerciantes em geral, pelo art. 186, $V$ da legislação falimentar, de tal modo que a irregularidade em sua escrituração contábil despojou-se, tratando-se de microempresário, de qualquer expressão penalmente relevante.

Com a edição da Lei $n$. 7.256, de 27/11/84, objetivou-se a fixação de tratamento normativo peculiar à microempresa, tratamento este vocacionado a assegurar-lhe regime diferenciado, simplificado $e$ 
favorecido nos campos administrativo, tributário, previdenciário, trabalhista, creditício e de desenvolvimento empresarial.

A norma inscrita no art. 15 desse estatuto legal, coerente com a necessidade de conferir tratamento diferenciado, simplificado e favorecido à microempresa, excluiu-a do regime ordinário aplicável às demais empresas mercantis, exonerando-a do dever de possuir escrituração contábil.

O preceito legal em questão dispõe que 'A microempresa está dispensada de escrituração, ficando obrigada a manter arquivada a documentação relativa aos atos negociais que praticar ou em que intervier' (fls. 6).

Convém ressaltar, neste ponto, que o Presidente da República, em veto governamental mantido pelo Congresso Nacional, excluiu da norma legal referida a cláusula que, presente, justificaria o entendimento restritivo consagrado pelo tribunal ora apontado como coator.

Com efeito, o texto aprovado pelo Congresso Nacional limitava o favor legal em questão apenas à escrituração fiscal, impedindo, desse modo, que o benefício em causa se estendesse também à escrituração mercantil.

O Chefe do Poder Executivo da União, no entanto, ao vetar a expressão 'fiscal', assim justificou as razões que o levaram a impedir a restrição que se mostrava incompatível com os propósitos teleológicos visados pelo Poder Público na definição do regime jurídico diferenciado aplicável às microempresas, verbis:

'Objetiva, ainda, o projeto reduzir ao mínimo as exigências burocráticas a que se submetem as microempresas. Contraria, portanto seu escopo, a limitação ao dispositivo que as libera da obrigatoriedade da escrituração. Conseqüentemente, resolvi vetar, por contrária ao interesse público, á expressão 'fiscal' constante do artigo 15.' (grifei)" 
A isenção acima mencionada durou até a sobrevinda da Lei n. 8.864/94, que não previu dispensa de escrituração, ressaltando apenas que esta seria simplificada (art. 11). Confirmando a necessidade de escrituração do micro e pequeno empresário, por nada excepcionar ao regime geral de obrigatoriedade de escrituração, a Lei n. 9.841/99 não dispôs sobre qualquer dispensa.

O novo Código Civil, retornando ao sistema anterior que estabelecia a inexigibilidade de escrituração, estabeleceu os seguintes artigos referentes ao assunto:

Art. 970. A lei assegurará tratamento favorecido, diferenciado e simplificado ao empresário rural e ao pequeno empresário, quanto à inscrição e aos efeitos daí decorrentes.

Art. 1.179. O empresário e a sociedade empresária são obrigados a seguir um sistema de contabilidade, mecanizado ou não, com base na escrituração uniforme de seus livros, em correspondência com a documentação respectiva, e a levantar anualmente o balanço patrimonial e o de resultado econômico.

$\S 1^{o}$ Salvo o disposto no art. 1.180, o número e a espécie de livros ficam a critério dos interessados.

$\S 2^{\circ}$ É dispensado das exigências deste artigo o pequeno empresário a que se refere o art. 970.

A primeira constatação a se fazer aqui, conquanto possa parecer óbvia, é que as regras ora mencionadas se aplicam tanto ao empresário individual (exercício individual da empresa) quando à sociedade empresária de pequeno porte (exercício coletivo da empresa).

Da leitura dos dispositivos supracitados, podemos tirar as seguintes conclusões: 1) não há definição de pequeno empresário no Código Civil, ficando a cargo da legislação específica; 2) por não definir seus conceitos, o Código Civil remete a outro 
diploma legislativo o tratamento diferenciado dos pequenos empresários quanto a sua inscrição e respectivos efeitos; 2) fica dispensado o pequeno empresário definido no art. 970 da manutenção de um sistema de contabilidade (caput), bem como do disposto no art. 1.180 (escrituração do livro Diário).

A dispensa da escrituração do livro Diário, entretanto, ainda sofre algumas divergências na doutrina.

De fato, em estudos interpretativos do novo Código Civil, as Jornadas de Direito Civil do Superior Tribunal de Justiça, na comissão referente ao Direito de Empresa $^{110}$, restou fixado o entendimento de número 56, a seguir transcrito:

56 - Art. 970: O Código Civil não definiu o conceito de pequeno empresário; a lei que o definir deverá exigir a adoção do livro diário.

Posteriormente, na III Jornada, foi fixado entendimento diverso, consentâneo com aquele aqui defendido (definição na Lei n. 9.841/99, dispensando-se o Diário) e elaborando-se o enunciado número 235 :

235 - Art. 1.179: O pequeno empresário, dispensado da escrituração, é aquele previsto na Lei n. 9.841/99. Fica cancelado o Enunciado n. 56.

Aliás, esse último entendimento já fora esposado pelo Prof. Haroldo Malheiros Duclerc Verçosa: "Quanto ao pequeno empresário, fica dispensado das exigências de escrituração previstas no art. 1.170 do NCC (...). No entanto, o alcance dessa dispensa não ficou claro, na medida em que a obrigatoriedade do 'Diário' está prevista no art. 1.180, em relação ao qual tal favor legal não estaria abrangido. Mas esta seria uma interpretação contraditória. Se o pequeno comerciante não está obrigado a seguir um sistema de contabilidade, então, não haveria motivo para estar sujeito à utilização de um livro voltado para tal finalidade"111.

\footnotetext{
${ }^{110}$ Referidos estudos foram efetivados em comissão presidida por Alfredo de Assis Gonçalves Neto e tiveram como relatores Newton de Lucca e Jorge Luiz Lopes do Canto.

${ }^{111}$ VERÇOSA, Haroldo Malheiros Duclerc. Curso de Direito Comercial. São Paulo: Malheiros, 2004, v. 1, p. 188 .
} 
Segue-se aqui, portanto, o entendimento da dispensa, em relação ao pequeno empresário (microempresário ou empresário de pequeno porte), da escrituração comercial.

As coisas pareceriam pacificadas até o presente momento, não fosse a necessidade de conjugação do Código Civil com a Lei n. 9.317, de 5 de dezembro de 1996 (hoje revogada pela Lei Complementar n. 123/06), já referida no presente trabalho, que dispunha sobre o regime tributário das microempresas e das empresas de pequeno porte e instituía o sistema integrado de pagamento de impostos e contribuições das microempresas e das empresas de pequeno porte - SIMPLES.

Referida lei, em seu art. $7^{\circ}$ e parágrafos, estabelecia que:

Art. $7^{o}$ A microempresa e a empresa de pequeno porte, inscritas no SIMPLES apresentarão, anualmente, declaração simplificada que será entregue até o último dia útil do mês de maio do ano-calendário subseqüente ao da ocorrência dos fatos geradores dos impostos $e$ contribuições de que tratam os arts. $3^{\circ}$ e $4^{o}$.

$\S 1^{\circ}$ A microempresa e a empresa de pequeno porte ficam dispensadas de escrituração comercial desde que mantenham, em boa ordem e guarda e enquanto não decorrido o prazo decadencial e não prescritas eventuais ações que lhes sejam pertinentes:

a) Livro Caixa, no qual deverá estar escriturada toda a sua movimentação financeira, inclusive bancária;

b) Livro de Registro de Inventário, no qual deverão constar registrados os estoques existentes no término de cada ano-calendário;

c) todos os documentos e demais papéis que serviram de base para a escrituração dos livros referidos nas alíneas anteriores. 
Assim, restaria saber se o Código Civil teria revogado a legislação das microempresas e empresas de pequeno porte em relação à escrituração, ou se permaneceria a obrigação de escriturar nos termos da Lei n. 9.317/96, na época em que referida lei esteve em vigor, tendo a microempresa e a empresa de pequeno porte que escriturar os livros Caixa e Registro de Inventário.

Sobre o tema, Fábio Ulhoa Coelho ensina que: "Como o Código Civil é norma geral e não revoga as normas especiais, deve-se considerar que o microempresário e o empresário de pequeno porte inscritos no Simples não podem beneficiar-se da dispensa de escrituração do art. $1.179, \S 2^{\circ}$, do CC ${ }^{\prime 112}$.

Em outra obra, referido autor salienta: "Em suma, devem-se distinguir, hoje, três situações. Se o microempresário ou empresário de pequeno porte não é optante pelo SIMPLES, ele atende aos requisitos legais de dispensa do dever geral de escrituração, estando, por isso, desobrigado de escriturar qualquer livro. Se é microempresário ou empresário de pequeno porte optante pelo SIMPLES, está obrigado a escriturar os livros Caixa e Registro de Inventário, já que o Código Civil de 2002, por ser norma geral, não revogou a Lei 9.317/96, diploma especial. Nas demais hipóteses, o empresário está obrigado a escriturar o Diário" ${ }^{\prime 13}$.

Concordamos, à época da vigência da Lei n. 9.317/96, apenas parcialmente com a explanação deste último doutrinador.

Primeiramente, deveremos fazer novamente a distinção entre escrituração comercial e fiscal.

A Lei n. 9.317/96 regulava a escrituração visando unicamente a finalidades arrecadatórias de impostos, criando, na verdade, uma obrigação acessória tributária. Cuidase em referida lei apenas de livros fiscais e não comerciais.

${ }^{112}$ COELHO, Fábio Ulhoa. Código... cit., 2003, p. 1159.

${ }^{113}$ COELHO, Fábio Ulhoa. Curso de Direito Comercial. São Paulo: Saraiva, 2003. p. 83. 
Diante disso, optante ou não em relação ao SIMPLES, o microempresário ou empresário de pequeno porte não estará obrigado a qualquer escrituração de natureza comercial, por força da dispensa do art. $1.179, \S 2^{\circ}$, do Código Civil.

Diferentemente será sua situação em relação aos deveres tributários acessórios, de ordem escritural.

Com efeito, com relação a estes, duas situações eram possíveis à época de vigência da Lei n. 9.317/96: 1) o microempresário ou empresário de pequeno porte faz opção por ser tributado no sistema SIMPLES; 2) referido empresário não efetiva opção por ser tributado no sistema SIMPLES.

No primeiro caso, concordamos com a conclusão supracitada, devendo ele escriturar os livros Caixa e Registro de Inventário, com a ressalva de se tratar, aqui, de escrita fiscal e não comercial.

Na segunda hipótese, somos obrigados a divergir. Se o microempresário ou empresário de pequeno porte não optasse pelo SIMPLES, ele seria tributado em outro sistema (lucro presumido ou lucro real), que aqui se encontram em um papel subsidiário, aplicando-se na ausência de opção do empresário individual ou coletivo.

Nesses dois regimes, estará o empresário obrigado, por força de leis especiais de natureza tributária, a escriturar os livros Diário e Razão (se tributado com base no lucro real) ou os mesmos livros Caixa e Registro de Inventário (se tributado com base no lucro presumido).

Veja-se que esta também tem sido a posição da Secretaria da Receita Federal e da jurisprudência: 


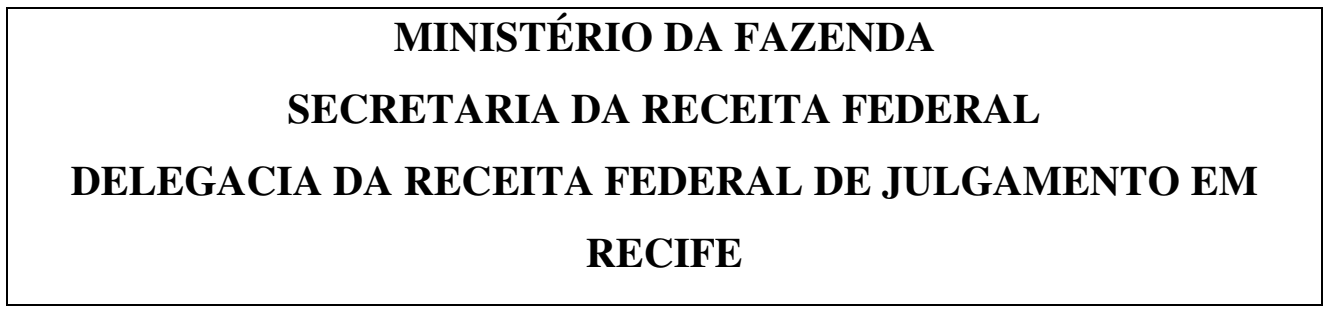

$4^{a}$ TURMA

ACÓRDÃO No 1210 de 19 de abril de 2002

ASSUNTO: Imposto sobre a Renda de Pessoa Jurídica - IRPJ

EMENTA: EMPRESA DE PEQUENO PORTE - RECOLHIMENTO PELO SIMPLES SEM O EXERCÍCIO DA OPÇÃO. Para gozo dos benefícios instituídos pela Lei 9.317/96, é indispensável que a pessoa jurídica obtenha o registro de microempresa ou de empresa de pequeno porte na SRF. Não se considera empresa de pequeno porte a pessoa jurídica cujo registro não seja comprovado. Mantendo a pessoa jurídica escrituração na forma da legislação comercial, de maneira a possibilitar a apuração do lucro real, a tributação se fará segundo as regras que o regem. NULIDADE DO AUTO DE INFRAÇÃO. Não estando presente no auto de infração nenhuma das hipóteses de nulidades descritas nos incisos I e II do art. 59 do Decreto $n^{o}$ 70.235/72, não há que se cogitar de sua nulidade.

MINISTÉRIO DA FAZENDA
SECRETARIA DA RECEITA FEDERAL
DELEGACIA DA RECEITA FEDERAL DE JULGAMENTO EM
FORTALEZA

$1^{\circ}$ TURMA

ACÓRDÃO No 3357 de 25 de agosto de 2003

ASSUNTO: Imposto sobre a Renda de Pessoa Jurídica - IRPJ

EMENTA: ARBITRAMENTO DO LUCRO. FALTA DE APRESENTAÇÃO DOS LIVROS CONTÁBEIS E FISCAIS. No caso de tributação pelo Lucro 
Real, a falta de apresentação dos livros contábeis e fiscais, aliada a não apresentação de documentos correlatos, torna válida a adoção do arbitramento do lucro da pessoa jurídica. MICROEMPRESA. APRESENTAÇÃO DA DECLARAÇÃO DE RENDIMENTOS PELO LUCRO REAL. Mesmo enquadrando-se como microempresa, tiver optado pela tributação pelo Lucro Real, considera-se que o contribuinte abdicou da isenção de que teria direito, obrigando-se, no caso, à escrituração comercial e fiscal, para fins de comprovação dos resultados. Legítimo o arbitramento do lucro pela falta de apresentação do Livro Diário e do Livro Razão, bem como da documentação correlata. TRIBUTAÇÃO REFLEXA. IMPOSTO DE RENDA RETIDO NA FONTE. CONTRIBUIÇÃO SOCIAL SOBRE O LUCRO LÍQUIDO. Aplica-se às exigências ditas reflexas o que foi decidido quanto à exigência matriz, devido à íntima relação de causa e efeito entre elas. JUROS DE MORA COM BASE NA TRD. Com fundamento na determinação contida no art. $1^{o}$ da Instrução Normativa SRF $n^{o}$ 032/97, é de se cancelar a parcela do crédito tributário correspondente à exigência da Taxa Referencial Diária - TRD, no período de 04.02.91 a 29.07.91, remanescendo, neste período, juros de mora a razão de $1 \%$ ao mês calendário ou fração, de acordo com a legislação pertinente. Exercício: 1991, 1992, 1993

Assim, mesmo na época em que esteve vigente a Lei n. 9.317/96, deve-se concluir que não existe hipótese em que a microempresa esteja dispensada do dever de escriturar qualquer livro, pois, mesmo que não exigida a escrituração comercial, seria obrigatória a escrituração fiscal.

As dúvidas sobre a matéria foram parcialmente esclarecidas com o advento da Lei Complementar n. 123/06.

Referida lei facilitou a tarefa do exegeta ao trazer em seu bojo a definição de microempresa ou empresa de pequeno porte, fazendo uma interpretação autêntica do disposto no Código Civil, nos termos seguintes: 
Art. 3. ${ }^{\circ}$ Para os efeitos desta Lei Complementar, consideram-se microempresas ou empresas de pequeno porte a sociedade empresária, a sociedade simples e o empresário a que se refere o art. 966 da Lei $n$. 10.406, de 10 de janeiro de 2002, devidamente registrados no Registro de Empresas Mercantis ou no Registro Civil de Pessoas Jurídicas, conforme o caso, desde que:

I - no caso das microempresas, o empresário, a pessoa jurídica, ou a ela equiparada, aufira, em cada ano-calendário, receita bruta igual ou inferior a $R \$ 240.000,00$ (duzentos e quarenta mil reais);

II - no caso das empresas de pequeno porte, o empresário, a pessoa jurídica, ou a ela equiparada, aufira, em cada ano-calendário, receita bruta superior a $R \$ 240.000,00$ (duzentos e quarenta mil reais) e igual ou inferior a $R \$ 2.400 .000,00$ (dois milhões e quatrocentos mil reais).

Assim, não restam mais dúvidas sobre a definição de microempresa e empresa de pequeno porte referida no Código Civil, devendo-se considerar, para todos os efeitos, revogada a definição de pequeno comerciante contida no Decreto n. 64.567/69.

A Lei Complementar n. 123/06 não regulou a escrituração mercantil das microempresas e empresas de pequeno porte, restando, portanto, tais espécies empresariais dispensadas de escrituração completa (livro Diário) nos termos do Código Civil, acima referidos.

Em relação à escrita fiscal, a Lei Complementar n. 123/06 estabeleceu na Seção VII, sob o título Das Obrigações Fiscais Acessórias, os deveres escriturais das microempresas e empresas de pequeno porte (art. 26 e parágrafos).

Para tanto, foram estabelecidas novamente duas espécies de obrigações escriturais, conforme haja ou não opção pela tributação no sistema SIMPLES, nos termos do quadro seguinte: 
Quadro 7: obrigações escriturais das microempresas e empresas de pequeno porte conforme a Lei Complementar n. 123/06

\begin{tabular}{|c|c|c|}
\hline Opção de sistema & $\begin{array}{l}\text { Optante pelo } \\
\text { SIMPLES }\end{array}$ & $\begin{array}{l}\text { Não optante pelo } \\
\text { SIMPLES }\end{array}$ \\
\hline $\begin{array}{l}\text { Fundamento legal das } \\
\text { obrigações escriturais }\end{array}$ & $\begin{array}{c}\text { Arts. } 25 \text { e 26, I e II, da } \\
\text { Lei Complementar } n . \\
123 / 06 .\end{array}$ & $\begin{array}{c}\text { Art. 26, } \$ 2^{\circ} \text {, da Lei } \\
\text { Complementar } n . \\
123 / 06 .\end{array}$ \\
\hline $\begin{array}{c}\text { Obrigações acessórias } \\
\text { tributárias de } \\
\text { natureza escritural }\end{array}$ & $\begin{array}{c}\text { Não há obrigações } \\
\text { escriturais, devendo, } \\
\text { entretanto: } \\
\text { I - apresentar } \\
\text { anualmente, à } \\
\text { Secretaria da Receita } \\
\text { Federal, declaração } \\
\text { única e simplificada de } \\
\text { informações } \\
\text { socioeconômicas e } \\
\text { fiscais } \\
\text { II - emitir documento } \\
\text { fiscal de venda ou } \\
\text { prestação de serviço, de } \\
\text { acordo com instruções } \\
\text { expedidas pelo Comitê } \\
\text { Gestor; } \\
\text { III - manter em boa } \\
\text { ordem e guarda os } \\
\text { documentos que } \\
\text { fundamentaram a } \\
\text { apuração dos impostos } \\
\text { e contribuições devidos, } \\
\text { enquanto não decorrido } \\
\text { o prazo decadencial e } \\
\text { não prescritas } \\
\text { eventuais ações que } \\
\text { lhes sejam pertinentes. }\end{array}$ & $\begin{array}{l}\text { Manter livro-caixa em } \\
\text { que será escriturada } \\
\text { sua movimentação } \\
\text { financeira e bancária. }\end{array}$ \\
\hline
\end{tabular}

Verifica-se, portanto, que, em relação às microempresas e empresas de pequeno porte optantes pelo SIMPLES, tem-se novamente o sistema estabelecido pela Lei n. 7.256/84, pois estarão dispensadas da escrituração mercantil por força da dispensa estabelecida no Código Civil e da escrituração fiscal por força do art. 26, I e II, da Lei 
Complementar n. 123/06, devendo apenas manter os documentos exigidos por este último diploma.

Em relação àquelas não optantes, também dispensadas da escrituração mercantil, ficou mantida a exigência de escrituração fiscal através da elaboração de livro Caixa, suprimida a necessidade do Livro Registro de Inventário. 


\section{OS LIVROS E OS MEIOS ALTERNATIVOS DE ESCRITURAÇÃO}

Historicamente, a escrituração foi realizada em livros do comerciante, no qual este anotava seus créditos e suas dívidas para com terceiros.

Os lançamentos produzidos pela escrituração, ainda que realizados por sistema eletrônico, nos termos das referências do Código Civil, precisam ser transcritos em papel. Assim, por mais que existam meios mais modernos para a elaboração e manutenção da escrituração empresarial (arquivos magnéticos, CD-ROM, etc.), nossa legislação civil e comercial ainda não superou a redução a termo, ou melhor, a livros, conjunto de folhas ou fichas, de todo o processo escritural.

Em outras palavras, temos que, infelizmente, ainda não chegamos, na legislação nacional, a meios mais modernos que dispensem a utilização da escrita em papel.

No entanto, a Instrução Normativa do Departamento Nacional de Registro do Comércio (DNRC) n. 102, de 25 de abril de 2006 (que dispõe sobre a autenticação de instrumentos de escrituração dos empresários, sociedades empresárias, leiloeiros e tradutores públicos e intérpretes comerciais), avança nesta regulamentação, permitindo outras formas compatíveis com os sistemas mais modernos de escrituração.

Art. $2^{o}$ São instrumentos de escrituração dos empresários e das sociedades empresárias:

I - livros, em papel;

II - conjunto de fichas avulsas (art. 1.180 - CC/2002);

III - conjunto de fichas ou folhas contínuas (art. 1.180 - CC/2002); 
IV - livros em microfichas geradas através de microfilmagem de saída direta do computador (COM);

$V$ - livros digitais.

Parágrafo único. O empresário ou a sociedade empresária que adotar o sistema de fichas de lançamentos poderá substituir o livro Diário pelo livro Balancetes Diários e Balanços, observadas as mesmas formalidades extrínsecas exigidas para aquele (art. 1.185 - CC/2002).

Essa última norma ainda preceitua que:

Art. $9^{\circ}$ Os instrumentos de escrituração dos empresários e das sociedades empresárias conterão termos de abertura e de encerramento, que indicarão:

I - termo de abertura:

a) o nome empresarial do empresário ou da sociedade empresária a que pertença o instrumento de escrituração;

b) o Número de Identificação do Registro de Empresas - NIRE e a data do arquivamento dos atos constitutivos ou do ato de conversão de sociedade simples em sociedade empresária pela Junta Comercial;

c) o município da sede ou filial;

d) a finalidade a que se destina o instrumento de escrituração;

e) o número de ordem do instrumento de escrituração;

f) a quantidade de:

f.1 - folhas, se numeradas apenas no anverso;

f.2 - páginas, se numeradas no anverso e verso;

f.4-fotogramas, se microfichas; $e$

f.5 - registros, se livro digital;

g) o número da inscrição no Cadastro Nacional da Pessoa Jurídica CNPJ, administrado pela Secretaria da Receita Federal. 
II - termo de encerramento:

a) o nome empresarial do empresário ou da sociedade empresária a que pertença o instrumento de escrituração;

b) o fim a que se destinou o instrumento escriturado;

c) o período a que se refere a escrituração;

d) o número de ordem do instrumento de escrituração;

e) a quantidade de:

e.1 - folhas, se numeradas apenas no anverso;

e.2 - páginas, se numeradas no anverso e verso;

e.4-fotogramas, se microfichas; $e$

e.5 - registros, se livro digital;

$\S 1^{\circ}$ No caso de livro em papel, do termo de encerramento do livro Diário com escrituração resumida, deverá constar relação que identifique todos os livros auxiliares a ele associados, com indicação da finalidade de cada um deles e seus respectivos números seqüenciais. Cada livro auxiliar, no respectivo termo de encerramento, deverá indicar o(s) número(s) do $(s)$ livro(s) Diário(s) com escrituração resumida a que esteja $(m)$ associado(s).

$\S 2^{\circ}$ Existindo erro ou omissão de algum dado obrigatório do termo de abertura elou encerramento, no livro em papel, poderá ser feita ressalva na própria folha ou página, a qual deverá ser assinada pelos mesmos signatários do termo e homologada pelo autenticador do instrumento pela Junta Comercial, mediante termo de homologação por esse datado e assinado.

Art. 10. Os termos de abertura e de encerramento serão datados $e$ assinados pelo empresário, administrador de sociedade empresária ou procurador e por contabilista legalmente habilitado, com indicação do número de sua inscrição no Conselho Regional de Contabilidade - CRC e dos nomes completos dos signatários e das respectivas funções (art. $7^{\circ}$, Decreto $n$. 64.567/69). 
$\S 1^{\circ}$ Não havendo contabilista habilitado na localidade onde se situa a sede do empresário ou da sociedade empresária ou a filial, os termos de abertura e de encerramento serão assinados, apenas, pelo empresário, administrador de sociedade empresária ou procurador (art. 1.182 CC/2002, C/C parágrafo único, art. $7^{\circ}$ do Decreto $\left.n .64 .567 / 69\right)$.

$\S 2^{\circ}$ Para efeito do parágrafo anterior, caberá aos Conselhos Regionais de Contabilidade informar às Juntas Comerciais as localidades onde não haja profissional habilitado ( $\$ 2^{o}$, art. $3^{o}$, Decreto $\left.n .64 .567 / 69\right)$.

$\S 3^{\circ}$ No caso de assinatura por procurador, a procuração deverá conter os poderes para a prática do ato, ser arquivada na Junta Comercial e anotada nos registros de autenticação de livros.

Art. 11. Nas fichas ou folhas que substituírem os livros, para o caso de escrituração mecanizada ou eletrônica, os termos de abertura e de encerramento serão apostos, respectivamente, como segue:

I - fichas ou folhas contínuas: no anverso da primeira e no verso da última dobra de cada bloco, que receberá número de ordem (art. $8^{o}$, Decreto $n^{o}$ 64.567/69);

II - fichas avulsas: na primeira e última ficha de cada conjunto (art. $9^{\circ}$, Decreto $n$. 64.567/69).

Art. 12. Lavrados os termos de abertura e de encerramento, os instrumentos de escrituração dos empresários e das sociedades empresárias, de caráter obrigatório, salvo disposição especial de lei, deverão ser submetidos à autenticação pela Junta Comercial (art. 1.181 - CC/2002):

I - antes ou após efetuada a escrituração, quando se tratar de livros, conjuntos de fichas ou folhas contínuas; 
II - após efetuada a escrituração, quando se tratar de microfichas geradas através de microfilmagem de saída direta do computador (COM) e de livros digitais.

$\S 1^{\circ} \mathrm{O}$ empresário e a sociedade empresária poderão fazer autenticar livros não obrigatórios (Parágrafo único, art. 1.181 - CC/2002).

$\S 2^{\circ}$ É dispensado das exigências deste artigo o pequeno empresário a que se refere o art. 970, da Lei n. 10.406, de 10 de janeiro de 2002, que não está obrigado a seguir um sistema de contabilidade com base na escrituração uniforme de seus livros, em correspondência com a documentação respectiva, nem a levantar anualmente o balanço patrimonial e o de resultado econômico (art. 1.179 e $\left.\S 2^{\circ}-C C / 2002\right)$.

Art. 13. A Junta Comercial procederá às autenticações previstas nesta Instrução por termo, que conterá declaração expressa da exatidão dos termos de abertura e de encerramento, bem como o número e a data de autenticação, do seguinte modo:

I - nos livros, será aposto na primeira página numerada (alínea “a”, art. 12 do Decreto n. 64.567/69);

II - nas fichas ou folhas contínuas, será aposto no anverso da primeira dobra de cada bloco;

III - nas fichas avulsas, será aposto na primeira ficha de cada conjunto e todas as demais serão obrigatoriamente autenticadas com o sinete da Junta Comercial e rubrica do autenticador sobre esse (art. 9', Decreto $n$. 64.567/69);

$I V$ - nos livros digitais deverá ser observado o LBCD.

$\S 1^{o}$ Em qualquer das hipóteses, o autenticador deverá ser expressamente identificado, com indicação do seu nome completo, em letra de forma legível, ou com a aposição de carimbo. 
$\S 2^{\circ}$ Com o objetivo de resguardar a segurança e inviolabilidade dos instrumentos de escrituração dos empresários e das sociedades empresárias, recomenda-se a autenticação destes por meio de etiqueta adesiva com requisitos de segurança, atendidos os procedimentos $e$ requisitos quanto a posição e conteúdo do termo e identificação dos signatários.

Art. 14. Quando se tratar de livros digitais, com o objetivo de resguardar a segurança e inviolabilidade dos instrumentos de escrituração dos empresários e das sociedades empresárias:

I - devem ser assinados por contabilistas legalmente habilitados e pelo empresário ou sociedade empresária, com certificado digital, de segurança mínima tipo A3, de acordo com as regras da ICP Brasil, antes de serem submetidos à autenticação pelas Juntas Comerciais;

II - após autenticados pelas Juntas Comerciais, devem ser submetidos pelo empresário ou sociedade empresária, anualmente, pelo menos, à inserção de novo selo cronológico digital atualizado tecnologicamente, que utilizará certificado digital de segurança mínima de nível 3, sob pena de não valer como prova.

$\S 1^{o}$ As Juntas Comerciais deverão autenticar os livros digitais com certificado digital, de segurança mínima tipo A3, e inserir, em cada autenticação, selo cronológico digital.

$\S 2^{o}$ As Juntas Comerciais deverão inserir, anualmente, no conjunto de hash dos livros digitais autenticados, selo cronológico digital.

$\S 3^{\circ}$ Os certificados digitais e o selo cronológico digital mencionados neste artigo deverão observar conformidade com as regras da ICP Brasil. 
Com base na Instrução Normativa do Departamento Nacional de Registro do Comércio (DNRC), a Junta Comercial do Estado de São Paulo (JUCESP) exige os seguintes requisitos para a autenticação dos $\operatorname{livros}^{114}$ :

- Livros Encadernados:

- folhas/páginas seqüencialmente numeradas (tipograficamente, eletronicamente, mecanicograficamente ou por processamento de dados);

- termo de abertura no anverso da $1^{a}$ (primeira) folha/página numerada:

- termo de encerramento no verso da última folha/página numerada.

- Conjunto de fichas ou folhas soltas:

- fichas ou folhas seqüencialmente numeradas (tipograficamente, eletronicamente, mecanicograficamente ou por processamento de dados);

- termo de abertura no anverso da $1^{a}$ (primeira) ficha ou folha numerada;

- termo de encerramento no verso da última ficha ou folha numerada.

- Conjunto de folhas contínuas:

- folhas seqüencialmente numeradas (tipograficamente, eletronicamente, mecanicograficamente ou por processamento de dados);

- termo de abertura no anverso da $1^{a}$ (primeira) folha numerada;

- termo de encerramento no verso da última folha numerada.

- Microfichas:

- microfichas numeradas;

- fotogramas numerados seqüencialmente;

114 SÃO PAUlO. Junta Comercial do Estado de São Paulo. Disponível em < http://www.jucesp.sp.gov.br/livros.htm>. Acesso em 26 mar. 2006. 
- termo de abertura no $1^{o}$ (primeiro) fotograma numerada da $1^{a}$ (primeira) microficha numerada;

- termo de encerramento no último fotograma numerado da última microficha numerada.

Verifica-se, pois, que a escrituração poderá ser elaborada totalmente em meios eletrônicos (como hoje sói acontecer) ${ }^{115}$.

A doutrina costuma apontar duas sortes de requisitos da escrituração empresarial: extrínsecos e intrínsecos.

Os requisitos extrínsecos, ou de ordem externa, seriam relativos às formalidades de autenticação pela Junta Comercial, lavratura dos termos de abertura e encerramento.

Já os requisitos intrínsecos dizem respeito às formalidades internas da escrituração empresarial, abrangendo a forma contábil necessária, a ausência de borrões, rasuras, etc.; além da escrituração no idioma nacional.

Nesse sentido, a Resolução CFC n. 563/83, que aprova a Norma Brasileira de Contabilidade NBC T 2.1 - Das Formalidades da Escrituração Contábil, estabelece os seguintes requisitos intrínsecos para a escrituração:

A escrituração será executada:

a) em idioma e moeda corrente nacionais;

b) em forma contábil;

c) em ordem cronológica de dia, mês e ano;

115 Já existe regulamentação da forma de manutenção de registros eletrônicos de escrituração. Nesse sentido a Resolução CFC n. 1.020/05, que aprova a Norma Brasileira de Contabilidade NBC T 2.8 - Das Formalidades da Escrituração Contábil em Forma Eletrônica. 
d) com ausência de espaços em branco, entrelinhas, borrões, rasuras, emendas ou transportes para as margens;

e) com base em documentos de origem externa ou interna ou, na sua falta, em elementos que comprovem ou evidenciem fatos e a prática de atos administrativos.

A importância dos requisitos mencionados (extrínsecos e intrínsecos) está intimamente ligada ao valor probante da escrituração. Não observadas as formalidades necessárias, a escrituração perde seu valor probante junto às autoridades administrativas e judiciais, assunto que aprofundaremos mais adiante.

\subsection{Classificação dos livros e seus critérios}

Como vimos no tópico anterior, nem só de livros encadernados pode ser formada a escrituração empresarial. Há também a possibilidade de se estabelecê-la em folhas soltas, microfichas, meios eletrônicos, entre outros processos.

No entanto, a doutrina comercialista, ao se referir aos meios utilizados pela escrituração, faz normalmente alusão aos "livros" comerciais, talvez pela importância histórica que tiveram. E tal referência não deixa de ser abrangente, pois, mesmo que sejam utilizadas outras formas que não os livros encadernados, aquelas terão inegável similaridade com estes, dadas as necessidades de redução ao meio papel, numeração, organização, etc.

De qualquer modo, utilizaremos aqui, na esteira da doutrina, a expressão "livro" em seu sentido mais amplo, compreendendo todas as formas ou instrumentos de escrituração comercial previstos na IN 102/06 do DNRC. 
Várias classificações são propostas pela doutrina para os livros comerciais.

Neves e Viceconti propõem a seguinte classificação ${ }^{116}$ :

Quadro 8: classificação dos livros (cf. Neves e Viceconti)

\begin{tabular}{|c|c|c|c|}
\hline \multirow{4}{*}{$\begin{array}{l}\text { Quanto à } \\
\text { finalidade }\end{array}$} & \multirow[b]{3}{*}{ Obrigatórios } & $\begin{array}{l}\text { Pelo Código } \\
\text { Civil (1) }\end{array}$ & Diário \\
\hline & & Por leis fiscais & $\begin{array}{c}\text { Todos os livros } \\
\text { fiscais } \\
\text { determinados } \\
\text { pela legislação } \\
\text { federal, estadual } \\
\text { e municipal }\end{array}$ \\
\hline & & $\begin{array}{c}\text { Pela Lei n. } \\
6.404 / 76\end{array}$ & $\begin{array}{c}\text { Atas de } \\
\text { assembléias } \\
\text { gerais, Atas e } \\
\text { Pareceres do } \\
\text { Conselho Fiscal, } \\
\text { Atas das } \\
\text { Reuniões da } \\
\text { Diretoria. } \\
\text { Presença dos } \\
\text { Acionistas, } \\
\text { Registro de } \\
\text { Ações } \\
\text { Nominativas, } \\
\text { Transferências } \\
\text { de Ações } \\
\text { Nominativas (2) }\end{array}$ \\
\hline & Facultativos & \multicolumn{2}{|c|}{$\begin{array}{c}\text { Razão (3), Caixa, Contas-Correntes, } \\
\text { Bancos, Fornecedores, } \\
\text { Representantes, Registro de } \\
\text { Vencimentos, Controle de Estoques, } \\
\text { Identificação de Bem, etc. }\end{array}$} \\
\hline $\begin{array}{l}\text { Quanto à } \\
\text { natureza }\end{array}$ & Cronológicos & $\begin{array}{c}\text { Ordem } \\
\text { cronológica } \\
\text { exclusiva }\end{array}$ & Diário \\
\hline
\end{tabular}

${ }^{116}$ NEVES, Silvério das; VICECONTI, Paulo Eduardo Vilchez. Contabilidade básica. São Paulo: Frase, 2000. p. 61. 


\begin{tabular}{|c|c|c|c|}
\hline & & $\begin{array}{l}\text { Ordem } \\
\text { cronológica } \\
\text { secundária }\end{array}$ & $\begin{array}{l}\text { Todos os demais } \\
\text { livros que, } \\
\text { embora } \\
\text { sistemáticos, } \\
\text { obedeçam à } \\
\text { ordem } \\
\text { cronológica }\end{array}$ \\
\hline & Sistemáticos & \multicolumn{2}{|c|}{$\begin{array}{l}\text { Todos os livros, com exceção do } \\
\text { Diário, são primordialmente } \\
\text { sistemáticos e secundariamente } \\
\text { cronológicos }\end{array}$} \\
\hline \multirow{2}{*}{$\begin{array}{l}\text { Quanto à } \\
\text { utilidade }\end{array}$} & Prin & \multicolumn{2}{|c|}{ Diário e Razão (1) } \\
\hline & Auxiliares & \multicolumn{2}{|c|}{ Todos os outros livros citados } \\
\hline \multicolumn{4}{|c|}{$\begin{array}{l}\text { (1) Adaptação do texto do autor no sentido de adequar à legislação atual: } \\
\text { no original consta: "Pelo Código Comercial"; } \\
\text { (2) Fazem parte da chamada escrituração simplesmente memorial, não } \\
\text { tratada neste trabalho; } \\
\text { (3) Livro Razão: É de escrituração obrigatória para os contribuintes } \\
\text { sujeitos à tributação do Imposto de Renda com base no Lucro Real (art. } 18 \\
\text { da Lei } n .8 .218 / 91 \text { ). }\end{array}$} \\
\hline
\end{tabular}

Paulo Roberto C. Arnoldi elabora a seguinte classificação ${ }^{117}$ :

Quadro 9: classificação dos livros (cf. Arnoldi)

\begin{tabular}{|c|c|c|}
\hline \multirow{5}{*}{ Obrigatórios } & $\begin{array}{c}\text { Geral para todos os } \\
\text { comerciantes - Diário }\end{array}$ \\
& Específicos - para os \\
comerciantes que \\
emitam duplicatas: \\
Legais & Registro de \\
& Duplicatas; \\
& - Para os armazéns \\
& gerais; \\
& - Para os corretores; \\
& - Para os intérpretes; \\
& - Para as sociedades \\
& anônimas. \\
\hline
\end{tabular}

${ }_{117}$ ARNOLDI, Paulo Roberto Colombo. Teoria Geral do Direito Comercial. São Paulo: Saraiva, 1998. p. 112-3. 


\begin{tabular}{|c|c|c|}
\hline \multirow{2}{*}{ Fiscais } & $\begin{array}{c}\text { Exigidos pela } \\
\text { legislação tributária } \\
\text { de acordo com a } \\
\text { atividade ou atos } \\
\text { característicos } \\
\text { praticados pelos } \\
\text { comerciantes e } \\
\text { sujeitos a certos } \\
\text { tributos }\end{array}$ \\
\cline { 2 - 3 } & Contábeis & $\begin{array}{c}\text { Essenciais - } \\
\text { necessários para uma } \\
\text { boa contabilidade }\end{array}$ \\
\hline Facultativos & Todos aqueles que o comerciante entender \\
& necessários e úteis para o seu controle e \\
contabilidade
\end{tabular}

Passaremos em revista os principais livros empresariais nos tópicos seguintes.

\subsubsection{Diário}

O Diário é o livro empresarial por excelência. Consubstancia o que se costuma denominar escrituração empresarial completa, por envolver o controle e os lançamentos que envolvem todas as rubricas (patrimoniais e de resultado), estabelecidas no plano de contas elaborado pelo empresário.

Nos dizeres de J. X. Carvalho de Mendonça, "O Diário é o livro para o qual convergem os lançamentos da casa de comércio; é o centralizador de todo o movimento da contabilidade. Nele deve-se encontrar fielmente mencionado tudo quanto diz respeito ao patrimônio do comerciante, apresentando o desenvolvimento completo da sua posição econômica"118.

${ }^{118}$ MENDONÇA, José Xavier Carvalho de. Op. cit., 1906. p. 23. 
Ressalvadas as dispensas legais (como a do pequeno empresário), é um livro obrigatório para todos os empresários. Também o direito italiano prevê a obrigatoriedade do livro diário (giornale), no art. 2.214 do Código Civil italiano, juntamente com o livro de Inventário (inventari), dispensando, igualmente, da exigência os pequenos empresários (piccoli imprenditori).

Os termos da legislação italiana são transcritos a seguir:

\section{Art. 2.214. Libri obbligatori e altre scritture contabili}

L'imprenditore che esercita un'attività commerciale (2195) deve tenere il libro giornale e il libro degli inventari. Deve altresì tenere le altre scritture contabili che siano richieste dalla natura e dalle dimensioni dell'impresa (att. 200) e conservare ordinatamente per ciascun affare gli originali delle lettere, dei telegrammi e delle lettere ricevute, nonché le copie delle lettere, dei telegrammi e delle fatture spedite (2709 e seguenti). Le disposizioni di questo paragrafo non si applicano ai piccoli imprenditori (2083).

Por possuir tamanha abrangência de lançamentos, possibilita o controle completo da atividade econômica e financeira do empreendimento, viabilizando a apuração do lucro contábil e viabilizando a elaboração de todas as demonstrações.

No Diário deverão ser lançados, dia a dia $^{119}$, os atos ou operações da atividade empresarial, bem como aqueles que modifiquem ou possam vir a modificar a situação patrimonial do empresário. Excepcionalmente, os lançamentos no Diário podem ser somente dos saldos mensais (no caso de contas cujas operações sejam numerosas ou realizadas fora da sede do estabelecimento). Para isso, entretanto, deverão ser escriturados livros auxiliares destinados à escrita das transações correspondentes efetuadas no mês.

Não estará regular, portanto, a escrituração do Diário feita meramente através de lançamentos de saldos mensais, sem a escrituração paralela de livros auxiliares

\footnotetext{
${ }^{119}$ A exigência de lançamentos dia a dia também consta do art. 2.216 do Código Civil italiano, segundo o qual "Il libro giornale deve indicare giorno per giorno le operazioni relative all'esercizio dell'impresa".
} 
(p. ex.: Contas Correntes, Registro de Duplicatas, etc.) que permitam visualizar os lançamentos do mês ${ }^{120}$.

São requisitos dos lançamentos no livro Diário (partidas de Diário) os seguintes: 1) data e local da operação econômica; 2) Nome, código, título ou rubrica das contas envolvidas a débito e a crédito; 3) histórico da transação; 4) valores envolvidos, expressos em moeda nacional.

Exemplifiquemos a seguir o lançamento respectivo, na hipótese de uma sociedade limitada que adquire monitores para computador (componentes do estoque) no valor de $\mathrm{R} \$ 50.000,00$, pagando à vista em 27/3/2006.

Quadro 10: exemplo de lançamento em livro Diário ${ }^{121}$

\begin{tabular}{|c|c|c|c|c|c|}
\hline \multicolumn{2}{|c|}{ Data/Local } & \multirow{2}{*}{$\begin{array}{l}\begin{array}{c}\text { Nome das contas } \\
\text { envolvidas e } \\
\text { histórico }\end{array} \\
\text { Estoques } \\
\text { a Caixa } \\
\text { Compra de } \\
\text { monitores } \\
\text { (estoque), conforme } \\
\text { Nota Fiscal } 20.402 \text {, } \\
\text { modelo 1, de } \\
\text { fornecedor A }\end{array}$} & \multirow{2}{*}{$\begin{array}{l}\begin{array}{c}\text { Código da } \\
\text { Conta }\end{array} \\
10.1 \\
1.1\end{array}$} & \multirow{2}{*}{$\begin{array}{l}\text { Débito } \\
50.000\end{array}$} & \multirow{2}{*}{$\begin{array}{l}\text { Crédito } \\
50.000\end{array}$} \\
\hline \multirow[t]{3}{*}{$\begin{array}{l}\text { Filial } \\
\text { ABC }\end{array}$} & 27 & & & & \\
\hline & & & & & \\
\hline & & & & & \\
\hline
\end{tabular}

O Diário deve ser único, não podendo o empresário ter mais de um livro com a mesma rubrica e finalidade. Poderá ser desenvolvido, entretanto, livro Diário auxiliar, considerado como livro facultativo.

\footnotetext{
${ }^{120}$ Escrituração nessa situação, conforme o entendimento da Secretaria da Receita Federal, enseja o arbitramento do lucro da pessoa jurídica, conforme se verifica no acórdão n. 7.600, de 12 de maio de 2005, Delegacia de Julgamento do Rio de Janeiro, 4" turma: "EMENTA: IRPJ. PESSOA JURÍDICA TRIBUTADA COM BASE NO LUCRO REAL. INOBSERVÂNCIA DE OBRIGAÇÕES ACESSÓRIAS. ARBITRAMENTO. Legítimo o arbitramento, quando o contribuinte, sujeito à tributação com base no lucro real, escritura os Livros Diário e Razão em partidas mensais, sem possuir registros auxiliares que permitam individualizar os lançamentos ocorridos no mês, e deixa, ademais, de apresentar ao Fisco os documentos fiscais que dão respaldo à escrituração. Ano-calendário: 1997”.

${ }^{121}$ O modelo trazido é o de Diário bicolunado, um dos recomendados por José Carlos Marion (op. cit. p. 216). Outros modelos também são utilizados.
} 
Por algum tempo foi muito utilizado o livro denominado "Borrador" ou "Borrador do Diário", livro auxiliar usado como uma espécie de primeira linha de escrituração do dia-a-dia do empresário, da qual se fazia a transcrição posterior e fiel, com minúcia e esmero, para o livro Diário.

\subsubsection{Razão}

O livro Razão é, juntamente com o Diário, um dos mais tradicionais da contabilidade. Não é exigido como obrigatório pela legislação comercial, mas passou a sêlo por efeito da legislação tributária que regula o imposto sobre a renda, para os empresários tributados com base no lucro real.

Nas palavras de José Carlos Marion, o Razão “Consiste no agrupamento de valores em contas de mesma natureza e de forma racional. Em outras palavras, o registro no Razão é realizado em contas individualizadas, assim, teremos um controle por conta. Por exemplo, abrimos uma conta Caixa, e registramos todas as operações que, evidentemente, afetam o Caixa nesta conta, debitando ou creditando e, a qualquer momento, apuramos o saldo"122.

Do Razão surge a expressão muito utilizada pelos contabilistas "Razonete", ou "Razonete em T", que nada mais é do que um gráfico simplificado para lançamentos contábeis por conta específica, que lembra o formato da letra "T" do alfabeto.

Nos termos da explicação também referida pelo autor supracitado, no princípio, o Razão tinha como configuração um livro no qual, para cada página, havia uma conta representada. Aos poucos, foi havendo a substituição por fichas avulsas até o surgimento da informatização.

\footnotetext{
${ }^{122}$ MARION, José Carlos. Op. cit., 1997. p. 330.
} 
Um exemplo melhor elucidará a questão. Seguindo o lançamento já utilizado no Diário referido no tópico anterior (compra de monitores, conforme Nota Fiscal 20.402, modelo 1, de fornecedor A), e supondo que as contas já possuíssem outros lançamentos (saldos iniciais - SI), teríamos o seguinte como saldos finais (SF) e lançamentos a débito (D) e crédito (C):

\section{Razonetes (em “T”)}

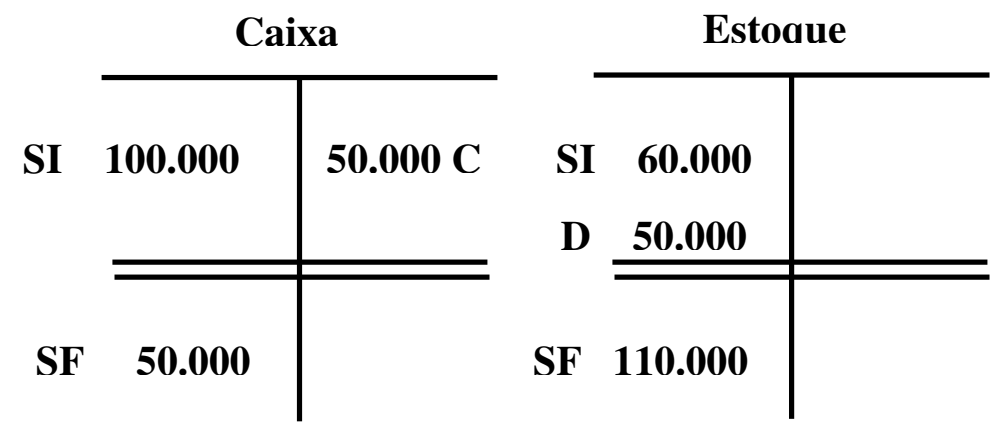

Quadro 11: Livro Razão ${ }^{123}$

\begin{tabular}{|c|c|c|c|c|c|}
\hline \multicolumn{2}{|c|}{ Conta: Caixa } & \multicolumn{4}{|c|}{ Código 1.2.3 } \\
\hline \multirow{2}{*}{ Data } & \multirow{2}{*}{ Histórico } & \multirow{2}{*}{ Débito } & \multirow{2}{*}{ Crédito } & \multicolumn{2}{|c|}{ Saldo } \\
\hline & & & & $\mathrm{D} / \mathrm{C}$ & Valores \\
\hline & $\begin{array}{l}\text { Saldo } \\
\text { inicial }\end{array}$ & & & $\bar{D}$ & 100.000 \\
\hline 27/03/2006 & $\begin{array}{c}\text { Compra de } \\
\text { monitores } \\
(N . F . \\
20.402)\end{array}$ & & 50.000 & $\mathrm{C}$ & 50.000 \\
\hline & & & & & \\
\hline
\end{tabular}

\begin{tabular}{|c|c|c|c|c|c|}
\hline \multicolumn{2}{|c|}{ Conta: Estoque } & \multicolumn{4}{|c|}{ Código 1.4.5 } \\
\hline \multirow{2}{*}{ Data } & \multirow{2}{*}{ Histórico } & \multirow{2}{*}{ Débito } & \multirow{2}{*}{ Crédito } & \multicolumn{2}{|c|}{ Saldo } \\
\hline & & & & $\mathrm{D} / \mathrm{C}$ & Valores \\
\hline & $\begin{array}{l}\text { Saldo } \\
\text { inicial }\end{array}$ & & & $\bar{D}$ & 60.000 \\
\hline 27/03/2006 & $\begin{array}{c}\text { Compra de } \\
\text { monitores } \\
(N . F . \\
20.402) \\
\end{array}$ & 50.000 & & $\mathrm{D}$ & 110.000 \\
\hline & & & & & \\
\hline
\end{tabular}

${ }^{123} \mathrm{O}$ modelo trazido é recomendado por José Carlos Marion (op. cit., p. 213). Outros modelos também são utilizados. 
Veja-se que, pela mera observação do Diário, não saberíamos dizer qual o saldo das contas envolvidas na operação econômica exemplificada (compra de monitores). No entanto, pela visualização do Razão, podemos observar que a conta Caixa foi creditada pela saída de dinheiro à vista, restando saldo (devedor) de $\mathrm{R} \$$ 50.000,00 (cinqüenta mil reais) e a conta Estoque foi debitada pela entrada de um equipamento novo, ficando com saldo (devedor) de R \$ 110.000,00 (cento e dez mil reais).

\subsubsection{Caixa}

O livro Caixa é, na verdade, uma especialização do Diário, que registra o que se denomina contabilmente disponível ou disponibilidades, que consiste nos ativos de liquidez imediata, ou seja, quantias em dinheiro de posse do empresário ou aplicações financeiras com tais características.

Para os fins da escrituração mercantil, trata-se de mero livro auxiliar, ao qual não está obrigado o empresário. No entanto, sua utilização se difundiu diante da possibilidade, advinda com a legislação que regula o imposto de renda, de alguns empresários substituírem a escrituração completa pela escrituração do livro Caixa.

Como bem ressalta J. X. Carvalho de Mendonça, "Este livro registra todo o movimento de dinheiro entrado e saído, indicando as importâncias, a pessoa que paga ou recebe e a causa ou o porquê. De ordinário, no lado esquerdo lançam-se os recebimentos ou entradas, e no direito os pagamentos ou saídas (...) O encarregado da caixa dá balanço, todos os dias, após o expediente, e diz-se, que ele fez a sua caixa. Soma as quantias creditadas e as debitadas e verifica a diferença, dinheiro em caixa, que é levada como saldo a seu débito. É também costume, no fim de cada mês, fechar a conta desse mês e passar o saldo para a conta do seguinte" ${ }^{\prime 24}$.

${ }^{124}$ MENDONÇA, José Xavier Carvalho de. Op. cit., 1906. p. 31. 
Para seguirmos o exemplo dado na escrituração do livro Diário e Razão (compra de monitores, conforme Nota Fiscal 20.402, modelo 1, de fornecedor A), a escrituração diária do livro Caixa poderia ser feita, de modo simplificado, na seguinte forma:

Quadro 12: Livro Caixa

Relatório de segunda-feira, 27 de março de 2006

\begin{tabular}{|c|l|c|c|}
\hline Data & \multicolumn{1}{|c|}{ Histórico } & Entrada & Saída \\
\hline & Saldo Anterior & $100.000,00$ & - \\
\hline $27 / 3 / 2006$ & $\begin{array}{l}\text { Compra de monitores (Conforme NF } \\
20.402 \text { - Fornecedor A) }\end{array}$ & - & $50.000,00$ \\
\hline
\end{tabular}

Entradas: R \$ 100.000,00

Saídas: $\mathrm{R} \$ 50.000,00$

Saldo do Dia: $\mathrm{R} \$ 50.000,00$

Saldo do Caixa: $\mathrm{R} \$ 50.000,00$

\subsubsection{Registro de inventário}

Outro livro facultativo, mas que ganhou importância com sua exigência pela legislação tributária, é o livro Registro de Inventário.

O objetivo de referido livro é arrolar os diversos bens em estoque (mercadorias, matérias-primas, produtos intermediários, materiais de embalagem, produtos manufaturados ou em fabricação, etc.) existentes em data determinada (via de regra a data de fechamento do balanço), com determinação de seus valores e identificação especificada de seu conteúdo. 
Para a operação referida nos exemplos anteriores, teríamos o seguinte registro exemplificativo:

Quadro 13: Livro Registro de Inventário

\begin{tabular}{|c|c|c|c|c|c|}
\hline \multicolumn{6}{|c|}{ Registro de Inventário } \\
\hline \multicolumn{6}{|c|}{$\begin{array}{l}\text { Empresa: XXXXX } \\
\text { CNPJ: XXXXX } \\
N^{\circ} \text { Inscrição: XXXX } \\
\text { Folha: XX } \\
\text { Estoques existentes em: } 23 / 07 / 2006\end{array}$} \\
\hline \multirow{2}{*}{$\begin{array}{c}\text { Classificação } \\
\text { fiscal }\end{array}$} & \multirow[b]{2}{*}{ Discriminação } & \multirow[b]{2}{*}{ Unidade } & \multirow{2}{*}{$\begin{array}{l}\text { Quantidade } \\
\text { (m, kg, dz, } \\
\text { etc. })\end{array}$} & \multicolumn{2}{|c|}{ Valores } \\
\hline & & & & Unitário & Total \\
\hline 1.1 .1 & $\begin{array}{c}\text { Centrais de } \\
\text { processamento } \\
\text { de dados } \\
(\mathrm{CPUs}) \\
\end{array}$ & 30 & - & 2.000 & 60.000 \\
\hline 1.1 .2 & $\begin{array}{c}\text { Monitores } \\
\text { (N.F. 20.402) }\end{array}$ & 50 & - & 1.000 & 50.000 \\
\hline
\end{tabular}

Podemos verificar claramente que, na mesma operação, só pudemos visualizar os preços unitários e o número de unidades pela verificação do Registro de Inventário, uma vez que nos livros Diário, Razão e Caixa foram inseridos apenas os valores totais de cada lançamento.

No direito italiano, o livro de inventários tem propósito maior, uma vez que não cuida somente do estoque de bens, mas de todos os ativos e passivos do empresário. Abrangendo todo o patrimônio da empresa, serve referido livro como fundamento para a elaboração do balanço e da conta de lucros e perdas. Isso é o que consta do art. 2.217 do Código Civil Italiano:

\section{Art. 2.217 Redazione dell'inventario}

L'inventario deve redigersi all'inizio dell'esercizio dell'impresa e successivamente ogni anno, e deve contenere l'indicazione e la valutazione delle attività e delle passività relative all'impresa, nonché delle attività e 
delle passività dell'imprenditore estranee alla medesima. L'inventario si chiude con il bilancio e con il conto dei profitti e delle perdite, il quale deve dimostrare con evidenza e verità gli utili conseguiti o le perdite subite. Nelle valutazioni di bilancio l'imprenditore deve attenersi ai criteri stabiliti per $i$ bilanci delle società per azioni, in quanto applicabili (2425). L'inventario deve essere sottoscritto dall'imprenditore entro tre mesi dal termine per la presentazione della dichiarazione dei redditi ai fini delle imposte dirette.

\subsubsection{Registro de Duplicatas}

A escrituração do livro Registro de Duplicatas foi determinada pelo art. 19 da Lei n. 5.474/68, para os empresários individuais ou coletivos que efetuem vendas mercantis entre partes domiciliadas no território brasileiro, com prazo não inferior a 30 (trinta) dias, nos termos transcritos a seguir.

Art. 19. A adoção do regime de vendas de que trata o art. $2^{\circ}$ desta Lei obriga o vendedor a ter e a escriturar o Livro de Registro de Duplicatas.

$\S 1^{\circ}$ No Registro de Duplicatas serão escrituradas, cronologicamente, todas as duplicatas emitidas, com o número de ordem, data e valor das faturas originárias e data de sua expedição; nome e domicílio do comprador; anotações das reformas; prorrogações e outras circunstâncias necessárias.

$\S 2^{\circ}$ Os Registros de Duplicatas, que não poderão conter emendas, borrões, rasuras ou entrelinhas, deverão ser conservados nos próprios estabelecimentos.

$\S 3^{\circ}$ O Registro de Duplicatas poderá ser substituído por qualquer sistema mecanizado, desde que os requisitos deste artigo sejam observados. 
Como se observa, o que determinou a lei foi o destaque de uma das contas que compõem a escrituração dos livros Diário e Razão, qual seja, a conta "Duplicatas a Receber" ou "Duplicatas Emitidas".

Trata-se, portanto, de conta normalmente inserida no ativo circulante (raramente no realizável a longo prazo), representativa dos créditos empresariais pelas vendas a prazo.

Os principais lançamentos constantes do livro em comento são derivados da emissão de duplicatas, pagamento do título, desconto bancário ou operação de faturização. 


\section{OS EFEITOS IMEDIATOS DA ESCRITURAÇÃO: DEMONSTRAÇÕES CONTÁBEIS E FINANCEIRAS}

A consequiência mais imediata da escrituração é a elaboração das demonstrações contábeis.

Isso porque estas consistem em relatórios extraídos da escrituração, contendo em sua estrutura uma parcela maior ou menor dos lançamentos efetuados nas contas, destinando-se a demonstrar aos usuários da escrita contábil alguns aspectos da situação econômica empresarial.

Quando se escritura, lançam-se dados em um substrato, seja este um livro tradicional ou sistema informatizado. No entanto, tais dados lançados na contabilidade normalmente só fazem algum sentido para aqueles que os efetivaram, sendo usualmente inservíveis, em termos de fornecimento de informações aos usuários internos e externos da escrituração.

Assim, o papel principal das demonstrações contábeis é transformar os dados lançados na escrituração em informações úteis aos usuários do processo escritural, através da simplificação, organização e sistematização, visando a uma futura tomada de decisão.

Pode-se dizer, portanto, que as demonstrações contábeis são sempre relatórios ou sínteses da escrituração que apresentam determinadas tendências, enfoques ou objetivos. Para exemplificar o que melhor veremos a seguir, podemos dizer que o balanço patrimonial enfatiza a evidenciação do ativo e do passivo; a demonstração de resultado explica o lucro ou prejuízo existente no período; a demonstração de fluxo de caixa, os valores que ingressaram em referida conta; a DOAR, a situação do capital circulante líquido, e assim por diante. 
Trata-se, portanto, de relatórios específicos para cada propósito, mas com uma mesma fonte, qual seja, a escrituração contábil.

Conceito similar é encontrado em José Carlos Marion: “Os dados coletados pela Contabilidade são apresentados periodicamente aos interessados de maneira resumida e ordenada, formando, assim, os relatórios contábeis. Os relatórios são elaborados de acordo com as necessidades dos usuários. Evidentemente, um relatório sobre o resultado anual de uma farmácia destacará muito menos pormenores que o de uma siderúrgica, que, normalmente, tem um número elevado de proprietários, grande volume de negócios, diversos tipos de impostos a recolher, operações em muitas agências bancárias. Dos inúmeros relatórios que há em Contabilidade, destacam-se aqueles que são obrigatórios de acordo com a legislação brasileira. Esses relatórios são conhecidos como demonstrações financeiras ou, ainda, como demonstrações contábeis". ${ }^{125}$

Embora as demonstrações possam parecer supérfluas para alguns, as conseqüências jurídicas de sua inexistência podem causar sérios efeitos pecuniários, inclusive com arbitramento do lucro para efeito de imposto sobre a renda. Isso é o que se verifica na decisão seguinte em relação à tributação (grifos nossos):

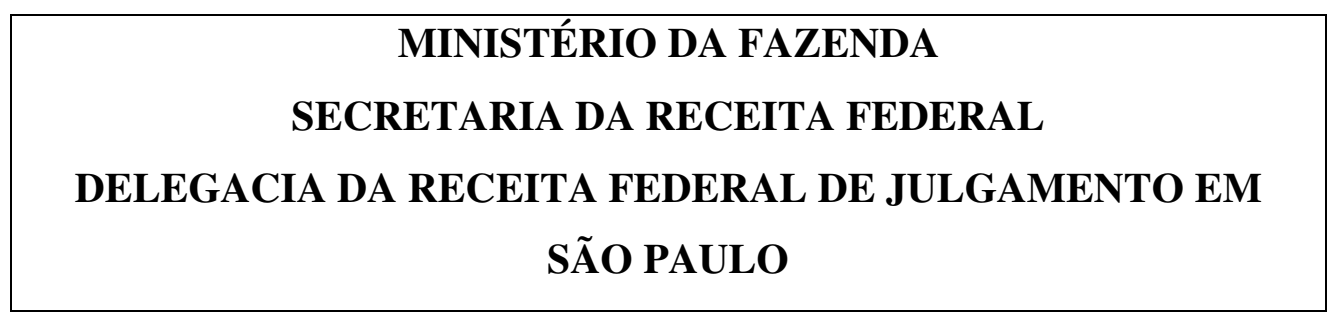

DECISÃO No 2076 de 30 de junho de 1999

ASSUNTO: Imposto sobre a Renda de Pessoa Jurídica - IRPJ

EMENTA: FALTA DE ESCRITURAÇÃO. HIPÓTESE PARA ARBITRAMENTO. A autoridade tributária arbitrará o lucro da pessoa jurídica, que servirá de base de cálculo do imposto, quando o contribuinte

${ }^{125}$ MARION, José Carlos. Op. cit., 2004. p. 43. 
sujeito à tributação com base no lucro real não mantiver a escrituração na forma das leis comerciais e fiscais ou deixar de elaborar balanç patrimonial, demonstracão do resultado do exercício ou demonstracão dos lucros ou prejuízos acumulados.

\subsection{Balanço patrimonial (BP)}

Do balanço patrimonial importa saber inicialmente sua definição e natureza jurídica.

De acordo com a Norma Brasileira de Contabilidade NBC-T3, balanço patrimonial é a demonstração contábil destinada a evidenciar, qualitativa e quantitativamente, numa determinada data, o patrimônio e o patrimônio líquido da entidade.

Deve-se ter em conta, porém, que os balanços, como as demais demonstrações financeiras, não são apenas peças contábeis, mas também verdadeiros atos jurídicos consubstanciados em declaração unilateral de vontade da companhia, devidamente aprovados por seus órgãos internos (individuais ou coletivos), a seus sócios, credores, fisco e outros terceiros interessados.

Segundo a magistral lição do Prof. Fábio Konder Comparato: “O balanço é um ato jurídico e não simples ato material. De balanço, a rigor, só se pode falar depois que o titular do patrimônio balanceado - pessoa física ou jurídica - o aprova, obedecidas as formalidades legais. Antes disso, o que há é um projeto ou uma minuta de balanço, sem valor contábil ou existência jurídica. Em se tratando de sociedade anônima, balanço haverá tão-só depois que a assembléia geral de acionistas - regularmente convocada e 
instalada - delibera sua aprovação. Trata-se, aliás, no Direito brasileiro, de um dos atos de competência privativa daquele órgão societário" ${ }^{126}$.

Ocupa-se o balanço de trazer em seu bojo a situação patrimonial da sociedade: reflete o saldo dos lançamentos efetuados em suas contas de ativo, passivo e patrimônio líquido, este último definido pela diferença dos dois primeiros. Além das contas patrimoniais, o balanço traz, no patrimônio líquido, a conta de lucros e prejuízos acumulados que, apurando-se mediante soma algébrica das contas de resultado (soma de grandezas positivas e negativas), faz uma espécie de "ponte" ou "ligação" entre o balanço patrimonial (BP) e a demonstração de resultado do exercício (DRE) ${ }^{127}$.

Tradicionalmente, o balanço é definido graficamente através da inserção das contas representativas do ativo à esquerda do relatório, incluindo aquelas representativas do passivo na parte superior direita e as de patrimônio líquido na parte inferior direita, na forma ilustrada a seguir.

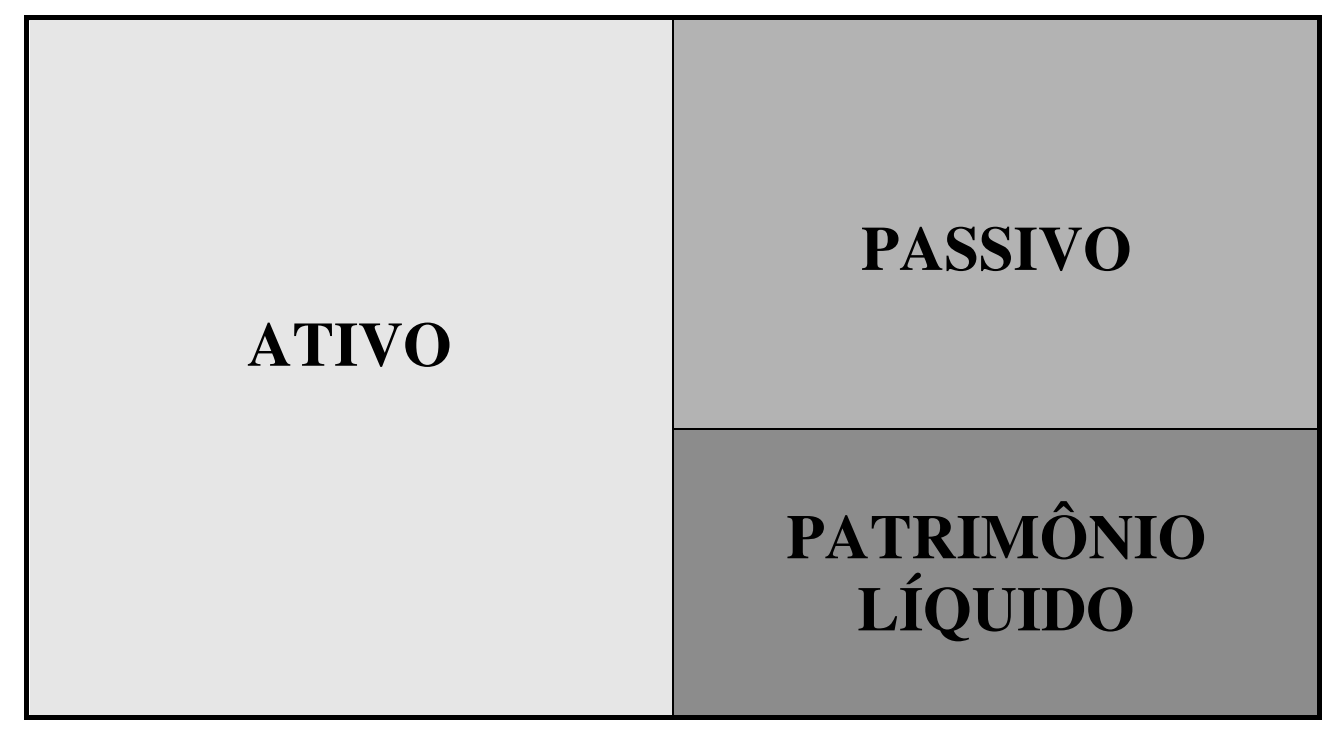

A designação ilustrada acima tem a vantagem de permitir a visualização gráfica do patrimônio líquido, pela diferença ou subtração entre a representação do ativo e do passivo. Não se trata, porém, de forma obrigatória, sendo comuns as publicações que

\footnotetext{
${ }^{126}$ COMPARATO, Fábio Konder. Natureza jurídica do balanço. Ensaios e pareceres de direito empresarial. Rio de Janeiro: Forense, 1978. p. 29.

${ }^{127}$ As normas internacionais de contabilidade (IFRS) regulam a divulgação de fatos relevantes posteriores ao fechamento do balanço.
} 
trazem tais agrupamentos em forma vertical, ou mesmo aquelas que unificam passivo e patrimônio líquido.

Como já se ressaltou neste trabalho, o ativo traduz as contas referentes aos bens e direitos da entidade, o passivo retrata as obrigações respectivas e o patrimônio líquido, as quantias de aporte pelos sócios, os lucros empresariais e as reservas legais ou voluntárias.

Outra forma de se visualizar a mesma realidade consiste em entender o lado direito do balanço, formado pelo passivo e o patrimônio líquido, como origens de recursos, e o lado esquerdo do balanço, representado pelo ativo, como aplicações de recursos.

De fato, nessa perspectiva, o passivo representa as origens de recursos representadas pelo financiamento de terceiros ao desenvolvimento das atividades empresariais, tais como empréstimos, valores a serem pagos pela força de trabalho utilizada, impostos a pagar, etc. Por seu turno, o patrimônio líquido representa o financiamento que os próprios sócios deram à criação da entidade, bem como aquilo que esta obteve de suas atividades. A aplicação dos recursos obtidos de fontes externas (passivos) ou internas (patrimônio líquido) é representada pelo ativo, que consubstancia os bens e direitos em que a entidade empregou os recursos obtidos, destinados à manutenção de seus fins.

Além do saldo dos lançamentos em cada rubrica, o balanço traz em si uma organização interna, consistente na classificação das contas em determinados subgrupos.

Tradicionalmente, nos termos definidos pela Lei n. 6.404/76, as contas de ativo são classificadas em grau decrescente de liquidez, iniciando pelos recursos mais líquidos, representados imediatamente por moeda (contas caixa, aplicações financeiras, etc.) até aqueles menos líquidos (normalmente constantes do ativo imobilizado). Três grandes grupos de contas de ativo são utilizados no balanço, com algumas subdivisões internas, como já salientamos anteriormente: 1) ativo circulante; 2) ativo realizável a longo prazo; 3) ativo permanente (este subdividido em investimentos, imobilizado, intangível e diferido). 
Já o passivo, conforme a legislação supracitada, é classificado em grau decrescente de exigibilidade, iniciando-se pelas rubricas exigíveis em menor espaço de tempo até aquelas exigidas em maior prazo, classificando-se em dois grandes subgrupos: 1) passivo circulante; 2) passivo exigível a longo prazo $^{128}$.

Não se deve confundir balanço com balancete. Na verdade, o balancete consiste em um relatório prévio e antecipatório do balanço, que consiste em arrolar todas as contas utilizadas para efetivar os lançamentos, verificando a correspondência entre os valores lançados a débito e a crédito.

A função principal do balancete é realizar uma prévia verificação dos lançamentos efetuados, antes do levantamento do balanço, para evitar eventuais erros. Hoje, entretanto, com o advento dos mecanismos informatizados, sua função histórica perdeu muito em importância.

Um breve exemplo ilustrará a distinção entre as duas figuras.

Suponhamos uma sociedade limitada que inicia suas atividades no mês de dezembro de 2006, tendo os seguintes fatos econômicos a serem registrados no mês:

Quadro 14: listagem hipotética de fatos econômicos a serem lançados no exemplo referido no texto (desconsiderados alguns lançamentos como depreciação, provisões e etc.)

\begin{tabular}{|c|c|}
\hline Título e data & Valor em R\$ \\
\hline $\begin{array}{c}\text { Formação de capital, } \\
\text { integralização à vista em dinheiro }\end{array}$ & $1.000 .000,00$ \\
\hline Compra de veículos & $100.000,00$ \\
\hline Compra de imóvel & $200.000,00$ \\
\hline Salários e encargos a pagar & $20.000,00$ \\
\hline $\begin{array}{c}\text { Compra de estoques (150 } \\
\text { unidades) }\end{array}$ & $15.000,00$ \\
\hline
\end{tabular}

\footnotetext{
${ }^{128}$ Esse critério não é unânime no Direito Comparado. O Código Civil italiano, por exemplo, classifica o ativo, iniciando com os créditos dos sócios, e o imobilizado (immobilizzazioni), terminando com as disponibilidades líquidas (disponibilità liquide) no ativo circulante.
} 


\begin{tabular}{|c|c|}
\hline $\begin{array}{c}\text { Receita de vendas (venda e metade } \\
\text { das unidades de estoque à vista) }\end{array}$ & $30.000,00$ \\
\hline $\begin{array}{c}\text { Outras despesas operacionais } \\
\text { (pagamento à vista) }\end{array}$ & $5.000,00$ \\
\hline $\begin{array}{c}\text { Impostos incidentes sobre as } \\
\text { vendas (ainda não pagos) }\end{array}$ & $5.400,00$ \\
\hline
\end{tabular}

Ao efetivarmos o balancete, teríamos:

Quadro 15: balancete no final do período mensal

\begin{tabular}{|c|c|c|}
\hline Conta & Débito & Crédito \\
\hline Caixa & $1.030 .000,00$ & $320.000,00$ \\
\hline Veículos & $100.000,00$ & \\
\hline Imóveis & $200.000,00$ & \\
\hline Estoques & $15.000,00$ & $7.500,00$ \\
\hline Provisão para salários e encargos & & $20.000,00$ \\
\hline Impostos a pagar & & $5.400,00$ \\
\hline Receita de vendas & & $30.000,00$ \\
\hline Custo das mercadorias vendidas & $7.500,00$ & \\
\hline Despesas de salários e encargos & $20.000,00$ & \\
\hline Outras despesas operacionais & $5.000,00$ & \\
\hline Despesas de impostos & $5.400,00$ & \\
\hline Capital & & $1.000 .000,00$ \\
\hline Total & $\mathbf{1 . 3 8 2 . 9 0 0 , 0 0}$ & $\mathbf{1 . 3 8 2 . 9 0 0 , 0 0}$ \\
\hline
\end{tabular}

Veja-se que, pela visualização do balancete, podemos constatar que os lançamentos efetuados no período considerado foram feitos corretamente, sob a perspectiva do princípio de partidas dobradas. Os saldos iguais no total indicam que os valores lançados consideraram referido princípio. Não quer dizer, entretanto, que o mérito dos lançamentos esteja correto, pois o balancete não permite, numa primeira análise, a verificação da correção das rubricas utilizadas para os lançamentos, nem mesmo se estes foram completos ou se houve inversão de valores lançados.

Daí por que o balancete, sendo um documento preliminar ao balanço, era utilizado como instrumento de mera verificação formal de erros de lançamento. Servia, basicamente, para evidenciar alguma operação em que não houvesse sido respeitado o postulado de partidas dobradas. 
O balanço para esta mesma situação seria o seguinte:

\section{Quadro 16: balanço no final do período mensal}

\begin{tabular}{|c|c|c|c|}
\hline & 2006 & & 2006 \\
\hline Ativo & & Passivo & \\
\hline Ativo Circulante & & Passivo Circulante & \\
\hline Caixa & $710.000,00$ & $\begin{array}{l}\text { Provisão para salários e } \\
\text { encargos }\end{array}$ & $20.000,00$ \\
\hline Estoques & $7.500,00$ & Impostos a pagar & $5.400,00$ \\
\hline $\begin{array}{l}\text { Total do ativo } \\
\text { circulante }\end{array}$ & $717.500,00$ & $\begin{array}{l}\text { Total do passivo } \\
\text { circulante }\end{array}$ & $25.400,00$ \\
\hline Ativo Permanente & & Patrimônio líquido & \\
\hline Veículos & $100.000,00$ & Capital & $1.000 .000,00$ \\
\hline Imóveis & $200.000,00$ & $\begin{array}{l}\text { Lucros e prejuízos } \\
\text { acumulados }\end{array}$ & $(7.900,00)$ \\
\hline $\begin{array}{l}\text { Total do ativo } \\
\text { permanente }\end{array}$ & $300.000,00$ & $\begin{array}{l}\text { Total do patrimônio } \\
\text { líquido }\end{array}$ & $992.100,00$ \\
\hline Total do ativo & $1.017 .500,00$ & $\begin{array}{l}\text { Total do passivo e } \\
\text { patrimônio líquido }\end{array}$ & 1.017.500,00 \\
\hline
\end{tabular}

Nem sempre a exatidão formal dos números apresentados no balanço detém um rigor tão preciso. Há várias limitações de tal relatório, oriundas principalmente das restrições conceituais da própria ciência da contabilidade, de que trataremos melhor mais adiante.

Como pondera o Prof. Fábio Konder Comparato ${ }^{128 A}$, “Vulgarmente, com efeito, o balanço é concebido como mera reprodução da realidade econômica da empresa, ou como espelho de uma situação patrimonial, no dizer de um autor (Francisco Messineo, Studi di Diritto delle Società, Milão, 1958, pg. 132). A não ser na hipótese de lançamentos falsos ou errôneos, o leigo não entende como se possa retocar essa fotografia do patrimônio. Tal concepção, no entanto, é totalmente imprópria. O balanço, como de resto

128A COMPARATO, Fábio Konder. Op. cit., 1978. p. 31. 
toda a contabilidade, não pode jamais ser um simples reflexo de fatos econômicos, porque se trata de uma interpretação simbólica e, portanto, convencional da realidade. Os fatos econômicos não passam para os livros contábeis no estado bruto, mas são trazidos, simbolicamente, em conceitos e valores; ou seja, não previamente estimados e valorados, segundo um critério determinado e em função de uma finalidade específica. A exatidão matemática dos balanços, que o vulgo contempla admiravelmente, é mera coerência interna e recíproca de lançamentos em partidas dobradas, simples exatidão formal. Mas entre a realidade econômica e sua tradução contábil, interfere, necessariamente, um juízo de valor, uma estimativa axiológica, cuja imprecisão e contestabilidade jamais poderão ser suprimidas, porque inerentes ao próprio processo de conhecimento. A verdade contábil é, pois, simplesmente relativa. O lucro de balanço, por exemplo, é uma realidade meramente contábil e abstrata. A ocorrência de lucros de exploração e seu exato montante, a rigor, só podem ser verificados, realmente, quando a empresa se extingue e se apura o resultado final. 'Profits can never be determined with certainty until a business adventure has been completely liquidated except in the case where the returns have at least exceeded the capital originally invested' (H.R. Hartifield, Accounting. Its principles and problems, Nova York, 1927, p. 254)”.

\subsection{Demonstração do Resultado do Exercício (DRE)}

A Demonstração de Resultados do Exercício (DRE) visa a demonstrar aos usuários da escrituração empresarial como se saiu, ao final de determinado período, a entidade em observação, em relação a suas contas de resultado, além de fornecer ao usuário uma tendência para os resultados futuros da companhia ${ }^{129}$.

\footnotetext{
${ }^{129}$ Justamente por possuir essa característica de predição dos resultados futuros, as normas internacionais de contabilidade (IFRS) exigem que a companhia indique em sua DRE se algum setor ou atividade relevante foi paralisado (descontinuado), apresentando seu resultado separadamente. Isso porque a apresentação conjunta de resultados de operações descontinuadas pode induzir o usuário da demonstração que referida atividade permanecerá em continuidade nos exercícios seguintes, gerando, pois, expectativas de receitas (que, na verdade, já se encerraram). Isso não consta na Lei 6.404/76, muito embora esteja presente no OFÍCIOCIRCULAR/CVM/SNC/SEP $\mathrm{N}^{\circ}$ 01/2005. Também pelo mesmo motivo, as normas internacionais determinam a separação da demonstração por segmentos.
} 
As contas de resultado, as quais passamos anteriormente em breve revista, refletem as receitas e despesas empresariais. Tal conceito, que ao leigo pode significar meramente a entrada e saída de dinheiro do caixa, depende de um exame mais aprofundado.

Isso porque se entende como princípio geral da contabilidade o princípio da competência. Nos termos do que este enuncia, as receitas e despesas devem ser reconhecidas quando da ocorrência do fato gerador respectivo, e não quando de seu pagamento ou recebimento em dinheiro. Assim, em uma venda a prazo, para recebimento, e.g., depois de três meses da contratação, a entidade deverá reconhecer, desde a formalização do contrato, a receita respectiva. Do mesmo modo, após ter se utilizado da força de trabalho de um empregado durante um mês, deverá provisionar em seu passivo os montantes de encargos devidos (férias, décimo terceiro salário, etc.), com o reconhecimento da despesa respectiva, e não deixar para fazê-lo somente quando no pagamento de referidas verbas.

Assim, as receitas (operacionais) são tidas como contrapartidas da atividade de vendas ou prestação de serviços a terceiros, haja ou não recebimento à vista. Do mesmo modo, as despesas são frutos da utilização ou consumo de bens ou serviços, haja ou não o pagamento imediato.

É possível, assim, com a utilização do princípio da competência, a existência de lucro contábil sem qualquer aumento do valor de dinheiro em caixa, bem como a existência de prejuízo contábil com dinheiro em caixa.

A utilização do princípio da competência é de uso obrigatório pelas sociedades anônimas (art. 177 da Lei n. 6.404/76), não havendo tal obrigatoriedade para a as sociedades limitadas e outros tipos societários. Estas, respeitando-se algumas restrições no caso de escrituração fiscal ${ }^{130}$, poderão se utilizar do regime de caixa, para o qual as

\footnotetext{
${ }^{130}$ As normas tributárias contêm alguns princípios inerentes à escrituração fiscal, os quais possibilitam, em determinados casos, a adoção do regime de caixa, ao invés do da competência. Não é o caso de aprofundar aqui o estudo de tais normas, razão pela qual trazemos à luz apenas uma decisão da Receita Federal a respeito: "ACÓRDÃO No 5996 de 23 de abril de 2004 ASSUNTO: Imposto sobre a Renda de Pessoa Jurídica - IRPJ EMENTA: LUCRO PRESUMIDO. REGIME DE CAIXA. A adoção do regime de caixa na apuração do lucro presumido implica, para a pessoa jurídica que mantiver escrituração contábil, na forma da legislação comercial, o controle dos recebimentos de suas receitas em conta específica, na qual, em cada
} 
receitas ou despesas são reconhecidas quando do ingresso ou saída de dinheiro do caixa da entidade.

O resultado final da apuração das contas de resultado nos dará o lucro do período (ou do exercício), cujos valores serão transportados ordinariamente para a conta "lucros e prejuízos acumulados", constante do balanço patrimonial.

As contas de resultado, ao contrário das patrimoniais, têm um período específico e determinado de tempo no qual acumulam valores, normalmente coincidente com o exercício social. A partir de então, seu saldo é transposto para uma conta de apuração, normalmente denominada "apuração do resultado do exercício". A soma algébrica dos valores inseridos nesta última conta nos dará o lucro (ou prejuízo) líquido do exercício.

No exemplo anterior, utilizado para a elaboração do balancete e balanço patrimonial, tínhamos as seguintes contas de resultado.

\section{Quadro 17: contas de resultado (exemplo anterior)}

\begin{tabular}{|c|c|c|}
\hline Conta & Débito & Crédito \\
\hline Receita de vendas & & $30.000,00$ \\
\hline Custo das mercadorias vendidas & $7.500,00$ & \\
\hline Despesas de salários e encargos & $20.000,00$ & \\
\hline Outras despesas operacionais & $5.000,00$ & \\
\hline Despesas de impostos & $5.400,00$ & \\
\hline
\end{tabular}

Para a apuração do resultado do exercício, o saldo de cada uma das contas supracitadas é zerado, através de lançamento a débito (para as contas com lançamento a

\footnotetext{
lançamento, será indicada a nota fiscal a que corresponder o recebimento; não atendido tal requisito, o lucro presumido será apurado da forma convencional, ou seja, com base no regime de competência. LUCRO PRESUMIDO. PRESTAÇÃO DE SERVIÇOS DE CONSTRUÇÃO CIVIL. Na atividade de prestação de serviços de construção civil o percentual aplicável é o de $32 \%$ previsto para as pessoas jurídicas prestadoras de serviços em geral; o percentual de 8\% apenas se aplica quando houver emprego de materiais próprios, assim entendidos os materiais que se incorporam à obra, perdendo a qualidade de bens móveis".
} 
crédito) e a crédito (para as contas lançadas a débito), sendo os valores transferidos para a conta "apuração do resultado do exercício", que ficaria com os seguintes valores.

\section{Quadro 18: apuração do resultado do exercício}

\begin{tabular}{|r|c|}
\hline \multicolumn{1}{|c|}{ Débito } & Crédito \\
\hline $7.500,00$ & $30.000,00$ \\
$20.000,00$ & \\
$5.000,00$ & \\
$5.400,00$ & \\
\hline 37900,00 & $30.000,00$ \\
\hline $7.900,00$ & \\
\hline
\end{tabular}

Ordinariamente, o valor final referente ao lucro ou, como no exemplo, prejuízo do exercício é transportado para a conta "lucros e prejuízos acumulados", componente do balanço patrimonial.

A demonstração do resultado do exercício nada mais é que a tradução, de forma discriminada, estruturada e clara, da conta "apuração do resultado do exercício", na forma estabelecida na legislação societária.

Para as sociedades anônimas, a Lei n. 6.404/76 determina a seguinte estrutura para o demonstrativo em análise:

Art. 187. A demonstração do resultado do exercício discriminará:

I - a receita bruta das vendas e serviços, as deduções das vendas, os abatimentos e os impostos;

II - a receita líquida das vendas e serviços, o custo das mercadorias e serviços vendidos e o lucro bruto;

III - as despesas com as vendas, as despesas financeiras, deduzidas das receitas, as despesas gerais e administrativas, e outras despesas operacionais; 
IV - o lucro ou prejuízo operacional, as receitas e despesas não operacionais; (redação dada pela Lei 9.249 de 26.12.95)

$V$ - o resultado do exercício antes do Imposto sobre a Renda e a provisão para o imposto;

VI - as participações de debêntures, empregados, administradores e partes beneficiárias, e as contribuições para instituições ou fundos de assistência ou previdência de empregados;

VII - o lucro ou prejuízo líquido do exercício e o seu montante por ação do capital social $^{131}$.

Um modelo teórico de demonstração de resultado pode ser visto a seguir ${ }^{132}$ :

\begin{tabular}{|c|c|c|}
\hline DEMONSTRAÇÃO DO RESULTADO DO & 2006 & 2007 \\
\hline $\begin{array}{l}\text { RECEITA BRUTA DE VENDAS } \\
\text { Receitas de vendas de mercadorias } \\
\text { Receitas de prestação de serviços } \\
\text { (-) DEDUÇÕES DE VENDAS } \\
\text { Impostos sobre as vendas } \\
\text { Devoluções de vendas } \\
\text { Descontos Incondicionais } \\
\text { (=) RECEITA LÍQUIDA DE VENDAS } \\
\text { (-) Custo das mercadorias vendidas } \\
\text { (=) LUCRO BRUTO } \\
\text { (-) Despesas com vendas } \\
\text { (-) Despesas administrativas } \\
\text { (-) Despesas financeiras } \\
\text { (+) Receitas financeiras } \\
\text { (+/-) Outras despesas ou receitas operacionais } \\
\text { (=) LUCRO OU PREJUÍZO OPERACIONAL } \\
\text { (+) Receitas não operacionais } \\
\text { Ganhos de capital }\end{array}$ & & \\
\hline
\end{tabular}

${ }^{131}$ As normas internacionais de contabilidade (IFRS) determinam, para melhoria da informação do usuário da DRE, que além do lucro por ação (que se obtém pelo quociente do lucro líquido pelo número de ações), seja também informado o lucro diluído por ação, considerando-se as prováveis conversões de outros títulos e instrumentos de dívida emitidos pela sociedade (tais como opções, debêntures, etc.) em ações, o que fatalmente diluirá o lucro por ação do acionista originário. Isso não consta na Lei n. 6.404/76.

${ }^{132} \mathrm{O}$ modelo é adaptado de SANTOS, José Luiz dos; SCHIMIT, Paulo. Fundamentos de Contabilidade Societária. São Paulo: Atlas, 2005. 


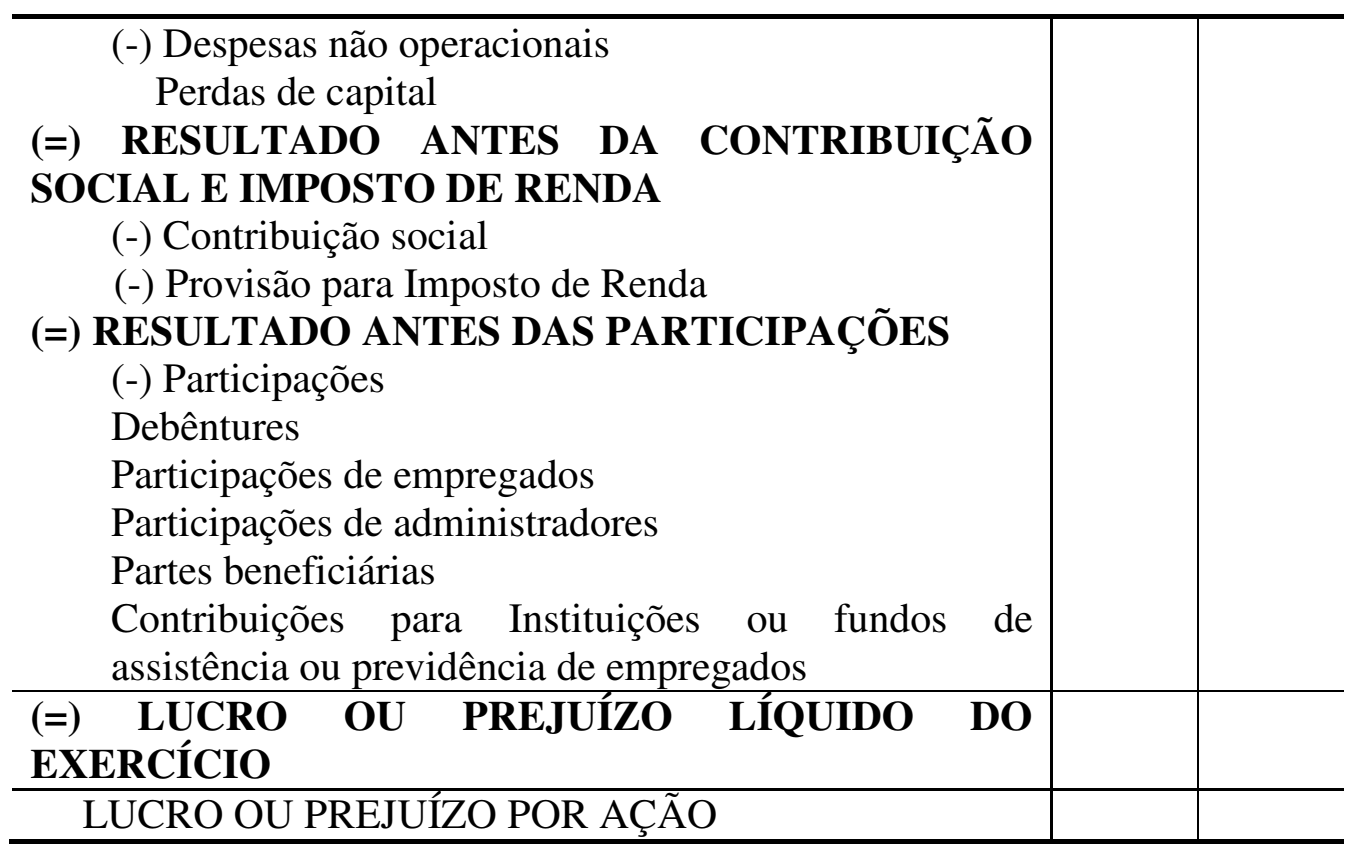

Veja-se que no Direito Comparado há disposições mais complexas, que exigem um maior grau de informação em referido demonstrativo. É o caso do Código Civil italiano (art. 2.425), que determina para a demonstração de resultado (conto economico) a seguinte estrutura:

A. $\quad$ Valore della produzione:

1. $\quad$ ricavi delle vendite e delle prestazioni;

2. variazioni delle rimanenze di prodotti in corso di lavorazione, semilavorati e finiti;

3. variazioni dei lavori in corso su ordinazione;

4. incrementi di immobilizzazioni per lavori interni;

5. altri ricavi e proventi, con separata indicazione dei contributi in conto esercizio.

Totale.

B. Costi della produzione

6. per materie prime, sussidiarie, di consumo e di merci;

7. per servizi;

8. per godimento di beni di terzi;

9. per il personale:

a. salari e stipendi;

b. $\quad$ oneri sociali;

c. trattamento di fine rapporto;

d. $\quad$ trattamento di quiescenza e simili;

e. altri costi;

10. ammortamenti e svalutazioni: 
a. ammortamento delle immobilizzazioni immateriali;

b. ammortamento delle immobilizzazioni materiali;

c. altre svalutazioni delle immobilizzazioni;

d. svalutazioni dei crediti compresi nell'attivo circolante e delle disponibilità liquide;

11. variazioni delle rimanenze di materie prime, sussidiarie, di consumo e merci;

12. accantonamenti per rischi;

13. altri accantonamenti;

14. oneri diversi di gestione.

Totale.

Differenza tra valore e costi della produzione $(A-B)$.

C. Proventi e oneri finanziari:

15. proventi da partecipazioni, con separata indicazione di quelli relativi ad imprese controllate e collegate;

16. altri proventi finanziari;

a. $\quad$ da crediti iscritti nelle immobilizzazioni, con separata indicazione di quelli da imprese controllate e collegate e di quelli da controllanti;

b. da titoli iscritti nelle immobilizzazioni che non costituiscono partecipazioni;

c. da titoli iscritti nell'attivo circolante che non costituiscono partecipazioni;

d. proventi diversi dai precedenti, con separata indicazione di quelli da imprese controllate $e$ collegate e di quelli da controllanti;

17. interessi e altri oneri finanziari, con separata indicazione di quelli verso imprese controllate e collegate e verso controllanti.

Totale (15-16-17).

D. Rettifiche di valore di attività finanziaria:

18. rivalutazioni:

a. di partecipazioni;

b. di immobilizzazioni finanziarie che non costituiscono partecipazioni;

c. di titoli iscritti all'attivo circolante che non costituiscono partecipazioni.

19. svalutazioni: 

a. di partecipazioni;
b. di immobilizzazioni finanziarie che non costituiscono partecipazioni;
c. di titoli iscritti nell'attivo circolante che non costituiscono partecipazioni.

\section{Totale delle rettifiche (18-19).}

E. Proventi e oneri straordinari:

20. proventi, con separata indicazione delle plusvalenze da alienazioni i cui ricavi non sono iscrivibili al n. 5;

21. oneri, con separata indicazione delle minusvalenze da alienazioni i cui effetti contabili non sono iscrivibili al $n .14$ e delle imposte relative a esercizi precedenti.

Totale delle partite straordinarie (20-21).

\section{Risultato prima delle imposte $(A-B+-C+-D+-E)$;}

22. imposte sul reddito dell'esercizio;

23. (risultato dell'esercizio);

24. (rettifiche di valore operate esclusivamente in applicazione di norme tributarie);

25. (accantonamenti operati esclusivamente in applicazione di norme tributarie);

26. utile (perdita) dell'esercizio

Em nosso exemplo prático, muito embora não tenhamos nele todas as rubricas referidas no artigo anteriormente citado, exibiríamos a seguinte demonstração:

\section{Quadro 19: demonstração do resultado do exercício de 2006}

\begin{tabular}{|lrr|}
\hline Receita operacional bruta & $30.000,00$ \\
(-) Impostos & $(5.400,00)$ \\
(=) Receita operacional líquida & $\begin{array}{r}24.600,00 \\
(7.500,00)\end{array}$ \\
$\begin{array}{l}\text { (-) Custo das mercadorias vendidas } \\
\text { (=) Lucro Bruto }\end{array}$ & $17.100,00$ \\
(-) Despesas operacionais & & \\
Salários e encargos & $20.000,00$ & \\
Outras despesas operacionais & $5.000,00$ & $(25.000,00)$ \\
(=) Prejuízo do período & & $(7.900,00)$ \\
\hline
\end{tabular}


Uma breve análise do demonstrativo acima permite visualizar alguns fenômenos econômicos importantes em relação à entidade observada. Pode-se verificar que, tendo prejuízo contábil, este derivou em grande parte dos salários e encargos, que compõem $66,67 \%$ da receita bruta. Sua margem bruta de lucro em cada produto vendido foi de aproximadamente $70 \%$, resultado da divisão do lucro bruto pela receita operacional líquida.

\subsection{Demonstração do Fluxo de Caixa (DFC)}

Essa demonstração passou a ser exigida na legislação de sociedades anônimas com o advento da Lei n. 11.638/07, que, ao dar nova redação ao art. 176, IV, veio a substituir a antiga demonstração de origens e aplicações de recursos (DOAR).

Como já salientamos algumas vezes, a existência de lucros, sob o ponto de vista contábil não garante, por si só, que a entidade em análise tenha obtido sucesso ou fracasso em sua atividade empresarial.

De fato, o princípio da competência faz com que se lancem como receitas alguns fatos econômicos que ainda não repercutiram no caixa da entidade, bem como exige o lançamento, como despesa, de operações que não exigiram qualquer desembolso monetário.

Além disso, há fatos que são considerados como componentes do resultado contábil que não operam qualquer efeito nas disponibilidades financeiras líquidas da entidade, mas que poderão ter intenso reflexo no resultado empresarial. Alguns exemplos disso são a depreciação (contabilizada como redução de ativo em contrapartida de despesa, diminuindo o lucro) e as provisões (inseridas de forma idêntica).

Alexandre Povoa, em excelente obra sobre avaliação de empreendimentos e precificação de ações, ressalta que "A primeira pergunta lógica que vem à cabeça de 
qualquer um é acerca do porquê da projeção de fluxo de caixa de uma empresa. Por que não utilizarmos os lucros diretamente? Normalmente, o cidadão comum associa imediatamente o lucro ao sucesso ou fracasso de uma companhia. Se a empresa 'deu prejuízo' normalmente é sinal de fracasso. Conforme já observamos, a contabilidade é recheada de regras que acabam, muitas vezes, distorcendo a verdadeira realidade de uma empresa. Não estamos nem considerando fatos excepcionais como as fraudes contábeis que eclodiram em 2002 e 2003 em grandes empresas mundiais, como a WorldCom, Enron, Vivendi e Parmalat. Neste caso, os executivos destas empresas esconderam passivos e inflaram propositadamente ativos. Estamos alertando para o fato de que princípios contábeis mundialmente aceitos podem não ajudar a refletir o que foi realmente o desempenho de uma empresa em determinado período (...) Portanto, o que mais importa no processo de precificação é mensurar a capacidade de geração de caixa de uma empresa. O que a empresa vai fazer com o caixa gerado é uma questão mais subjetiva, que dependerá de boa ou má administração" ${ }^{\text {133. }}$.

Verifica-se, portanto, a importância de se saber em detalhes como se opera o fluxo de caixa daquele que exerce a empresa, uma vez que a saúde financeira do empreendimento e até mesmo seu valor de mercado dependem de sua capacidade de gerar caixa $^{134}$.

A Lei n. 11.638/07, ao conferir nova redação à Lei n. 6.404/76, não especificou a metodologia para realização de tal demonstração, preceituando apenas, na redação do art. 188, que esta deve conter, no mínimo: as alterações ocorridas, durante o exercício, no saldo de caixa e equivalentes de caixa, segregando-se essas alterações em, no mínimo, 3 (três) fluxos: a) das operações; b) dos financiamentos; e c) dos investimentos.

$\mathrm{Na}$ doutrina contábil e respectivas normas internacionais, preceituam-se dois métodos para a elaboração da DFC: o direto e o indireto, como veremos a seguir. Isso

\footnotetext{
${ }^{133}$ POVOA, Alexandre. Valuation. Como precificar ações. São Paulo: Globo, 2004. p. 114.

${ }^{134}$ Resta praticamente pacífico entre doutrinadores, investidores e operadores de mercado, que o método mais confiável e utilizado para a avaliação do valor de mercado de um empreendimento é o sistema de fluxo (líquido) de caixa descontado. Tal metodologia, em suma, consiste na previsão futura dos fluxos de caixa empresariais líquidos, conforme os cenários econômicos prováveis (gerais e específicos), para um período ulterior e perpetuamente. Tais valores de fluxo de caixa são trazidos a valor presente, descontando-se seu montante por uma taxa normalmente correspondente ao custo médio ponderado de capital (CMPC ou WACC - weighted average cost of capital), consistente no custo ponderado entre capital de terceiros e próprio.
} 
tem base principal em normas internacionais editadas pelo FASB (Financial Accounting Standards Board) e do IASB (International Accounting Standards Board) ${ }^{135}$.

Para fins da DFC, entende-se como caixa não só as quantias disponíveis em dinheiro em posse da entidade, mas também aqueles recursos de liquidez imediata, como as aplicações financeiras que possuam tal característica (equivalentes de caixa). Trata-se, pois, de uma demonstração das disponibilidades e não somente do caixa propriamente dito.

Façamos um exemplo prático, aproveitando o que já foi elaborado anteriormente para o balanço patrimonial e demonstração de resultado.

Suponhamos que, no exercício de 2007, a entidade mencionada anteriormente tivesse que lançar os seguintes fatos econômicos:

Quadro 20: fatos ocorridos no exercício de 2007

\begin{tabular}{|c|c|}
\hline Título e data & Valor em R\$ \\
\hline $\begin{array}{c}\text { Depreciação de veículos e imóveis } \\
\text { (taxa de 5\% a.a.) }\end{array}$ & $15.000,00$ \\
\hline Aumento de capital em dinheiro & $100.000,00$ \\
\hline Empréstimo & $50.000,00$ \\
\hline Salários e encargos a pagar & $10.000,00$ \\
\hline $\begin{array}{c}\text { Compra de estoques (450 } \\
\text { unidades) }\end{array}$ & $45.000,00$ \\
\hline $\begin{array}{c}\text { Despesas de salários e encargos } \\
\text { (pagas) }\end{array}$ & $240.000,00$ \\
\hline $\begin{array}{c}\text { Venda de metade das unidades de } \\
\text { estoque a prazo, para pagamento } \\
\text { no exercício seguinte }\end{array}$ & $60.000,00$ \\
\hline $\begin{array}{c}\text { Venda de metade das unidades de } \\
\text { estoque à vista }\end{array}$ & $60.000,00$ \\
\hline $\begin{array}{c}\text { Pagamento de salários, encargos e } \\
\text { impostos do exercício anterior }\end{array}$ & $25.400,00$ \\
\hline $\begin{array}{c}\text { Outras despesas operacionais } \\
\text { (pagamento à vista) }\end{array}$ & $50.000,00$ \\
\hline
\end{tabular}

\footnotetext{
${ }^{135}$ A Secretaria da Receita Federal tem se utilizado do documento em estudo para a imposição de tributos. Verifique-se a seguinte decisão: “ACÓRDÃO No 2808 de 20 de fevereiro de 2003. ASSUNTO: Imposto sobre a Renda de Pessoa Jurídica - IRPJ. EMENTA: OMISSÃO DE RECEITAS - Excesso de dispêndios em relação aos recursos, apurado através de elaboração da 'Demonstração de Fluxo de Caixa', é passível de lançamento como omissão de receitas. Sendo apresentados na impugnação novos elementos provando que não houve a ocorrência do fluxo negativo, cabe a exoneração do lançamento. AUTOS REFLEXOS - PIS COFINS - IRRF-CSLL - O decidido no mérito do IRPJ, em decorrência de omissão de receitas, repercute na tributação reflexa, exonerando-se os lançamentos".
} 
\begin{tabular}{c|c}
\hline $\begin{array}{c}\text { Impostos incidentes sobre as } \\
\text { vendas (ainda não pagos) }\end{array}$ & $21.600,00$ \\
\hline
\end{tabular}

Se elaborássemos o balanço da entidade supracitada, comparando os exercícios de 2006 e 2007, teríamos:

Quadro 21: balanço dos exercícios de 2006 e 2007

\begin{tabular}{|c|c|c|c|c|c|}
\hline & 2006 & 2007 & & 2006 & 2007 \\
\hline Ativo & & & Passivo & & \\
\hline $\begin{array}{l}\text { Ativo } \\
\text { Circulante }\end{array}$ & & & Passivo Circulante & & \\
\hline Caixa & $710.000,00$ & $559.600,00$ & $\begin{array}{l}\text { Provisão para salários } \\
\text { e encargos }\end{array}$ & $20.000,00$ & $10.000,00$ \\
\hline Clientes & & $60.000,00$ & Empréstimos & - & $50.000,00$ \\
\hline Estoques & $7.500,00$ & & Impostos a pagar & $5.400,00$ & $21.600,00$ \\
\hline $\begin{array}{l}\text { Total do ativo } \\
\text { circulante }\end{array}$ & $717.500,00$ & $619.600,00$ & $\begin{array}{l}\text { Total do passivo } \\
\text { circulante }\end{array}$ & $25.400,00$ & $81.600,00$ \\
\hline $\begin{array}{l}\text { Ativo } \\
\text { Permanente }\end{array}$ & & & Patrimônio líquido & & \\
\hline Veículos & $100.000,00$ & $100.000,00$ & Capital & $1.000 .000,00$ & $1.100 .000,00$ \\
\hline Imóveis & $200.000,00$ & $200.000,00$ & $\begin{array}{l}\text { Lucros e prejuízos } \\
\text { acumulados }\end{array}$ & $(7.900,00)$ & $(277.000,00)$ \\
\hline $\begin{array}{l}\text { Depreciação } \\
\text { acumulada }\end{array}$ & - & $(15.000,00)$ & $\begin{array}{l}\text { Total do patrimônio } \\
\text { líquido }\end{array}$ & $992.100,00$ & $823.000,00$ \\
\hline $\begin{array}{l}\text { Total do ativo } \\
\text { permanente }\end{array}$ & $300.000,00$ & $285.000,00$ & & & \\
\hline Total do ativo & $1.017 .500,00$ & $904.600,00$ & $\begin{array}{l}\text { Total do passivo e } \\
\text { patrimônio líquido }\end{array}$ & $1.017 .500,00$ & $904.600,00$ \\
\hline
\end{tabular}

A demonstração do resultado dos exercícios seria:

Quadro 22: demonstração de resultados dos exercícios de 2006 e 2007

\begin{tabular}{|c|c|c|}
\hline & 2006 & 2007 \\
\hline Receita operacional bruta & $30.000,00$ & $120.000,00$ \\
\hline (-) Impostos sobre vendas & $(5.400,00)$ & $(21.600,00)$ \\
\hline (=) Receita operacional líquida & $24.600,00$ & $98.400,00$ \\
\hline (-) Custo das mercadorias vendidas & $(7.500,00)$ & $(52.500,00)$ \\
\hline (=) Lucro Bruto & $17.100,00$ & $45.900,00$ \\
\hline \multicolumn{3}{|l|}{ (-) Despesas operacionais } \\
\hline Depreciação & & \\
\hline Salários e encargos & & \\
\hline
\end{tabular}


\begin{tabular}{|lrrr|}
$\begin{array}{l}\text { Outras despesas } \\
\text { operacionais }\end{array}$ & $50.000,00$ & $\frac{(315.000,00)}{(25.000,00)}$ \\
$(=)$ Prejuízo do exercício & & $\frac{(2.900,00)}{(269.100,00)}$ \\
\hline
\end{tabular}

Como podemos verificar, o caixa diminuiu seu valor de 2006 para 2007, indo de $\mathrm{R} \$ 710.000,00$ a $\mathrm{R} \$ 559.600,00$, uma diferença negativa de $\mathrm{R} \$ 150.400,00$.

A função da demonstração do fluxo de caixa é justamente demonstrar, em relatório, quais as causas de referida variação.

Como salientamos, dois são os métodos para a elaboração da DFC: o direto e o indireto.

A divergência entre esses dois métodos se encontra na forma de demonstrar os valores recebidos em caixa oriundos das atividades operacionais. Em ambos os métodos, as atividades de investimento (relativas a participações em outras empresas, imobilizado, etc.) ou financiamento (inerentes a empréstimos, venda de ações, pagamento de dividendos, etc.) continuam demonstradas da mesma forma em ambos.

No método direto, observam-se as movimentações das disponibilidades (caixa e equivalentes), apresentando-se nas atividades operacionais todos os itens (pagamentos e recebimentos) que tenham provocado alterações (entradas e saídas) nas primeiras. No exemplo aqui formulado, provocaram entrada no caixa a receita de vendas recebida à vista dos clientes, o pagamento pela compra de estoques, salários, impostos e outras despesas.

Já no método indireto, também chamado de método de reconciliação, partese do lucro ou prejuízo do período, fazendo os ajustes necessários em relação àquelas contas de resultado que não afetam o disponível (e.g., conta de despesa de depreciação). A seguir, apresentam-se as variações das contas de ativo circulante e realizável a longo prazo, adicionando ou subtraindo seu valor, conforme tenham efeito positivo ou negativo sobre as disponibilidades. 
No exemplo prático anteriormente citado, teríamos a seguinte demonstração de fluxo de caixa.

Quadro 23: demonstração de fluxo de caixa em 2007

\begin{tabular}{|c|c|c|c|}
\hline \multicolumn{2}{|c|}{ Método direto } & \multicolumn{2}{|c|}{ Método indireto } \\
\hline Atividades operacionais & & Atividades operacionais & \\
\hline \multicolumn{4}{|l|}{ Recebimentos } \\
\hline de clientes & $60.000,00$ & $\begin{array}{l}\text { Prejuízo Líquido } \\
\text { (+) Depreciação }\end{array}$ & $\begin{array}{r}(269.100,00) \\
15.000,00\end{array}$ \\
\hline Pagamentos & & (-) Variação de Clientes & $(60.000,00)$ \\
\hline a fornecedores & $(45.000,00)$ & (+) Variação de estoques & $7.500,00$ \\
\hline de salários e encargos & $(260.000,00)$ & $\begin{array}{l}\text { (-) Variação de provisão para } \\
\text { salários e encargos }\end{array}$ & $(10.000,00)$ \\
\hline $\begin{array}{l}\text { de outras despesas } \\
\text { operacionais }\end{array}$ & $(50.000,00)$ & $\begin{array}{l}\text { (-) Variação de impostos a } \\
\text { pagar }\end{array}$ & $16.200,00$ \\
\hline de impostos & $(5.400,00)$ & & \\
\hline $\begin{array}{l}\text { Caixa líquido de atividades } \\
\text { operacionais }\end{array}$ & $(300.400,00)$ & $\begin{array}{l}\text { Caixa líquido de atividades } \\
\text { operacionais }\end{array}$ & $(300.400,00)$ \\
\hline Atividades de investimento & & Atividades de investimento & \\
\hline $\begin{array}{l}\text { Atividades de } \\
\text { financiamento }\end{array}$ & & $\begin{array}{l}\text { Atividades de } \\
\text { financiamento }\end{array}$ & \\
\hline Aumento de capital & $100.000,00$ & Aumento de capital & $100.000,00$ \\
\hline Empréstimo de curto prazo & $50.000,00$ & Empréstimo de curto prazo & $50.000,00$ \\
\hline $\begin{array}{l}\text { Caixa líquido de atividades } \\
\text { de financiamento }\end{array}$ & $150.000,00$ & $\begin{array}{l}\text { Caixa líquido de atividades } \\
\text { de financiamento }\end{array}$ & $150.000,00$ \\
\hline $\begin{array}{l}\text { Variação nas } \\
\text { disponibilidades }\end{array}$ & $(150.400,00)$ & $\begin{array}{l}\text { Variação nas } \\
\text { disponibilidades }\end{array}$ & $(150.400,00)$ \\
\hline $\begin{array}{l}\text { (+) Saldo de } \\
\text { disponibilidades em } 2006\end{array}$ & $710.000,00$ & $\begin{array}{l}\text { (+) Saldo de } \\
\text { disponibilidades em } 2006\end{array}$ & $710.000,00$ \\
\hline $\begin{array}{l}\text { (=) Saldo de } \\
\text { disponibilidades em } 2007\end{array}$ & $559.600,00$ & $\begin{array}{l}\text { (=) Saldo de } \\
\text { disponibilidades em } 2007\end{array}$ & $559.600,00$ \\
\hline
\end{tabular}

Pode-se verificar que não há atividades de investimento (ligadas em regra a operações no ativo permanente) no exemplo. Por sua vez, as atividades de financiamento foram obtidas dos sócios (aumento de capital) e de terceiros (empréstimo de curto prazo constante do passivo circulante).

Em relação às atividades operacionais, pode-se perceber a diferença entre as duas demonstrações. O método direto evidencia as atividades operacionais que influenciaram as disponibilidades através da demonstração simples dos pagamentos e 
recebimentos havidos, enquanto o indireto parte do lucro ou prejuízo para demonstrar as variações ocorridas.

\subsection{Demonstração de Mutações no Patrimônio Líquido e de Lucros e Prejuízos Acumulados (DMPL e DLPA)}

A demonstração de mutações no patrimônio líquido e a demonstração de lucros e prejuízos acumulados são relatórios verdadeiramente complementares, por vezes excludentes entre si. Na verdade, a DLPA é parte da DMPL, estando nela incluída, como veremos a seguir.

Por tal motivo, a Lei n. 6.404/76, no $\S 2^{\circ}$ do art. 186, ressalta (grifos nossos):

Art. 186. A demonstração de lucros ou prejuízos acumulados discriminará:

I - o saldo do início do período, os ajustes de exercícios anteriores e a correção monetária do saldo inicial;

II - as reversões de reservas e o lucro líquido do exercício;

III - as transferências para reservas, os dividendos, a parcela dos lucros incorporada ao capital e o saldo ao fim do período.

$\S 1^{\circ}$ Como ajustes de exercícios anteriores serão considerados apenas os decorrentes de efeitos da mudança de critério contábil, ou da retificação de erro imputável a determinado exercício anterior, e que não possam ser atribuídos a fatos subseqüentes. 
$\S 2^{\circ}$ A demonstração de lucros ou prejuízos acumulados deverá indicar o montante do dividendo por ação do capital social e poderá ser incluída na demonstracão das mutacões do patrimônio líquido, se elaborada $e$ publicada pela companhia.

Como bem salientam Iudícibus et al. em relação à demonstração das mutações do patrimônio líquido, "Logicamente, se a empresa elaborar tal demonstração, incluindo-a como integrante de suas Demonstrações Financeiras do exercício, deverá deixar de elaborar a Demonstração de Lucros ou Prejuízos Acumulados, desde que as informações desta estejam incluídas, no mesmo nível de informação, naquela. Para tanto, uma das colunas da demonstração será a da conta Lucros ou Prejuízos Acumulados”"136.

Sem prejuízo, a Instrução n. 59/86 da CVM obriga as companhias abertas a elaborar a DMPL nos seguintes termos:

1. Art. $1^{o}$ - As companhias abertas deverão elaborar e publicar, como parte integrante de suas demonstrações financeiras, a demonstração das mutações do patrimônio líquido, referida ao artigo 186, $\S 2^{\circ}$ "in fine”, da Lei no 6.404, de 15 de dezembro de 1976.

O modelo para elaboração da DMPL de uso sugerido é descrito a seguir.

Quadro 24: modelo de DMPL dado pela Instrução n. 59/86 - CVM

\begin{tabular}{|c|c|c|c|c|c|c|c|c|c|c|}
\hline & \multicolumn{2}{|c|}{$\begin{array}{c}\text { Capital } \\
\text { realizado } \\
\text { atualizado }\end{array}$} & \multicolumn{3}{|c|}{ Reservas de capital } & \multicolumn{2}{|c|}{$\begin{array}{l}\text { Reservas de } \\
\text { reavaliação }\end{array}$} & \multirow{2}{*}{$\begin{array}{c}\text { Reservas } \\
\text { de } \\
\text { lucros } \\
\text { (detalhes } \\
\text { no } \\
\text { quadro } \\
\text { abaixo) }\end{array}$} & \multirow[b]{2}{*}{$\begin{array}{c}\text { Lucros } \\
\text { acumu- } \\
\text { lados }\end{array}$} & \multirow[b]{2}{*}{ Total } \\
\hline & $\begin{array}{c}\text { Capital } \\
\text { subs- } \\
\text { crito }\end{array}$ & $\begin{array}{c}\text { A } \\
\text { rea- } \\
\text { lizar }\end{array}$ & $\begin{array}{l}\text { Corr- } \\
\text { eção } \\
\text { mone- } \\
\text { tária }\end{array}$ & $\begin{array}{l}\text { Ágio } \\
\text { na } \\
\text { subs- } \\
\text { crição }\end{array}$ & $\begin{array}{l}\text { Ações } \\
\text { em } \\
\text { tesou- } \\
\text { raria }\end{array}$ & $\begin{array}{c}\text { Sub- } \\
\text { venção } \\
\text { p/ } \\
\text { inves- } \\
\text { timento }\end{array}$ & $\begin{array}{c}\text { De } \\
\text { ativos } \\
\text { pró- } \\
\text { prios }\end{array}$ & & & \\
\hline $\begin{array}{l}\text { Saldos em } \\
/ /\end{array}$ & & & & & & & & & & \\
\hline $\begin{array}{l}\text { Ajuste de } \\
\text { exercícios }\end{array}$ & & & & & & & & & & \\
\hline
\end{tabular}

${ }^{136}$ IUDÍCIBUS, Sérgio de; MARTINS, Eliseu; GELBCKE, Ernesto Rubens. Op. cit., 2003. p. 376. 


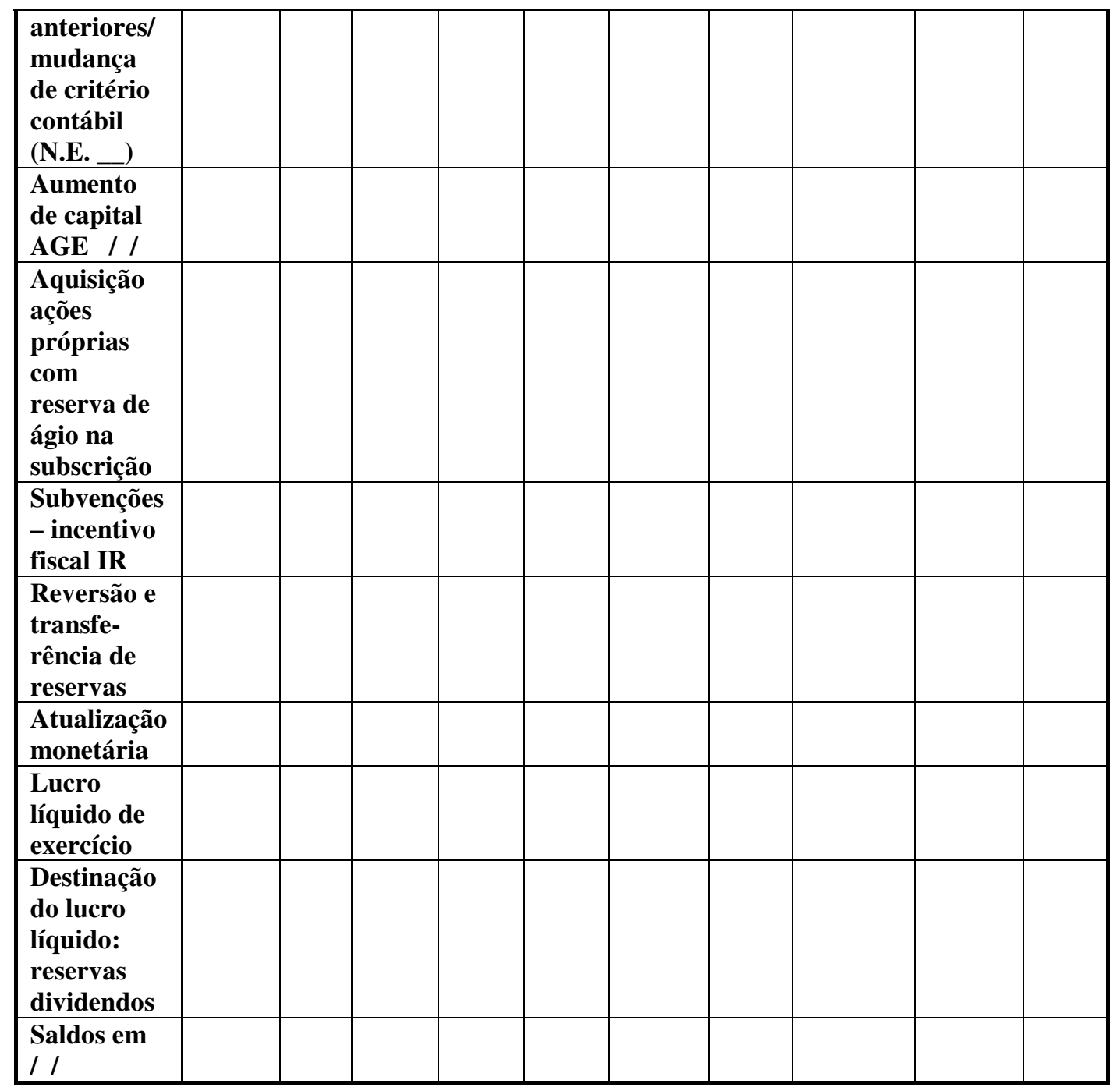

Quadro 25: continuação do modelo de DMPL dado pela Instrução n. 59/86 - CVM

\begin{tabular}{|l|l|l|l|l|l|}
\hline & \multicolumn{5}{|c|}{ Reservas de lucros } \\
\cline { 2 - 6 } & Legal & Estatutária & $\begin{array}{c}\text { Lucros a } \\
\text { realizar }\end{array}$ & $\begin{array}{c}\text { Retenção } \\
\text { p/ } \\
\text { expansão }\end{array}$ & Soma \\
\hline Saldos em / / & & & & & \\
\hline $\begin{array}{l}\text { Reversão para } \\
\text { lucros acumulados }\end{array}$ & & & & & \\
\hline $\begin{array}{l}\text { Atualização } \\
\text { monetária }\end{array}$ & & & & & \\
\hline $\begin{array}{l}\text { Destinação de parte } \\
\text { do lucro líquido }\end{array}$ & & & & & \\
\hline Saldos em / / & & & & & \\
\hline
\end{tabular}


A coluna da esquerda, juntamente com a coluna Lucros Acumulados, no penúltimo quadro, representará a Demonstração de Lucros e Prejuízos Acumulados, que terá basicamente a seguinte estrutura.

\section{Quadro 26: Demonstração de Lucros e Prejuízos Acumulados}

\begin{tabular}{|l|c|}
\hline & $\begin{array}{c}\text { Lucros ou } \\
\text { Prejúzos } \\
\text { acumulados }\end{array}$ \\
\hline Saldos em / / & \\
\hline $\begin{array}{l}\text { Ajuste de exercícios anteriores } \\
\text { mudança de critério contábil (N.E. __) }\end{array}$ & \\
\hline Aumento de capital AGE / / & \\
\hline $\begin{array}{l}\text { Aquisição ações próprias com reserva de ágio } \\
\text { na subscrição }\end{array}$ & \\
\hline Subvenções - incentivo fiscal IR & \\
\hline Reversão e transferência de reservas & \\
\hline Atualização monetária & \\
\hline Lucro líquido de exercício & \\
\hline $\begin{array}{l}\text { Destinação do lucro líquido: } \\
\text { reservas } \\
\text { dividendos }\end{array}$ & \\
\hline Saldos em / / & \\
\hline
\end{tabular}

Poderíamos elaborar a DMPL (com a DLPA incluída) para o exemplo com o qual trabalhamos nas demonstrações anteriores. Obviamente, não tivemos nele uma sociedade anônima e, portanto, a contabilização de vários itens constantes do modelo usado pela CVM (reservas legais, de capital, etc.). No entanto, a elaboração de tais relatórios pode ser feita, ainda que com maior simplicidade, por todas as sociedades, mesmo que não se configurem como sociedades anônimas.

\section{Quadro 27: Demonstração de Lucros e Prejuízos Acumulados (conforme exemplo anterior)}

\begin{tabular}{|c|c|c|c|}
\hline & Capital & $\begin{array}{c}\text { Lucros e } \\
\text { prejuízos } \\
\text { acumulados }\end{array}$ & Total \\
\hline $\begin{array}{c}\text { Saldo em } \\
\mathbf{3 1 . 1 2 . 2 0 0 6}\end{array}$ & $1.000 .000,00$ & $(7.900,00)$ & $992.100,00$ \\
\hline $\begin{array}{c}\text { Aumento de } \\
\text { Capital }\end{array}$ & $100.000,00$ & & $100.000,00$ \\
\hline
\end{tabular}




\begin{tabular}{|c|c|c|c|}
\hline $\begin{array}{c}\text { Lucro líquido } \\
\text { do exercício }\end{array}$ & (269.100,00) & (269.100) \\
\hline $\begin{array}{c}\text { Destinação do } \\
\text { lucro líquido }\end{array}$ & - & - & - \\
\hline $\begin{array}{c}\text { Saldos em } \\
\mathbf{3 1 . 1 2 . 2 0 0 7}\end{array}$ & $1.100 .000,00$ & $(277.000)$ & $823.000,00$ \\
\hline
\end{tabular}

Podemos verificar na demonstração acima como se modificou o patrimônio líquido da entidade analisada, constatando primeiramente que o aporte de capital dos sócios ( $\mathrm{R}$ \$ 100.000,00) não foi suficiente para cobrir o prejuízo das operações (R\$ 269.100,00). O patrimônio líquido como um todo teve uma queda de $\mathrm{R} \$ 169.100,00$ de 2006 para 2007, sendo que seria maior ainda caso não houvesse o aporte de capital.

\subsection{Demonstração de Origens e Aplicações de Recursos (DOAR)}

Essa demonstração não é mais exigida pela Lei n. 6.404/07, uma vez que a Lei n. 11.638/07, dando nova redação ao art. 176, IV, da primeira, veio a substituí-la pela demonstração de fluxo de caixa (DFC). Por interesse histórico, entretanto, decidimos manter referido capítulo, uma vez que ainda poderá haver publicações do gênero pelas companhias, com o conseqüente interesse do usuário em decifrar seu significado.

Para manter suas atividades, é necessário que o empreendedor mantenha certo nível de ativos (ou de capital) voltados a esse fim. O "giro" empresarial, consistente naquelas tarefas de curto prazo que correspondem a um ciclo de operações que inclui, como salientado anteriormente: 1) aquisição de mercadorias, matéria-prima ou insumos de fornecedores (seja para revenda, transformação ou utilização na prestação de serviços); 2) venda das mercadorias ou prestação de serviços, 3) transformação da mercadoria em dinheiro (caixa) ou valores a receber (clientes); 4) pagamento aos fornecedores com nova aquisição de mercadorias, insumos ou matérias-primas. 
Dessa forma, é necessário que se mantenha certo montante em dinheiro para pagamento de contas, uma quantidade determinada de estoque para fazer frente à demanda, entre outras necessidades inerentes ao giro comercial da empresa.

Por outro lado, o ciclo de operações envolve obrigações várias, como o pagamento de fornecedores, empregados, impostos, etc.

Daí por que é sempre necessário que a entidade possua certa liquidez em seus ativos, ou seja, que possa ter condições de, rapidamente, lidar com necessidades imediatas de seu ciclo operacional.

Os recursos (ou o capital) que a entidade destina a esses fins, ou seja, aqueles necessários para financiar seus gastos durante seu ciclo produtivo, recebem a denominação capital de giro.

Mas, como o ciclo produtivo envolve também obrigações, é necessário que se verifique se a entidade possui ativos considerados líquidos (circulantes) em montante superior a seus passivos na mesma condição (passivos circulantes). A diferença entre os ativos e passivos circulantes é denominada capital de giro líquido (CGL) ou capital circulante líquido (CCL).

Salienta Lawrence J. Gitman que, "De forma geral, quanto maior a margem pela qual os ativos circulantes de uma empresa cobrem suas obrigações a curto prazo (passivos circulantes), tanto mais apta ela estará para pagar suas contas nos vencimentos. Essa relação resulta do fato de que a conversão de ativos circulantes, de estoques para duplicatas a receber e destas para caixa, provê os recursos necessários para pagamento das obrigações correntes, as quais representam o uso de caixa"137.

Uma outra forma de se definir o capital circulante líquido é defini-lo como aquela parcela do ativo circulante que é financiada pelo passivo a longo prazo (ou não circulante). Se visualizarmos a estrutura do balanço patrimonial, poderemos verificar

${ }^{137}$ GITMAN, Lawrence J. Princípios de administração financeira. São Paulo: Harbra, 1997. p. 619. 
exatamente referida situação, através da observação dos ativos e passivos circulantes e não circulantes. As representações gráficas a seguir melhor definirão as hipóteses.

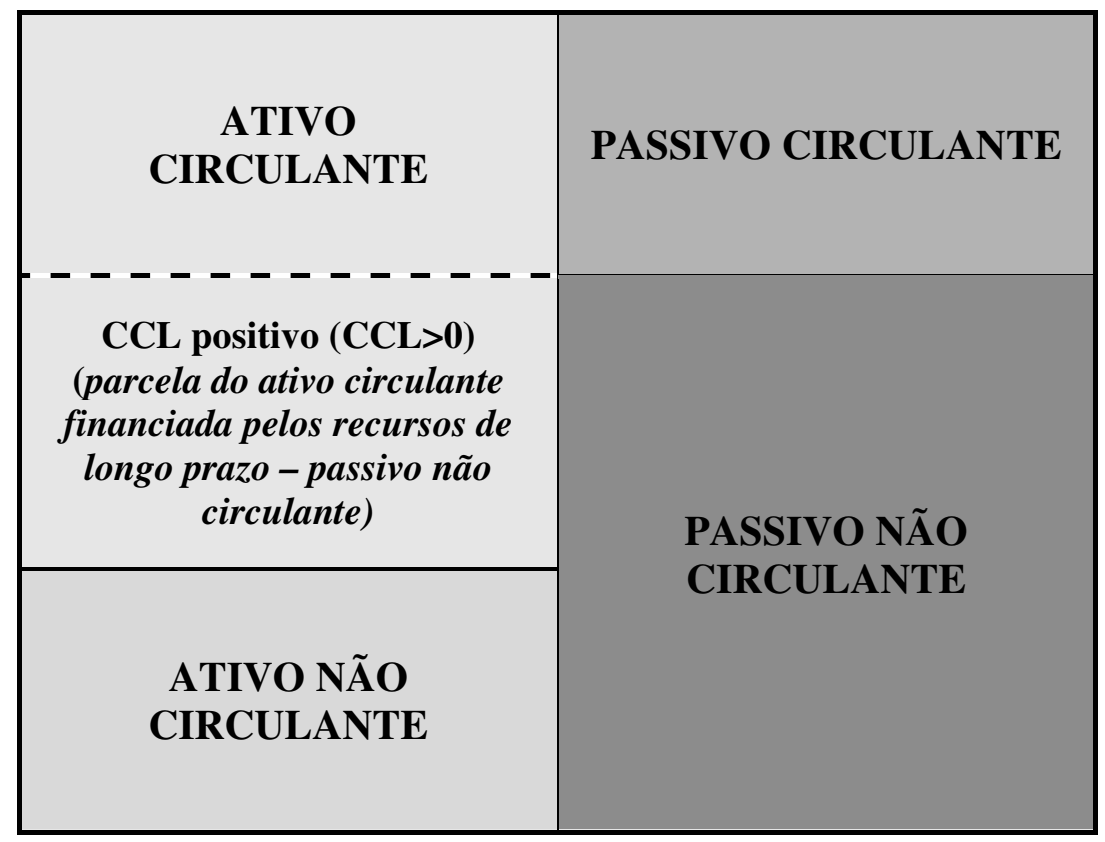

Visualiza-se na figura acima que uma parte do ativo circulante é financiada pelos recursos de longo prazo componentes do passivo não circulante. Isso faz com que a entidade em análise tenha folga de liquidez para cumprir seus compromissos de curto prazo.

A situação pode ser justamente a inversa, ou seja, existir CCL negativo, o que representaríamos na seguinte forma.

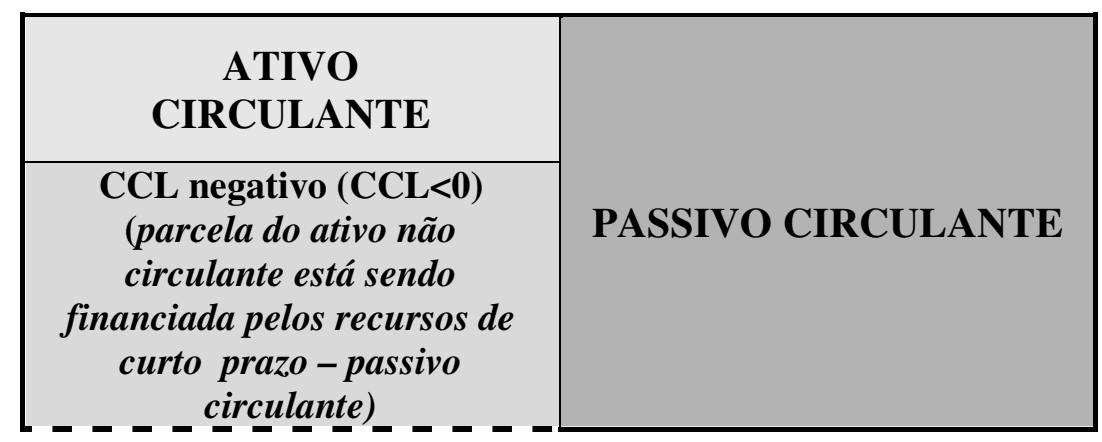




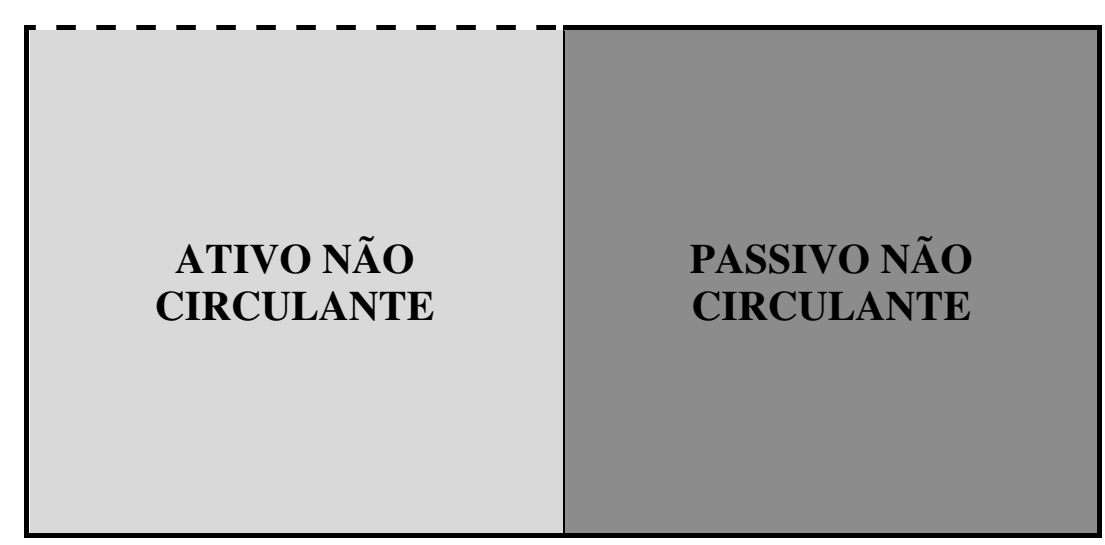

Neste último caso, em razão de o financiamento de ativos de longo prazo (não circulantes) ser feito por recursos de curto prazo (passivo circulante), poderá haver descasamento de prazo de aplicações e origens de recursos.

Além de positivo ou negativo, o CCL pode ser igual a zero ${ }^{138}$.

Deve-se salientar que o capital circulante líquido tem duas facetas bem distintas, podendo causar benefícios e prejuízos ao mesmo tempo. Se por um lado a existência de CCL positivo facilita o cumprimento das obrigações de curto prazo pela existência de recursos líquidos, por outro proporciona uma série de custos em ativos (e.g., os custos de manutenção de estoques).

Na lição de Lawrence J. Gitman ${ }^{138 \mathrm{~A}, ~ “ G e r a l m e n t e, ~ q u a n t o ~ m a i o r ~ o ~ c a p i t a l ~}$ circulante líquido de uma empresa (ativos circulantes menos passivos circulantes), menor será sua lucratividade e menor o risco de ela não poder pagar suas obrigações no vencimento; por outro lado, quanto menor o capital circulante líquido, maior será a lucratividade da empresa, e maior o risco de ela não poder pagar suas obrigações no vencimento".

Diante da importância do conceito de capital circulante líquido, a demonstração de origens e aplicações de recursos foi criada com a finalidade de evidenciar os aumentos (origens) e as diminuições (aplicações) que afetam o CCL.

\footnotetext{
${ }^{138}$ Há autores que defendem a tese do CCL igual a zero, em termos de administração financeira. Entre eles BRIGHAM, Eugene F. et al. Administração financeira: teoria e prática. São Paulo: Atlas, 2001.

138A GITMAN, Lawrence J. Op. cit., 1997. p. 618.
} 
O objetivo da DOAR, portanto, é trazer à luz os motivos pelos quais o capital de giro líquido de uma empresa se alterou de um período para outro.

$\mathrm{Na}$ demonstração supracitada, devem ser evidenciados os tipos de origens (da atividade, dos sócios ou de terceiros) e das aplicações, nos termos do art. 188 da Lei n. 6.404/76, a seguir transcrito.

Art. 188. A demonstração das origens e aplicações de recursos indicará as modificações na posição financeira da companhia, discriminando:

I - as origens dos recursos, agrupadas em:

a) lucro do exercício, acrescido de depreciação, amortização ou exaustão e ajustado pela variação nos resultados de exercícios futuros;

b) realização do capital social e contribuições para reservas de capital;

c) recursos de terceiros, originários do aumento do passivo exigível a longo prazo, da redução do ativo realizável a longo prazo e da alienação de investimentos e direitos do ativo imobilizado.

II - as aplicações de recursos, agrupadas em:

a) dividendos distribuídos;

b) aquisição de direitos do ativo imobilizado;

c) aumento do ativo realizável a longo prazo, dos investimentos e do ativo diferido;

d) redução do passivo exigível a longo prazo. 
III - o excesso ou insuficiência das origens de recursos em relação às aplicações, representando aumento ou redução do capital circulante líquido;

IV - os saldos, no início e no fim do exercício, do ativo e passivo circulantes, o montante do capital circulante líquido e o seu aumento ou redução durante o exercício.

Para a elaboração da DOAR, é necessário ver qual a modificação havida no CCL durante o período que se pretende analisar.

Considerando o balanço patrimonial dos exercícios de 2006 e 2007 apresentado nos exemplos anteriores, tínhamos:

Quadro 28: variação do CCL entre os exercícios de 2006 e 2007

\begin{tabular}{|c|c|c|c|}
\hline & 2006 & 2007 & \multirow{3}{*}{$\begin{array}{c}\text { Variação de } \\
\text { CCL } \\
\text { 2006/2007 }\end{array}$} \\
\hline $\begin{array}{c}\text { Ativo } \\
\text { circulante }\end{array}$ & $717.500,00$ & $619.600,00$ & \\
\hline $\begin{array}{c}\text { Passivo } \\
\text { circulante }\end{array}$ & $(25.400,00)$ & $(81.600,00)$ & \\
\hline CCL & $692.100,00$ & $538.000,00$ & $(154.100,00)$ \\
\hline
\end{tabular}

Para demonstrarmos a variação de CCL descrita acima, temos de partir inicialmente do prejuízo do período, que será considerado nas aplicações de recursos, por diminuir o CCL. O resultado deverá ser ajustado, retirando-se dele aquelas rubricas que não afetaram o CCL, como a depreciação.

Em seguida, poderemos fazer a demonstração verificando quais contas do ativo e passivo não circulantes afetaram o CCL, demonstrando-as na forma seguinte: 
Quadro 29: Demonstração de Origens e Aplicações de Recursos do exercício de 2007

Origens

Das atividades

Dos sócios

Aumento de capital

$100.000,00$

De terceiros

\begin{tabular}{lr}
\hline Total das origens & $\mathbf{1 0 0 . 0 0 0 , 0 0}$ \\
\hline Aplicações & \\
& \\
Prejuízo do período & $(269.100,00)$ \\
(+) Depreciação & $15.000,00$ \\
(=) Resultado ajustado & $(254.100,00)$ \\
\hline Total das aplicações & \\
\hline & $(\mathbf{2 5 4 . 1 0 0 , 0 0 )}$ \\
\hline (=) Variação no capital circulante líquido & $\mathbf{( 1 5 4 . 1 0 0 , 0 0 )}$ \\
\hline
\end{tabular}

Veja-se que o resultado do período (prejuízo), já descontado pelos valores de depreciação, fez com que se diminuísse sensivelmente o capital circulante líquido, por absorver recursos do caixa da entidade, sendo que o aporte de capital, constituindo-se em fonte de financiamento de longo prazo, atenuou a referida diminuição, aumentando o CCL em contrapartida.

As atividades em nada contribuíram para o aumento do CCL, pelo contrário, fizeram com que este diminuísse em face do prejuízo.

Outrossim, o empréstimo tomado de terceiros a curto prazo ( $\mathrm{R} \$ 50.000,00)$ não é aqui considerado, uma vez que se situa no passivo circulante, não se constituindo, portanto, em fonte de financiamento de longo prazo. 


\subsection{Demonstração de Valor Adicionado (DVA)}

Essa demonstração também passou a ser exigida na legislação de sociedades anônimas com o advento Lei n. 11.638/07, ao dar nova redação ao art. 176, V, da Lei n. 6.404/76, exigindo que tal demonstração evidencie o valor da riqueza gerada pela companhia, a sua distribuição entre os elementos que contribuíram para a geração dessa riqueza, tais como empregados, financiadores, acionistas, governo e outros, bem como a parcela da riqueza não distribuída.

As demonstrações anteriormente tratadas até aqui, muito embora se destinem à utilização de usuários internos e externos ao ente representado, têm um cunho essencialmente individualista.

Com efeito, nenhuma das demonstrações antes vistas tem o condão de demonstrar quanto a entidade agregou de valor aos insumos que captou da sociedade em que está inserida, nem mesmo quanto esta devolveu à sociedade dos recursos captados.

Assim, a demonstração do valor adicionado surge como uma forma de a ciência contábil demonstrar a riqueza gerada e distribuída de uma determinada entidade, promovendo uma espécie de "contabilidade social" da empresa.

Várias são as repercussões práticas da DVA no cenário atual, muito embora nossa legislação não a exija de qualquer um dos tipos societários presentes em nossa legislação. A doutrina aponta a demonstração de valor adicionado como instrumento relevante na análise governamental de empresas destinada à concessão de empréstimos ou incentivos fiscais e até mesmo para cálculo do Produto Interno Bruto.

Ariovaldo dos Santos ressalta a importância da demonstração do valor adicionado, em confronto com a demonstração de resultado do exercício: "Como se percebe, na demonstração de resultados o enfoque está dirigido para a linha do lucro líquido e, dessa forma, seu interesse é muito maior para proprietários sócios ou acionistas. Os demais componentes da demonstração de resultados são apresentados de acordo com sua natureza e não segundo seus beneficiários. Por exemplo, na demonstração 
de resultados, as remunerações pagas aos empregados podem ser expostas como componentes do custo elou das despesas operacionais; os diversos impostos e taxas incidentes sobre as vendas, resultado, operações financeiras, etc., podem ser apresentados em linhas totalmente diversas na demonstração de resultados (...) Já para a DVA, a distribuição da riqueza gerada pela empresa obedecerá ao critério do beneficiário da renda. Assim, a distribuição será apresentada entre os detentores de capitais, acionistas e financiadores externos, os trabalhadores, destacando-se os salários e encargos e, finalmente, a parte destinada ao governo na forma de impostos, que podem ser municipais, estaduais ou federais. Quanto à importância da DVA, parece que é inquestionável seu auxílio no cálculo do PIB e de indicadores sociais extremamente importantes. As decisões de investimentos por áreas, regiões, Estados, etc., terão nessa demonstração excelente instrumental para auxiliar na solução de conflitos" ${ }^{\prime 39}$.

Vários são os modelos utilizados para a apresentação da DVA. Aqui adotaremos aquele apresentado por Neves e Viceconti ${ }^{140}$, a seguir transcrito:

\section{I - Geração do Valor Adicionado - Elementos}

Receitas operacionais e não operacionais

(-) Custo das mercadorias, produtos e serviços vendidos

(-) Serviços adquiridos de terceiros

(-) Materiais e insumos, energia, comunicação, propaganda, etc.

(-) Outros valores

(=) Valor Bruto Adicionado

(-) Despesas de Depreciação

(=) Valor Adicionado Líquido

(+) Valores remunerados por terceiros (juros, aluguéis e outros)

(=) Valor adicionado à disposição da empresa

II - Distribuição do Valor Adicionado

Remuneração do trabalho

Remuneração do governo (impostos e contribuições)

Remuneração do capital de terceiros (juros, aluguéis, etc.)

Remuneração do capital próprio (dividendos e lucros retidos)

Outros

(=) Total do valor distribuído (igual ao do valor gerado)

\footnotetext{
${ }^{139}$ SANTOS, Ariovaldo dos. Demonstração do Valor Adicionado: como elaborar e analisar a DVA. São Paulo: Atlas, 2003. p. 36.

${ }^{140}$ NEVES, Silvério das; VICECONTI, Paulo Eduardo Vilchez. Contabilidade avançada e análise das demonstrações financeiras. São Paulo: Frase, 1999. p. 263.
} 
Lançando mão do exemplo utilizado nas demonstrações anteriores, teríamos a seguinte DVA:

Quadro 30: Demonstração de Valor Adicionado do exercício de 2007

\begin{tabular}{l|r}
\hline I-Geração do Valor Adicionado & \\
\hline Receitas operacionais e não operacionais & $120.000,00$ \\
(-) Custo das mercadorias, produtos e serviços vendidos & $(52.500,00)$ \\
(-) Outros valores (despesas operacionais) & $(50.000,00)$ \\
(=) Valor Bruto Adicionado & $\mathbf{1 7 . 5 0 0 , 0 0}$ \\
(-) Despesas de Depreciação & $(15.000,00)$ \\
(=) Valor Adicionado Líquido & $\mathbf{2 . 5 0 0 , 0 0}$ \\
(+) Valores remunerados por terceiros (juros, aluguéis e & - \\
outros) & \\
(=) Valor adicionado à disposição da empresa & $\mathbf{2 . 5 0 0 , 0 0}$ \\
\hline II - Distribuição do Valor Adicionado & \\
\hline Remuneração do trabalho & $250.000,00$ \\
Remuneração do governo (impostos) & $21.600,00$ \\
Remuneração do capital próprio (prejuízo retido) & $(269.100,00)$ \\
\hline (=) Total do valor distribuído & $\mathbf{2 . 5 0 0 , 0 0}$ \\
\hline
\end{tabular}

Pode-se verificar que, muito embora a entidade em análise tenha gerado receitas operacionais de $\mathrm{R} \$ 120.000,00$, sua geração de valor adicionado é de somente $\mathrm{R} \$$ $2.500,00$, demonstrando seu baixo incremento de valor em tal aspecto. Veja-se ainda que tal panorama não irá se alterar mesmo na hipótese de a principal despesa (remuneração do trabalho no valor de $\mathrm{R} \$ 250.000,00)$ vir a sofrer redução, uma vez que esta somente influencia a distribuição do valor adicionado e não sua criação.

\subsection{Correção monetária das demonstrações}

Os lançamentos efetuados na escrituração empresarial levam ordinariamente em consideração os valores históricos, ou mesmo os valores de mercado. 
No entanto, se bem observarmos, a informação gerada pela escrituração não será completa se esta não cuidar de um importante efeito econômico, qual seja, a perda de capacidade aquisitiva da moeda ou inflação.

Com efeito, seria errôneo considerar que determinada quantia lançada na escrituração de uma determinada entidade a título de entrada no caixa mantivesse um mesmo valor, depois de passar por um período de inflação que corroesse parte do poder aquisitivo da quantia escriturada.

Daí por que se torna importantíssimo considerar na escrituração, e principalmente nas demonstrações contábeis que dela se originam, os efeitos da inflação, consistentes na perda de poder aquisitivo da moeda.

\subsubsection{Propositura do problema}

Fixada a relevância de se considerarem as conseqüências da inflação nas demonstrações contábeis, é preciso colocar, neste momento, como se poderá incluir referidos efeitos nos relatórios emitidos.

A questão inicial consiste em fazer uma distinção entre itens monetários e não monetários, cuja definição apresentamos a seguir.

- Itens monetários: são aqueles itens apresentados no balanço patrimonial e na demonstração de resultado do exercício, passíveis de avaliação imediata em dinheiro, representados pelas disponibilidades (caixa, aplicações financeiras, etc.) ou as obrigações exigíveis em moeda (fornecedores, títulos a pagar, etc.);

- Itens não monetários: constituem as demais contas componentes do balanço patrimonial e demonstração de resultado do exercício. 
O que importa considerar aqui é que os ativos e passivos monetários, expostos a inflação, sofrerão imediatamente seus efeitos, em razão das modificações do poder aquisitivo da moeda. Um ativo monetário (e.g., os valores em caixa), quando sob o efeito inflacionário, gerará certamente uma perda, pois será menor sua capacidade de aquisição de outros bens, enquanto um passivo monetário na mesma situação gerará um ganho, uma vez que representará uma obrigação com valor corroído pelos efeitos inflacionários.

Isso não ocorre com os ativos e passivos não monetários que, mesmo expostos a inflação, não sofrem perda ou ganho.

Dessa forma, a correta escrituração dos fatos econômicos empresariais deverá levar em consideração os efeitos inflacionários sobre os itens monetários e não monetários.

Até mesmo para a comparabilidade das demonstrações, entre diversos exercícios, não é correto, conceitualmente, comparar valores em moeda de uma determinada data com outros em moeda que já tenha sofrido os efeitos da inflação. A ausência de correção monetária nas demonstrações poderá levar o usuário das informações contábeis a sérios erros de interpretação e decisão.

Diante dessa constatação, cabe verificar as soluções dadas pela legislação pátria para equacionar o problema.

\subsubsection{Soluções dadas pela legislação brasileira}

A Lei n. 6.404/76 adotava método especial para a aplicação da correção monetária sobre as demonstrações, nos termos do art. 185, a seguir transcrito. 
Art. 185. Nas demonstrações financeiras deverão ser considerados os efeitos da modificação no poder de compra da moeda nacional sobre o valor dos elementos do patrimônio e os resultados do exercício.

$\S l^{o}$ Serão corrigidos, com base nos índices de desvalorização da moeda nacional, reconhecidos pelas autoridades federais:

a) o custo de aquisição dos elementos do ativo permanente, inclusive os recursos aplicados no ativo diferido, os saldos das contas de depreciação, amortização e exaustão, e as provisões para perdas;

b) os saldos das contas do patrimônio líquido.

$\S 2^{\circ}$ A variação nas contas do patrimônio líquido, decorrente de correção monetária, será acrescida aos respectivos saldos, com exceção da correção do capital realizado, que constituirá reserva de capital de que trata o $\S 2^{o}$ do artigo 182.

$\S 3^{\circ}$ As contrapartidas dos ajustes de correção monetária serão registradas em conta cujo saldo será computado no resultado do exercício.

Verifica-se pela leitura do dispositivo supracitado que as contas que deveriam sofrer reajustes eram somente aquelas componentes do balanço patrimonial, relativas ao grupo do ativo permanente e do patrimônio líquido.

Para receber a contrapartida dos acréscimos em cada conta a título de correção monetária, criou-se uma conta específica de resultado (normalmente denominada "resultado da correção monetária" ou "correção monetária do exercício") a ser evidenciada na demonstração de resultado do exercício.

Uma exceção era admitida, quando a correção atingisse a conta de capital realizado, a qual deveria ser contabilizada em reserva de capital contra a rubrica de resultado de correção monetária. Isso se justificava, uma vez que qualquer aumento na conta de capital deveria passar por deliberação dos órgãos próprios e alteração contratual. 
A lógica do art. 185 da Lei n. 6.404/76 era razoavelmente simples, embora sujeita a algumas imperfeições. Como vimos no tópico anterior, os itens sujeitos aos efeitos da inflação (perda de poder aquisitivo da moeda) eram os chamados itens monetários.

Se verificarmos bem, recapitulando a estrutura do balanço patrimonial, os ativos monetários correspondem basicamente às disponibilidades (caixa, aplicações, etc.), às contas a receber (clientes, duplicatas, etc.), entre outras. Os ativos não monetários corresponderiam, grosso modo, ao ativo permanente (imobilizado, investimentos e diferido). O mesmo ocorre com os passivos monetários, representados em regra pelo circulante e exigível a longo prazo e os não monetários pelo patrimônio líquido.

Como os ativos monetários expostos à inflação geram perdas e os passivos monetários na mesma situação geram ganhos, a diferença entre as perdas e os ganhos apurados em tais itens corresponderia ao resultado da correção monetária a ser incluído na demonstração de resultados do exercício.

Graficamente teríamos o seguinte:

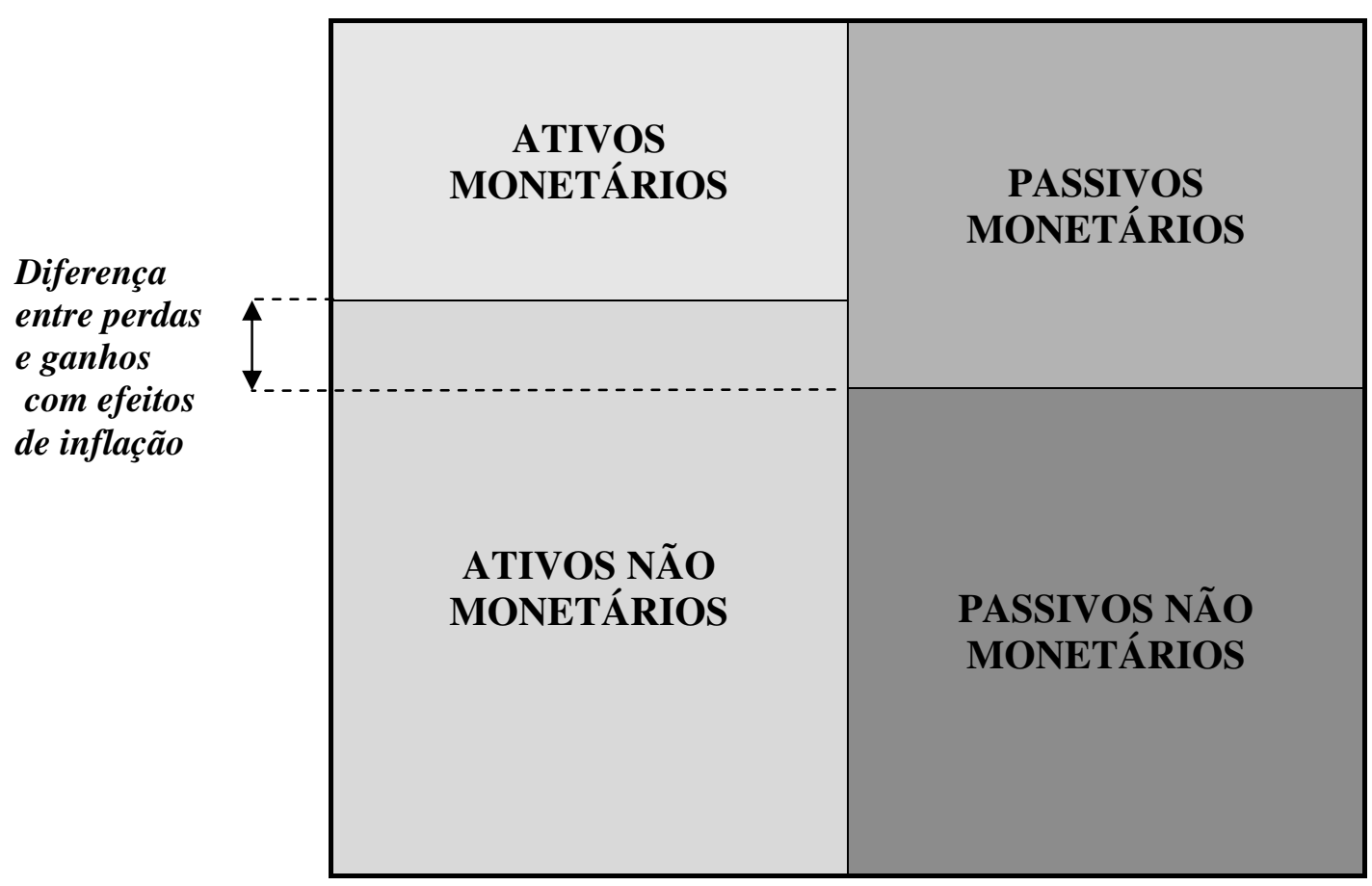


Visualizando a figura anterior, podemos constatar também que a diferença apontada entre as perdas e ganhos nos itens monetários pode ser também apurada através da soma algébrica de perdas e ganhos nos itens não monetários.

Em outras palavras, o resultado da correção monetária pode ser obtido pela diferença entre itens (ativos e passivos) monetários ou não monetários corrigidos.

Essa última forma de avaliação dos efeitos inflacionários sobre a escrituração foi a maneira adotada pelo art. 185 da Lei n. 6.404/76 para a utilização e aplicação da correção monetária sobre as demonstrações contábeis.

Corrigiam-se os passivos não monetários (constantes do patrimônio líquido) e os ativos não monetários (constantes do ativo permanente), lançando-se a contrapartida da correção a débito e a crédito em conta de resultado. A apuração do saldo desta última conta era correspondente à diferença entre as perdas e ganhos nos itens monetários.

O método, entretanto, possui algumas falhas.

Primeiramente, há itens que compõem o ativo circulante ou realizável a longo prazo que não são monetários (e.g., as contas de estoque, imóveis não classificados no ativo permanente, etc.), no entanto, acabavam por assim ser considerados na sistemática legal então adotada.

Como as contas representativas de itens monetários não eram corrigidas, não se sabia com precisão de onde vieram as perdas e ganhos com os efeitos da inflação. Isso reduzia indevidamente o nível de informações das demonstrações corrigidas, causando distorções e penalizando o usuário.

Não havia qualquer sistemática destinada a trazer a valor presente contas do balanço que estivessem expressas em valores futuros (p. ex., as contas de clientes e fornecedores).

Contas de resultado, representativas de receitas e despesas, não sofriam correção individualizada, acrescendo-se meramente uma conta específica (resultado da 
correção monetária) na qual eram lançados todos os efeitos da perda de poder aquisitivo da moeda.

Após algum tempo de utilização, o método de correção monetária instituído pela Lei n. 6.404/76 foi revogado pela Lei n. 7.738/89, diploma que trouxe em seu art. 27 a seguinte redação:

\begin{abstract}
Art. 27. Nas demonstrações contábeis das pessoas jurídicas deverão ser considerados os efeitos da modificação no poder de compra da moeda nacional sobre o valor dos elementos do patrimônio e os resultados do exercício, segundo critérios a serem fixados em decreto.
\end{abstract}

Posteriormente a este último diploma, cujo decreto regulamentador não foi editado, vigoraram as Leis n. $7.799 / 89^{141}$ e n. $8.200 / 91^{142}$, que regulamentaram a utilização

\footnotetext{
${ }^{141}$ Art. $4^{\circ}$ Os efeitos da modificação do poder de compra da moeda nacional sobre o valor dos elementos do patrimônio e os resultados do período-base serão computados na determinação do lucro real mediante os seguintes procedimentos: I - correção monetária, na ocasião da elaboração do balanço patrimonial: a) das contas do ativo permanente e respectiva depreciação, amortização ou exaustão, e das provisões para atender a perdas prováveis na realização do valor de investimentos; b) das contas representativas do custo dos imóveis não classificados no ativo permanente; c) das contas representativas das aplicações em ouro; d) das contas representativas de adiantamentos a fornecedores de bens sujeitos à correção monetária, salvo se o contrato previr a indexação do crédito; e) das contas integrantes do patrimônio líquido; f) de outras contas que venham a ser determinadas pelo Poder Executivo, considerada a natureza dos bens ou valores que representem; II - registro, em conta especial, das contrapartidas dos ajustes de correção monetária de que trata o item I; III - dedução, como encargo do período-base, do saldo da conta de que trata o item II, se devedor; IV - observado o disposto na Seção III deste Capítulo, cômputo no lucro real do saldo da conta de que trata o item II, se credor.

${ }^{142}$ Art. $2^{\circ}$ As pessoas jurídicas tributadas com base no lucro real poderão efetuar correção monetária especial das contas do Ativo Permanente, com base em índice que reflita a nível nacional, variação geral de preços. $\S 1^{\circ}$ A correção monetária de que trata este artigo poderá ser efetuada, exclusivamente, em balanço especial levantado, para esse efeito, em 31 de janeiro de 1991, após a correção com base no BTN Fiscal de Cr\$ 126,8621. $\$ 2^{\circ}$ A correção deverá ser registrada em subconta distinta da que registra o valor original do bem ou direito, corrigido monetariamente, e a contrapartida será creditada à conta de reserva especial. $\$ 3^{\circ}$ O valor da reserva especial, mesmo que incorporado ao capital, deverá ser computado na determinação do lucro real proporcionalmente à realização dos bens ou direitos, mediante alienação, depreciação, amortização, exaustão ou baixa a qualquer título. $\$ 4^{\circ} \mathrm{O}$ valor da correção especial, realizado mediante alienação, depreciação, amortização, exaustão ou baixa a qualquer título, poderá ser deduzido como custo ou despesa, para efeito de determinação do lucro real. $\$ 5^{\circ} \mathrm{O}$ disposto nos $\$ \S 3^{\circ}$ e $4^{o}$, deste artigo aplica-se, inclusive, à determinação da base de cálculo da contribuição social (Lei $n$. 7.689, de 15 de dezembro de 1988), e do imposto de renda na fonte incidente sobre o lucro líquido (Lei n. 7.713, de 22 de dezembro de 1988, art. 35). § $6^{\circ}$ A correção de que trata este artigo poderá ser registrada até a data do balanço de encerramento do período-base de 1991, mas referida à data de 31 de janeiro de 1991 . $\S 7^{\circ}$ A correção especial não se aplica em relação a investimentos avaliados pelo valor de patrimônio líquido. $\S 8^{\circ} A$ contrapartida do ajuste do investimento avaliado pelo valor do patrimônio líquido, decorrente da correção especial efetuada por coligada ou controlada, deverá ser registrada, pela investidora, em conta de reserva especial, que terá o mesmo tratamento tributário aplicável à reserva de reavaliação.
} 
da correção monetária para fins fiscais. A sistemática da Lei n. 6.404/76, entretanto, foi mantida em linhas gerais, com algumas melhorias derivadas da inclusão de algumas contas a serem atingidas pela correção, como aquelas referentes a imóveis não classificadas no ativo permanente.

A pequena evolução foi percebida por Modesto Carvalhosa, o qual ressalta, em comentário ao Decreto n. 322/91 (que regulamentou as Leis n. 7.799/89 e n. 8.200/91): "Nota-se, com isso, uma evolução em face da Lei $n$. 6.404/76, pois adiciona a obrigatoriedade de correção de outras contas que não as do ativo permanente e do patrimônio líquido. Todavia, contas importantes, que, se não corrigidas, chegam a distorcer completamente o resultado do período, ainda estão fora da obrigação legal e fiscal da correção, destacando-se os estoques, os adiantamentos e fornecedores de estoques e os adiantamentos de clientes. A ausência de correção dessas contas e mais os ajustes a valor presente das contas monetárias prefixadas que embutiam taxa prevista de inflação (clientes e fornecedores, principalmente) propiciavam balanços e resultados distorcidos. E por não serem corrigidas as despesas e receitas, os componentes do resultado continuaram também sem capacidade informativa, pelo menos enquanto a inflação esteve alta"143.

Buscando um modelo mais adequado e mais consentâneo com as necessidades de informação dos usuários das demonstrações contábeis, a Comissão de Valores Mobiliários editou a Instrução CVM n. 191, de 15 de julho de 1992. Referida norma, entre outras disposições, trouxe as seguintes inovações em matéria de aplicação da correção monetária nas demonstrações financeiras:

1. Instituiu o sistema de correção monetária integral, no qual todas as contas componentes do balanço patrimonial e da demonstração de resultado do exercício devem ser corrigidas segundo critérios próprios para cada qual. Os efeitos da aplicação da correção monetária devem ser expressos em cada conta corrigida. Exigiu ainda a aplicação de correção monetária na demonstração de mutações no patrimônio líquido (DMPL) e na demonstração de origens e aplicações de recursos (DOAR);

${ }^{143}$ CARVALHOSA, Modesto; LATORRACA, Nilton. Op. cit., 1998. v. 3, p. 648. 
2. Criou a chamada Unidade Monetária Contábil (UMC), equiparando-a, então, à Unidade Fiscal de Referência Diária (UFIR - Diária);

3. Determinou que as contas expressas em valores futuros deveriam ser ajustadas a valor presente, com base na taxa média nominal de juros divulgada diariamente pela Associação Nacional dos Bancos de Investimento - ANBID;

4. Definiu e determinou a forma de apresentação e aplicação de correção monetária aos itens monetários e não monetários.

Muito embora a disciplina da correção monetária adotada pela Instrução 191/92 da CVM tenha o beneplácito da doutrina ${ }^{144}$, sua obrigatoriedade foi suprimida com o advento da Lei n. 9.249/95, que em seu art. $4^{\circ}$ dispôs que:

Art. $4^{o}$ Fica revogada a correção monetária das demonstrações financeiras de que tratam a Lei $n$. 7.799, de 10 de julho de 1989, e o art. $1^{\circ}$ da Lei $n$. 8.200, de 28 de junho de 1991.

Parágrafo único. Fica vedada a utilização de qualquer sistema de correção monetária de demonstrações financeiras, inclusive para fins societários.

Diante da nova ordem legal, a CVM baixou a Instrução CVM n. 248, de 29 de março de 1996, determinando o seguinte:

Art. $1^{o}$ - As demonstrações financeiras e as informações trimestrais exigidas nos atos normativos da CVM, em especial nas Instruções CVM $n$. 202, de 06 de dezembro de 1993, n. 206, de 14 de janeiro de 1994, n. 207, de 01 de fevereiro de 1994 e n. 232, de 10 de fevereiro de 1995, devem ser elaboradas e divulgadas na forma da legislação societária, modificada

\footnotetext{
${ }^{144}$ Fundação Instituto de Pesquisas Contábeis, Atuariais e Financeiras. Aprendendo contabilidade em moeda constante. São Paulo: Atlas, 2004.
} 
pelos artigos $4^{o}$ e $5^{\circ}$ da Lei $n$. 9.249/95, passando a ser facultativa a sua elaboração e divulgação em moeda de capacidade aquisitiva constante.

Art. $2^{o}$ - As companhias abertas que divulgarem, no exterior, demonstrações ou informações adicionais às requeridas pela legislação societária e pelas normas desta Comissão deverão, simultaneamente, divulgá-las também no País.

Art. $3^{o}$ - Esta Instrução entra em vigor na data de sua publicação, aplicando-se às informações trimestrais - ITR e demonstrações financeiras relativas aos períodos e exercício social a se encerrarem a partir de março de 1996.

Art. $4^{o}$ - Ficam revogados o artigo $1^{o}$ da Instrução CVM $n .191$, de 15 de julho de 1992, e a Instrução CVM n. 201, de $1^{o}$ de dezembro de 1993, adaptando-se à presente Instrução as demais normas da Comissão de Valores Mobiliários que tratam dessa matéria.

A crítica à Lei n. 9.249/95, formulada por alguns autores, é, a nosso ver, integralmente procedente.

Muito embora os tempos de inflação galopante já façam parte do passado, é fato que o fenômeno relativo à perda do poder aquisitivo da moeda ainda existe e pode ser relevante a ponto de distorcer a informação contábil. Pedimos vênia para repetir aqui a crítica de Iudícibus et al., que ensinam: "O enfoque essencialmente fiscal que as autoridades governamentais têm inserido em seus estudos não só ignora essa tendência mundial como também representa um retrocesso em relação a algumas evoluções já conquistadas. Situam-se nesse campo, por exemplo, a proibição, inclusive para fins societários, do reconhecimento dos efeitos da inflação nas demonstrações contábeis e de redução ou até mesmo de eliminação de provisões tecnicamente corretas e necessárias. 
Essa é uma atitude que, para nós, parece muito pouco madura e incompatível com o objetivo de modernização do Brasil, como todos procuramos ${ }^{\prime 145}$.

\subsection{Demonstrações consolidadas}

Muitas vezes, entretanto, não basta a análise isolada das demonstrações contábeis de uma determinada entidade.

Com efeito, quando existe a formação de grupos econômicos ou determinados graus de participação de uma entidade em outra ${ }^{146}$, é mister, segundo a legislação societária, que sejam apresentadas as demonstrações de forma consolidada.

A Lei n. 6.404/76 disciplina a consolidação das demonstrações contábeis na seguinte forma:

Art. 249. A companhia aberta que tiver mais de $30 \%$ (trinta por cento) do valor do seu patrimônio líquido representado por investimentos em sociedades controladas deverá elaborar e divulgar, juntamente com suas demonstrações financeiras, ${ }^{147}$ demonstrações consolidadas nos termos do artigo 250.

\footnotetext{
${ }^{145}$ IUDÍCIBUS, Sérgio de; MARTINS, Eliseu; GELBCKE, Ernesto Rubens. Op. cit., 2003. p. 29.

${ }^{146}$ Importante ressaltar que a Lei n. 6.404/76 veda as participações recíprocas entre sociedades (controladora e controladas e/ou coligadas) no caput do art. 244, fulminando a doutrina pena de nulidade para o descumprimento (nesse sentido NETO, Alfredo Sérgio Lazzareschi. Lei das sociedades por ações anotada. São Paulo: Atlas, 2006, p.478).

${ }^{147}$ Veja-se que, nos termos dos arts. 249 e 275 da Lei n. 6.404/76, a consolidação não dispensa a divulgação das demonstrações individuais da controladora, nem de suas matrizes, filiais, controladas ou coligadas. Talvez isso se baseie no fato de que, muito embora a consolidação forneça uma informação útil sobre o todo formado pelo agrupamento empresarial, não pode negar ao usuário das demonstrações a análise de cada uma das partes que formam os relatórios consolidados. Há doutrinadores, inclusive, que, baseados em pesquisa, chegam a afirmar que a informação desagregada (não consolidada) permite, em alguns casos, melhor avaliação das sociedades analisadas (RASHAD, A.; KHALIK, Abdel. Dicionário enciclopédico de contabilidade. São Paulo: Atlas, 2004).
} 
Parágrafo único. A Comissão de Valores Mobiliários poderá expedir normas sobre as sociedades cujas demonstrações devam ser abrangidas na consolidação, $e$ :

a) determinar a inclusão de sociedades que, embora não controladas, sejam financeira ou administrativamente dependentes da companhia;

b) autorizar, em casos especiais, a exclusão de uma ou mais sociedades controladas.

Normas sobre Consolidação

Art. 250. Das demonstrações financeiras consolidadas serão excluídas:

I - as participações de uma sociedade em outra;

II - os saldos de quaisquer contas entre as sociedades;

III - as parcelas dos resultados do exercício, dos lucros ou prejuízos acumulados e do custo de estoques ou do ativo permanente que corresponderem a resultados, ainda não realizados, de negócios entre as sociedades.

$\S 1^{\circ}$ A participação dos acionistas não controladores no patrimônio líquido e no lucro do exercício será destacada, respectivamente, no balanço patrimonial e na demonstração do resultado do exercício. (redação dada pela Lei 9.457 de 05.5.97)

$\S 2^{o}$ A parcela do custo de aquisição do investimento em controlada, que não for absorvida na consolidação, deverá ser mantida no ativo permanente, com dedução da provisão adequada para perdas já comprovadas, e será objeto de nota explicativa. 
$\S 3^{\circ} \mathrm{O}$ valor da participação que exceder do custo de aquisição constituirá parcela destacada dos resultados de exercícios futuros até que fique comprovada a existência de ganho efetivo.

$\S 4^{\circ}$ Para fins deste artigo, as sociedades controladas, cujo exercício social termine mais de 60 (sessenta) dias antes da data do encerramento do exercício da companhia, elaborarão, com observância das normas desta Lei, demonstrações financeiras extraordinárias em data compreendida nesse prazo.

Art. 275. O grupo de sociedades publicará, além das demonstrações financeiras referentes a cada uma das companhias que o compõem, demonstrações consolidadas, compreendendo todas as sociedades do grupo, elaboradas com observância do disposto no artigo 250.

$\S 1^{\circ}$ As demonstrações consolidadas do grupo serão publicadas juntamente com as da sociedade de comando.

$\S 2^{\circ}$ A sociedade de comando deverá publicar demonstrações financeiras nos termos desta Lei, ainda que não tenha a forma de companhia.

$\S 3^{\circ}$ As companhias filiadas indicarão, em nota às suas demonstrações financeiras publicadas, o órgão que publicou a última demonstração consolidada do grupo a que pertencer.

$\S 4^{\circ}$ As demonstrações consolidadas de grupo de sociedades que inclua companhia aberta serão obrigatoriamente auditadas por auditores independentes registrados na Comissão de Valores Mobiliários, $e$ observarão as normas expedidas por essa comissão.

A Comissão de Valores Mobiliários, por seu turno, disciplinou o assunto na Instrução n. 247/96, cujos arts. 21 e 22 preceituam: 
Art. 21 - Ao fim de cada exercício social, demonstrações contábeis consolidadas devem ser elaboradas por:

I. companhia aberta que possuir investimento em sociedades controladas, incluindo as sociedades controladas em conjunto referidas no artigo 32 desta Instrução; $e$

II. sociedade de comando de grupo de sociedades que inclua companhia aberta.

Art. 22 - Demonstrações contábeis consolidadas compreendem o balanço patrimonial consolidado, a demonstração consolidada do resultado do exercício e a demonstração consolidada das origens e aplicações de recursos, complementadas por notas explicativas e outros quadros analíticos necessários para esclarecimento da situação patrimonial e dos resultados consolidados.

A obrigatoriedade de se consolidar as demonstrações contábeis decorre da necessidade de informar ao usuário de referidas demonstrações os efeitos econômicos totais de um grupo ou coligação empresarial, para que se compreendam seus efeitos integrados, tanto internamente quanto em relação a terceiros.

Por outras palavras, a consolidação melhora a qualidade da informação contábil, fornecendo não apenas as características de cada uma das sociedades componentes de um agrupamento, mas dos efeitos globais de sua junção.

Em última análise, a consolidação corresponde à soma dos valores constantes das demonstrações da entidade controladora e da controlada, ou daquelas que pertencem a um grupo comercial.

Há, entretanto, algumas exceções à regra mencionada que incluem alguns itens mencionados na Lei n. 6.404/76 (como os ativos representativos de participações de 
uma sociedade em outra, as transações efetuadas entre as companhias, as questões referentes a lucros não realizados e as participações de minoritários). Para esses casos, deverão ser excluídos mutuamente os valores constantes das contas mencionadas nas demonstrações das entidades envolvidas.

Vejamos um exemplo de autoria do Prof. Ariovaldo Santos, envolvendo duas sociedades anônimas (A - controladora e B - controlada), cujos balanços patrimoniais e demonstrativos de resultado do exercício seriam os seguintes:

Quadro 31: balanço patrimonial da controladora A e da controlada B

\begin{tabular}{|c|c|c|c|c|c|}
\hline & $\mathbf{A}$ & B & & $\mathbf{A}$ & B \\
\hline Ativo & & & Passivo & & \\
\hline Ativo Circulante & & & Passivo Circulante & & \\
\hline Caixa & 508,00 & $1.500,00$ & & & \\
\hline Estoques & $1.500,00$ & $1.000,00$ & Contas a pagar & $2.600,00$ & $1.200,00$ \\
\hline Investimento B & $2.492,00$ & & & & \\
\hline Total do ativo circulante & $4.500,00$ & $2.500,00$ & $\begin{array}{l}\text { Total do passivo } \\
\text { circulante }\end{array}$ & $2.600,00$ & $1.200,00$ \\
\hline Ativo Permanente & & & Patrimônio líquido & & \\
\hline Imobilizado & $3.000,00$ & $2.500,00$ & $\begin{array}{l}\text { Capital + Lucros + } \\
\text { Reservas }\end{array}$ & $4.900,00$ & $3.800,00$ \\
\hline $\begin{array}{l}\text { Total do ativo } \\
\text { permanente }\end{array}$ & $3.000,00$ & $2.500,00$ & $\begin{array}{l}\text { Total do patrimônio } \\
\text { líquido }\end{array}$ & $4.900,00$ & $3.800,00$ \\
\hline Total do ativo & $7.500,00$ & $5.000,00$ & $\begin{array}{l}\text { Total do passivo e } \\
\text { patrimônio líquido }\end{array}$ & $7.500,00$ & $5.000,00$ \\
\hline
\end{tabular}

Quadro 32: demonstrativo do resultado do exercício da controladora A e da controlada B

\begin{tabular}{|lrr|}
\hline Demonstração do resultado do exercício & \multicolumn{1}{c|}{ A } & \multicolumn{1}{c|}{ B } \\
Receita de vendas & $5.000,00$ & $8.000,00$ \\
Custo da mercadoria vendida & $(4.000,00)$ & $(5.500,00)$ \\
Lucro Bruto & $1.000,00$ & $2.500,00$ \\
Despesas & $(500,00)$ & $(500,00)$ \\
Resultado da Equivalência Patrimonial & $1.232,00$ & - \\
Lucro Líquido & $1.732,00$ & $2.000,00$ \\
\hline
\end{tabular}

Supondo os seguintes fatos:

- A controladora A detém 70\% do patrimônio líquido da controlada B; 
- A controlada B vendeu R $\$ 3.000,00$, com $30 \%$ de lucro sobre o preço de compra, para a controladora A, sendo que esta mantém $\mathrm{R} \$ 800,00$ da mercadoria comprada em seu estoque;

Ao realizarmos a consolidação dos demonstrativos, teríamos a seguinte situação:

Quadro 33: balanço patrimonial da controladora A e da controlada B, ajustes e consolidação

\begin{tabular}{|c|c|c|c|c|c|}
\hline \multirow{2}{*}{ Balanço patrimonial } & \multirow{2}{*}{$\mathbf{A}$} & \multirow{2}{*}{ B } & \multicolumn{2}{|c|}{ Ajustes } & \multirow{2}{*}{ Consolidado } \\
\hline & & & Débito & Crédito & \\
\hline \multicolumn{6}{|l|}{ Ativo } \\
\hline \multicolumn{6}{|l|}{ Ativo Circulante } \\
\hline Caixa & 508,00 & $1.500,00$ & & & $2.008,00$ \\
\hline Estoques & $1.500,00$ & $1.000,00$ & & 240,00 & $2.260,00$ \\
\hline Investimento B & $2.492,00$ & - & & $2.492,00$ & - \\
\hline Total do ativo circulante & $4.500,00$ & $2.500,00$ & & & $4.268,00$ \\
\hline \multicolumn{6}{|l|}{ Ativo Permanente } \\
\hline Imobilizado & $3.000,00$ & $2.500,00$ & & & $5.500,00$ \\
\hline Total do ativo permanente & $3.000,00$ & $2.500,00$ & & & $5.500,00$ \\
\hline Total do ativo & $7.500,00$ & $5.000,00$ & & & $9.768,00$ \\
\hline \multicolumn{6}{|l|}{ Passivo } \\
\hline \multicolumn{6}{|l|}{ Passivo Circulante } \\
\hline Contas a pagar & $2.600,00$ & $1.200,00$ & & & $3.800,00$ \\
\hline Acionistas minoritários & - & - & & $1.140,00$ & $1.140,00$ \\
\hline Total do passivo circulante & $2.600,00$ & $1.200,00$ & & & $4.940,00$ \\
\hline Patrimônio líquido & & & & & - \\
\hline Capital + Lucros + Reservas & $4.900,00$ & $3.800,00$ & $\begin{array}{r}240,00 \\
2.492,00 \\
1.140,00\end{array}$ & & $4.828,00$ \\
\hline Total do patrimônio líquido & $4.900,00$ & $3.800,00$ & & & $4.828,00$ \\
\hline $\begin{array}{l}\text { Total do passivo e patrimônio } \\
\text { líquido }\end{array}$ & $7.500,00$ & $5.000,00$ & & & $9.768,00$ \\
\hline
\end{tabular}

Quadro 34: demonstrativo do resultado do exercício da controladora A e da controlada B

\begin{tabular}{|c|c|c|c|c|c|}
\hline \multirow{2}{*}{$\begin{array}{l}\text { Demonstração do resultado do } \\
\text { exercício }\end{array}$} & \multirow{2}{*}{$\mathbf{A}$} & \multirow{2}{*}{ B } & \multicolumn{2}{|c|}{ Ajustes } & \multirow{2}{*}{ Consolidado } \\
\hline & & & Débito & Crédito & \\
\hline Receita de vendas & $5.000,00$ & $8.000,00$ & $3.000,00$ & & $10.000,00$ \\
\hline
\end{tabular}




\begin{tabular}{lrrrr} 
Custo da mercadoria vendida & $(4.000,00)$ & $(5.500,00)$ & $2.760,00$ & $(6.740,00)$ \\
Lucro Bruto & $1.000,00$ & $2.500,00$ & $3.260,00$ \\
Despesas & $(500,00)$ & $(500,00)$ & $(1.000,00)$ \\
Resultado da Equivalência & $1.232,00$ & $-1.232,00$ & - \\
Patrimonial & $1.732,00$ & $2.000,00$ & $2.260,00$ \\
Lucro Líquido & & & $(600,00)$ \\
Lucro de acionistas minoritários & & & $\mathbf{1 . 6 6 0 , 0 0}$ \\
\hline Lucro Consolidado & & &
\end{tabular}

Como se verifica, a consolidação tem por efeito o tratamento das entidades controladora e controlada como um único todo. Assim, os negócios entabulados entre os pertencentes ao agrupamento não são considerados no balanço.

Dessa forma, devem ser excluídos da soma resultante da consolidação o valor do investimento da controladora sobre a controlada, os lucros obtidos nas vendas feitas entre ambas, a participação de minoritários, etc.

No exemplo supracitado, havia no estoque da controladora A $30 \%$ dos lucros da venda efetuada pela controlada B. Como A mantinha $\mathrm{R} \$ 800,00$ das compras em estoque, foram excluídos os $30 \%$ de lucro de B dos estoques da controladora A (R\$ 240,00), lançando-se a contrapartida nos lucros constantes do patrimônio líquido.

Da mesma forma, foram excluídas as participações de B no ativo de A (R\$ $2.492,00)$ e o valor da participação dos acionistas minoritários no patrimônio líquido de B (30\% de $\mathrm{R} \$ 3.800,00=\mathrm{R} \$ 1.140,00)$, também com contrapartida no patrimônio líquido.

A receita de vendas de B para A $(\mathrm{R} \$ 3.000,00)$ também foi excluída, pois realizada apenas entre as duas entidades e não entre terceiros.

Por sua vez, no custo da mercadoria vendida por A a terceiros existe uma parcela do lucro da controlada B na venda para a controladora. Sabemos que A mantém R\$ 800,00 das mercadorias compradas em estoque, tendo vendido R $\$ 2.200,00$. Considerando que B vendeu com $30 \%$ de lucro, a parcela a deduzir do custo das mercadorias vendidas é de $\mathrm{R} \$ 660,00$. Somando-se este último valor ao custo de compra da mercadoria para $\mathrm{B}(\mathrm{R} \$$ $3.000,00-30 \%$ de $\mathrm{R} \$ 3.000,00=2.100,00)$, temos o valor de $\mathrm{R} \$ 2.760,00$. 


\section{REPERCUSSÕES DA ESCRITURAÇÃO, DE SUA AUSÊNCIA OU DEFICIÊNCIA SOB O PONTO DE VISTA JURÍDICO}

A doutrina comercialista costuma apontar algumas repercussões da escrituração regularmente realizada, apontando principalmente para o efeito probatório positivo (prova em favor do empresário) em relação ao conteúdo do processo escritural.

Por outro lado, ressaltam-se normalmente as conseqüências da ausência de escrituração. A doutrina costuma ressaltar que as sanções para a ausência de escrituração são meramente indiretas ou circunstanciais, não havendo, salvo nos casos de crimes falimentares, uma pena específica para o empresário coletivo ou individual que simplesmente não escritura ou escritura irregularmente.

Nesse sentido, é importantíssima a lição de J. X. Carvalho de Mendonça: "Fora dos casos de falência, a lei não cominou penas criminais, mas negou, aos comerciantes pouco cautelosos, certos favores, o que importa dizer que lhes impôs sanções indiretas ou na linguagem dos escritores franceses, sanções civis ou judiciárias. A infração da disposição legal quanto à exigência de livros: 1) priva o comerciante de importante meio de prova, fácil e econômico, nas questões que possa ter; 2) dá ao adversário grande vantagem, nas questões judiciais. Se o comerciante recusa exibir judicialmente os livros para o exame pericial, defere-se juramento à parte contrária e os livros desta, devidamente legalizados, fazem prova contra aquele. Não ter livros para exibir, quando ordenado judicialmente, é o mesmo que recusar a exibição. A lei supõe que o comerciante cumpriu seu preceito; 3) não permite ao comerciante apurar a liquidez e certeza das contas de seus devedores para fundamentar o pedido de falência; 4) obsta a faculdade de requerer a concordata preventiva. A lei não define expressamente esse caso, mas a base fundamental do instituto da concordata preventiva é a boa-fé, a lisura, a probidade do comerciante. A existência de qualquer circunstância ou fato que qualifique a falência 
como culposa ou fraudulenta ou que a esta seja equiparado basta para privar o devedor do benefício legal”, ${ }^{\prime 148}$.

Veja-se, entretanto, que a ausência ou irregularidade de escrituração não ensejará a irregularidade da própria sociedade empresária (v.g. como sociedade irregular ou de fato), ou seja, não terá influência na sua personificação e nas consequiências daí advindas.

Se analisarmos com maior profundidade a questão dos efeitos ou repercussões da escrituração, sua ausência ou deficiência, veremos que há ainda diversas conseqüências ordinariamente não exploradas pela doutrina comercial.

De fato, a escrituração pode ter repercussões não só no Direito Comercial, mas também no Direito Civil, Penal, Administrativo, Tributário e Processual Civil.

Passaremos a seguir à análise das principais repercussões aludidas.

\subsection{Efeitos civis: responsabilidade civil da sociedade e do profissional elaborador pela escrituração}

A escrituração poderá ter sérios efeitos na órbita civil, dentre os quais ressaltamos aqui a possibilidade de responsabilização do empresário coletivo ou individual e do profissional de contabilidade encarregado da elaboração do processo escritural.

No Código Civil de 1916 não havia previsão expressa da responsabilização do empresário e do contador ou técnico que elaborasse a escrituração empresarial.

${ }^{148}$ MENDONÇA, José Xavier Carvalho de. Op. cit., 1906. p. 66. 
Já o novo Código Civil (Lei n. 10.406/02) previu expressamente a hipótese em seu art. 1.177, a seguir transcrito, que regulou a responsabilidade do contabilista como preposto:

Art. 1.177. Os assentos lançados nos livros ou fichas do preponente, por qualquer dos prepostos encarregados de sua escrituração, produzem, salvo se houver procedido de má-fé, os mesmos efeitos como se o fossem por aquele.

Parágrafo único. No exercício de suas funções, os prepostos são pessoalmente responsáveis, perante os preponentes, pelos atos culposos; e, perante terceiros, solidariamente com o preponente, pelos atos dolosos.

O caput do art. 1.177 confere ao preposto regularmente contratado para cuidar da escrituração fiscal um verdadeiro mandato tácito, desde que tenha este obrado de boa-fé. Agindo dessa forma, a escrituração lançada pelo preposto acarretará a responsabilização conjunta, para todos os efeitos, do preponente, sem que este possa alegar que o ato praticado não fora de sua autoria.

Não obstante, caso atuem os contabilistas ou técnicos com negligência, imprudência ou imperícia, responderão por sua culpa perante o preponente (art. 1.177, parágrafo único).

Decisão interessante nesse sentido foi tomada pelo Tribunal de Justiça do Distrito Federal ao responsabilizar o prestador de serviço contábil que, mediante negligência, deu causa à imposição de multa e desclassificação de regime de microempresa pela fiscalização tributária.

Transcrevemos a ementa a seguir: 


\section{Tribunal de Justiça do Distrito Federal}

PROCESSO: APELAÇÃO CÍVEL 19990110013389APC DF ACÓRDÃO: 126164

ÓRGÃO JULGADOR: 1a Turma Cível DATA: 21/02/2000

RELATOR: JOÃO MARIOSA

PUBLICAÇÃO: Diário da Justiça do DF: 31/05/2000 Pág: 12

REFERÊNCIAS LEGISLATIVAS: CÓDIGO CIVIL ART-1056.

CÓDIGO DE PROCESSO CIVIL ART-20 ART-21.

RAMO DO DIREITO: DIREITO CIVIL.

E M E N T A

CIVIL - CONTRATO DE PRESTAÇÃO DE SERVIÇO CONTÁBIL DESCLASSIFICAÇÃO DA EMPRESA COMO MICRO EMPRESA: ERRO DA ADMINISTRAÇÃO FAZENDÁRIA: RESPONSABILIDADE DO PROFISSIONAL ESPECIALIZADO - NEGLIGÊNCIA E OMISSÃO PROFISSIONAL - PREJUÍZO PROVOCADO À EMPRESA COM MULTA FISCAL: REPARABILIDADE. RECURSO PROVIDO

1 - O CONTRATO DE PRESTAÇÃO DE SERVIÇO ESPECIALIZADO, MEDIANTE REMUNERAÇÃO, É ATIVIDADE LABORATIVA DE RESULTADO OBRIGATÓRIO, CONFORME A LEGISLAÇÃO E CÓDIGO DE ÉTICA DA CATEGORIA.

2- SE A ATIVIDADE E RÓTULO DA EMPRESA TÊM POSSIBILIDADE DE REDUZIR OU TORNAR IMUNE ALGUM TIPO DE IMPOSTO, A OMISSÃO E A NEGLIGÊNCIA DO PROFISSIONAL NÃO EVIDENCIAM ERRO DA ADMINISTRAÇÃO FAZENDÁRIA, MAS INÉRCIA CULPOSA DO RESPONSÁVEL PELA ESCRITA CONTÁBIL.

2.1 - AGE COM CULPA O PROFISSIONAL CONTRATADO QUE NÃO PROVIDENCIA OS DOCUMENTOS NECESSÁRIOS PARA 
MANUTENÇÃO DA EMPRESA EM ALGUM PRIVILÉGIO NO SISTEMA FISCAL.

3 - A RESPONSABILIDADE PELO DANO PROVOCADO PELA MUDANÇA DE REGIME FISCAL E AS MULTAS APLICADAS POR NEGLIGÊNCIA NA CONTABILIDADE DEVEM SER TODAS SUPORTADAS POR QUEM SE COMPROMETEU A FAZER O SERVIÇO.

3.1 - OS PREJUÍZOS DECORRENTES DA MÁ CONDUÇÃO DOS SERVIÇOS CONTÁBEIS, PELO CONTADOR, SÃO CULPA EXCLUSIVA SUA, PORQUE NESTE TIPO ESPECIALIZADO DE TRABALHO, QUEM CONTRATA, NÃO ESTIPULA CONDIÇÕES, MAS SUJEITA-SE AOS MÉTODOS E PROCESSOS DA ESPECIALIDADE E DA TÉCNICA.

3.2 - DEFESO FALAR-SE EM CULPA CONCORRENTE ENTRE O CONTRATANTE DO SERVIÇO E O SERVIÇO TÉCNICO CONTÁBIL, QUE SEMPRE É EXERCIDO COM CARÁTER PROFISSIONAL E COM LIBERDADE.

DECISÃO: CONHECER E PROVER, NOS TERMOS DO VOTO DO RELATOR, MAIORIA, VENCIDO O REVISOR.

Perante terceiros, porém, a responsabilidade do profissional de contabilidade ocorrerá somente mediante a prática de atos dolosos ou intencionais, quando se dará solidariamente com o preponente.

Assim, caso haja falsidade intencional de demonstrações contábeis, falsos lançamentos em livros, ou qualquer tipo de ardil ou fraude, haverá a responsabilização civil solidária entre preponente e preposto contabilista ${ }^{149}$.

149 Assunto correlato ainda não bem desenvolvido na doutrina pátria, e ainda sem repercussões jurisprudenciais de relevo, é o relativo à responsabilização do auditor (ou sociedade que preste serviços de auditoria) pelos lançamentos e omissões constantes dos livros e demonstrações contábeis da sociedade 


\subsection{Repercussões comerciais da escrituração}

As repercussões comerciais da escrituração são o assunto mais debatido na doutrina, que há muito se ocupa de conferir aos lançamentos contábeis, regulares ou irregulares, a viabilidade de servirem de meio de prova, além de analisar com cuidado seu regime jurídico de sigilo.

Assim, passaremos a seguir a cuidar das repercussões comerciais, iniciando com a verificação do regime sigiloso da escrituração.

\subsubsection{Escrituração e alienação de estabelecimento}

A tradição do Direito Comercial pátrio, tirante os casos de credores trabalhistas e tributários, sempre excluiu, no trespasse do estabelecimento comercial, a responsabilidade pelo pagamento do passivo do alienante pelo adquirente, ressalvada disposição contratual expressa em sentido contrário.

Referida tradição pode ser encontrada nos dizeres de J. X. Carvalho de Mendonça que, citando em reforço a opinião de Waldemar Ferreira, leciona: "Os créditos e os débitos do vendedor, proprietário do estabelecimento comercial, não podem, entretanto, passar para o comprador sem cláusula expressa a este respeito. Tal é o nosso

auditada. O tema veio à tona diante dos vários escândalos contábeis envolvendo empresas americanas (Enron, WordCom, etc.). Nesses casos, nitidamente, a sociedade norte-americana percebeu que deveria exigir mais dos auditores que um mero parecer sobre a formalidade de lançamentos ou a compatibilidade destes com os princípios contábeis normalmente aceitos. Um dos resultados disso foi a edição da famosa Lei Sarbanes-Oxley (SOx), que exige maiores rigores contábeis das sociedades e de suas auditorias. Muito embora não venhamos a desenvolver exaustivamente o assunto neste trabalho, é importante lançar a idéia de que a responsabilização irrestrita de auditores poderá lançar risco desproporcional aos integrantes da profissão, diminuindo o número daqueles dispostos a assumi-lo e privando a sociedade de um serviço extremamente relevante. 
direito. Se, no contrato, não há referência a eles, ficam excluídos da venda. Convém observar que se o comprador adquire todo o ativo, adquire os créditos, visto se acharem nele compreendidos" ${ }^{\prime 150}$.

No entanto, o art. 1.146 traz aspecto inovador à matéria ao dispor que o adquirente do estabelecimento responde pelo pagamento dos débitos anteriores à transferência, desde que regularmente contabilizados, continuando o devedor primitivo solidariamente obrigado pelo prazo de um ano, a partir, quanto aos créditos vencidos, da publicação, e, quanto aos outros, da data do vencimento.

Assim, desde que o passivo esteja escriturado, não haverá como o adquirente se subtrair à responsabilidade pelo pagamento da dívida inerente ao estabelecimento adquirido, solidariamente (no período de um ano da publicação ou do vencimento) com o alienante e solitariamente a partir de então.

A regra acima mencionada apresenta ao mesmo tempo um aumento de responsabilidade (já que o adquirente, anteriormente, não respondia pelo passivo) e uma limitação ou garantia, uma vez que a responsabilidade do adquirente será limitada ao conteúdo da escrituração do passivo.

A razão da existência do dispositivo legal supracitado é a de que, se existe escrituração regular, com livros autenticados e formalizados perante os órgãos registrários de empresas, o adquirente do estabelecimento tem o dever de exigi-los e consultá-los para avaliar, diante de seu conteúdo, se a aquisição se apresenta vantajosa sob o ponto de vista econômico.

Se não o fizer, mesmo assim ficará responsável pelos débitos existentes diante de sua desídia.

\footnotetext{
${ }^{150}$ MENDONÇA, José Xavier Carvalho de. Tratado de Direito Comercial Brasileiro. São Paulo: Freitas Bastos, 1960. p. 155. Referido autor cita ainda decisões judiciais que excluem a responsabilidade do adquirente pelo passivo, salvo se houver cláusula expressa em contrário.
} 
Veja-se que no direito italiano a regra de sucessão é a mesma inserta no art. 1.146 do novo Código Civil. De fato, o art. 2.560 do Código Civil italiano dispõe no seguinte sentido (grifos nossos):

\section{Art. 2.560 Debiti relativi all"azienda ceduta}

L'alienante non è liberato dai debiti, inerenti all'esercizio dell'azienda ceduta, anteriori al trasferimento, se non risulta che $i$ creditori vi hanno consentito. Nel trasferimento di un'azienda commerciale (2195) risponde dei debiti suddetti anche l'acquirente dell'azienda, se essi risultano dai libri contabili obbligatori (2212 e seguenti).

\subsubsection{Sigilo da escrituração e sua necessidade}

A regra geral sobre o sigilo da escrituração comercial está insculpida no art. 1.190 do novo Código Civil (Lei n. 10.406/02), nos seguintes termos:

Art. 1.190. Ressalvados os casos previstos em lei, nenhuma autoridade, juiz ou tribunal, sob qualquer pretexto, poderá fazer ou ordenar diligência para verificar se o empresário ou a sociedade empresária observam, ou não, em seus livros e fichas, as formalidades prescritas em lei.

$\mathrm{Na}$ verdade, o que garante o Código Civil é o regime de inviolabilidade da escrituração, cuja necessidade vem demonstrada magistralmente por J. X. Carvalho de Mendonça, que assevera: "Nos livros e correspondência do comerciante acham-se gravados os traços de suas operações, a história da sua vida mercantil, já dissemos; deles constam as transações com os fornecedores e os clientes, os lucros e os prejuízos, as obrigações contraídas, as despesas domésticas e mais minuciosidades do exercício da profissão. O comerciante esforça-se por manter na maior reserva os livros $e$ a correspondência de sua casa, acentuando-se, todos os dias, a necessidade dessa 
precaução, em virtude do aumento da livre concorrência, da complexidade da vida comercial, do desenvolvimento do crédito, e ainda por exigência implícita de terceiros que com ele mantêm transações. Aos banqueiros, por exemplo, muitas operações são confiadas, especialmente as de comissão e depósito, a título implicitamente confidencial. O segredo é a alma do comércio, proclamava o Alvará de 16 de dezembro de 1756, cap. 17; ele é para o comerciante, disse também Bédarride, a alma de suas operações, o elemento essencial e indispensável ao êxito dos negócios (...) A lei garante a inviolabilidade desses livros, chegando a declarar, por cautela aliás indispensável, que a nenhuma autoridade, juiz ou tribunal, debaixo de pretexto algum, por mais especioso que seja, é lícito praticar ou ordenar qualquer diligência para examinar se o comerciante arruma ou não devidamente seus livros ou se neles tem cometido algum vício"151.

No mesmo sentido Haroldo Malheiros Duclerc Verçosa: "Os livros guardam informações extremamente importantes para o empresário, que poderiam ser utilizadas por terceiros - concorrentes ou não - para delas tirarem proveito econômico. Os antigos já diziam que 'o segredo é a alma do negócio'. Mesmo nas companhias abertas, que, por princípio, devem adotar o princípio de ampla transparência não só perante seus acionistas, mas também junto aos investidores em potencial (o mercado), o acesso às informações que podem ser tiradas a partir do exame de seus livros não é completamente livre, mas se encontra subordinado a uma determina disciplina”152.

Como ressalta este último autor, ainda nas sociedades anônimas de capital aberto, nas quais a publicidade de alguns de seus dados é imposta por lei como defesa do investidor, verifica-se que o sigilo da escrituração ainda está presente.

Se bem observarmos, a publicidade determinada pela legislação do anonimato diz respeito tão-somente às demonstrações contábeis e não à escrituração. $\mathrm{O}$ acesso às demonstrações, se e quando determinada sua publicação, deve ser amplo e irrestrito, o que não implica o acesso aos livros ou sistemas contábeis de escrituração, o que é vedado, em certas circunstâncias, até mesmo aos acionistas.

\footnotetext{
${ }^{151}$ MENDONÇA, José Xavier Carvalho de. Op. cit., 1906. p. 109.

152 VERÇOSA, Haroldo Malheiros Duclerc. Curso de Direito Comercial. São Paulo: Malheiros, 2004. p. 199.
} 
Nesse sentido, dispõe o art. 105 da Lei n. 6.404/76:

\section{Exibição dos Livros}

Art. 105. A exibição por inteiro dos livros da companhia pode ser ordenada judicialmente sempre que, a requerimento de acionistas que representem, pelo menos, $5 \%$ (cinco por cento) do capital social, sejam apontados atos violadores da lei ou do estatuto, ou haja fundada suspeita de graves irregularidades praticadas por qualquer dos órgãos da companhia.

Se bem verificarmos a lição de Modesto Carvalhosa, a possibilidade de exame irrestrito dos livros contábeis pelo sócio não se aplica às sociedades anônimas, pois "A possibilidade legal de qualquer acionista, a qualquer tempo, ter completo acesso aos livros da companhia poderia causar-lhe graves danos". Tal regra, nos dizeres do autor, se justifica, pois "Tem por finalidade evitar que tais livros fiquem a mercê de pessoas que adquiriram ações com a única finalidade de aproveitar-se delas para conhecimentos de negócios sigilosos ${ }^{\prime 153}$.

O sigilo aqui referido, entretanto, não se aplica ao membro de Conselho Fiscal, que pode, nos termos do art. 163 e incisos da Lei n. 6.404/76, ter amplo acesso aos documentos escriturados para realizar seu mister fiscalizatório, podendo, inclusive, ingressar em juízo para pleitear a exibição de livros contábeis.

\subsubsection{Regras gerais sobre o sigilo}

No que tange à disciplina da escrituração empresarial, a regra imperante é o sigilo ou a inviolabilidade do conteúdo lançado. A exceção é a publicidade, a exibição judicial ou administrativa.

${ }^{153}$ CARVALHOSA, Modesto; LATORRACA, Nilton. Op. cit., 1998. v. 2, p. 220. 
Como exceção que é, a publicidade da escrituração empresarial deve ser interpretada restritivamente. Com efeito, a norma que abre exceção a regras gerais, ou restringe direitos, só abrange os casos que especifica (exceptiones sunt strictissimae interpretationis).

Bem explica Carlos Maximiliano o motivo desse tipo de interpretação: “As disposições excepcionais são estabelecidas por motivos ou considerações particulares, contra outras normas jurídicas, ou contra o Direito comum; por isso não se estendem além dos casos e tempos que designam expressamente (...) Restrições ao uso ou posse de qualquer direito não se presumem: é isto que o preceito estabelece. Devem ressaltar dos termos da lei, ato jurídico ou frase de expositor ${ }^{\prime 154}$.

Duas questões se põem sobre o princípio da inviolabilidade da escrituração.

A primeira diz respeito à necessidade ou não de se cumprir um requisito de forma, ou seja, se as determinações excepcionais para a exibição da escrituração devem estar previstas em lei ou ato normativo com força de lei, ou se outros atos normativos hierarquicamente inferiores poderiam excepcionar a regra do art. 1.190 do Código Civil.

A segunda diz respeito ao alcance da regra do art. 1.190 , no que toca à extensão da inviolabilidade, importando saber se o sigilo da escrituração compreende também os documentos e as matérias (ainda que não constantes em meio documental) que devem obrigatoriamente, em algum momento, ser incluídos na escrituração.

Em relação à primeira indagação, entendemos que a exceção há de estar prevista em lei (em sentido formal) ou ato normativo hierarquicamente equiparado (e.g., medida provisória). Atos normativos de hierarquia inferior não podem determinar a quebra do princípio da inviolabilidade da escrituração constante do art. 1.190 do Código Civil. Isso porque, admitir referida hipótese, além de alargar em demasia os poderes da Administração (que poderia quebrar o princípio para todo e qualquer tipo de fiscalização), tornaria letra morta o estatuído no artigo supracitado, que buscou justamente tornar mais difícil o acesso aos dados escriturados.

\footnotetext{
${ }^{154}$ MAXIMILIANO, Carlos. Hermenêutica e aplicação do direito. Rio de Janeiro: Forense, 2001. p. 198.
} 
Já em relação ao segundo questionamento, devemos ressaltar que em nada adiantaria o sigilo da escrituração se este não se estendesse aos documentos e matérias que se constituem em pressuposto da primeira. Assim não fosse, fácil seria a qualquer indivíduo burlar a regra da inviolabilidade, exigindo, conquanto através de meios lícitos, a exibição da documentação que originou a escrituração empresarial, ou mesmo a revelação da matéria que irá compor esta última.

\subsubsection{Exceções à regra: exibição judicial e administrativa - Autoridades que podem ter acesso à escrituração}

Alguns limites se impõem à regra da inviolabilidade da escrituração empresarial. Como bem ressalta J. X. Carvalho de Mendonça: “A inviolabilidade dos livros comerciais não é, entretanto, absoluta. Em conflito com o direito do proprietário dos livros acham-se, algumas vezes, os interesses públicos. Esses interesses limitam a inviolabilidade do sigilo dos negócios comerciais ${ }^{\prime 155}$.

Praticamente três são as hipóteses em que o Código Civil de 2002 excepciona a inviolabilidade da escrituração: 1) exame dos livros pelas autoridades fiscalizatórias de tributos (exibição administrativa); 2) exibição judicial parcial da escrituração; 3) exibição judicial total da escrituração.

Haroldo Malheiros Duclerc Verçosa explica as hipóteses: “Em circunstâncias normais da atividade mercantil, somente os agentes fiscais podem ter acesso aos livros e documentos dos empresários, no estrito exercício de suas funções (NCC, art. 1.193). Além disso, exercendo suas funções constitucionais, as Comissões Parlamentares de Inquérito podem requerer informações e examinar livros e documentos

${ }^{155}$ MENDONÇA, José Xavier Carvalho de. Op. cit., 1906. p. 111. 
dos empresários, que digam respeito ao objeto preciso da investigação $\left(C F\right.$, art. $\left.58, \S 3^{\circ}\right)$. Esta situação, como se verifica, é excepcional (...) No regime do Código Comercial Brasileiro, esta regra era quebrada em duas hipóteses, as quais foram apropriadas no mesmo sentido pelo Código Civil/2002. Trata-se da exibição parcial e da exibição integral dos livros e documentos mercantis" $" 156$.

No presente tópico analisaremos apenas a exceção concernente à exibição administrativa da escrituração, sendo que a exibição (total ou parcial) em juízo será objeto de título autônomo.

O exame da escrituração pelas autoridades fiscais está assim disciplinado pelo Código Civil:

Art. 1.193. As restrições estabelecidas neste Capítulo ao exame da escrituração, em parte ou por inteiro, não se aplicam às autoridades fazendárias, no exercício da fiscalização do pagamento de impostos, nos termos estritos das respectivas leis especiais.

Vê-se, inicialmente, que nem todas as autoridades públicas poderão ter acesso à escrituração: somente as autoridades fazendárias quando no exercício da fiscalização do pagamento de tributos ${ }^{157}$.

Assim, autoridades que fiscalizam o cumprimento de outras normas jurídicas que não as tributárias em sentido amplo não poderão ter acesso à escrituração.

Portanto, autoridades fiscalizatórias de normas protetivas do trabalho (ressalvadas as contribuições sindicais de natureza tributária), de normas de saúde pública, ocupação e disposição do solo urbano ou rural, entre outras, não terão tais prerrogativas, sendo ilícito, a nosso ver, a exigência de apresentação da escrituração ao fiscalizado. O

\footnotetext{
${ }^{156}$ VERÇOSA, Haroldo Malheiros Duclerc. Op. cit., 2004. p. 199.

157 Apesar de sustentarmos a interpretação restritiva das normas que consubstanciam exceções às regras gerais, parece-nos que aqui o Código Civil claramente disse menos do que desejava ao fazer referência a impostos e não a tributos. Assim não fosse, estariam as autoridades proibidas de efetivar o exame da escrituração a respeito de inúmeras espécies tributárias, quais sejam, as taxas, as contribuições de melhoria, os empréstimos compulsórios e as contribuições sociais.
} 
Tribunal Regional Federal da $1^{\text {a }}$ Região também assim entendeu, como se pode verificar a seguir.

\section{Tribunal Regional Federal da Primeira Região}

Classe: REO - REMESSA EX-OFFICIO - 01121668

Processo: 199601121668 UF: PA Órgão Julgador: TERCEIRA TURMA

Data da decisão: 16/12/1997 Documento: TRF100058895

Fonte DJ DATA: 06/02/1998 PÁGINA: 193

Relator(a) JUIZ TOURINHO NETO

Decisão Por unanimidade, negar provimento à remessa.

Ementa

\section{ADMINISTRATIVO. FISCALIZAÇÃO DO TRABALHO. EXIGÊNCIA DE APRESENTAÇÃO DE LIVROS CONTÁBEIS. ATO ABUSIVO.} Afigura-se abusivo o ato do Fiscal do Trabalho, que após examinar os documentos necessários para o exame do recolhimento do FGTS e do pagamento das férias dos empregados da empresa, exige a apresentação dos livros contábeis, estranhos à matéria trabalhista.

E no inteiro teor da decisão acima citada, destaca o relator, referindo-se ao parecer da Procuradoria Geral da República, que "a exigência levada a termo pelo delegado do trabalho não encontra amparo legal. Em seu artigo 630, $\S \S 3^{\circ}$ e $4^{o}$, prevê a CLT a apresentação de 'quaisquer documentos que digam respeito ao fiel cumprimento das normas de proteção ao trabalho'. Ora, da leitura do trecho do artigo transcrito, depreende-se que a abrangência da competência do fiscal do trabalho restringe-se à fiscalização dos documentos relativos às relações laborais, não abrangendo a fiscalização tributária, que deve ser feita pelo órgão competente. Assim, uma vez apresentados os documentos comprobatórios do recebimento das guias do FGTS relativo às férias, bem como do lançamento no caixa do mês do numerário destinado ao pagamento de férias por parte da impetrante, abusiva e especulativa se tornou a requisição do fiscal do trabalho, 
no tocante à análise dos livros fiscais. Destarte, a infringência de multa por parte do referido fiscal foi praticada com abuso de poder, haja vista a falta de competência deste para fazer análise nos livros contábeis da empresa, sob o pálio de fiscalização de direitos trabalhistas. Os atos administrativos dos agentes públicos têm que observar, como condição de sua validade, a competência. No magistério de Hely Lopes Meirelles, esta é entendida como 'o poder atribuído ao agente da Administração para desempenho específico de suas funções' (MEIRELLES, Hely Lopes. Direito Administrativo Brasileiro, Editora Malheiros, $18^{a}$ edição, 1993). Vê-se, assim, não ser pertinente às funções do fiscal do trabalho o manuseio dos livros contábeis da empresa”.

Nem mesmo os Conselhos de Contabilidade, entidades públicas destinadas à fiscalização de profissões contábeis, poderão determinar a quebra de sigilo dos livros. Nesse sentido foi a decisão que transcrevemos a seguir.

\section{Tribunal Regional Federal da Quinta Região}

Classe: AMS - Apelação em Mandado de Segurança - 72554

Processo: 200005000280539 UF: CE Órgão Julgador: Primeira Turma

Data da decisão: 19/12/2002 Documento: TRF500064765

Fonte DJ - Data: 04/04/2003 - Página: 485

Relator(a) Desembargador Federal Frederico Pinto de Azevedo

Decisão UNÂNIME

Ementa

ADMINISTRATIVO. COMERCIAL. CONSELHO REGIONAL DE CONTABILIDADE. EXIGÊNCIA DE APRESENTAÇÃO DO LIVRO DIÁRIO. - A COMPETÊNCIA PARA O EXAME DOS LIVROS E DOCUMENTAÇÃO COMERCIAIS FOGE AO ÂMBITO DOS FISCAIS DO CONSELHO REGIONAL DE CONTABILIDADE, PORQUE É ATRIBUIÇÃO LEGAL DOS FISCAIS DO IMPOSTO DE RENDA. APELAÇÃO E REMESSA OFICIAL IMPROVIDAS. 
Obtendo as autoridades acesso à escrituração ao arrepio da lei, entendemos que a prova ali obtida será ilícita, não tendo qualquer valor. Além disso, a obtenção ilícita da prova contaminará as demais que dela dependam, tornando nula também eventual penalidade aplicada.

E como já salientamos antes, não aceitamos o argumento de que as exceções ao princípio da inviolabilidade da escrituração sejam impostas através de norma de hierarquia inferior à lei em sentido formal ou equivalente. Dessa forma, atos administrativos subalternos serão ilegais, por afronta aos arts. 1.190 e 1.193 do Código Civil, se assim dispuserem ${ }^{158}$.

Além disso, as autoridades fiscais tributárias terão de agir nos estritos termos da legislação que lhes dê regência, e não poderão, ao produzir prova através do acesso à escrituração, violar outras normas jurídicas que protejam o fiscalizado, sob pena de tornar a prova ilícita.

Nesse sentido, o Supremo Tribunal Federal decidiu que a prova obtida mediante acesso à documentação empresarial com violação de domicílio é ilícita, muito embora no caso concreto o exame estivesse prejudicado por falta de prova da resistência do fiscalizado.

Veja-se a ementa a seguir transcrita:

\section{Supremo Tribunal Federal}

Classe: HC - HABEAS CORPUS

Processo: 79512 UF: RJ - RIO DE JANEIRO

Fonte DJ 16-05-2003 PP-00092 EMENT VOL-02110-02 PP-00308

Relator(a) SEPÚLVEDA PERTENCE

\footnotetext{
${ }^{158}$ A Secretaria de Inspeção do Trabalho editou sobre o tema a Instrução Normativa n. 28 de 27 de fevereiro de 2002 , que em seu art. $1^{\circ}, \S 1^{\circ}$, estabelece que não se aplica aos Auditores-Fiscais do Trabalho a vedação de acesso aos livros de escrituração contábil e balanços gerais contida nos arts. 17 e 18 do Código Comercial. Entendemos que referida norma se ressente de ilegalidade em face do exposto no texto.
} 
Descrição Votação: por maioria, vencido o Ministro Marco Aurélio. Resultado: indeferido. N.PP.:(33). Análise:(MML). Revisão:(FLO). Inclusão: 22/09/03, (SVF).

EMENTA: Prova: alegação de ilicitude da obtida mediante apreensão de documentos por agentes fiscais, em escritórios de empresa - compreendidos no alcance da garantia constitucional da inviolabilidade do domicílio - e de contaminação das provas daquela derivadas: tese substancialmente correta, prejudicada no caso, entretanto, pela ausência de qualquer prova de resistência dos acusados ou de seus prepostos ao ingresso dos fiscais nas dependências da empresa ou sequer de protesto imediato contra a diligência. 1. Conforme o art. 5 XI, da Constituição - afora as exceções nele taxativamente previstas ("em caso de flagrante delito ou desastre, ou para prestar socorro") só a "determinação judicial" autoriza, e durante o dia, a entrada de alguém - autoridade ou não - no domicílio de outrem, sem o consentimento do morador. 1.1. Em conseqüência, o poder fiscalizador da administração tributária perdeu, em favor do reforço da garantia constitucional do domicílio, a prerrogativa da auto-executoriedade. 1.2. Daí não se extrai, de logo, a inconstitucionalidade superveniente ou a revogação dos preceitos infraconstitucionais de regimes precedentes que autorizam a agentes fiscais de tributos a proceder à busca domiciliar e à apreensão de papéis; essa legislação, contudo, que, sob a Carta precedente, continha em si a autorização à entrada forçada no domicílio do contribuinte, reduz-se, sob a Constituição vigente, a uma simples norma de competência para, uma vez no interior da dependência domiciliar, efetivar as diligências legalmente permitidas: o ingresso, porém, sempre que necessário vencer a oposição do morador, passou a depender de autorização judicial prévia. 1.3. Mas, é um dado elementar da incidência da garantia constitucional do domicílio o não consentimento do morador ao questionado ingresso de terceiro: malgrado a ausência da autorização judicial, só a entrada invito domino a ofende, seja o dissenso presumido, tácito ou expresso, seja a penetração ou a indevida permanência, clandestina, astuciosa ou franca. 1.4. Não supre ausência de prova da falta de autorização ao ingresso dos fiscais nas dependências da empresa o apelo à presunção de a tolerância à entrada ou à permanência dos 
agentes do Fisco ser fruto do metus publicae potestatis, ao menos nas circunstâncias do caso, em que não se trata das famigeradas "batidas" policiais no domicílio de indefesos favelados, nem sequer se demonstra a existência de protesto imediato. 2. Objeção de princípio - em relação à qual houve reserva de Ministros do Tribunal - à tese aventada de que à garantia constitucional da inadmissibilidade da prova ilícita se possa opor, com o fim de dar-lhe prevalência em nome do princípio da proporcionalidade, o interesse público na eficácia da repressão penal em geral ou, em particular, na de determinados crimes: é que, aí, foi a Constituição mesma que ponderou os valores contrapostos e optou - em prejuízo, se necessário da eficácia da persecução criminal - pelos valores fundamentais, da dignidade humana, aos quais serve de salvaguarda a proscrição da prova ilícita: de qualquer sorte - salvo em casos extremos de necessidade inadiável e incontornável - a ponderação de quaisquer interesses constitucionais oponíveis à inviolabilidade do domicílio não compete $a$ posteriori ao juiz do processo em que se pretenda introduzir ou valorizar a prova obtida na invasão ilícita, mas sim àquele a quem incumbe autorizar previamente a diligência.

\subsubsection{Escrituração como meio de prova}

A escrituração, como aspecto concernente à forma do negócio jurídico empresarial, é importante meio de prova nas questões judiciais.

A faculdade de prova do negócio jurídico mediante a apresentação da escrituração, em juízo ou mesmo fora dele, é expressamente prevista no art. 226 do novo Código Civil. Veja-se ainda que a exibição da escrituração prova tanto sobre o que nela se inseriu quanto sobre o que dela se omitiu ou não se fez inserir. 
Não haverá, entretanto, efeito probatório, quando a lei expressamente exija documento público ou particular para a prova do ato respectivo.

Duas questões são de essencial importância para serem analisadas, diferindo conforme a hipótese formulada: 1) a exibição da escrituração como prova contrária àquele que a elaborou; 2) a exibição da escrituração como prova a favor do elaborador.

Outrossim, nossa legislação também faz uma distinção para a utilização da escrituração como meio de prova quando o litígio seja entre comerciantes ou não.

Para a elaboração de prova contra o elaborador da escrituração, nossa legislação não exige qualquer requisito da escrituração. Ainda que irregular, ou seja, desprovida das formalidades intrínsecas e extrínsecas, a escrituração prova contra seu elaborador.

Equivale dizer que, nesse caso, equivale a escrituração à confissão extrajudicial do fato que se deseja provar. A presunção gerada pela prova contrária, entretanto, será relativa ou vencível, nos termos do art. 378 do CPC, a seguir transcrito:

Art. 378 - Os livros comerciais provam contra o seu autor. É lícito ao comerciante, todavia, demonstrar, por todos os meios permitidos em direito, que os lancamentos não correspondem à verdade dos fatos. (grifos nossos)

Para servir de prova a favor do elaborador, a escrituração deve se apresentar conforme os requisitos legais, quais sejam, aqueles inerentes às formalidades extrínsecas e intrínsecas exigidas. Além disso, nossa legislação exige que, para tanto, o litígio se dê entre comerciantes (ou entre empresários coletivos ou individuais).

Veja-se o art. 379 do CPC:

Art. 379 - Os livros comerciais, que preencham os requisitos exigidos por lei, provam também a favor do seu autor no litígio entre comerciantes. 
A doutrina justifica o fato de que a prova a favor do elaborador da escrituração somente opere efeito no litígio entre empresários, ante a circunstância de que, em tal caso, haveria por si uma paridade de armas: ambos empresários poderiam escriturar e contrapor suas escriturações entre si, possibilidade não existente em litígio entre empresário e não-empresário.

Fábio Ulhoa Coelho assim justifica a hipótese: "O livro empresarial não tem eficácia probatória inquestionável em favor de seu titular, quando se tratar de demanda contra não-empresário, em razão do princípio constitucional da igualdade, posto que o ordenamento jurídico não confere idêntico direito à outra parte judicial" ${ }^{\text {"159 }}$.

No caso de litígio entre empresário e não-empresário, a escrituração terá, em favor do titular, o valor de prova que antes estabelecia o art. 23 do Código Comercial, ou seja, será admitida em conjunto com outra prova, se os assentos ou lançamentos forem comprovados por algum documento, que só por si não possa fazer prova plena ${ }^{160}$.

A escrituração, da mesma forma que a confissão, será indivisível para efeito de prova (art. 380 do CPC). Não se poderá, pois, admitir parte do que foi escriturado e recusar o restante.

Não obstante, J. X. Carvalho de Mendonça estabelece importante distinção neste aspecto, exigindo a conexidade entre os lançamentos escriturados para que prevaleça a indivisibilidade. Outrossim, assevera que a indivisibilidade não impede a utilização de outros meios de prova: "Como a indivisibilidade da confissão, a dos registros ou lançamentos nos livros dos comerciantes têm trazido dificuldades práticas. A indivisibilidade prevalece em toda a extensão quando as partidas ou lançamentos achamse entre si presos por laços de conexidade. Se, porém, as partidas são distintas, separadas, ou se se referem a fatos diversos, não pode ser invocada a indivisibilidade. Exemplos: consta dos livros de um comerciante que este recebera mercadorias fiadas e pagara parte

\footnotetext{
${ }^{159}$ COELHO, Fábio Ulhoa. Manual de Direito Comercial. São Paulo: Saraiva, 2003. p. 54.

${ }^{160}$ J. X. Carvalho de Mendonça (op. cit., p. 105), nos litígios entre comerciantes ou entre comerciantes e nãocomerciantes, admitia essa mesma solução quando se tratasse de discussão sobre matéria civil e a escrituração estivesse revestida das formalidades legais. Não vemos mais função para a distinção citada, uma vez que, além de não constar do art. 379 do CPC, com a adoção da teoria da empresa pelo atual Código Civil, o Direito Civil e o Comercial experimentaram razoável aproximação em seus objetos de estudo. Dessa forma, entendemos que tudo aquilo que disser respeito à atividade do empresário e for escriturado receberá os efeitos probatórios inerentes à escrituração em geral.
} 
do preço. O credor não pode aceitar uma parte deste lançamento e recusar pura $e$ simplesmente a outra, para obter a condenação do devedor ao pagamento do preço integral. O credor, admitindo como provado o que resulta a seu favor, tem de combater com outras provas a parte do livro favorável ao adversário. • Consta dos livros que o comerciante recebera as mercadorias compradas e tomara por empréstimo certa quantia ao vendedor. Neste caso, dá-se a divisibilidade; pode o credor aceitar a primeira e negar a segunda parte do lançamento" ${ }^{\prime 161}$.

\subsubsection{Exibição judicial da escrituração}

Trataremos aqui de outra das exceções à inviolabilidade da escrituração empresarial, qual seja, a exibição judicial da escrituração.

Na exibição em juízo é que se darão os efeitos probatórios favoráveis ou contrários ao titular. Em relação ao tipo de tutela processual pleiteada pela parte, três formas são reconhecidas pela doutrina para a exibição da escrituração: 1) exibição como ação principal e autônoma; 2) exibição como meio de prova em ação que contenha outro pedido principal; 3) exibição como objeto de ação cautelar.

No primeiro caso, o fim almejado por aquele que propõe a demanda é tãosomente a exibição da escrituração, no todo ou em parte. Exibida esta, extraindo-se dela os lançamentos de interesse, esgotado estará o pedido.

Na segunda hipótese, a exibição da escrituração se dará como forma de comprovar algum fato necessário à relação das partes que litigam, sendo que, aqui, o autor tem como pretensão outra que não seja tão-somente a exibição. Tem-se, portanto, mero incidente da fase probatória. Neste caso a exibição pode ser requerida: 1) contra uma das partes; 2) contra terceiro que não seja parte no processo.

${ }^{161}$ MENDONÇA, José Xavier Carvalho de. Op. cit., 1906. p. 99-100. 
Por fim, teremos a exibição como ação cautelar, na qual se deseja a produção de prova através da exibição da escrituração, como forma de garantir a efetividade de um provimento jurisdicional futuro.

Em todos os casos, a exibição poderá ser total ou parcial, como veremos a seguir.

\subsubsection{Exibição parcial}

A exibição parcial é aquela que se dá através da apresentação da escrituração em juízo com a respectiva extração de cópias, extratos ou sumas dos lançamentos constantes.

Bem explica Fábio Ulhoa Coelho que a exibição parcial "Se destina a garantir o princípio do sigilo, resguardando da curiosidade alheia as partes da escrituração mercantil que não interessam a uma certa demanda judicial, além de, é claro, não dificultar a sua elaboração e utilização. Assim, a exibição parcial se faz por extração da suma que interessa ao juízo e restituição imediata do livro ao empresário”162.

Justamente por não importar em qualquer dificuldade de manutenção da escrituração, a exibição parcial pode ser pleiteada sempre que haja interesse de uma das partes, judicialmente reconhecido, em assunto constante dos lançamentos do empresário.

Não há, portanto, ao contrário do que se prevê para a exibição total, um rol de hipóteses taxativas nas quais tal exibição é permitida. Ao contrário, a exibição parcial é a regra geral para a apresentação judicial da escrituração, consubstanciada na Súmula 260 do Supremo Tribunal Federal ${ }^{163}$.

$\overline{{ }^{162} \text { COELHO, Fábio Ulhoa. Manual, cit., 2003. p. } 53 .}$

${ }^{163}$ O exame de livros comerciais, em ação judicial, fica limitado às transações entre os litigantes. 
Por entender que a exibição parcial dos livros se fundamenta na existência de comunhão de lançamentos, há doutrinadores que não admitem que a exibição parcial da escrituração em juízo seja requerida contra terceiros ${ }^{164}$.

\subsubsection{Exibição total}

A exibição total da escrituração é medida excepcional, por importar em desapossamento ou retenção do meio em que se efetivou durante todo o trâmite processual da ação.

De acordo com o art. 1.191 do Código Civil, o juiz só poderá autorizar a exibição integral dos livros e papéis de escrituração quando necessária para resolver questões relativas à sucessão, comunhão ou sociedade, administração ou gestão à conta de outrem, ou em caso de falência.

Da mesma forma, o art. 381 do CPC determina que o juiz pode ordenar, a requerimento da parte, a exibição integral dos livros comerciais e dos documentos do arquivo: I - na liquidação de sociedade; II - na sucessão por morte de sócio; III - quando e como determinar a lei.

A ratio essendi dos dispositivos supracitados é a comunhão de interesses no objeto da escrituração que possuem a parte requerente da exibição e aquela contra a qual essa medida é requerida.

\subsubsection{Aspectos processuais da exibição}

\footnotetext{
164 J. X. Carvalho de Mendonça (op. cit., p. 166), ressalvando as hipóteses dos corretores, por serem depositários de documentos comuns das partes contratantes.
} 
A exibição se inicia com o requerimento da parte, na petição inicial ou na fase probatória, ao serem as provas devidamente especificadas, contendo os requisitos do art. 356 do CPC.

Requerida a exibição, o juiz mandará citar (caso de exibição como ação principal, cautelar, em face de terceiro) ou intimar (no caso de a exibição ser requerida como incidente probatório) a parte contrária, que dará a sua resposta nos 5 (cinco) dias subseqüentes à sua intimação.

Apresentando a escrituração, estará encerrado o incidente, podendo ser os lançamentos ainda objeto de prova pericial contábil. Se o requerido afirmar que não possui escrituração, o juiz permitirá que o requerente prove, por qualquer meio, que a declaração não corresponde à verdade (art. 357 do CPC).

Realizada ou não a prova, deverá o juiz decidir. Admitindo a recusa (p. ex., nos casos do art. 363 do CPC), dispensará o juiz a exibição. Não a admitindo, ou se o requerido nada responder (hipóteses do art. 358 do CPC), poderá o juiz tomar uma de duas decisões: 1) se o requerido for parte no processo, presumir-se-ão verdadeiros os fatos que a parte contrária pretendia provar; 2) se o requerido for terceiro, o juiz lhe ordenará que proceda ao respectivo depósito em cartório ou noutro lugar designado, no prazo de 5 (cinco) dias, impondo ao requerente que o embolse das despesas que tiver; se o terceiro descumprir a ordem, o juiz expedirá mandado de apreensão, requisitando, se necessário, força policial, tudo sem prejuízo da responsabilidade por crime de desobediência (art. 362 do CPC).

\subsubsection{Escrituração e falência}

A escrituração tem papel primordial durante o feito falimentar. Além das conseqüências criminais (crimes falimentares ligados à escrituração), que analisaremos mais adiante, a escrituração do falido é essencial durante a falência. 
O primeiro aspecto em que se sobressai a escrituração como aspecto primordial na falência é o próprio pedido de falência com base em dados de escrituração empresarial.

No regime do Decreto-Lei n. 7.661/45 estava prevista a chamada verificação judicial de conta, que nada mais era que um pedido de exibição judicial de escrituração, seguido de perícia específica de natureza contábil e final decisão que, homologando o cálculo pericial, tornava líquido e exigível um crédito escriturado pelo devedor e/ou pelo credor em seus livros.

Assim, com base na escrituração, viabilizava-se o pedido de falência.

A Lei n. 11.101/05 não mais prevê a verificação judicial de conta para fundamentar pedido de falência. Não obstante, concordamos com o comentário da Prof ${ }^{a}$ Vera Helena de Mello Franco, para quem "A nova Lei não mais faz menção à medida cautelar de verificação de conta nos livros empresariais, antes objeto do disposto na norma do art. $1^{o}, \S 1^{o}$, do antigo Dec. Lei falimentar. A omissão, todavia, não afasta a possibilidade do pedido, cuja disciplina está estabelecida nos arts. 379 a 382 do CPC, tornando desnecessária a sua repetição no texto falimentar. Aliás, com este teor, a norma do art. 191, do CC, mantém a mesma orientação que admite a exibição integral de livros em caso de falência. Mas a verificação somente se justifica quanto inexistir título executivo previsto em lei ou quando, existindo, não houver liquidez do quantum”165.

Outro tema importante influenciado pela escrituração é a determinação do passivo falimentar. Com efeito, nas verificações de crédito, a legislação brasileira prevê há tempos o exame da escrituração do falido constante de seus livros, para o correto dimensionamento das dívidas.

O Decreto-Lei n. $7.661 / 45$ previa a confrontação, pelo síndico, das declarações de crédito apresentadas pelos credores com as informações constantes dos livros do falido, fazendo acompanhar seu parecer do extrato da conta de cada credor,

165 SOUZA JÚNIOR, Francisco Satiro de e PITOMBO, Antônio Sérgio A. de Moraes (coords.) Comentários à Lei de recuperação de empresas e falência: Lei n. 11.101/2005. São Paulo: Editora Revista dos Tribunais, 2005. p. 394. 
extraído da escrituração do falido. Além disso, deveria apresentar referido profissional, durante a verificação, a relação dos credores que não fizeram a declaração do art. 82 , mas que constem dos livros do falido.

Na legislação atual (Lei n. 11.101/05), a importância da escrituração do falido na determinação do passivo e, portanto, nas declarações de crédito, é ainda maior.

Com efeito, nos termos do art. $7^{\circ}$ e parágrafos da legislação supracitada, o administrador judicial, antes de qualquer outra providência destinada à verificação de créditos, fará publicar edital tomando por base as informações constantes dos livros contábeis e documentos comerciais e fiscais do devedor e nos documentos que lhe forem apresentados pelos credores. Saliente-se que, caso o credor não venha a apresentar divergência ou mesmo habilitação, prevalecerá, para todos os efeitos, o edital com base nas informações escrituradas do falido, que será assim incluído no quadro geral de credores.

Por esses motivos é necessário que o falido apresente sua escrituração perante o juízo falimentar ${ }^{166}$ e que esta esteja regular, possibilitando-se o exame pelo síndico e pelos credores e, na sua falta, seja viabilizada a possibilidade de constrição judicial forçada.

Não se justifica, entretanto, a exigência de escrituração para o pedido de falência requerida pelo próprio devedor, como presente no art. 105, I, da Lei n. 11.101/05. Levado à risca, o dispositivo impediria a falência do empresário irregular, o que seria verdadeiro contra-senso.

Mais uma vez é proveitoso o comentário da Prof ${ }^{a}$ Vera Helena de Mello Franco: "Lembramos que o direito anterior não excluía a possibilidade do 'comerciante irregular' confessar a própria falência, desde que, como prelecionava Miranda Valverde (...) juntasse 'prova de sua qualidade, talões ou recibos de impostos pagos para o exercício da profissão (...). Entenda-se, portanto, a autorização, para a confissão de autofalência,

\footnotetext{
166 Tanto o Decreto-Lei n. 7.661/45 quanto a Lei n. 11.101/05 determinam, como dever do falido, depositar em cartório, no ato de assinatura do termo de comparecimento, os seus livros obrigatórios, a fim de serem entregues ao administrador judicial, depois de encerrados por termos assinados pelo juiz, bem como entregar, sem demora, todos os bens, livros, papéis e documentos ao administrador judicial, indicando-lhe, para serem arrecadados, os bens que porventura tenha em poder de terceiros.
} 
como extensiva, inclusive aos empresários irregulares, tal como era a orientação do direito anterior" 167 .

Parece ser esta também a opinião de Fábio Ulhoa Coelho: "Quando o próprio devedor requerer a falência, o juiz apenas não deve decretá-la em caso de desistência tempestiva"168. O que faz entender que a ausência de apresentação da escrituração e respectivas demonstrações não deverão ser levadas em conta pelo magistrado para a decretação da quebra no caso concreto.

\subsubsection{Escrituração e concordata (recuperação judicial ou extrajudicial)}

Nas antigas concordatas e nas atuais recuperações (judiciais ou extrajudiciais) a escrituração tem papel de maior relevância ainda do que aquele presente nas falências.

Com efeito, além da apresentação dos livros obrigatórios, é requisito, para o processamento do pedido referente a tais institutos, a apresentação dos seguintes documentos:

Para as concordatas (Dec.-Lei n. 7.661/45, art. 159, § $1^{\circ}$ ):

- Demonstrações financeiras referentes ao último exercício social e as levantadas especialmente para instruir o pedido, confeccionadas com estrita observância da legislação societária aplicável e composta obrigatoriamente de:

\footnotetext{
${ }^{167}$ Op. cit., 2005. p. 394.

${ }^{168}$ COELHO, Fábio Ulhoa. Comentários à Lei de Falências e Recuperação de empresas. São Paulo: Saraiva, 2005. p. 295.
} 
- Balanço patrimonial;

- Demonstração de lucros ou prejuízos acumulados;

- Demonstração do resultado desde o último exercício social;

- Inventário de todos os bens e a relação das dívidas ativas.

Para as recuperações judiciais e extrajudiciais cuja homologação tornará o conteúdo do plano impositivo ou obrigatório aos credores dissidentes ${ }^{169}$ (Lei n. 11.101/05, arts. 51 e $163, \S 6^{\circ}$, II $)^{170}$ :

- As demonstrações contábeis relativas aos 3 (três) últimos exercícios sociais e as levantadas especialmente para instruir o pedido, confeccionadas com estrita observância da legislação societária aplicável e compostas obrigatoriamente de:

- Balanço patrimonial;

- Demonstração de resultados acumulados;

- Demonstração do resultado desde o último exercício social;

- Relatório gerencial de fluxo de caixa e de sua projeção.

\footnotetext{
${ }^{169}$ Não será necessária a apresentação das demonstrações no caso de recuperação extrajudicial consensual ou de homologação não obrigatória (art. 162 da Lei n. 11.101/05), uma vez que, estando os credores signatários previamente de acordo com o plano de recuperação e inexistindo impugnações, não haveria razão para a juntada aos autos desses relatórios contábeis.

${ }^{170}$ As demonstrações não são exigidas das microempresas e empresas de pequeno porte, como já nos referimos no texto. Estas, nos termos do art. 51, $\S 2^{\circ}$, da Lei n. 11.101/05, apresentarão os documentos exigidos pela sua legislação de regência.
} 
Verifica-se que os demonstrativos contábeis, oriundos da escrituração empresarial, são essenciais para a reorganização da empresa, sob qualquer um de seus aspectos.

Devemos aqui verificar que a legislação atual ampliou ainda mais os requisitos referentes às demonstrações contábeis, exigindo os relatórios referentes a três exercícios, além daqueles confeccionados imediatamente antes do pedido, ao contrário da norma revogada que fazia referência tão-somente ao último exercício ${ }^{171}$.

Além disso, verificamos que, ao invés de exigir, como fazia o Dec.-Lei n. 7.661/05, a demonstração de lucros e prejuízos acumulados (DLPA), a Lei n. 11.101/05 exigiu a apresentação de demonstração de resultados acumulados, a qual não é prevista na legislação societária.

Tal exigência gerou algumas perplexidades na doutrina.

A Prof ${ }^{\mathrm{a}}$. Raquel Sztajn leciona sobre o assunto: "Mas o legislador se refere a demonstrativo de resultados acumulados. Que tipo de peça contábil é essa? Aquela em que os resultados dos três períodos anuais são somados, tal como se dá com o balanço? Ou aquela em que são apresentados lado a lado para fins de confronto? Se o que se tinha em mente era somar resultados anuais, o risco é que se compute duplamente aqueles transferidos para o balanço de encerramento do exercício que, por força do processo contábil, estão, em alguma medida, refletidos no balanço inicial do ano seguinte. Se o que se pretende é que os resultados sejam apresentados lado a lado, a peça não tem utilidade, porque pode ser obtida pela só justaposição dos demonstrativos anuais ${ }^{\text {172 }}$.

Realmente, a referência do legislador causa inicialmente algumas dúvidas. Isso porque as contas de resultado acumulam valores durante algum período de tempo (normalmente um exercício), superado o qual seus valores são transferidos para uma conta única (apuração do resultado do exercício). O saldo desta última conta, por sua vez, é

\footnotetext{
${ }^{171}$ Utilizando-se de três colunas de valores em cada demonstrativo, cada qual referente a um exercício, é possível, em um único documento, apresentar os relatórios nos termos exigidos pela Lei n. 11.101/05. Essa forma melhora, inclusive, a visualização dos números, além de proporcionar imediata comparabilidade.

${ }^{172}$ Lição inserida na obra: SOUZA JÚNIOR, Francisco Satiro de e PITOMBO, Antônio Sérgio A. de Moraes (coords.). Comentários à Lei de recuperação de empresas e falência: Lei 11.101/2005. São Paulo: Editora Revista dos Tribunais, 2005. p. 251.
} 
ordinariamente transferido para a conta de lucros e prejuízos acumulados, tornando “zerados" todos os saldos das contas de resultado.

No entanto, o demonstrativo de resultados acumulados não é um desconhecido da ciência contábil ${ }^{173}$. Destina-se à hipótese aventada pela Prof ${ }^{\mathrm{a}}$. Rachel Sztajn, qual seja, à soma dos períodos em análise.

Sua utilização, porém, deve ser vista com certo cuidado, uma vez que os valores inseridos nas contas de resultado dos diversos exercícios estão em moedas de datas diferentes. Sua soma, portanto, pode gerar sérias distorções de interpretação, pois que as quantias expressas monetariamente têm diferentes valores no tempo.

Seria desejável, então, que, para os efeitos de falência, o demonstrativo de resultados acumulados fosse elaborado com observância da correção monetária integral, nos moldes anteriormente mencionados pela Instrução 191 da CVM.

Algumas outras questões se põem aqui e são a seguir formuladas:

1) Há como o juiz retirar alguma informação dos demonstrativos contábeis apresentados com o pedido de concordata ou recuperação que lhe aponte a viabilidade econômica ou o risco de determinado empresário vir posteriormente a falir?

2) Em caso positivo, poderá o juiz negar o processamento da recuperação judicial, considerando, com base nas demonstrações contábeis, que a atividade empresarial que ali se apresenta é inviável?

Há uma série de modelos estatísticos que buscam predizer a possibilidade da ocorrência de falência. Entre eles, o citado por Rashad e Khalik ${ }^{174}$ e Brigham et al. ${ }^{175}$, ambos baseados no modelo de Edward Altman de análise discriminante múltipla, tem conseguido certa primazia na doutrina.

\footnotetext{
${ }^{173}$ A utilização desse relatório pode ser vista na obra da Fundação Instituto de Pesquisas Contábeis, Atuariais e Financeiras. Aprendendo contabilidade em moeda constante. São Paulo: Atlas, 2004.

${ }^{174}$ RASHAD, A.; KHALIK, Abdel. Op. cit., 2004. p. 202.

${ }^{175}$ BRIGHAM, Eugene F. et al. Administração financeira: teoria e prática. São Paulo: Atlas, 2001. p. 942.
} 
O modelo se destina à predição de falência para período futuro aproximado de dois anos através de uma função (Z-Score), com as seguintes características:

$$
Z=0,012 X_{1}+0,014 X_{2}+0,033 X_{3}+0,006 X_{4}+0,999 X_{5}
$$

Na qual:

$\mathrm{X}_{1}$ - capital circulante/ total de ativos;

$\mathrm{X}_{2}-$ lucros acumulados/total de ativos;

$\mathrm{X}_{3}$ - lucro antes de juros e imposto sobre a renda/ativo total;

$\mathrm{X}_{4}$ - valor de mercado do patrimônio/endividamento total no balanço;

$\mathrm{X}_{5}$ - vendas/ativo total.

Os resultados do teste serão interpretados nos termos do quadro abaixo.

Quadro 35: possíveis resultados do Z-Score e sua interpretação

\begin{tabular}{|c|c|}
\hline Resultado do Z-Score & Interpretação \\
\hline $\mathrm{Z}<1,81$ & Grande probabilidade de falência \\
\hline $1,81<\mathrm{Z}<2,99$ & Zona de incerteza \\
\hline $\mathrm{Z}>2,99$ & $\begin{array}{c}\text { Reduzidas probabilidades de } \\
\text { falência }\end{array}$ \\
\hline
\end{tabular}

Façamos, portanto, um exemplo concreto, utilizando as demonstrações financeiras (balanço e demonstração de resultado) já expostas neste trabalho quando da exposição de tais relatórios. Consideraremos no cálculo as quatro primeiras variáveis $\left(\mathrm{X}_{1} \mathrm{a}\right.$ $\mathrm{X}_{4}$ ) em porcentagem e não em decimais.

Entabulando os dados do exercício de 2007, teremos:

Quadro 36: cálculo do Z-Score para exemplo anterior

\begin{tabular}{lrrr}
\hline & & \multicolumn{1}{c}{$\begin{array}{c}\text { Percentuais } \\
\text { (fórmula) }\end{array}$} & $\begin{array}{c}\text { Total das } \\
\text { parcelas }\end{array}$ \\
\hline Capital circulante & $619.600,00$ & & \\
Ativo total & $904.600,00$ & & 0,82 \\
\hline $\mathbf{X}_{\mathbf{1}}$ & 68,49 & 0,012 & \\
\hline Lucros Acumulados & $(277.000,00)$ & & \\
Total de ativo & $904.600,00$ & & \\
\hline $\mathbf{X}_{\mathbf{2}}$ & $(30,62)$ & 0,014 & \\
\hline EBIT & $(269.100,00)$ & & \\
\hline
\end{tabular}




\begin{tabular}{lrrr} 
Total de ativo & $904.600,00$ & & $(0,98)$ \\
\hline $\mathbf{X}_{\mathbf{3}}$ & $(29,75)$ & 0,033 & \\
\hline Valor de mercado patrimônio & $823.000,00$ & & 6,05 \\
Dívida total & $81.600,00$ & \\
\hline $\mathbf{X}_{\mathbf{4}}$ & $1.008,58$ & 0,006 & \\
\hline Vendas & $120.000,00$ & & 0,13 \\
Total de ativo & $904.600,00$ & 0,999 & $\mathbf{5 , 6 0}$ \\
\hline $\mathbf{X}_{\mathbf{5}}$ & 0,13 & Total (Z-Score) & \\
\hline
\end{tabular}

Verificamos, portanto, que no caso considerado, mesmo após dois anos de prejuízo contábil, as probabilidades de falência, segundo o teste de Altman, são reduzidas.

Visto o funcionamento de um dos principais modelos preditivos de falência, cumpre agora verificar a segunda questão posta anteriormente, qual seja, se o juiz poderá, com base nos dados obtidos de algum modelo desse gênero, indeferir o pedido de processamento da concordata ou recuperação.

Veja-se que, na vigência da legislação falimentar anterior à atual (Dec.-Lei n. 7.661/45), o juiz deveria, ao decidir sobre a viabilidade da concordata, examinar se o ativo da concordatária era superior a $50 \%$ de seu passivo quirografário (art. 158, II, do Dec.-Lei n. 7.661/45). Em princípio, pois, deveria o magistrado verificar as demonstrações contábeis da concordatária para concluir sobre o atendimento ou não de um requisito para o favor legal.

Já perante a legislação anterior, devemos reconhecer que havia opiniões e decisões em ambos os sentidos:

J. C. Sampaio de Lacerda, citando Valverde, no que tange ao grau de cognição do juiz quanto à avaliação e ao cotejo do ativo e passivo da concordatária nos termos do art. 158, II, do Decreto n. 7.661/45 (exigência de ativo superior em $50 \%$ ao passivo quirografário), leciona: “Inicialmente, o juiz não terá elementos para julgar se a avaliação dos bens apresentada pelo devedor corresponde ou não à realidade. Deverá, 
pois, pondera Miranda Valverde, em princípio aceitá-la, já que o elemento de boa fé é requisito de que presume existir nos atos do devedor requerente da concordata" ${ }^{176}$.

Assim, verifica-se que referidos autores negavam ao juiz a possibilidade de ingressar em uma aprofundada análise das demonstrações contábeis do requerente da concordata, mesmo para cotejar ativo e passivo constantes do balanço patrimonial.

Rubens Requião, tratando da hipótese anterior, entende que o juiz não deva simplesmente aceitar os valores constantes das demonstrações, mas determinar, conforme o caso, a melhor avaliação dos bens componentes do ativo: “O juiz zeloso, compreendendo as finalidades sociais do instituto da concordata preventiva, deve ter em grande atenção o valor real dos bens componentes do ativo, pois constituem a natural garantia do cumprimento da concordata. Se os valores forem indevidamente inflados, cabe ao juiz determinar sua avaliação, a fim de evitar equívocos e fraudes ${ }^{\prime 177}$.

Por outro lado, havia decisões que afirmam a possibilidade de intervenção do juiz, viabilizando ao magistrado indeferir o processamento da concordata pela análise das demonstrações contábeis, como se verifica a seguir:

\section{Tribunal de Justiça de São Paulo}

E M E N T A

CONCORDATA - Indeferimento, com conseqüente decretação da quebra Hipótese em que a situação econômica da agravante não permitia a concessão do favor legal - Inexistência de garantias aos credores - Falta de comprovação de que o ativo é da ordem de $50 \%$ do passivo quirografário Decisão mantida - Agravo improvido. (Agravo de Instrumento n. 62.421-4 São Paulo - $10^{\mathrm{a}}$ Câmara de Direito Privado - Relator: G. Pinheiro Franco 03.02.98 - V. U.).

\footnotetext{
${ }^{176}$ LACERDA, J. C. Sampaio de. Manual de Direito Falimentar. Rio de Janeiro: Freitas Bastos, 1978. p. 261.

${ }^{177}$ REQUIÃO, Rubens. Curso de Direito Falimentar. São Paulo: Saraiva, 1992. p. 82.
} 
Dentre as posições acima mencionadas, trazidas aqui para ilustrar a possibilidade do exame judicial da viabilidade econômica empresarial através de suas demonstrações, ficamos, em conclusão, com aquela que entende não caber nesta fase a intervenção judicial.

Primeiramente, não há como refutar os argumentos de Valverde e Sampaio de Lacerda, para quem o juiz efetivamente não dispõe de informações suficientes nesta fase. Ordinariamente, o magistrado não possui conhecimentos técnicos econômicos contábeis suficientes para tirar uma conclusão a priori sobre o tema.

Em segundo lugar, parece descabida aqui a determinação de avaliação dos bens componentes do ativo ou outras rubricas constantes das demonstrações, pois, além de não haver previsão legal, trata-se de procedimento custoso e demorado, além de haver ainda o problema da subjetividade inerente ao processo avaliatório.

Ainda que aplicasse os modelos estatísticos, também não estaria o magistrado apto a emitir um juízo de valor com razoável grau de certeza.

Verificamos que a conclusão do modelo anteriormente descrito (e dos principais modelos existentes) opera com base em probabilidades que nem sempre se mostram existentes na prática.

Além disso, basear-se tão-somente na escrituração para avaliar a viabilidade econômica de um empreendimento pode ser uma tarefa extremamente arriscada. Enfrentase, ao assim proceder, uma série de perigos, dentre os quais as limitações da própria ciência contábil (que não mensura vários bens intangíveis), a possibilidade de o devedor apresentar escrituração destorcida, entre outras mais.

Dessa forma, concluímos pela existência de modelos que possam predizer a falência com base em demonstrações contábeis (muito embora sem um grau de certeza absoluto), ao mesmo tempo que defendemos não caber qualquer utilização, pelo magistrado, de um desses modelos para, com base neles, deferir uma recuperação judicial ou negá-la (decretando a quebra). 


\subsubsection{A escrituração na dissolução de sociedade}

Outro papel importante da escrituração é na dissolução societária, parcial ou total, na qual a sociedade se vê obrigada a conferir ao(s) sócio(s) o valor patrimonial de sua participação.

Não serão discutidos aqui as causas e os tipos de dissolução possíveis, por não se enquadrarem no objetivo deste trabalho. Restringir-nos-emos, dessa forma, aos aspectos escriturais da dissolução.

O principal efeito da dissolução societária na escrituração é que, no encerramento da atividade, deixa de viger um princípio contábil aplicável durante a vida do empreendimento, qual seja o princípio da continuidade.

Como vimos, a ciência contábil adota como um de seus postulados básicos a continuidade do empreendimento (ou da entidade, como assim costumeiramente se denomina). Diante disso, pressupõe-se que a atividade empresarial terá prazo indefinido de duração.

Em virtude desse pressuposto, resta influenciado o valor econômico dos ativos e, em muitos casos, o valor ou o vencimento dos passivos, especialmente quando a extinção da entidade tem prazo determinado, previsto ou previsível.

Por pressupor a continuidade, os ativos são avaliados, em regra, por seu valor de custo e não pelo valor que realmente atingiriam se fossem postos à venda no mercado. Outrossim, os valores de passivo que constam no balanço refletem, muitas vezes, valores futuros a serem pagos, muito diferentes daquilo que seria devido caso a atividade viesse a se encerrar no momento presente. 
Bem explicam a hipótese da continuidade Iudícibus et al.: "Este princípio, que tem grande validade do ponto de vista prático, apresenta importantes conseqüências para a Contabilidade. De fato, se aceitarmos a hipótese de que a duração da empresa é indeterminada, a filosofia de avaliação a ser adotada deverá ser oposta àquela que adotaríamos no caso de liquidação da empresa, quando interessam os valores de liquidação do passivo e de realização do ativo. Trata-se de princípio muito explorado pelos defensores dos custos históricos sob a alegação de que, se os valores de realização não interessam, então devemos ater-nos ao custo" ${ }^{178 .}$

Pois bem. Visto que o postulado da continuidade não impera quando da ocorrência da dissolução societária (total ou parcial) ${ }^{179}$, a avaliação da parcela patrimonial do sócio deve se ater a outros critérios, e principalmente a realidade dos valores de liquidação do empreendimento.

Para tanto, criou-se a figura do balanço de determinação, bem explicitada por Fábio Ulhoa Coelho, que o diferencia dos demais balanços, uma vez que nele “alteram-se os critérios de apropriação de contas e avaliação de bens e direitos adotados pelo balanço ordinário, para atender a necessidade específica da sociedade, por exemplo, a de apurar os haveres de sócio falecido, expulso ou dissidente. Os bens do ativo e direitos do passivo são, então, reavaliados (a preço de mercado) ${ }^{\prime 180}$.

Portanto, na dissolução societária, será necessário levantar balanço de determinação, mediante acordo entre os sócios ou no bojo de ação judicial através de perito nomeado, em que os ativos e passivos serão reavaliados a valores de mercado, ou de liquidação.

O balanço de determinação não afetará a escrituração normal da empresa, em caso de dissolução parcial, a qual continuará a observar, em seus lançamentos

\footnotetext{
${ }^{178}$ IUDÍCIBUS, Sérgio de, et al. Contabilidade introdutória. São Paulo: Atlas, 1990. p. 266.

${ }^{179}$ A tendência da jurisprudência do Superior Tribunal de Justiça é equiparar, para efeito de apuração do valor patrimonial, as duas formas de dissolução. Com efeito, ainda na dissolução parcial, o critério de liquidação dos haveres, segundo a maioria das decisões de referida Corte, há de ser a apuração de valor de mercado, utilizando-se o balanço de determinação, como se se tratasse de dissolução total (vide REsp 35702/SP, Relator(a) Ministro WALDEMAR ZVEITER, órgão julgador terceira turma, data do julgamento 27/09/1993).

${ }^{180}$ COELHO, Fábio Ulhoa. Curso, cit., 2003. p. 95.
} 
ordinários, os critérios contábeis consentâneos com o princípio da continuidade. Tratar-seá, no caso, de uma peça contábil autônoma utilizada apenas para fins específicos ${ }^{181}$.

Algumas orientações para o levantamento do balanço de determinação constam da norma NBC T 4 do Conselho Federal de Contabilidade. Para tanto, o balanço de determinação deverá considerar, em regra, para avaliação dos ativos, o valor de mercado (ou mesmo o valor presente), e para a avaliação dos passivos, quando for o caso, o valor presente, assim conceituados:

- Valor de mercado é o preço à vista praticado, deduzido das despesas de realização e da margem de lucro. As avaliações feitas pelo valor de mercado devem ter como base transação mais recente, cotação em bolsa e outras evidências disponíveis e confiáveis.

- Valor presente é aquele que expressa o montante ajustado em função do tempo a transcorrer entre as datas da operação e do vencimento, de crédito ou obrigação de financiamento, ou de outra transação usual da entidade, mediante dedução dos encargos financeiros respectivos, com base na taxa contratada ou na taxa média de encargos financeiros, praticada no mercado.

Os valores do ativo que representam as disponibilidades terão seu valor praticamente intacto, subtraídas as despesas de realização. Os créditos e as obrigações (constantes do passivo) serão avaliados a valor presente, somados eventuais encargos. Os estoques, investimentos e imobilizado serão avaliados a valor de mercado, menos despesas de realização.

Embora seja tema cercado de polêmicas, segundo a doutrina e a jurisprudência majoritárias, deverá ser incluído no balanço de determinação o valor do

\footnotetext{
${ }^{181}$ Como também não servirá de base para a apuração de haveres a escrituração normal, nos termos da Súmula 265 do STF, sendo necessário balanço especial de determinação para a apuração dos haveres.
} 
fundo de comércio e os respectivos valores intangíveis, como aviamento (goodwill), clientela, etc. $^{182}$.

\subsubsection{Escrituração nas empresas do Novo Mercado e as práticas de boa governança corporativa}

Uma das inovações recentes praticadas no mercado foi a criação de uma categoria de Companhias participantes de um segmento especial do mercado de ações da Bolsa de Valores de São Paulo, o denominado Novo Mercado.

A participação de determinada Companhia no referido segmento, em seus diversos patamares, depende de uma série de requisitos, entre eles o atendimento de algumas normas de escrituração internacionais e a elaboração de algumas demonstrações financeiras não exigidas na Lei n. 6.404/76.

O conjunto de requisitos e normas exigidos das Companhias que negociem suas ações no Novo Mercado visa a conferir maior transparência aos investidores, pela quantidade e qualidade das informações publicadas, além de proporcionar maior uniformidade na escrituração e demonstrações, pela adoção de normas contábeis internacionais.

Entre as principais inovações inerentes à escrituração empresarial das Companhias que venham a fazer parte do Novo Mercado, nos diversos graus de classificação, constantes do regulamento de referido segmento elaborado pela BOVESPA, estão as seguintes:

- Exigência de apresentação da Demonstração dos Fluxos de Caixa (DFC). As demonstrações financeiras da Companhia e as

\footnotetext{
${ }^{182}$ Nesse sentido a observação de PENTEADO, Mauro Rodrigues. Dissolução e liquidação de sociedades. São Paulo: Saraiva, 2000.
} 
demonstrações consolidadas a serem elaboradas após o término de cada trimestre (excetuando o último trimestre) e de cada exercício social devem, obrigatoriamente, incluir Demonstração dos Fluxos de Caixa, a qual indicará, no mínimo, as alterações ocorridas no saldo de caixa e equivalentes de caixa, segregadas em fluxos das operações, dos financiamentos e dos investimentos;

- Demonstrações Financeiras elaboradas de acordo com padrões internacionais. Após o encerramento de cada exercício social a Companhia deverá, adicionalmente ao previsto na legislação vigente: (i) elaborar demonstrações financeiras ou demonstrações consolidadas, conforme previsto nos padrões internacionais IFRS ou US GAAP ${ }^{183}$, em reais ou dólares americanos, que deverão ser divulgadas na íntegra, no idioma inglês, acompanhadas do relatório da administração, de notas explicativas, que informem inclusive o lucro líquido e o patrimônio líquido apurados ao final do exercício segundo os princípios contábeis brasileiros e a proposta de destinação do resultado, e do parecer dos auditores independentes; ou (ii) divulgar, no idioma inglês, a íntegra das demonstrações financeiras, relatório da administração e notas explicativas, elaboradas de acordo com a legislação societária brasileira, acompanhadas de nota explicativa adicional que demonstre a conciliação do resultado do exercício e do patrimônio líquido apurados segundo os critérios contábeis brasileiros e segundo os padrões internacionais IFRS ou US GAAP, conforme o caso, evidenciando as principais diferenças entre os critérios contábeis aplicados, e do parecer dos auditores independentes;

- Exigência de auditoria independente e experiente. Os Auditores independentes contratados pela Companhia, além de serem registrados na CVM, deverão possuir experiência comprovada no exame de demonstrações financeiras elaboradas de acordo com os padrões

\footnotetext{
${ }^{183}$ Normas de contabilidade utilizadas nos Estados Unidos da América, conhecidas como "United States Generally Accepted Accounting Principles".
} 
internacionais IFRS ou US GAAP, conforme o caso, respondendo a Companhia pelo atendimento dessa formalidade;

- Exigência de informações trimestrais em inglês ou elaboradas de acordo com padrões internacionais. A Companhia deverá apresentar a íntegra das Informações Trimestrais traduzidas para o idioma inglês ou, então, apresentar Demonstrações Financeiras ou Demonstrações Consolidadas conforme previsto nos padrões internacionais IFRS ou US GAAP.

Quanto à demonstração de fluxos de caixa (DFC), referimo-nos em tópico específico. Não foi especificada na regulamentação da BOVESPA a metodologia da elaboração da demonstração, que ficará a cargo da Companhia.

Inovação importante, a nosso ver, foi a padronização da escrituração através da utilização de normas internacionais, o que poderá criar maior previsibilidade nas demonstrações e maior padrão de comparabilidade entre os demonstrativos de diversas Companhias.

\subsection{Irregularidade e ausência de escrituração}

Já verificamos algumas repercussões da ausência e da irregularidade de escrituração, entre elas a impossibilidade do pedido de concordata, recuperação judicial ou extrajudicial, viabilidade da tipificação de crime falimentar, além dos efeitos de prova, contrários ou favoráveis, da escrituração regular.

Cumpre aprofundar aqui um pouco mais referido tema, para sabermos quando estaremos em face de uma escrituração irregular ou ausente. É óbvio que a 
ausência total de escrituração será facilmente verificável. A ausência parcial (omissão) ou a irregularidade, nem sempre.

Em princípio, a escrituração regular pressupõe a existência dos conhecidos requisitos intrínsecos e extrínsecos.

Segundo J. X. Carvalho de Mendonça, “As formalidades extrínsecas, a que a lei sujeita os livros comerciais obrigatórios, referem-se à parte exterior desses livros e visam impedir as falsificações, supressões, adições ou substituições de suas folhas" ${ }^{184}$. Tais formalidades são basicamente aquelas previstas na Instrução Normativa do Departamento Nacional de Registro do Comércio (DNRC) n. 102, de 25 de abril de 2006, a que aludimos anteriormente

Ainda segundo o mesmo autor, "As formalidades intrínsecas a que o Código sujeita os livros comerciais obrigatórios, referem-se ao modo de escriturá-los, e têm por escopo garantir a regularidade dos lançamentos ou registros (...) As formalidades legais intrínsecas dos livros comerciais obrigatórios são: 1) individuação e clareza; 2) forma mercantil; 3) ordem cronológica; 4) registros contínuos e corretos ${ }^{\text {} 185}$.

Em relação aos requisitos extrínsecos, sua verificação quanto à regularidade ou ausência é de maior facilidade, uma vez que a mera observação, ainda que feita por pessoa não especialista no assunto, poderá facilmente detectá-las.

Já em relação aos requisitos intrínsecos, o exame deve ser feito com maior acurácia e já pressupõe um observador que conheça com certa profundidade a matéria.

Mas não terminam por aí os problemas inerentes à irregularidade ou omissão de escrituração. De fato, além dos requisitos formais (intrínsecos e extrínsecos), há de ser analisado o mérito da escrituração, ou seja, o evento econômico escriturado.

Sobre este último aspecto, a omissão ou irregularidade na escrituração poderá ter vários motivos e ser determinada por vários antecedentes fáticos.

\footnotetext{
${ }^{184}$ MENDONÇA, José Xavier Carvalho de. Op. cit., 1906. p. 37.

${ }^{185}$ Op. cit., p. 41-3.
} 
Grosso modo, faremos aqui a análise de algumas das principais causas de omissão ou irregularidade na escrituração: 1) a limitação de métodos e divergência de critérios; 2) os erros e fraudes.

\subsubsection{Irregularidade ou omissão por diferença de critérios contábeis e limitação de métodos}

Há, por certo, uma série de limitações à matéria que pode ser escriturada. Fazendo uso da ciência contábil como base, a escrituração empresarial sofre as restrições inerentes a esta.

Uma das principais limitações da contabilização de eventos econômicos é que somente são lançados os fatos que possam ser objetivamente mensurados em moeda. Dessa forma, não são registrados valores de marcas próprias, valor da tecnologia ou da qualidade dos funcionários, valorização decorrente da localização geográfica de estabelecimentos, etc.

Outra limitação é dada pela adoção de critérios conservadores, como por exemplo a utilização dos custos históricos para avaliação de ativos, o que não é necessariamente verdade em todos os casos.

A contabilidade, além disso, apresenta poucas informações qualitativas. Ao visualizarmos a escrituração ou os demonstrativos dela retirados, não saberemos informar na maioria das vezes, por exemplo, o prazo de vencimento das obrigações constantes do passivo, ou como anda a aceitação do mercado para os produtos vendidos, entre outras informações.

Por fim - e com maior importância -, salienta-se a existência de grandes divergências entre os critérios contábeis para a escrituração de determinados eventos. 
Como exemplo, podemos citar a avaliação de estoques, para a qual podem ser utilizados os critérios vistos de PEPS, UEPS, preço específico ou média ponderada móvel. Igualmente para a avaliação dos custos de produção, podendo ser aplicados critérios de custeio por absorção, variável, baseado em atividades, etc.

A utilização de critérios diversos para a escrituração de um mesmo fato econômico pode gerar sérias distorções e prejuízo para a comparabilidade dos demonstrativos de empresas.

As divergências de critérios ainda são, muitas vezes, consagradas por legislação específica. Vide, por exemplo, a questão dos juros sobre capital próprio, anteriormente aludida neste trabalho, que deve ser demonstrada segundo um critério para o fisco e outro para a CVM.

É mister, portanto, que se uniformizem critérios contábeis, para maior transparência da escrituração e demonstrativos.

\subsubsection{Irregularidade por erros e fraudes}

Além das limitações de métodos e divergências de critérios, a irregularidade na escrituração pode se dar por erros e fraudes na sua elaboração.

Assim, é necessário explicitar e delimitar os conceitos de erro e fraude para efeito de escrituração. Para todos os efeitos, tomaremos emprestadas as definições da norma NBC T 11 do Conselho Federal de Contabilidade, que transcrevemos a seguir ${ }^{186}$ :

\footnotetext{
${ }^{186}$ Saliente-se que a existência de erro ou fraude, sendo o primeiro derivado de culpa e a segunda de dolo, irá influenciar seriamente na forma de responsabilização do profissional de contabilidade, nos termos do novo Código Civil.
} 
- O termo erro refere-se a ato não-intencional na elaboração de registros e demonstrações contábeis, que resulte em incorreções deles, consistente em: a) erros aritméticos na escrituração contábil ou nas demonstrações contábeis; b) aplicação incorreta das normas contábeis; e c) interpretação errada das variações patrimoniais.

- O termo fraude refere-se a ato intencional de omissão ou manipulação de transações, adulteração de documentos, registros e demonstrações contábeis. A fraude pode ser caracterizada por: a) manipulação, falsificação ou alteração de registros ou documentos, de modo a modificar os registros de ativos, passivos e resultados; b) apropriação indébita de ativos; c) supressão ou omissão de transações nos registros contábeis; d) registro de transações sem comprovação; e e) aplicação de práticas contábeis indevidas.

Quando haja necessidade de auditoria, a norma supracitada, apesar de excluir a responsabilidade do auditor pela prevenção de fraudes ou erros, determina que este deva avaliar criticamente o sistema contábil, incluindo o controle interno, tanto em termos de concepção quanto de funcionamento efetivo, concedendo especial atenção às condições ou eventos que representem aumento de risco de fraude ou erro, que incluem: a) estrutura ou atuação inadequada da administração da entidade auditada ou de algum dos seus membros; b) pressões internas e externas; c) transações que pareçam anormais; d) problemas internos no cumprimento dos trabalhos de auditoria; e) fatores específicos no ambiente de sistemas de informação computadorizados.

Segundo a NBC T 11, se o auditor concluir que a fraude e/ou erro têm efeito relevante sobre as demonstrações contábeis, e que isso não foi apropriadamente refletido ou corrigido, ele deve emitir seu parecer com ressalva ou com opinião adversa.

Entretanto, quando o sistema contábil não estiver sujeito a auditoria (e.g., em sociedades por cotas de responsabilidade limitada), não há, na maioria das vezes, oportunidade para a descoberta de erros ou fraudes contábeis, ficando as raras hipóteses 
para tanto a cargo do fisco ou em caso de perícia contábil determinada judicialmente em hipóteses de litígio societário ou falência.

Isso possibilita ainda, infelizmente, a existência de uma ampla gama de procedimentos de escrituração irregulares (ou mesmo fraudulentos), o que acaba por diluir a confiança pública nos processos escriturais e demonstrativos, além da conseqüência daí derivada, qual seja, o maior custo de captação de recursos.

Algumas das principais fraudes são relatadas pela doutrina e resumidas no quadro seguinte:

Quadro 37: principais tipos de fraude segundo a doutrina especializada ${ }^{187}$

\begin{tabular}{|c|c|}
\hline $\begin{array}{c}\text { Elemento das } \\
\text { demonstrações a que se } \\
\text { refere }\end{array}$ & Descrição \\
\hline \multirow{6}{*}{ Caixa } & $\begin{array}{l}\text { Movimentos fraudulentos em dinheiro sem comprovação } \\
\text { bancária }\end{array}$ \\
\hline & $\begin{array}{l}\text { Pagamento de despesas pessoais de sócios com o caixa da } \\
\text { sociedade, violando o princípio da entidade }\end{array}$ \\
\hline & Fraude em vales e retiradas de numerário \\
\hline & $\begin{array}{c}\text { Subtrações de numerário com substituição por títulos falsos } \\
\text { ou sem valor }\end{array}$ \\
\hline & $\begin{array}{l}\text { Recebimento de valores no caixa sem contabilização (“caixa } \\
\text { dois") e criação de passivos fictícios }\end{array}$ \\
\hline & Pagamentos a empregados fantasmas \\
\hline \multirow{4}{*}{ Estoques } & Avaliação fraudulenta de valores de estoque \\
\hline & Estoque sem comprovação por documento idôneo \\
\hline & Desvios em quantidade e qualidade de bens do estoque \\
\hline & Fraudes em sucatas e refugos \\
\hline \multirow{4}{*}{ Contas a receber } & Baixa indevida em títulos a receber \\
\hline & $\begin{array}{l}\text { Recebimentos fraudulentos de clientes em lugar da pessoa } \\
\text { jurídica credora, em concurso com fraude documental }\end{array}$ \\
\hline & Fraude em devolução de bens vinculados a contas a receber \\
\hline & $\begin{array}{l}\text { Apropriação fraudulenta de valores de multas por atraso } \\
\text { devidas por clientes }\end{array}$ \\
\hline \multirow{5}{*}{ Ativo permanente } & Investimentos fictícios em imobilizado \\
\hline & $\begin{array}{l}\text { Aumento ou diminuição indevida de cotas de depreciação, } \\
\text { amortização ou exaustão }\end{array}$ \\
\hline & Reavaliações fraudulentas \\
\hline & $\begin{array}{c}\text { Contabilização de despesas em lugar de ativação no } \\
\text { imobilizado }\end{array}$ \\
\hline & Trocas ruinosas de imobilizado \\
\hline
\end{tabular}

${ }^{187}$ SÁ, Antônio Lopes de; HOOG, Wilson Alberto Zappa. Op. cit., 2005. 


\begin{tabular}{|c|c|}
\hline & $\begin{array}{l}\text { Contabilização fraudulenta de gastos em pesquisa e } \\
\text { desenvolvimento }\end{array}$ \\
\hline \multirow{4}{*}{ Passivo } & Passivo fictício \\
\hline & $\begin{array}{c}\text { Contabilização fraudulenta de datas com o fim de vantagens } \\
\text { indevidas }\end{array}$ \\
\hline & Dupla contabilização de passivos \\
\hline & Contabilização parcial de dívidas \\
\hline \multirow{3}{*}{ Patrimônio líquido } & Integralização com imobilizado obsoleto a valor irreal \\
\hline & Contabilização a maior de valores em conta de capital social \\
\hline & $\begin{array}{c}\text { Criação de falsas reservas por doação de valores fictícios ou } \\
\text { reavaliações fraudulentas }\end{array}$ \\
\hline
\end{tabular}

As principais consequiências jurídicas das fraudes acima apontadas são:

- Responsabilização civil da pessoa jurídica e dos autores (sócios, empregados, contadores ou terceiros) pelos prejuízos causados;

- Responsabilização criminal das pessoas físicas citadas por delito de falsidade material (art. 297 do CP), ideológica (art. 299 do CP), estelionato e outras fraudes (art. 171 e ss. do CP), além de sonegação fiscal (Lei n. 8.137/90) e crime falimentar (v.g. contabilidade paralela, omissão de escrituração, etc.) no caso de haver recuperação ou falência;

- Arbitramento tributário com base nos valores sonegados, efetivamente apurados ou presumidos pelo fisco, normalmente acompanhado de multa agravada pela fraude ${ }^{188}$.

Além dos procedimentos fraudulentos propriamente ditos, uma das formas mais utilizadas nos dias de hoje, que se situa na maior parte das vezes no limiar da fraude contábil, mas sem caracterizar propriamente esta figura, é o que os professores Ariovaldo dos Santos e Ivan Ricardo Guevara Grateron ${ }^{189}$ chamam de "contabilidade criativa"190.

\footnotetext{
${ }^{188}$ Exemplificativamente, a legislação de imposto de renda chega a percentuais de multa de $150 \%$ quando descoberta fraude ou sonegação.

${ }^{189}$ SANTOS, Ariovaldo dos; GRATERON, Ivan Ricardo Guevara. Contabilidade Criativa e responsabilidade dos auditores. Revista Contabilidade \& Finanças - USP, São Paulo, n. 32, p. 7-22, maio/ago. 2003.
} 
Segundo os autores citados, o termo "contabilidade criativa" é conceituado como "O processo mediante o qual os contadores aplicam os conhecimentos da norma contábil para manipular, de acordo com sua conveniência, os valores das demonstrações contábeis (...) GRIFFITHS (1998) citado por LAINEZ (1999, p. 17) apresenta a contabilidade criativa entre o que é legal e o que é ético; entre a criatividade e a fraude contábil”.

A possibilidade da utilização dos processos “criativos" em contabilidade é causada, segundo os autores, por uma série de fatores, entre os quais: 1) a existência de regras e critérios vagos, inexatos, que permitem interpretações divergentes; 2) ausência de normas regulando determinadas matérias; 3) flexibilidade e subjetividade de normas contábeis; 4) dificuldade de percepção por parte de auditores e usuários do sistema de escrituração.

Ainda segundo os professores, a utilização de práticas "criativas" em matéria escritural tem causado sérios prejuízos, entre eles os recentes escândalos contábeis envolvendo sociedades empresárias internacionais (Enron, WorldCom, etc.), além de alguns outros efeitos normalmente pretendidos pelos elaboradores: 1) benefícios indevidos na margem de vendas; 2) incentivos fiscais; 3) controle de dividendos; 4) melhoria na imagem institucional, etc.

Para a melhoria de referido quadro, de difícil erradicação, recomendam os autores que: 1) seja incrementada a responsabilidade da auditoria, que deverá se manifestar especificamente sobre a existência ou não de "contabilidade criativa"; 2) haja melhoria na normatização e harmonização contábil, reduzindo alternativas de escolha entre princípios e práticas $^{191}$.

190 Tais processos têm chamado a atenção da doutrina contábil em diversos países, como denunciam RASHAD, A.; KHALIK, Abdel. Op. cit., 2004. Segundo os autores, o "gerenciamento de lucros contábeis managing accounting earnings" "refere-se à manipulação proposital que resulta na alteração de números contábeis relatados. Essa definição inclui a noção de suavizar o resultado em torno de algum nível 'normal', bem como as escolhas contábeis dos gestores que beneficiam eles próprios ou acionistas às custas de outros reivindicantes. Entretanto, exclui o relatório 'fraudulento' e está restrito à amplitude fornecida pelos Princípios de Contabilidade Geralmente Aceitos (PCGA)”.

${ }^{191}$ A padronização contábil, muito embora sustentada por grande parte da doutrina, também é objeto de divergências. Para alguns autores, existiria a necessidade de se garantir certa margem de discricionariedade para os administradores informarem aos destinatários da contabilidade sobre aspectos relevantes e peculiares da atividade empresarial. Se determinada a padronização global, ocorreria um engessamento da contabilidade 


\subsection{A ausência de escrituração derivada de extravio ou perda}

Devemos verificar ainda a ausência total ou parcial de escrituração por extravio ou perda de seus meios de armazenamento ou guarda.

Em princípio e como regra geral, todo e qualquer empresário deve guardar a escrituração efetuada e os documentos que lhe deram base até a prescrição das obrigações nela constantes. Isso é o que declara o art. 1.194 do Código Civil, a seguir transcrito.

Art. 1.194. O empresário e a sociedade empresária são obrigados a conservar em boa guarda toda a escrituração, correspondência e mais papéis concernentes à sua atividade, enquanto não ocorrer prescrição ou decadência no tocante aos atos neles consignados ${ }^{192}$.

A perda ou extravio, total ou parcial, da escrituração empresarial deve sempre ser sucedida de publicidade, para que se faça prova da boa-fé de seu titular.

Assim é que dispõe a Instrução Normativa do Departamento Nacional de Registro do Comércio (DNRC) n. 102, de 25 de abril de 2006, a seguir transcrita.

Art. 18. Ocorrendo extravio, deterioração ou destruição de qualquer dos instrumentos de escrituração, o empresário ou a sociedade empresária fará

como forma de os gestores revelarem ao mercado particularidades econômicas da atividade. A padronização, portanto, resultaria em prejuízo ao conteúdo informativo da contabilidade, dificultando seu papel de reduzir assimetrias informacionais e reduzindo a comparabilidade dos dados. Defendendo tal postura o trabalho de LOPES, Alexsandro Broedel; MARTINS, Eliseu. Teoria da Contabilidade: uma nova abordagem. São Paulo: Atlas, 2005.

${ }^{192}$ Veja-se que o Código Civil Italiano é mais preciso na indicação do tempo de guarda da escrituração contábil, determinando sua conservação por dez anos do último registro, nos seguintes termos: “Art. 2220 Conservazione delle scritture contabili. Le scritture devono essere conservate per dieci anni dalla data dell'ultima registrazione (2312).Per lo stesso periodo devono conservarsi le fatture, le lettere e i telegrammi ricevuti e le co pie delle fatture, delle lettere e dei telegrammi spediti. Le scritture e documenti di cui al presente articolo possono essere conservati sotto forma di registrazioni su supporti di immagini, sempre che le registrazioni corrispondano ai documenti e possano in ogni momento essere rese leggibili con mezzi messi a disposizione dal soggetto che utilizza detti supporti”. 
publicar, em jornal de grande circulação do local de seu estabelecimento, aviso concernente ao fato e deste fará minuciosa informação, dentro de quarenta e oito horas à Junta Comercial de sua jurisdição.

$\S 1^{o}$ Recomposta a escrituração, o novo instrumento receberá o mesmo número de ordem do substituído, devendo o termo de autenticação ressalvar, expressamente, a ocorrência comunicada.

$\S 2^{\circ}$ A autenticação de novo instrumento de escrituração só será procedida após o cumprimento do disposto no caput deste artigo.

Não comunicando publicamente o extravio de sua escrituração, nem comunicando o fato à Junta Comercial, suportará o empresário ou a sociedade empresária os efeitos da ausência de escrituração (condenação por crime falimentar, impossibilidade de pleitear concordata e recuperação, ineficácia probatória favorável, eficácia desfavorável, etc.).

\subsubsection{A ausência de escrituração perante as autoridades fiscais}

Caso a omissão ou irregularidade da escrituração se verifique por fiscalização das autoridades no exercício de atividade de cobrança de tributos, teremos praticamente duas conseqüências possíveis.

Primeiramente, a escrituração para o Direito Tributário possui natureza de obrigação acessória, necessária que é, junto com outras provas, à verificação da ocorrência de fatos geradores de tributos. 
Assim, se o sujeito passivo da obrigação tributária acessória não mantém escrituração, ou a mantém irregular a ponto de não possibilitar à autoridade fiscalizatória o exercício de sua atividade precípua, estará cometendo uma irregularidade passível de multa fiscal.

Além disso, por inviabilizar, quase sempre, a correta dimensão do(s) fato(s) gerador(es) tributário(s), sujeitar-se-á o empresário ou sociedade ao arbitramento do tributo.

Nesse sentido, podemos verificar:

\section{Tribunal Regional Federal da Segunda Região}

Classe: EDAC - EMBARGOS DE DECLARAÇÃO NA APELAÇÃO CÍVEL - 129189

Processo: 9702007070 UF: RJ Órgão Julgador: QUINTA TURMA

Data da decisão: 14/12/2004 Documento: TRF200134517

Fonte DJU DATA: 05/01/2005 PÁGINA: 47

Relator(a) JUIZ GUILHERME CALMON NOGUEIRA DA GAMA

Decisão: A Turma, por unanimidade, negou provimento aos Embargos de Declaração, nos termos do voto do(a) Relator(a).

Ementa DIREITO PROCESSUAL CIVIL E TRIBUTÁRIO. EMBARGOS À EXECUÇÃO FISCAL. LANÇAMENTO POR ARBITRAMENTO. EMBARGANTE AUTUADA POR IRREGULARIDADE DOS LIVROS FISCAIS DE SUA EMPRESA. EMBARGOS DE DECLARAÇÃO. INEXISTÊNCIA DE OMISSÃO.

1 - O recurso em tela é cabível quando verificada a ocorrência, na decisão impugnada, de qualquer dos vícios constantes dos incisos I e II, do artigo 535, do CPC. Sendo assim, é imprescindível que o decisum seja obscuro, contraditório ou omisso. 
2 - Por outro lado, segundo o disposto no artigo 131 do CPC, não está obrigado o Magistrado a julgar a questão posta a seu exame de acordo com o pleiteado pelas partes, mas, sim, com o seu livre convencimento, utilizando-se dos fatos, provas, jurisprudência, aspectos pertinentes ao tema e da legislação que entender aplicável ao caso concreto.

3 - No caso em questão, inexiste omissão quanto à questão da tributação reflexa no v. acórdão embargado, o qual, mantendo a sentença de primeiro grau que decidiu pela improcedência dos embargos à execução, utilizou os fundamentos que considerou suficientes para a solução da demanda, quais sejam, a insuficiência de informações colhidas na escrituração contábil apresentada, bem como pela ausência de justificativa do embargante diante de tais irregularidades, considerando regular o auto de infração, bem como a aplicação de multa e o lançamento por arbitramento de lucros.

4 - Nesse sentido, coaduna-se com a orientação do Supremo Tribunal Federal, segundo a qual "não está o juiz obrigado a examinar um a um os pretensos fundamentos das partes, nem todas as alegações que produzem: o importante é que indique o fundamento suficiente de sua conclusão, que lhe apoiou a convicção no decidir" (RE 97.558/GO).

5 - Considerando que a omissão, em matéria de embargos de declaração, é a falta de manifestação do julgador sobre pontos a respeito dos quais era fundamental o pronunciamento do julgador, verifica-se que a inconformidade da Embargante representa apenas contrariedade à orientação jurídica que se adotou no acórdão.

6 - Embargos de Declaração conhecidos, mas improvidos.

Normalmente, em hipóteses tais, as normas tributárias costumam ainda prever um incremento no valor da multa que acompanha o lançamento do tributo, por se tratar de espécie de sonegação intencional. 
Caberá ao contribuinte, na maior parte das vezes, apenas questionar em juízo os valores de multa cobrados ou os critérios para arbitramento do tributo devido.

\subsection{Repercussões criminais da escrituração}

Cabe agora verificar as principais repercussões criminais da escrituração empresarial, de sua ausência ou irregularidade. Os crimes que a doutrina mais comumente aponta envolvendo escrituração são os delitos falimentares

Como já citamos anteriormente, tais delitos são definidos da seguinte forma:

Os crimes falimentares que dizem respeito à omissão ou inexatidão da escrituração, nos termos da legislação de regência em cada época, contêm a seguinte redação:

Decreto-Lei n. 7.661, de 21 de junho de 1945:

Art. 186. Será punido o devedor com detenção, de 6 (seis) meses a 3 (três) anos, quando concorrer com a falência algum dos seguintes fatos:

VI - inexistência dos livros obrigatórios ou sua escrituração atrasada, lacunosa, defeituosa ou confusa;

VII - falta de apresentação do balanço, dentro de 60 (sessenta) dias após a data fixada para o seu encerramento, a rubrica do juiz sob cuja jurisdição estiver o seu estabelecimento principal. 
Parágrafo único. Fica isento da pena, nos casos dos ns. VI e VII deste artigo, o devedor que, a critério do juiz da falência, tiver instrução insuficiente e explorar comércio exíguo.

\section{Lei n. 11.101, de 9 de fevereiro de 2005:}

\section{Omissão dos documentos contábeis obrigatórios.}

Art. 178. Deixar de elaborar, escriturar ou autenticar, antes ou depois da sentença que decretar a falência, conceder a recuperação judicial ou homologar o plano de recuperação extrajudicial, os documentos de escrituração contábil obrigatórios:

Pena - detenção, de 1 (um) a 2 (dois) anos, e multa, se o fato não constitui crime mais grave.

Em relação ao tipo penal do art. 186, IV, cuja existência se destinava a garantir a veracidade dos dados escriturados, acreditamos tenha havido abolitio criminis, ou seja, tenha tal figura penal sido suprimida pela legislação falimentar que a sucedeu (Lei n. 11.101/05), que já não considera crime tal fato.

Assim sendo, deverá ser extinta a punibilidade do autor de referido crime falimentar, nos autos que estejam em curso e mesmo naqueles casos em que já houver condenação criminal transitada em julgado, uma vez que a abolitio criminis tem efeito retroativo.

Os tipos penais do art. 186, VI, do Decreto-Lei n. 7.661/45 e do art. 178 da Lei n. 11.101/05 praticamente se equivalem, tirante algumas diferenças sutis. De fato, o tipo penal do art. 178 da atual lei falimentar é mais amplo, abrangendo, além da escrituração propriamente dita, os documentos que lhe servem de base.

Ambos, entretanto, referem-se à omissão ou irregularidade na escrituração determinada pela legislação (comercial, fiscal ou de outra natureza) como obrigatória. 
Protegem o mesmo objeto jurídico, qual seja, a regularidade escritural para completa e cabal informação do juiz e dos credores sobre a atividade do falido.

Dessa forma, servem para este último tipo penal as principais lições da doutrina em relação àquele tipo incriminador constante da legislação falimentar revogada.

Poderão responder pelo delito, como sujeitos ativos, os sócios gerentes ou administradores (se ao tempo do fato ostentavam tal condição), além de terceiros participantes, dentre os quais ressalta a figura do profissional de contabilidade.

Diverge-se se a omissão ou irregularidade da escrituração é punida a título de culpa ou dolo. Trajano de Miranda Valverde anotava em comentário ao art. 186 do Dec.-Lei n. 7.661/45 que "De quanto fica exposto se conclui que todos os fatos enumerados no artigo revelam uma ação ou omissão culposa do devedor. $O$ dolo raramente poderá ser atribuído ao devedor. São fatos que infringem, principalmente, deveres que disciplinam a profissão de comerciante" ${ }^{193}$.

Outros entendem que se trata de crime doloso, punido a título de perigo ou mesmo de mera conduta ${ }^{194}$. Isso influiria, em princípio, na figura da tentativa. Entendido como culposo, a figura da tentativa será impossível. Mas, mesmo que entendido como doloso, por ser de mera conduta, também será inadmissível referida figura.

Outro dissenso diz respeito à circunstância de ser necessário ou não para a tipificação do crime que a ausência ou irregularidade de escrituração tenha concorrido para a quebra (ou para a recuperação judicial ou extrajudicial após a vigência da Lei n. $11.101 / 05)$, sendo que a maioria entende seja tal circunstância desnecessária ${ }^{195}$.

Na Lei n. 11.101/05, a omissão ou irregularidade é tipificada não só como crime autônomo, mas também como causa de aumento de pena do delito do art. 168 (prática de atos fraudulentos). A pena será aumentada de 1/6 (um sexto) a 1/3 (um terço), se o agente: I - elabora escrituração contábil ou balanço com dados inexatos; II - omite, na

\footnotetext{
${ }^{193}$ VALVERDE, Trajano de Miranda. Comentários à lei de falências. Rio de Janeiro: Forense, 1962. p. 62.

${ }^{194}$ Nesse sentido a decisão inserta na RJTJSP 112/479, relator Weiss de Andrade.

195 Veja-se RTJSP 114/479, relator Jarbas Mazzoni.
} 
escrituração contábil ou no balanço, lançamento que deles deveria constar, ou altera escrituração ou balanço verdadeiros; III - destrói, apaga ou corrompe dados contábeis ou negociais armazenados em computador ou sistema informatizado; ou (...) V - destrói, oculta ou inutiliza, total ou parcialmente, os documentos de escrituração contábil obrigatórios. No mesmo caso, por efeito do $\S 2^{\circ}$ do artigo mencionado, a pena é aumentada de 1/3 (um terço) até metade se o devedor manteve ou movimentou recursos ou valores paralelamente à contabilidade exigida pela legislação.

Além dos crimes falimentares que envolvem escrituração, há também outros tipos penais que a ela fazem referência.

O Código Penal, nesses termos, equipara os livros mercantis ao documento público, para fins de crime de falsidade (art. 297, $\S 2^{\circ}$, do CP). Outrossim, no inciso III do $\S 3^{\circ}$ e no $\S 4^{\circ}$ do mesmo artigo, incrimina-se com a mesma pena quem, em documento contábil ou em qualquer outro documento relacionado com as obrigações da empresa perante a previdência social, insere ou faz inserir declaração falsa ou diversa da que deveria ter constado, bem como aquele que omite, nos documentos mencionados no $\S 3^{\circ}$, nome do segurado e seus dados pessoais, a remuneração, a vigência do contrato de trabalho ou de prestação de serviços.

A Lei n. 8.137/90, sem seu art. $1^{\circ}$, II, também tipifica como crime a ação de quem, visando a suprimir ou reduzir tributo, frauda a fiscalização tributária, inserindo elementos inexatos, ou omitindo operação de qualquer natureza, em documento ou livro exigido pela lei fiscal. Em seu art. $2^{\circ}, \mathrm{V}$, incrimina quem, com o mesmo fim, utiliza ou divulga programa de processamento de dados que permita ao sujeito passivo da obrigação tributária possuir informação contábil diversa daquela que é, por lei, fornecida à Fazenda Pública.

Por fim, a Lei n. 7.492/86 tipifica em seu art. 10 a conduta de quem faz inserir elemento falso ou omitir elemento exigido pela legislação, em demonstrativos contábeis de instituição financeira, seguradora ou instituição integrante do sistema de distribuição de títulos de valores mobiliários. Além disso, define em seu art. 11 o crime consistente em manter ou movimentar recurso ou valor paralelamente à contabilidade exigida pela legislação. 


\section{CONCLUSÕES}

A escrituração empresarial, aqui analisada nos aspectos que interage com a ciência contábil, é tema necessariamente multidisciplinar. Envolve conhecimentos contábeis em sua elaboração, mas também jurídicos, na medida em que produz grandes repercussões no mundo do Direito.

Cada vez mais, portanto, o trabalho do jurista e do operador jurídico em geral (principalmente aqueles que lidam com o Direito Comercial) deverá abranger uma maior gama de conhecimentos que extrapolam seu ramo do conhecimento para a melhor adaptação aos casos concretos.

A natureza jurídica da escrituração, arte que se distingue da Contabilidade, enquanto ciência, foi tratada aqui como elemento inerente à forma do negócio jurídico, podendo assumir caráter de formalidade destinada meramente à prova, ou mesmo se tornar elemento essencial do negócio representado.

A escrita empresarial, mercantil ou comercial se distingue ainda da escrita fiscal. Trabalham ambas sobre o mesmo substrato, qual seja, os fatos econômicos provindos da atividade da empresa. No entanto, o enfoque das legislações comercial e fiscal é essencialmente diferente, principalmente ao considerarmos a atitude ostensivamente arrecadatória desta última. Tais divergências ainda causam uma série de perplexidades nos operadores, por tratarem uma mesma realidade de modo, muitas vezes, substancialmente diverso.

Diante dessa realidade, as sociedades empresariais (e mesmo os empresários individuais) têm de conviver com diversos regimes de escrituração, causando maiores complexidades e, como não poderia deixar de ser, aumento de custos de transação. $\mathrm{O}$ Direito Comercial, na esteira da situação ora descrita, tem suas próprias regras de escrituração, que não são afetadas, salvo concessões feitas por este ramo jurídico, pelas determinações advindas da legislação tributária. 
A escrituração das sociedades anônimas toma por base o disposto na Lei n. 6.404/76, a qual, apesar de se constituir em legislação especial, acaba por trazer substratos contábeis teóricos primordiais, que acabam por se aplicar a outros tipos societários. Assim, a organização das contas em grupos (ativos e passivos circulantes, de longo prazo, patrimônio líquido, etc.) vem também a se aplicar a sociedades por cotas de responsabilidade limitada, até mesmo por se invocar sua aplicação subsidiária ao Código Civil.

Nosso novo Código Civil (Lei n. 10.406/2002), passando a disciplinar a escrituração empresarial, cometeu uma série de equívocos contábeis, principalmente por repetir, de forma simplista, os dispositivos da legislação que regulava anteriormente as sociedades por ações (Decreto-Lei n. 2.627 de 26 de setembro de 1940). Alguns dos equívocos foram meramente de nomenclatura: exemplo disso foram as expressões "balanço de resultado econômico", "técnico em ciências contábeis" ou "previsão" no lugar de provisão. Outros afetam a própria essência da escrituração, como a forma de contabilização da depreciação (supostamente em fundo de reserva para garantir a reposição do bem depreciado), ou a limitação referente ao ativo diferido em relação aos gastos da fase pré-operacional, ou ainda a manutenção da antiga demonstração de lucros e perdas.

A escrituração das microempresas e empresas de pequeno porte passou por diversas fases em nossa legislação, que ora a dispensou de ter escrita mercantil, ora a exigiu. Paralelamente a isso, a legislação fiscal de regência também se imiscuiu na matéria comercial, fazendo com que alguns juristas, após a edição do novo Código Civil, remetessem seu regime de escrituração puramente à disciplina da legislação tributária. A própria legislação comercial (caso da Lei n. 11.101/05) fez concessões à legislação fiscal, ao remeter a disciplina da escrituração a ser apresentada no juízo falimentar por tal tipo empresarial à sua regulamentação própria, como bem observado pela Prof ${ }^{a}$. Rachel Sztajn.

Foi observado no trabalho o que chamamos de conseqüência ou efeito direto da escrituração: as demonstrações contábeis (ou financeiras), que nada mais são que relatórios, com fins específicos, retirados do todo maior escriturado. Algumas demonstrações contábeis ainda não são exigidas pela nossa legislação, nem mesmo pela 
Lei n. 6.404/76. Exemplo disso é a demonstração de fluxos de caixa (DFC) e a demonstração de valor adicionado (DVA).

A correção monetária das demonstrações, hoje extinta por efeito da Lei n. 9.249/95, é mecanismo importantíssimo para evitar distorções interpretativas e erros na tomada de decisões. Muito embora muitos aleguem que a estabilidade monetária vivida pelo país nos últimos anos torne a correção desnecessária, fato é que a inflação não foi de todo eliminada. Desse modo, a comparação de números expressos nas demonstrações, entre exercícios diferentes e sem a devida correção, pode gerar sérios problemas de análise pela diferença dos valores monetários no tempo.

Os efeitos ou repercussões da escrituração abrangem, hoje, muito mais do que a doutrina tradicional trazia (crimes falimentares, efeitos probatórios favoráveis e contrários dos livros, ou legitimação à concordata ou recuperação).

A escrituração, sua ausência ou irregularidade, influencia hoje a responsabilização civil profissional, as dissoluções societárias, o ingresso de uma determinada Companhia no segmento do Novo Mercado, além dos crimes tributários e contra o sistema financeiro. Perante as autoridades tributárias a escrituração pode gerar, conforme o caso, a imposição de multas e o arbitramento de tributos.

Por outro lado, ainda não há uma situação ideal para o combate aos erros, fraudes e até mesmo ao que se chamou no texto de "contabilidade criativa", nos dizeres do Prof. Ariovaldo dos Santos. A maior responsabilização dos auditores, a elaboração de regras de escrituração mais pormenorizadas e a harmonização dos conceitos, técnicas e princípios contábeis é uma necessidade para maior controle e equacionamento do problema. 


\section{BIBLIOGRAFIA}

ARNOLDI, Paulo Roberto Colombo. Teoria Geral do Direito Comercial. São Paulo: Saraiva, 1998.

ASCARELLI, Tullio. Corso de Diritto Commerciale. Introduzione e teoria dell'impresa. Milão: Giuffrè, 1962.

BOBBIO, Norberto. Teoria do Ordenamento Jurídico. Brasília: Polis, 1989.

BRIGHAM, Eugene F. et al. Administração financeira: teoria e prática. São Paulo: Atlas, 2001.

BULGARELLI, Waldirio. Direito Comercial. São Paulo: Atlas, 1991.

CARVAlHOSA, Modesto; LATORRACA, Nilton. Comentários à lei de sociedades anônimas. São Paulo: Saraiva, 1998, v. 2 e 3.

COELHO, Fábio Ulhoa. Código Comercial e Legislação Complementar anotados. São Paulo: Saraiva, 2003.

v. 1. Curso de Direito Comercial. São Paulo: Saraiva, 2003. Curso de Direito Comercial. São Paulo: Saraiva, 2003.

v. 2 . Curso de Direito Comercial. São Paulo: Saraiva, 2003.

v. 3 . Manual de Direito Comercial. São Paulo: Saraiva, 2003. - Comentários à Lei de Falências e Recuperação de empresas. São Paulo: Saraiva, 2005.

SOUZA JÚNIOR, Francisco Satiro de e PITOMBO, Antônio Sérgio A. de Moraes (coords.). Comentários à Lei de recuperação de empresas e falência: Lei 11.101/2005. São Paulo: Editora Revista dos Tribunais, 2005.

COMPARATO, Fábio Konder. Natureza jurídica do balanço. Ensaios e pareceres de direito empresarial. Rio de Janeiro: Forense, 1978, p. 29.

DELOITTE. Normas internacionais de contabilidade. São Paulo: Atlas, 2006.

FABRETTI, Láudio Camargo. Contabilidade tributária. São Paulo: Atlas, 2005.

FUNDAÇÃO Instituto de Pesquisas Contábeis, Atuariais e Financeiras. Aprendendo contabilidade em moeda constante. São Paulo: Atlas, 2004.

GITMAN, Lawrence J. Princípios de administração financeira. São Paulo: Harbra, 1997. 
GOMES, Orlando. Introdução ao Direito Civil. Rio de Janeiro: Forense, 1990.

IUDÍCIBUS, Sérgio de, et al. Contabilidade introdutória. São Paulo: Atlas, 1990. . Teoria da Contabilidade. São Paulo: Atlas, 2000.

IUDÍCIBUS, Sérgio de; MARTINS, Eliseu; GELBCKE, Ernesto Rubens. Manual de contabilidade das sociedades por ações. São Paulo: Atlas, 2003.

LACERDA, J. C. Sampaio de. Manual de Direito Falimentar. Rio de Janeiro: Freitas Bastos, 1978.

LOPES, Alexsandro Broedel; MARTINS, Eliseu. Teoria da Contabilidade: uma nova abordagem. São Paulo: Atlas, 2005.

MARION, José Carlos. Contabilidade básica. São Paulo: Atlas, 2004. .Contabilidade empresarial. São Paulo: Atlas, 1997.

MARTINS, Eliseu. Atrocidades contábeis no novo Código Civil. Boletim IOBThomson, São Paulo, n. 41, ano 2002, partes 1 e 2.

MARTINS, Fran. Curso de Direito Comercial. Rio de Janeiro: Forense, 1990. . Comentários à lei das sociedades anônimas. Rio de Janeiro:

Forense, 1984.

MAXIMILIANO, Carlos. Hermenêutica e aplicação do direito. Rio de Janeiro: Forense, 2001.

MELLO, Marcos Bernardes de. Teoria do fato jurídico: plano da existência. São Paulo: Saraiva, 1995.

MENDONÇA, José Xavier Carvalho de. Dos livros dos comerciantes. São Paulo: Rothschild, 1906.

.Tratado de Direito Comercial Brasileiro. São Paulo: Freitas

Bastos, 1960.

MIRANDA, Pontes de. Tratado de Direito Privado. São Paulo: Revista dos Tribunais, 1983. t. L.

NETO, Alexandre Assaf. Finanças corporativas e valor. São Paulo: Atlas, 2007.

NETO, Alfredo Sérgio Lazzareschi. Lei das sociedades por ações anotada. São Paulo: Atlas, 2006.

NEVES, Silvério das; VICECONTI, Paulo Eduardo Vilchez. Contabilidade de custos: um enfoque direto e objetivo. São Paulo: Frase, 2000. 
financeiras. São Paulo: Frase, 1999.

Contabilidade avançada e análise das demonstrações

NOVO DICIONÁRIO Aurélio da Língua Portuguesa. Curitiba: Editora Positivo. 1 CD-ROM.

PACCEZ, João Domiracci. Contabilidade Intermediária: exercícios. Faculdade de Economia, Administração e Contabilidade da Universidade de São Paulo (FEA-USP), 2005.

PACCIOLI, Luca. Summa de arithmetica, geometria, proportioni et proportionalità, Veneza, 1494.

PENTEADO, Mauro Rodrigues. Dissolução e liquidação de sociedades. São Paulo: Saraiva, 2000.

POVOA, Alexandre. Valuation. Como precificar ações. São Paulo: Globo, 2004.

RASHAD, A.; KHALIK, Abdel. Dicionário enciclopédico de contabilidade. São Paulo: Atlas, 2004.

REQUIÃO, Rubens. Curso de Direito Comercial. São Paulo: Saraiva, 1991. . Curso de Direito Falimentar. São Paulo: Saraiva, 1992.

RIBEIRO, Osni Moura. Contabilidade avançada. São Paulo: Saraiva, 2005. . Contabilidade intermediária. São Paulo: Saraiva, 2005.

SÁ, Antônio Lopes de. Planos de Contas. São Paulo: Atlas, 1998.

SÁ, Antônio Lopes de; HOOG, Wilson Alberto Zappa. Corrupção, fraude e contabilidade. Curitiba: Juruá, 2005.

SANTOS, Ariovaldo dos. Demonstração do Valor Adicionado: como elaborar e analisar a DVA. São Paulo: Atlas, 2003.

SANTOS, Ariovaldo dos; GRATERON, Ivan Ricardo Guevara. Contabilidade Criativa e responsabilidade dos auditores. Revista Contabilidade \& Finanças USP, São Paulo, n. 32, p. 7-22, maio/ago. 2003.

SANTOS, José Luiz dos; SCHIMIT, Paulo. Fundamentos de Contabilidade Societária. São Paulo: Atlas, 2005.

SÃO PAULO. Junta Comercial do Estado de São Paulo. Disponível em < http://www.jucesp.sp.gov.br/livros.htm>. Acesso em 26 mar. 2006.

VALVERDE, Trajano de Miranda. Comentários à lei de falências. Rio de Janeiro: Forense, 1962. 
VERÇOSA, Haroldo Malheiros Duclerc. Curso de Direito Comercial. São Paulo: Malheiros, 2004, v. 1 e 2. 